Faculdade de Arquitetura e Urbanismo da Universidade de São Paulo Programa de Pós-Graduação em Arquitetura e Urbanismo

Parâmetros de projeto para segurança contra incêndio do sistema construtivo em Cross Laminated Timber (CLT)

Patrícia Meira de Alcântara Costa Felix

São Paulo

2020 



\section{Parâmetros de projeto para segurança contra o incêndio do sistema construtivo em Cross Laminated Timber (CLT)}

Dissertação apresentada ao Programa de Pós-Graduação da Faculdade de Arquitetura e Urbanismo da Universidade de São Paulo (USP) para a obtenção do título de Mestre em Arquitetura.

Exemplar revisado e alterado em relação à versão original, sob responsabilidade do(a) autor(a) e anuência do(a) orientador(a).

A versão original, em formato digital, ficará arquivada na Biblioteca da Faculdade.

Aluna: Patrícia Meira de Alcântara Costa Felix

Orientadora: Prof. Dr ${ }^{\mathrm{a}}$. Rosaria Ono

Coorientadora: Prof. Dra ${ }^{\mathrm{a}}$. Fabiana Lopes de Oliveira 
Autorizo a reprodução e divulgação total ou parcial deste trabalho, por qualquer meio convencional ou eletrônico, para fins de estudo e pesquisa, desde que citada a fonte.

Catalogação na Publicação

Serviço Técnico de Biblioteca

Faculdade de Arquitetura e Urbanismo da Universidade de São Paulo

Felix, Patricia Meira de Alcintara Conta

Parametroe de projeto para eegurança contra o incendio do uistem construtivo em Croms Laminated Timber (CLT) /

Patricia Meira de Alcfintara Conta Pelix; orientador Roenaria Ono. coorientador Pabiana Oliveira - Säo Paulo, 2020.

199.

Dienertaç̄o (Meatrado) - Paculdade de Arquitetura e Urbaniamo da Univeraidade de Săo Paulo. Área de concentraç̄̃o: Tecnologia da Arquitetura.

1. Croes Laminated Timber. 2. Segurança Contra Incendio. 3. Projeto. I. Ono, Rosaria, orient. II. Oliveira, Fabiana, coorient. III. Titulo.

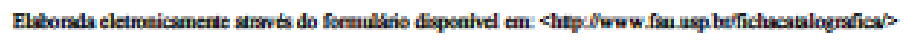





\section{DEDICATÓRIA}

"Dedico este trabalho a meu querido esposo Cleber, aos meus queridos

filhos Gabriel e Isabella e a toda minha família que, com muito carinho, paciência, compreensão e ajuda não mediram esforços para que eu chegasse até esta etapa da minha vida." 



\section{AGRADECIMENTOS}

Acima de tudo agradeço a Deus por me ajudar a superar as dificuldades encontradas ao longo dessa trajetória.

Aos meus queridos pais Edio e Clara por todo incentivo, apoio, cuidados e tempo despendidos aos meus filhos para que eu pudesse cumprir e concluir minhas atividades acadêmicas.

Também agradeço meus sogros Silvio e Marineide pela disposição, prontidão e atenção sempre que necessário.

A Profa. Dra ${ }^{\mathrm{a}}$. Rosaria Ono, pela orientação, disponibilidade de seu precioso tempo e condução para a conclusão deste trabalho.

A Profa ${ }^{a}$. Dra. Fabiana Oliveira Lopes, por me receber espontaneamente, seu grande desprendimento em ajudar e pela orientação que me guiaram para o desenvolvimento desta pesquisa.

Aos amigos, estudantes e pesquisadores pela ajuda com o fornecimento de publicações e informações que contribuíram para este trabalho.

Agradeço à equipe do Laboratório de madeiras e estruturas de madeira (LaMEM) pela ajuda e tempo cedidos.

Agradeço ao arquiteto André Augusto Hauser Castilho e sua equipe pela gentileza em ceder material, detalhes e informações técnicas essenciais para a realização deste trabalho.

Ao Sr. Alberto pela disponibilização do material necessário para as pesquisas técnicas.

À Coordenação de Aperfeiçoamento de Pessoal de Nível Superior (Capes), pela concessão da bolsa de mestrado e pelo apoio financeiro para a realização desta pesquisa. 



\section{EPÍGRAFE}

"[...] projetar exige a formação de juízos e a tomada de decisões ponderadas, muitas vezes num contexto moral e ético".

Bryan Lawson (2006) 


\section{RESUMO}

FELIX, Patrícia Meira de Alcântara Costa. Parâmetros de projeto para segurança contra o incêndio do sistema construtivo em Cross Laminated Timber (CLT). 2020.199 p. Dissertação (Mestrado) - Faculdade de Arquitetura e Urbanismo, Universidade de São Paulo, São Paulo, 2020.

Novas tecnologias na construção civil, têm contribuído para a introdução de sistemas construtivos industrializados inovadores. Um exemplo de sistema construtivo inovador é o Cross Laminated Timber - CLT ou Madeira Laminada Colada Cruzada (MLCC). Os painéis de CLT são constituídos usualmente por números ímpares a partir de três camadas de lamelas de madeira coladas com adesivos dispostas em direções ortogonais. No Brasil, já se tem exemplos de construções que adotaram este sistema. Porém, o uso da madeira na construção civil ainda encontra algumas barreiras culturais e técnicas, principalmente no Brasil, enquanto em países como Austrália, Reino Unido e Estados Unidos é amplamente difundido. Estes países têm normas regulamentadoras e técnicas baseadas em desempenho que possibilitam soluções alternativas, como a adoção de métodos construtivos inovadores, para agregar maior funcionalidade, qualidade e segurança. No Brasil a norma de desempenho ABNT NBR 15575:2013 - Edificações habitacionais, associado ao Sistema Nacional de Avaliação Técnica (SiNAT), veio cumprir este papel. O comportamento do material e do sistema CLT, considerando a reação e a resistência ao fogo pode ser determinante para avaliar o desempenho do sistema construtivo e fator participante das decisões de projeto de segurança contra incêndio. O sistema construtivo em CLT fabricado no Brasil é considerado inovador, pois ainda não há uma norma técnica para sua avaliação e a comprovação do seu desempenho. Desta forma, o objetivo deste trabalho, com base numa ampla revisão bibliográfica, foi compreender as características do material CLT e dos componentes do sistema construtivo no que se refere às questões que afetam o seu comportamento ao fogo (reação e resistência ao fogo), assim como os requisitos de desempenho a serem atendidos, a fim de propor parâmetros para o projeto de segurança contra incêndio para este sistema construtivo, com foco nas edificações unifamiliares isoladas, geminadas ou sobrepostas até dois pavimentos.

Palavras chaves: CLT, madeira laminada colada cruzada, sistema construtivo, segurança contra incêndio, desempenho, habitação. 


\begin{abstract}
FELIX, Patrícia Meira de Alcântara Costa. Design parameters for fire safety in Cross Laminated Timber (CLT) building assembly. 2020.199 p. Dissertação (Mestrado) - Faculdade de Arquitetura e Urbanismo, Universidade de São Paulo, São Paulo, 2020.
\end{abstract}

New technologies in civil construction have contributed to the introduction of innovative industrialized construction systems. An example of an innovative construction system is the Cross Laminated Timber - CLT. The CLT panels are usually made up of odd numbers from three layers of wooden lamellae glued with adhesives arranged in orthogonal directions. In Brazil, there are already examples of constructions that adopted this system. However, the use of wood in civil construction still encounters some cultural and technical barriers, mainly in Brazil, while in countries like Australia, the United Kingdom and the United States it is widespread. These countries have regulatory standards and performance-based techniques that enable alternative solutions, such as the adoption of innovative construction methods, to add greater functionality, quality and safety. In Brazil, the ABNT NBR 15575: 2013 performance standard - Residential buildings, associated with the National Technical Assessment System (SiNAT), came to fulfill this role. The behavior of the material and the CLT system, considering the reaction and resistance to fire can be determinant to evaluate the performance of the construction system and a participant factor in fire safety design decisions. The construction system in CLT manufactured in Brazil is considered innovative, as there is still no technical standard for its evaluation and proof of its performance. Thus, the objective of this work, based on a wide bibliographic review, was to understand the characteristics of the CLT material and the components of the construction system with regard to issues that affect its behavior to fire (reaction and fire resistance), as well as well as the performance requirements to be met, in order to propose parameters for the fire safety project for this construction system, with a focus on single-family buildings isolated, twinned or overlapping up to two floors.

Key words: CLT, cross-glued laminated wood, construction system, fire safety, performance, housing. 



\section{LISTA DE FIGURAS}

Figura 1 - Exemplos de sistemas construtivos de madeira................................ 32

Figura 2 - Os dois métodos utilizados para o sistema wood framing .................... 32

Figura 3 - Produtos de madeira engenheirada ………..................................... 34

Figura 4 - Stadhaus -Murray Grove (2009) - edifício residencial construído em CLT-

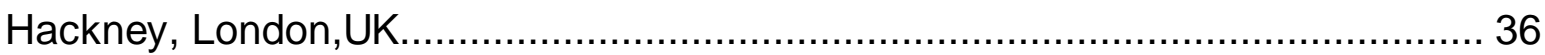

Figura 5 - The International House by Tzannes Architects - Centro comercial-

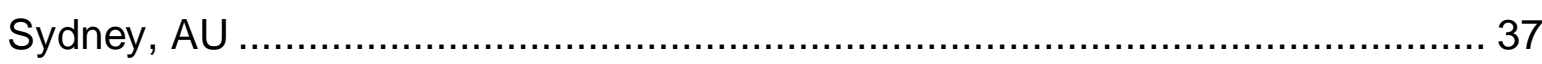

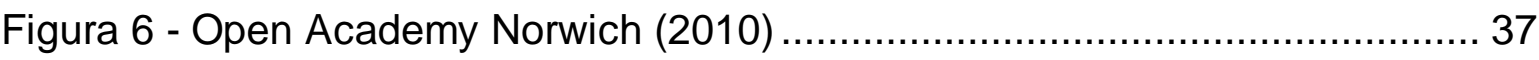

Figura 7 - Edifício WIDC (2014) de 29,5m de altura com 8 pavimentos construído em CLT, Prince George, BC - Canadá........................................................... 37

Figura 8 - Maior edificação a ser construída em CLT Stadium Drive Residence Halls em Portland, Oregon-U.S.A. Área construída aproximada de 19.000 m2, término da

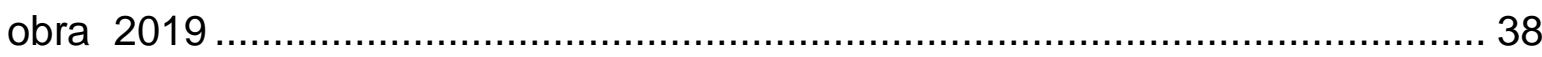

Figura 9 - Edfício residencial Forté Living, 32,2m de altura - Melbourne, Austrália 38

Figura 10 - Casa Tiradentes - Tiradentes-MG projetada pelo arquiteto Alexandre Veneziano, residência de um dormitório $\left(62 \mathrm{~m}^{2}\right)$. Estrutura em CLT executada em 2012 em três dias. 39

Figura 11 - Diagrama de disposição das camadas no painel CLT (laje) 41

Figura 12 - Composição do painel a) lamela; b) finger joint; c) painel de 03 camadas;

d) large finger joint 43

Figura 13 - Acesso para o descarregamento dos painéis 47

Figura 14 - Elevação e posicionamento dos painéis 
Figura 15 - Obra de residência unifamiliar construída em painéis de CLT, wood framing e vigas e pilares metálicos.

Figura 16 - Tipos de base para a instalação do painel 48

Figura 17 - Esboço da planta para posicionar os conectores. 50

Figura 18 - Exemplos das posições dos parafusos para a fixação do painel 50

Figura 19 - Fixação: a) suporte angular (canto) com parafusos tipo SKR (1) ou SKS (2); b) com parafuso de rosca completa VGZ 51

Figura 20 - Sequência da proteção do painel até o acabamento externo 51

Figura 21 - Ranhuras para passagem da tubulação elétrica. 53

Figura 22 - Instalações hidrossanitárias e fechamentos em placas de gesso e revestimento cerâmicos 53

Figura 23 - Etapas da montagem dos painéis 54

Figura 24 - Evolução do incêndio na edificação ………………….................... 56

Figura 25 - Seção carbonizada da madeira. 62

Figura 26 - Espessura de carbonização dchar,o e espessura carbonização nominal $\mathrm{d}_{\text {char, } \mathrm{n}}$ (efeito do arredondamento de canto)....... 68

Figura 27 - Taxa de carbonização para elementos não protegidos e protegidos com falha na proteção 70

Figura 28 - Falha da resistência 73

Figura 29 - Construção de paredes de compartimentação 80

Figura 30 - Edificações de diferentes alturas 82

Figura 31 - Distribuição de iluminação natural 83

Figura 32 - Junção da parede de compartimentação com a cobertura 89

Figura 33 - Disposição das barreiras entre elementos e/ou componentes. 90

Figura 34 - Proteção contra fogo em tubulações 
Figura 35 - Cálculo da área para paredes com revestimento combustível. .92

Figura 36 - Áreas não protegidas que podem ser desconsideradas para o cálculo da distância de separação a partir do limite 92

Figura 37 - Distância das estruturas de proteção de aberturas ........................... 93

Figura 38 - Áreas desprotegidas permitidas para edificações até $24 \mathrm{~m}$ de altura.. 93

Figura 39 - Limites do lote 94

Figura 40 - Limite teórico... 95

Figura 41 - Requisitos para paredes e superfícies externas 95

Figura - 42 Incêndios por tipo de ocupação 105

Figura 43 - Método da seção transversal para o CLT 129

Figura 44 - Comportamento da carbonização entre junções do painel a) junção tipo degrau e b) junção de canto 139

Figura 45 - Ensaio de fogo com elastômeros absorvedores de vibração na interface da parede e piso a) sem carbonização na lateral do elemento junto ao elastômero; b) sem carbonização do elastômero na junção entre piso e parede. 140

Figura 46 - Propagação de chamas entre as cavidades formadas pelas junções do sistema construtivo de CLT 146

Figura 47 - Detalhe do painel de compartimentação entre pisos 151

Figura 48 - Detalhe do painel da fachada entre pisos 152

Figura 49 - Detalhe do painel de compartimentação para varandas 153

Figura 50 - Detalhe do elemento de compartimentação vertitcal 154

Figura 51 - Distâncias mínimas para a resistência do painel entre aberturas ..... 155

Figura 52 - Detalhe da cobertura com isolamento....................................... 156

Figura 53 - Sistemas de material intumescente passivo e ativo 158 
Figura 54 - Revestimento de proteção ao fogo emoldurando a área para a passagem das instalações. 158

Figura 55 - Selagem da tubulação metálica no elemento de CLT 159

Figura 56 - Exemplos para as instalações elétrica embutidas no elemento de CLT 160

Figura 57 - Aplicação de material intumescente para aumento da resistência ao fogo e carbonização do canal da passagem das instalações e da borda do painel.... 160

Figura 58 - Camada adicional para a instalação de tomadas e interruptores...... 161

Figura 59 - Revestimento do canal no painel para a passagem de instalações.. 161 Figura 60 - Instalação elétrica revestida com material isolante como lã de rocha e calafetada com compostos intumescentes em toda espessura do elemento 161

Figura 61 - Elementos de madeira protegidos por placas de gesso acartonado Exemplos de comprimento de penetração do fixador na madeira não carbonizada 165

Figura 62 - Bloco do estúdio de hóspedes 169

Figura 63 - Implantação da edificação em Valinhos, SP 169

Figura 64 - Planta do estúdio de hóspedes e garagem 170

Figura 65 - Cortes longitudinal e transversal do estúdio de hóspedes 171

Figura 66 - Fundação do bloco do estúdio de hóspedes 172

Figura 67 - Esquema dos painéis de CLT do estúdio de hóspedes 173

Figura 68 - Esquema dos painéis de CLT da garagem 173

Figura 69 - Perspectiva dos painéis de CLT do estúdio de hóspedes. 174

Figura 70 - Perspectiva dos painéis de CLT da garagem 174 
Figura 71 - Exemplos de fixação dos painéis de CLT fotos superior direita e esquerda parafuso VGZ, fotos inferior esquerda cantoneira e da direita chapa reta 175

Figura 72 - Modelo da fachada dos blocos com o sistema EIFS....................... 177

Figura 73 - Exemplo de fachada com madeira termotratada .............................177

Figura 74 - Laje de cobertura antes da proteção com manta .............................. 178

Figura 75 - Laje de cobertura com manta impermeável .................................. 178

Figura 76- Vigas metálicas para evitar a flexão da laje de piso........................... 179

Figura 77 - Canaletas usinadas na fábrica para a instalação de serviços........... 179

Figura 78 - Lamelas dispostas na direção da carga (contra verga) .................... 180 


\section{LISTA DE TABELAS}

Tabela 01- Fases de degradação da madeira. 63

Tabela 02 - Taxa de carbonização $\beta_{0}$ e $\beta_{n}$ da madeira, LVL, revestimento e produtos derivados da madeira 69

Tabela 03 - Resistência dos elementos construtivos ......................................... 79

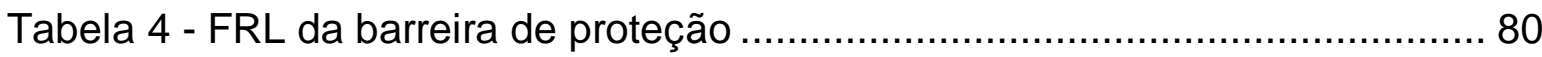

Tabela 5 - Distância entre paredes externas e aberturas associadas em diferentes compartimentos de incêndio 83

Tabela 6 - Classificação para os edifícios residenciais no Reino Unido ................ 87

Tabela 7 - Resistência ao fogo para edificações residenciais ............................. 87

Tabela 8 - Resistência ao fogo dos elementos construtivos................................ 88

Tabela 9 - Resumo dos requisitos BS EN 16351:2015 - Timber structures - Cross

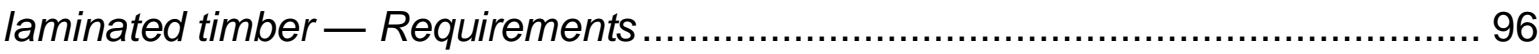

Tabela 10 - Alturas permitidas para os tipos de construção.................................. 99

Tabela 11 - Classificação de resistência ao fogo para materiais de construção. 100

Tabela 12 - Distância das edificações do Grupo R .......................................... 102

Tabela 13 - Classificação dos materiais que compõem as camadas do sistema de

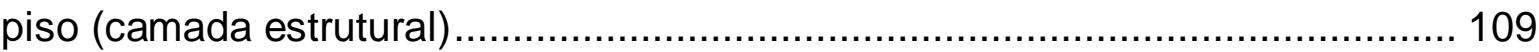

Tabela 14 - Classificação do sistema de piso (camada estrutural) como base em métodos de ensaios alternativos 110

Tabela 15 - Classificação de materiais com base no método ANBT NBR 9442:1986

Tabela 16 - Classificação dos materiais de cobertura acordo com o método alternativo EN 13823:2010 
Tabela 17 - Classificação dos materiais do sistema de cobertura tendo como base

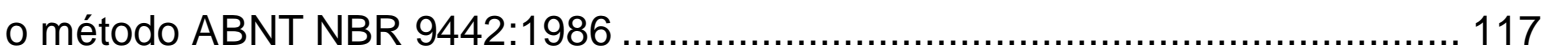

Tabela 18 - Resistência mínima dos diferentes tipos de fixadores.......................163 


\section{LISTA DE QUADROS}

Quadro 1 - Classificação das edificações residenciais....................................... 78

Quadro 2 - Resumo das exigências para segurança contra incêndio em edifícios residenciais unifamiliares, geminados ou sobrepostos 121

Quadro 3 - Requisitos de proteção ao fogo para sistemas construtivos de madeira 122

Quadro 4 - Requisitos de proteção ao fogo para sistemas construtivos em CLT..126

Quadro 5 - Resumo da proteção ao fogo para o CLT. 141

Quadro 6 - Resumo dos parâmetros de projeto para o CLT segundo os requisitos da ABNT NBR 15575:2003 166 


\section{SUMÁRIO}

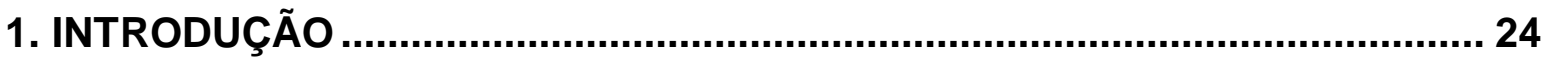

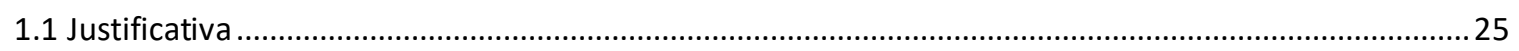

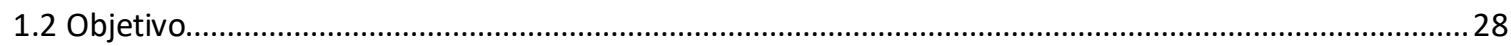

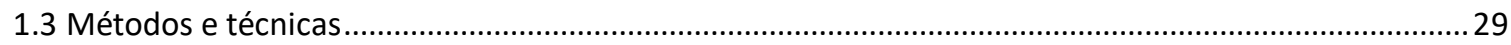

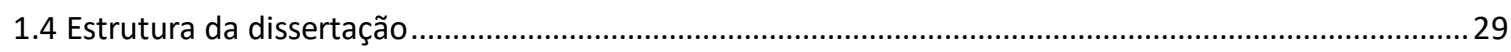

2. SISTEMAS CONSTRUTIVOS DE MADEIRA …............................................ 31

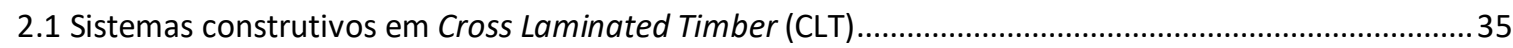

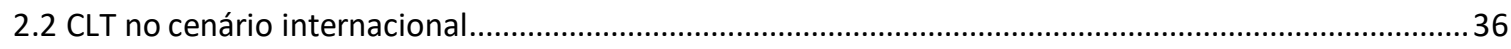

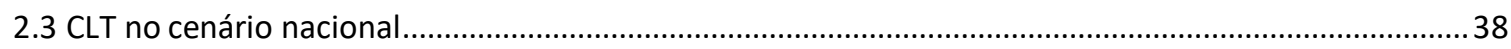

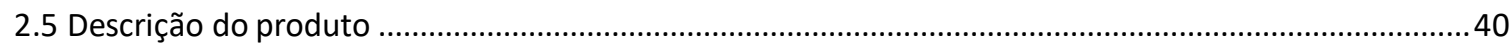

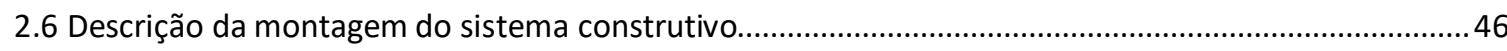

3. PARÂMETROS DA SEGURANÇA CONTRA INCÊNDIO ….............................55

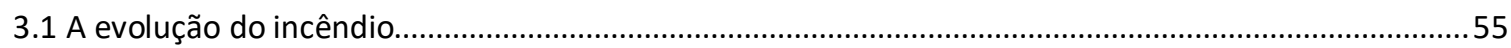

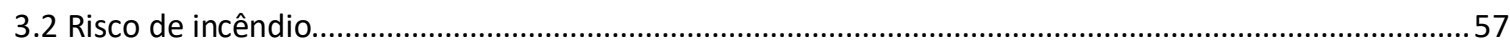

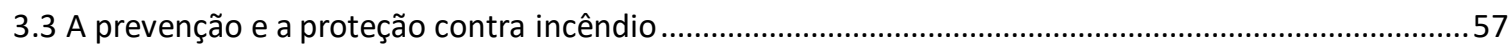

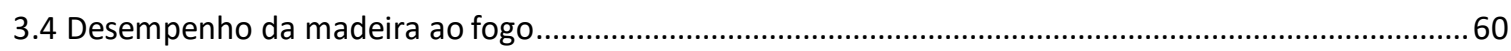

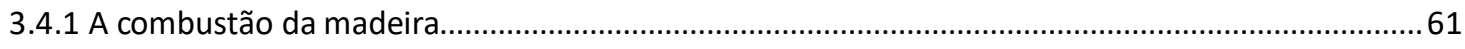

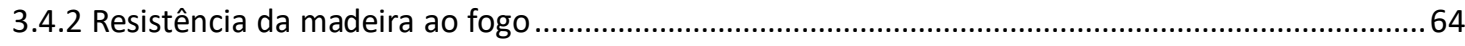

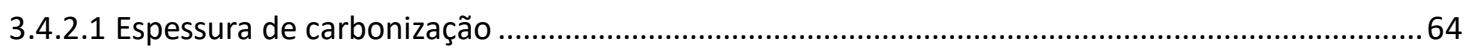

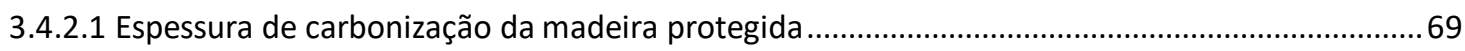

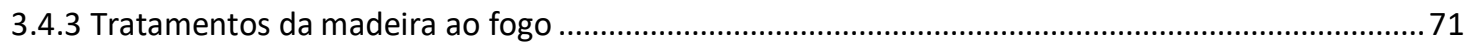

3.5 Projeto estrutural de madeira contra incêndio ............................................................................. 72 


\section{CÓDIGOS E NORMAS TÉCNICAS CONSTRUTIVAS VISANDO À SEGURANÇA CONTRA INCÊNDIO_................................................................ 75}

4.1 Requisitos gerais de segurança contra incêndio...................................................................................

4.2 Códigos construtivos e segurança contra incêndio ...............................................................................78

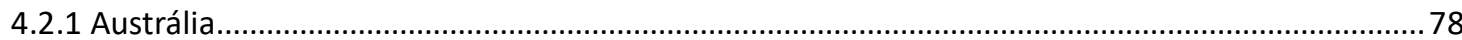

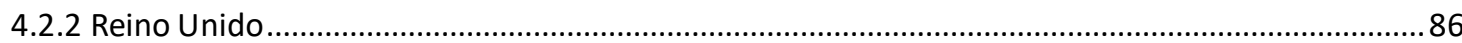

4.2.4 Estados Unidos da América ..................................................................................................... 98

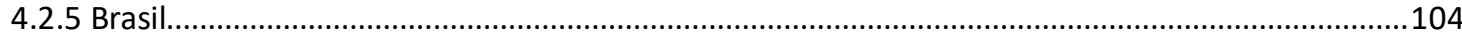

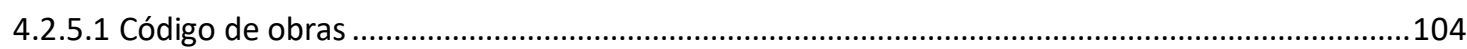

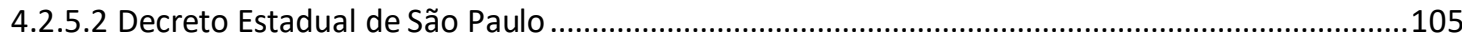

4.2.5.3 Instruções técnicas do Corpo de Bombeiros de SP ..................................................................106

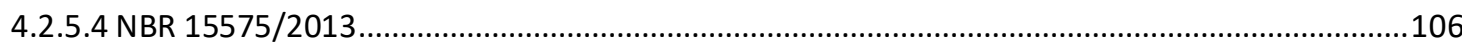

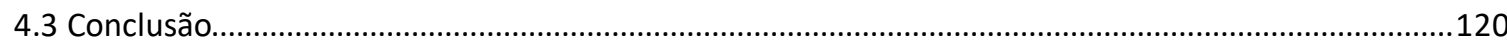

\section{O SISTEMA CROSS LAMINATED TIMBER (CLT) E A SEGURANÇA CONTRA INCÊNDIO}

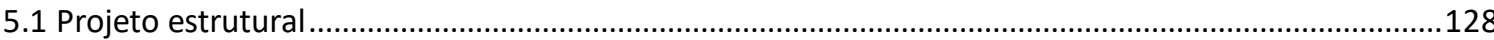

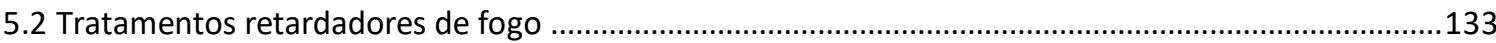

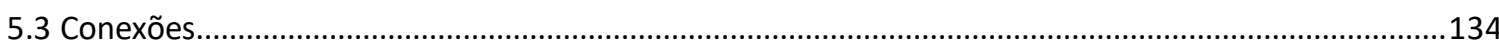

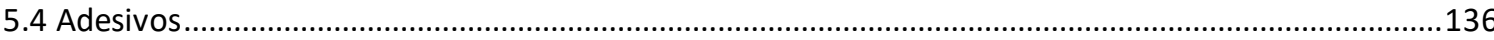

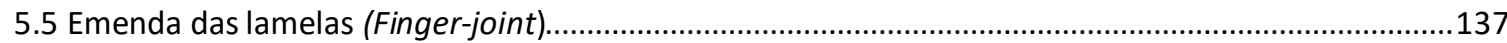

5.6 Junções

5.7 Parâmetros da segurança contra incêndio para edifícios residenciais isolados, geminados e em

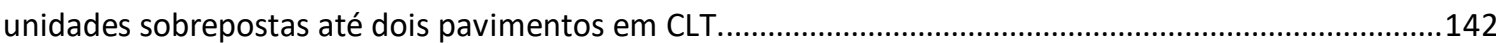

5.7.1 Dificultar o princípio de incêndio.....................................................................................................

5.7.2 Dificultar a inflamação generalizada ........................................................................................144

5.7.3 Dificultar a propagação de incêndio.........................................................................................145 
5.7.4.1. Resistência ao fogo dos elementos de compartimentação horizontal (pisos) entre pavimentos e elementos associados 151

5.7.4.2. Resistência ao fogo dos elementos estruturais de compartimentação vertical (SVVI) 154

5.7.4.3. Resistência ao fogo do sistema de cobertura 156

5.7.4.4. Selagem corta-fogo nas prumadas elétricas e hidráulicas 157

5.7.4.5. Prumadas verticais entre elementos de vedação horizontal (pisos). 162

5.7.4.6. Escadas, elevadores e monta-cargas 162

5.7.4.7. Resistência ao fogo de dispositivos de fixação e conexão 163

5.8 Projetos em sistema construtivo de CLT no Brasil 168

5.9 Recomendações para o projeto de segurança contra incêndio do sistema construtivo de CLT........184

6. CONSIDERAÇÕES FINAIS 188

6.1 Sugestões para pesquisas futuras 189

6.2 Conclusão 190 


\section{INTRODUÇÃO}

A conscientização ambiental e a introdução de conceitos de sustentabilidade na construção têm incentivado o uso da madeira plantada, principalmente com o intuito de reduzir o impacto de emissões de gases efeito estufa, nocivos ao meio ambiente, produzidos pelo setor da construção civil. A madeira é um dos poucos materiais empregados na construção civil de fonte inteiramente renovável (desde que não seja usado nenhum produto ou tratamento químico). Segundo Passarelli (2013), quando o manejo florestal é feito com técnicas apropriadas pode-se estender a exploração do recurso madeireiro por tempo indeterminado.

Hoje, o Brasil é, de acordo com informações divulgadas pelo Sistema Nacional de Informações Florestais - SNIF, integrado ao Sistema Nacional de Informações sobre o Meio Ambiente - SINIMA, o único país que possui extensa área de florestas tropicais e tem a segunda maior cobertura florestal do mundo, perdendo apenas para a Rússia. Segundo a estimativa do SNIF 69\% do território nacional é coberto por florestas (BRASIL, 2017a). Entretanto apenas 1\% desta cobertura vegetal é de árvores plantadas e sendo a maior parte destinada a indústria de papel, celulose e metalúrgica. $O$ aprimoramento técnico e incentivos econômicos poderiam potencializar o emprego de madeira plantada na construção civil e assim a aumentar a oferta de matéria-prima reduzindo o preço dos produtos derivados da madeira e com custo atrativo economicamente para o setor da construção civil.

O déficit habitacional no país também contribui para a busca de novos métodos construtivos que visam a redução de custos e agilidade na construção, a fim de diminuir a demanda por habitações, principalmente edifícios de habitação social.

No entanto, o problema não se caracteriza apenas como uma questão quantitativa, mas também, qualitativa, pois é fundamental que as moradias produzidas passem por um rigoroso controle de qualidade durante o projeto e a construção, visando minimizar as ocorrências de defeitos e manifestações patológicas e desempenho, que dependendo da escala de produção, possam ser replicados nas unidades (PASSARELLI, 2013). 
Outro fator importante a ser levado em conta para as edificações de madeira é a conscientização do usuário, pois ele deve estar ciente dos riscos e procedimentos a serem tomados, considerando que este tipo de edificação exige cuidados de manutenção diferentes da construção convencional (PINTO, 2001).

\subsection{Justificativa}

Vários fatores como a questão da durabilidade e a insegurança quanto ao uso da madeira dificultam o crescimento e o emprego de sistemas construtivos com esse material no Brasil. Isso ocorre também por falta de conhecimento técnico e a ausência de sistemas construtivos racionalizados e expressivos em nível nacional. A segurança contra o incêndio é outro fator que limita o uso da madeira na construção civil.

A madeira, além de ser um material renovável, também apresenta diversas propriedades como alta resistência específica, boas características de isolamento térmico e elétrico, boa trabalhabilidade manual e mecânica e baixo consumo no seu processamento, tornando-se um material atrativo em comparação a outros materiais (ZENID, 2002).

No entanto, a madeira por ser um material combustível, transmite a falsa ideia de que permite um crescimento mais rápido do fogo, prejudicando a segurança estrutural do sistema que entraria rapidamente em colapso aumentando o risco de vida dos ocupantes. Por isso, é muito importante associar a necessidade de mais pesquisas voltadas à proteção dos sistemas construtivos em madeira contra a ação do fogo e difundir essa informação amplamente, para comprovar que são tecnicamente viáveis (PINTO, 2001).

Ao contrário do que muitos pensam, a madeira apresenta bom desempenho contra o incêndio quando comparada a outros materiais estruturais. As peças robustas e maciças, quando expostas à ação das chamas, formam uma camada de carvão isolante que dificulta a saída de gases inflamáveis e a penetração de calor para seu interior, o que justifica sua capacidade em manter a sustentação estrutural mesmo após terem sido expostas a altas temperaturas. 
As construções em madeira podem ser projetadas para ter resistência ao fogo e controle de sua expansão, resultando em estruturas resistentes ao colapso (BUCHANAN, 1999). Por isso, é muito importante que na fase do projeto a abordagem básica da segurança contra o incêndio seja estabelecida, pois esse é um objetivo a ser perseguido durante todas as etapas envolvidas no processo de projeto, produção e no uso do edifício e nenhuma etapa deve ser menosprezada (BERTO, 1991).

Segundo Pinto (2001), a madeira quando submetida às chamas tem carbonização periférica e essa camada superficial de carão age como uma espécie de isolante, impedindo a rápida saída de gases inflamáveis e a propagação de calor para o interior da seção, resultando em uma velocidade menor de degradação, e assim, aumentando o tempo da capacidade de sustentação das cargas da edificação até a perda da capacidade de resistência.

As propriedades térmicas e as relacionadas à resistência e rigidez são as que mais influenciam no desempenho da madeira exposta ao fogo. A maioria destas propriedades está relacionada a fatores próprios da madeira, como a densidade, o teor de umidade, a orientação da grã (isto é, a disposição geral das células da madeira em relação ao eixo da peça estrutural), a composição química, a permeabilidade, a condutividade térmica e fatores externos como as temperaturas de exposição ao fogo, duração da exposição e a ventilação no ambiente (PINTO, 2001).

Com o conhecimento de todas essas características do material e das diretrizes projetuais que asseguram a segurança contra o incêndio, é possível projetar edificações de madeira que garantam a segurança à vida dos usuários.

A madeira como material estrutural é uma opção que está adquirindo relevância crescente no mundo. Porém, no Brasil, os sistemas construtivos existentes em madeira normalmente carecem de tecnologia e maiores especificações para sua segurança ao fogo. Por exemplo, a atual norma que trata de projeto de estrutura em madeiras, ABNT NBR 7190: Projeto de estruturas de madeira (ASSOCIAÇÃO BRASILEIRA DE NORMAS TÉCNICAS, 1997), não trata 
da questão, não aborda esse requisito, embora o seu texto esteja em revisão atualmente.

De acordo com Fontana, Favre e Fetz (1999), em edificações modernas de madeiras, construídas dentro do estado-da-arte da compartimentação ou com sistemas de proteção ativos, não ocorrem grandes perdas devido ao incêndio. Contudo, além das orientações contidas nas Instruções Técnicas do referencial normativo e legal dos corpos de bombeiros estaduais, e a ABNT NBR 15575: Edificações habitacionais - Desempenho - Partes 1- 6 (ASSOCIAÇÃO BRASILEIRA DE NORMAS TÉCNICAS, 2013 a), ainda precisam ser definidas normas brasileiras mais específicas para os sistemas construtivos inovadores em madeira.

Dentre os sistemas construtivos de madeira, o Cross Laminated Timber (CLT) vem ganhando cada vez mais destaque no cenário mundial, pois o painel com capacidade estrutural tem permitido a construção de edificações acima de quatro pavimentos. O CLT, no Brasil há menos de dez anos ainda de forma incipiente, vem aos poucos sendo introduzido no mercado nacional. O sistema vem sendo empregado principalmente para edificações residenciais unifamiliares.

Como sistema inovador no país, o CLT precisa passar por uma ampla avaliação pelos padrões técnicos de desempenho para que sua utilização se torne racional e segura.

Neste sentido, esta pesquisa foi desenvolvida com base em uma extensa revisão bibliográfica sobre a problemática do fogo nas estruturas de madeira e nas soluções construtivas adotadas para garantir a segurança nas edificações habitacionais em situação de incêndio.

Como resultado desta pesquisa foram apresentados critérios, dados, detalhes técnicos executivos que servirão de parâmetros de projeto para o sistema construtivo em CLT, visando garantir a exigência da segurança contra incêndio no que se refere ao seu desempenho à reação ao fogo dos materiais incorporados aos elementos construtivos, compartimentação horizontal e vertical, resistência ao fogo dos elementos estruturais e a estanqueidade ao fogo e à fumaça em situações de incêndio. No Brasil este sistema tem se introduzido principalmente por meio de 
edifícios residenciais unifamiliares e por isso esta pesquisa teve como objeto de estudo a seguinte tipologia: edifícios residenciais isolados térreos, assobradas, geminados ou unidades sobrepostas até dois pavimentos.

\subsection{Objetivo}

Culturalmente, há uma resistência ao uso da madeira como sistema construtivo, em parte, pelo desconhecimento do comportamento do material em relação ao fogo. $O$ crescimento do incêndio é fortemente dependente da arquitetura do edifício e dos materiais nele utilizados. As considerações das exigências de segurança ao fogo para um sistema construtivo inovador requerem uma visão global do projeto da edificação.

Para definir os principais objetivos desta pesquisa tomam-se como base as premissas abaixo relacionadas:

- Conhecimento das propriedades termo-físico-mecânicas da madeira exposta ao fogo;

- Conhecimento do estado-da-arte da atual da segurança contra incêndio no país;

- Parâmetros iniciais de projeto que consideram os requisitos da segurança contra incêndio para a adoção das soluções arquitetônicas; e

- Atendimento aos requisitos mínimos de segurança contra o incêndio das regulamentações e normas.

Pelo exposto, o presente trabalho tem por objetivo:

- Conhecer as particularidades dos materiais que compõem o sistema construtivo em CLT fabricado no Brasil;

- Verificar se o sistema construtivo em CLT no Brasil atende às exigências das normas técnicas aplicadas internacionalmente e se adequa aos requisitos das normas técnicas nacionais em relação à segurança contra incêndio;

- Sistematizar detalhes construtivos que contribuam para aumento da segurança contra incêndio no sistema construtivo em CLT;

- Definir parâmetros para o projeto de arquitetura no sistema construtivo em CLT para garantir a segurança contra o incêndio. 


\subsection{Métodos e técnicas}

Para atingir os objetivos acima descritos, a pesquisa seguiu a seguinte metodologia:

A parte teórica foi desenvolvida com base em revisão bibliográfica (nacional e internacional) sobre o comportamento e a proteção dos sistemas construtivos em madeira contra o fogo, assim como das normas técnicas nacionais e internacionais, códigos de obra e regulamentações municipais, estaduais e além de instruções técnicas do Corpo de Bombeiro do Estado de São Paulo, a partir de materiais publicados em livros, artigos, trabalhos acadêmicos, handbooks e normas, com abordagem da madeira exposta ao fogo, levantamento e análise dos regulamentos e normas para edificações residenciais com foco na segurança contra incêndio.

A parte prática foi desenvolvida no estudo de temas alusivos à utilização da madeira como sistema construtivo e na descrição do processo construtivo, caracterização dos componentes e levantamento de edificações internacionalmente e nacionais, para análise do sistema construtivo em CLT e suas particularidades no Brasil - como, por exemplo, tipo da madeira, tratamento, resinas, colas utilizadas, conexões, etc. que possam afetar a segurança ao fogo para a proposta de soluções. Além disso, foram definidos parâmetros de projeto para a segurança contra incêndio em edificações residenciais isoladas, assobradadas, geminadas ou unidades sobrepostas. E, por fim, realizou-se uma análise de um projeto residencial que adotou o sistema construtivo de CLT e sua relação com a segurança contra incêndio.

\subsection{Estrutura da dissertação}

O capítulo 1 dá um panorama geral do emprego da madeira na construção civil no Brasil e discute a questão da segurança ao fogo para edifícios construídos com esse material e introduz o sistema construtivo inovador CLT, além de justificar e definir os objetivos da dissertação.

O capítulo 2 apresenta alguns dos sistemas construtivos de madeira na história e a introdução de novos produtos derivados da madeira utilizados 
atualmente como o CLT e exemplos de edificações utilizando este sistema no cenário internacional e nacional, além de sua descrição e montagem.

No capítulo 3 tem como objetivo descrever os parâmetros de segurança contra incêndio e o desempenho da madeira ao fogo.

O capítulo 4 expõe os requisitos gerais de segurança contra incêndio utilizado por códigos e normas técnicas da Austrália, Reino Unido, Estados Unidos da América e no Brasil, voltados para edifícios residenciais isolados, assobradados, geminados ou unidades sobrepostas, com ênfase nos edifícios com sistemas construtivos de madeira.

Já o capítulo 5 aborda os requisitos de segurança contra incêndio e os parâmetros para definir os critérios e as recomendações de projeto para o sistema CLT concluindo com uma breve análise de um edifício na cidade de Valinhos em São Paulo construído em CLT para observar os potenciais riscos de incêndio. O capítulo 6 apresenta as considerações finais, a conclusão do resultado da pesquisa e sugestões para pesquisas futuras para avaliar e contribuir para uma definição futura das diretrizes para CLT quanto a segurança contra incêndio. 


\section{SISTEMAS CONSTRUTIVOS DE MADEIRA}

A madeira tem sido utilizada como material construtivo desde os primórdios da civilização. O clima, a topografia e os costumes culturais determinaram diferentes métodos construtivos em madeira para cada civilização. Algumas civilizações do Extremo Oriente produziram arquitetura de estrutura leve, feita para suportar os terremotos frequentes, portanto feita de encaixes simples, mas resistentes. $\mathrm{Na}$ Europa, a arquitetura Norueguesa é caracterizada pela massividade da espessura das paredes capazes de isolar o frio (BRANCO; LOURENÇO, 2012).

Nos finais da Idade Média e no Renascimento, em muitas civilizações, a destreza dos carpinteiros e artífices permitia construir edifícios de até cinco ou seis pavimentos. Muitos edifícios naquela época foram construídos em madeira e resistiram tanto ou mais que os construídos em pedra e tijolos (BRANCO; LOURENÇO, 2012).

$\mathrm{Na}$ Europa, a partir do século XV, com o desenvolvimento de técnicas de serragem, as construções em madeira com troncos de espécies arbóreas originadas de países do norte da Europa foram substituídas aos poucos por edificações constituídas de tábuas ou troncos de seção retangular, permitindo maior estabilidade às construções.

Naquele período os sistemas construtivos em madeira, denominados enxaimel e gaiola, construídos em estrutura de madeira com vedações em diversos materiais, como pedras, tijolos ou barro, foram amplamente utilizados por muitos povos europeus: eram sistemas simples, rápidos, econômicos e resistentes. Ao longo do tempo muitas destas estruturas evoluíram tecnicamente e surgiram novos métodos e tecnologias que hoje em dia são amplamente empregadas em vários países.

Atualmente, segundo Buchanan e Abu (2017), as estruturas de madeira podem ser divididas em três principais categorias: sistema viga-pilar, estruturas leves de madeira (Light timber frame ou Light wood frame na America do Norte) e estruturas em madeira pesada ou maciça (Heavy timber ou Massive wood) como mostra a Figura 1. 
Figura 1- Exemplos de sistemas construtivos de madeira

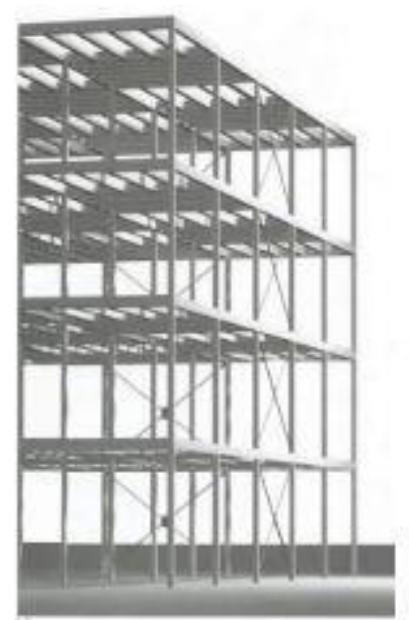

Viga-pilar

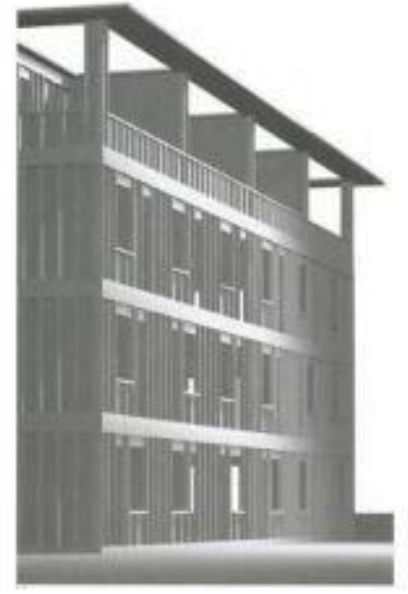

Light Frame

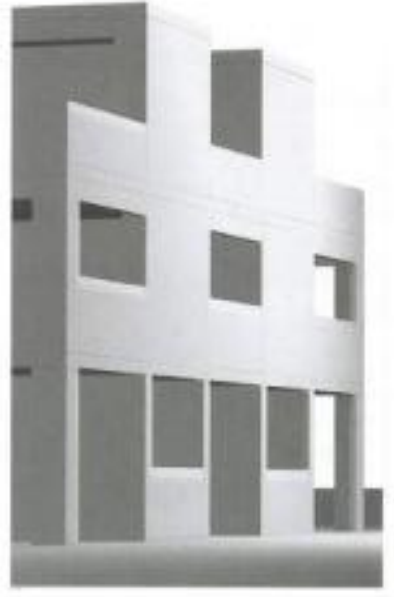

Massive wood

Fonte: Rethink wood (2018 imagem: Fast + Epp) tradução nossa

Figura 2- Os dois métodos utilizados para o sistema wood framing

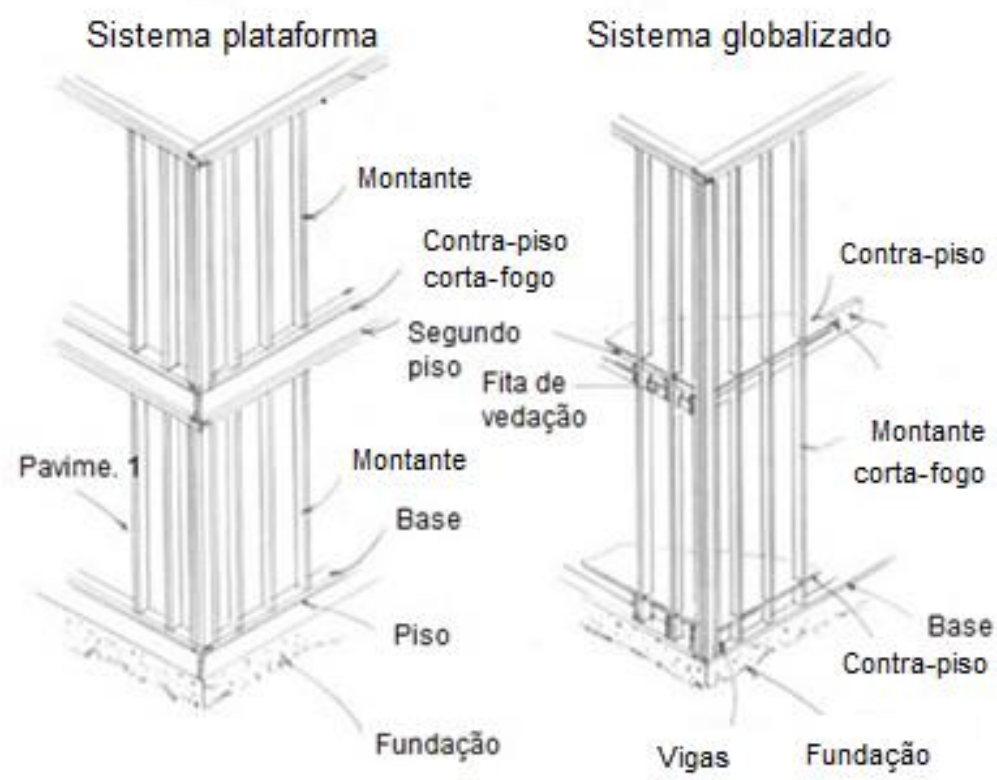

Fonte: SONIA (2018) tradução nossa 
O sistema viga-pilar é constituído por pilares e vigas que dispõem em forma de pórticos, sistema autoportante e independente de outros sistemas, como exemplo o sistema de vedação vertical, pois a distribuição de cargas é concentrada das vigas para os pilares e destes para a fundação. Este sistema foi muito utilizado no período colonial brasileiro e até hoje continua sendo empregado pela sua simplicidade construtiva, porém aprimorado devido aos cálculos estruturais das normas técnicas e desenvolvimento de novos produtos e madeira (VALLE, 2011).

Os sistemas de estruturas leves são constituídos de peças serradas de pequenas dimensões padronizadas e fixadas com parafusos com fechamento em chapas de gesso, cimentícias etc. Há duas versões: sistema plataforma e sistema globalizado (Figura 2). A categoria das estruturas em madeira pesada ou maciça é formada por elementos de grandes dimensões de madeira serrada e/ou produtos fabricados a partir de lâminas de madeira colados com adesivos, usando uma técnica de camadas, em que o resultado é um bloco único. O termo "Heavy Timber" (madeira pesada) é usado para descrever madeira serrada sólida que é de $140 \mathrm{~mm}$ (5-1 / 2 in) ou mais em sua menor dimensão de seção transversal (CWC, 2018).

Na América do Norte, nos seus códigos de segurança contra incêndio, os termos 'heavy timber construction'e 'mill construction' se aplicam às colunas e vigas com dimensão mínima de $150 \mathrm{~mm}$ e a pisos de espessura mínima de $50 \mathrm{~mm}$. Em outros países, os elementos de madeira pesada geralmente se referem a elementos com dimensões a partir de $80 \mathrm{~mm}$.

Porém nas últimas décadas, têm surgido novos produtos derivados de madeira, conhecidos como madeira engenheirada. Estes novos produtos pretendem solucionar as limitações naturais da madeira como, por exemplo:

a) A largura e o comprimento das peças que são limitadas ao diâmetro e altura das árvores;

b) As propriedades mecânicas e não mecânicas da madeira são distintas nas direções de crescimento tangencial, radial e longitudinal; e

c) Os defeitos naturais que interferem no comportamento reológico da madeira: nós, inclinação da grã, percentagem de lenhos juvenil e adultos, lenhos de reação, largura dos anéis de crescimento, etc. (REMADE, 2019). 
A madeira engenheirada é o resultado da aplicação de tecnologias e processos produtivos avançados, com uma criteriosa seleção da madeira, objetivando a eliminação dos defeitos naturais indesejáveis na matéria-prima e como consequência, obtém-se o aumento geral de seu desempenho (MARTINI, 2016).

De acordo com Branco e Lourenço (2012, p.78-81), estes novos produtos visam essencialmente à obtenção de elementos construtivos de alta resistência, baixa variação comportamental e alta tipificação dimensional, procurando uma normatização que permita a continuidade da crescente garantia de qualidade inerente aos produtos de madeira e derivados.

De forma semelhante à madeira serrada, os componentes estruturais de madeira, structural componentes lumber - SCL, são utilizados para aplicações estruturais como vigas, treliças, pilares como o glue laminated timber - glulam (madeira laminada colada - MLC ${ }^{1}$ ), laminated veener lumber - LVL (madeira micro laminada), parallel strand lumber - PSL, laminated strand lumber - LSL, oriented strand lumber - OSL e o cross laminated timber - CLT (Figura 3).

Figura 3 - Produtos de madeira engenheirada

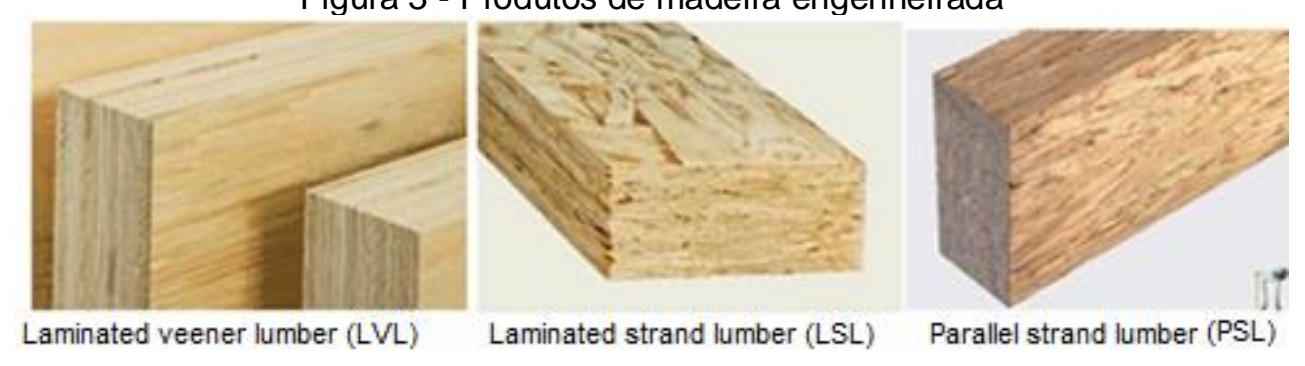

Fonte: CBI (2017)

Nesta pesquisa o termo utilizado para a categoria de estruturas de madeiras para o cross laminated timber (CLT) será Massive Wood, pois a maioria dos fabricantes destes painéis utiliza esta nomenclatura.

\footnotetext{
${ }^{1}$ Madeira lamelada ou laminada colada (MLC): Podem ser empregados os dois termos pois o produto final MLC é produzido a partir da técnica da colagem aliada à técnica da laminação, ou seja, da reconstituição da madeira a partir de lamelas (neste caso podem ser entendidas como tábuas) que são de dimensões relativamente reduzidas se comparadas às dimensões da peça final assim constituída. Essas lâminas, que são unidas por colagem, ficam dispostas de tal maneira que as suas fibras estejam paralelas entre si. http://www.carpinteria.com.br.Acesso 6/08/2018.
} 


\subsection{Sistemas construtivos em Cross Laminated Timber (CLT)}

O CLT, também conhecido como madeira lamelada colada cruzada ${ }^{2}$ (MLCC), é constituído usualmente por números ímpares a partir de três camadas de lamelas de madeira coladas com adesivos poliuretanos livres de formaldeído dispostas em direções ortogonais. Ele é um produto pré-fabricado produzido em grandes painéis e, depois de usinados na fábrica, formam peças menores para os elementos construtivos como paredes, pisos e coberturas.

A madeira lamelada colada cruzada nasceu em Zurique, Suíça, em 1990, mas foi desenvolvido posteriormente na Áustria através da cooperação entre a indústria e a universidade.

Os principais produtores estão localizados na Áustria: Stora Enso ${ }^{3}$, Binderholz (BBS $)^{4}$, Kreuzlangeholz $(\mathrm{KLH})^{5}$ e May Melnhof Holz $(\mathrm{MMH})^{6}$ (PASSARELLI, 2013).

Os painéis de CLT são fabricados com aproximadamente 3 metros de largura e 16 metros de comprimento, mas as medidas variam conforme o fabricante. As espécies empregadas geralmente são madeiras provenientes de coníferas, conhecidas como softwood, pois apresentam maior facilidade para a laminação devido a sua baixa densidade o que também facilita a penetração dos adesivos, no entanto ainda podem ser utilizadas espécies de folhosas (hardwoods).

O CLT está no mercado internacional há mais de 20 anos e tem sido constante objeto de estudo em muitas pesquisas acadêmicas internacionais para a análise de seu desempenho em relação à sua durabilidade, estabilidade, resistência

\footnotetext{
2 Madeira lamelada ou laminada colada cruzada (MLCC):Termo em português para o Cross laminated timber, porém a terminologia recente no Brasil manteve-se a nomenclatura CLT, por isso será adotada o termo em inglês durante esta dissertação.

${ }^{3}$ http://www.clt.info. Acesso abril/ 2018

${ }^{4}$ http://www.binderholz.com. Acesso abril/ 2018

${ }^{5}$ http://www.klhuk.com. Acesso abril/ 2018

${ }^{6}$ http://www.mm-holz.com. Acesso abril/ 2018
} 
sísmica e ao fogo, acústica e térmica (PAGE, 2016); (POPOVSK, M. et al.,2016); (PAGNONCELLI; FRATTARI, et al., 2014).

\subsection{CLT no cenário internacional}

Ultimamente, na Europa, tem-se observado o aumento da procura por novas soluções estruturais em madeira para construções de porte médio a alto (a partir de cinco pavimentos). O CLT é a opção atualmente mais empregada, pois este sistema construtivo em painéis portantes mostra maior adequabilidade às estruturas elevadas. Entretanto este sistema não é exclusivo das estruturas elevadas, também pode ser utilizado em muitas edificações com uso habitacional, comercial e institucional como mostram as Figuras 4 a 6 .

$\mathrm{Na}$ última década, o sistema construtivo em CLT também vem sendo introduzido na América do Norte, principalmente em construções a partir de cinco pavimentos, pois seu alto nível de pré-fabricação contribui com a facilidade e menor tempo de execução. Como exemplos mais recentes, podem ser citados o Wood Innovation and Design Centre - WIDC (Figura 7) construído no Canadá e o Stadium Drive Residence Halls construído nos Estados Unidos (Figura 8).

Figura 4 - Stadhaus -Murray Grove (2009) - edifício residencial construído em CLT- Hackney, London, UK
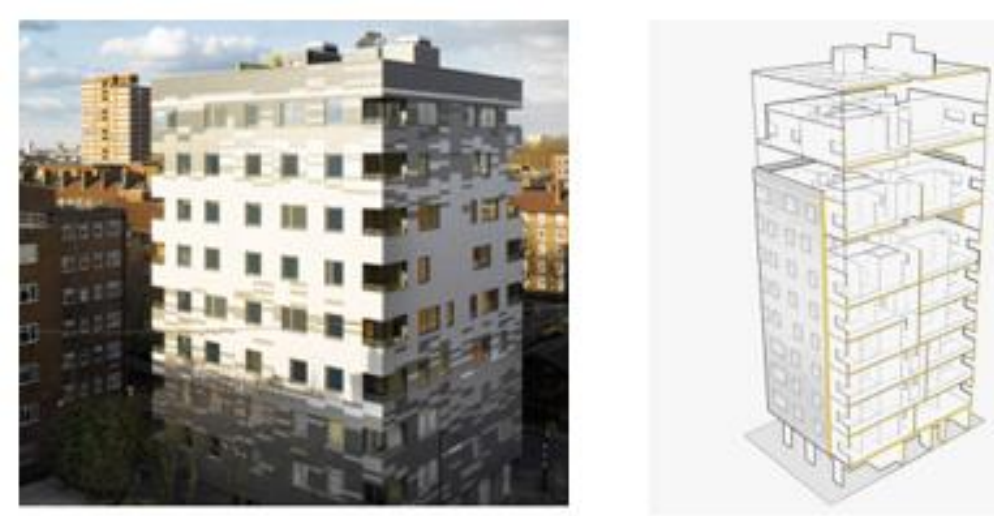

Fonte: http://waughthistleton.com/murray-grove/ 
Figura 5 - The International House by Tzannes Architects - Centro commercial - Sydney, AU

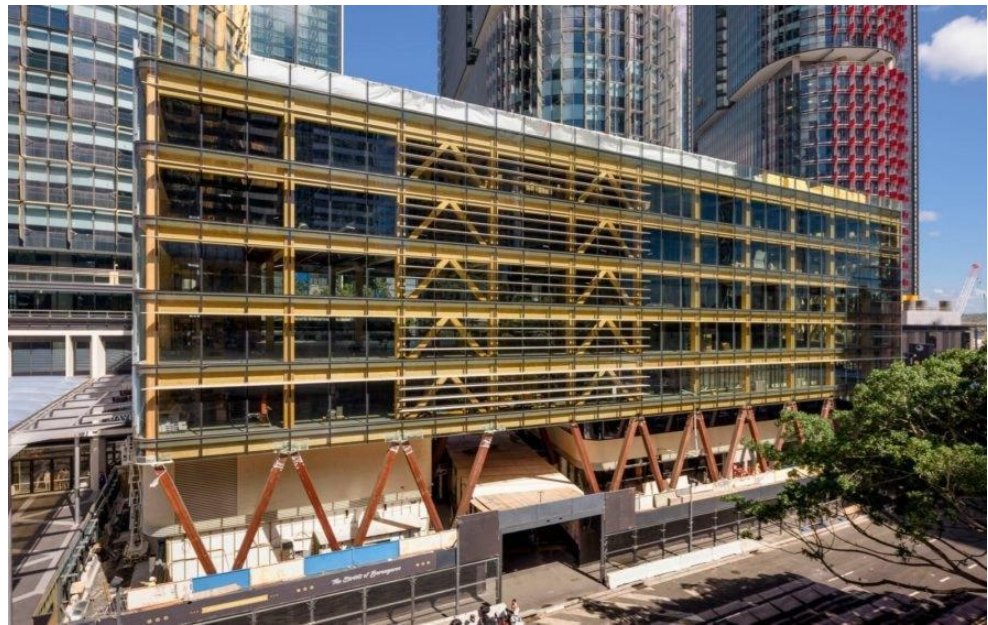

Fonte: https://inhabitat.com/australias-largest-commercial-timber-building-rises-in-sydney/

Figura 6 - Open Academy Norwich (2010)

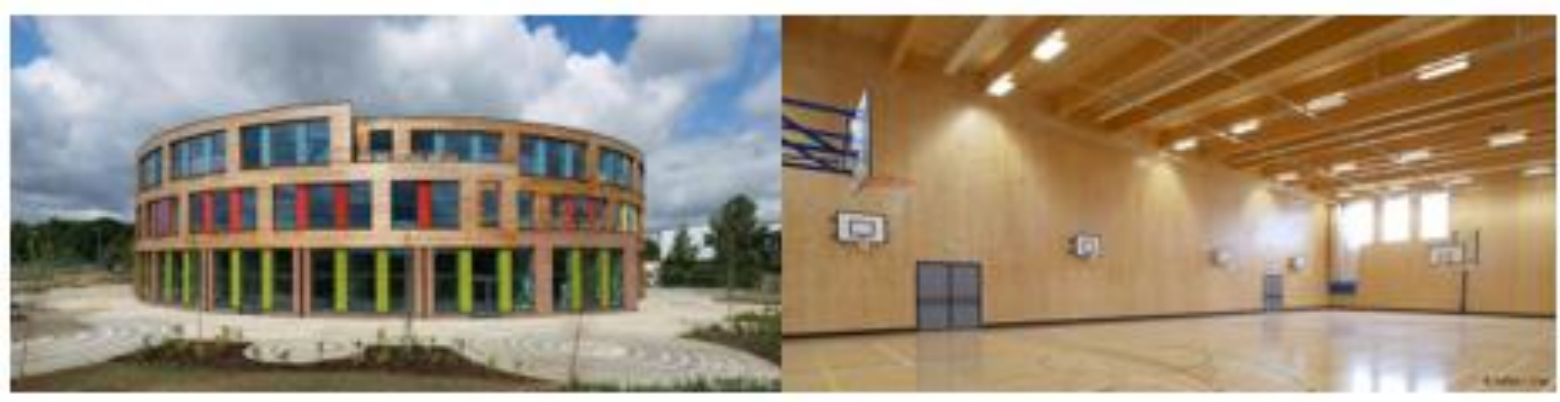

Fonte: https://www.sheppardrobson.com/architecture/view/the-open-academy

Figura 7 - Edifício WIDC (2014) de 29,5m de altura com oito pavimentos construído em CLT, Prince George, BC - Canadá

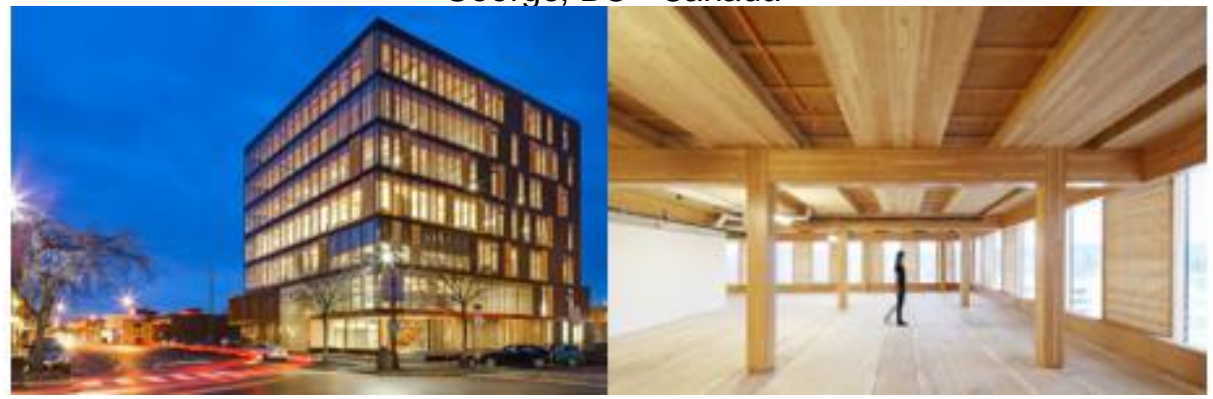

Fonte: http://mg-architecture.ca/work/wood-innovation-design-centre/ 
Figura 8 - Maior edificação a ser construída em CLT Stadium Drive Residence Halls em Portland, Oregon-U.S. A. Área construída aproximada de 19.000 m2, término da obra 2019

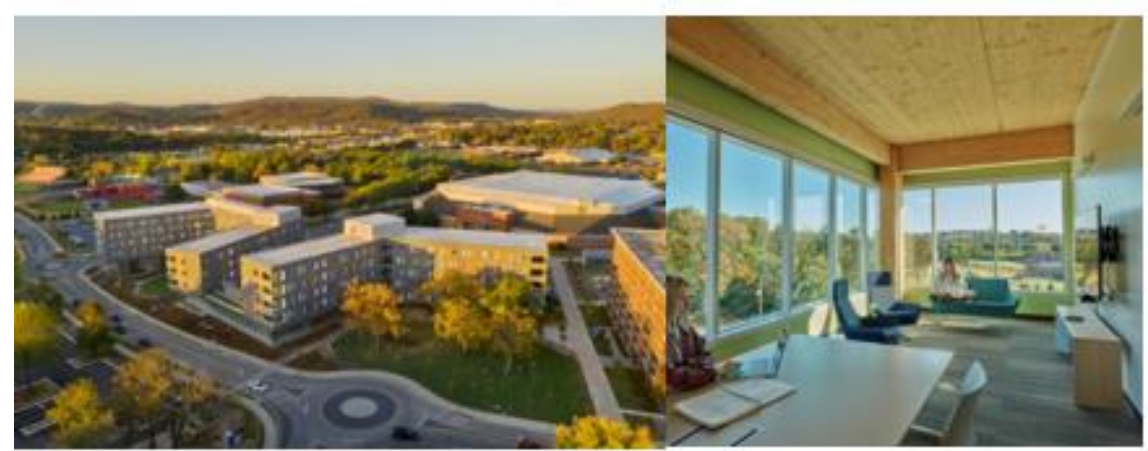

Fonte: https://www.Iwa-architects.com/project/university-arkansas-stadium-drive-residence-halls/

Figura 9 - Edifício residencial Forté Living, 32,2m de altura - Melbourne, Austrália

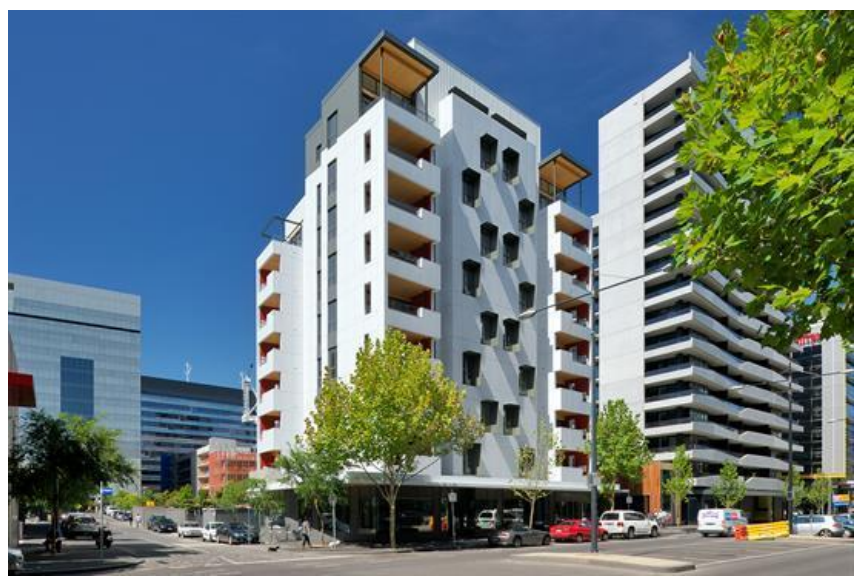

Fonte: Forté (2013)

Parte das construções na Austrália e Nova Zelândia são nos sistemas wood framing ou steel framing. Mas na última década uma variedade de produtos de madeira engenheirada e outros sistemas construtivos, como o CLT, vêm ganhando mercado nestes países (XLAM, 2018).

O Forté Living foi primeiro edifício residencial construído em CLT na Austrália - um edifício de 10 andares que abriga 23 apartamentos, cuja construção foi concluída em 2013 (Figura 9).

\subsection{CLT no cenário nacional}

Há pouco mais de quatro anos no Brasil, o sistema em CLT é empregado em diversos tipos de edificações, para construções novas e em obras de retrofit. Atualmente, o sistema tem sido usado, principalmente, em edifícios residenciais unifamiliares (Figura 10) e residenciais unifamiliares de alto padrão até dois 
pavimentos, devido a seu alto custo inicial, porém a avaliação dos custos deve abranger outras questões, como redução do prazo de obra, por exemplo.

No Brasil, o CLT está começando a ser explorado por meio das iniciativas de pesquisas acadêmicas, comerciais e institucionais para a análise de seu comportamento e desempenho.

Como sistema inovador, o CLT encontra no país alguns desafios para sua aplicação em larga escala. Silva et al. (2016) listam os principais desafios para a utilização da tecnologia no Brasil, conforme seguem abaixo:

- Aceitação da tecnologia por projetistas, construtores e consumidores;

- Grandes investimentos em infraestrutura de produção;

- Necessidade da proximidade da fábrica de CLT das áreas de reservas florestais, devido aos custos com transporte de matéria-prima (madeira serrada);

- Necessidade de projetos de produção e montagem, a exemplo de segmentos industriais, para permitir execução dos diversos elementos em fábrica;

- Criação de padrões e normas específicas;

- Aceitação da inovação tecnológica do CLT por parte das instituições financiadoras, sendo necessária a avaliação pelo SINAT do PBQP-H.

Figura 10 - Casa Tiradentes - Tiradentes-MG projetada pelo arquiteto Alexandre Veneziano, residência de um dormitório $\left(62 \mathrm{~m}^{2}\right)$. Estrutura em CLT executada em 2012 em três dias.

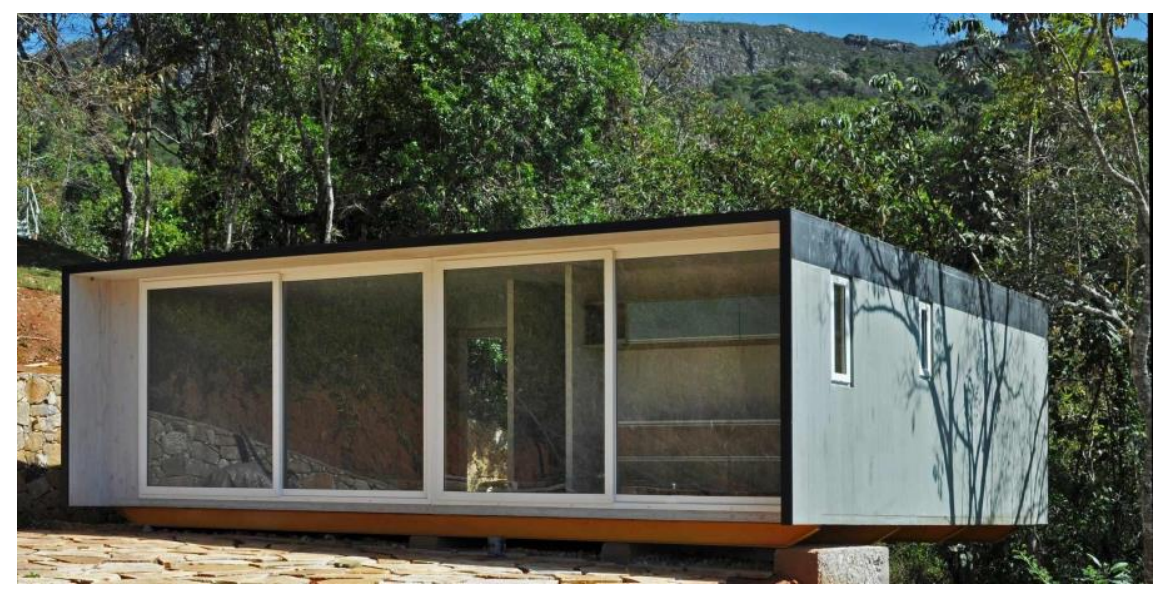

Fonte: Crosslam (2016) 
Tanto os sistemas construtivos em madeiras convencionais como os inovadores precisam ser homologados e avaliados por padrões técnicos de desempenho para que sua utilização se torne racional, além disso, precisam ter respaldo de normas que regulamentam a segurança durante o uso.

No Brasil, o Programa Brasileiro de Qualidade e Produtividade do Habitat (PBQP-Habitat) por meio do Sistema Nacional de Avaliação Técnica (SiNAT), faz a harmonização de procedimentos para a avaliação de novos produtos para a construção, quando não existem normas técnicas específicas aplicáveis ao produto (BRASIL, 2017b). O detentor da tecnologia inovadora deve procurar uma instituição de avaliação técnica (ITA) e fornecer as especificações técnicas da inovação. A ITA inicia o processo, por verificar se já há uma Diretriz SiNAT para o produto ou sistema caso não exista será proposto seu desenvolvimento, este documento consiste na descrição do que deve ser avaliado (caracterização e requisitos de desempenho) e como (métodos de ensaios, cálculos, simulações etc.). A harmonização de procedimentos é necessária para assegurar que todos os aspectos relevantes ao comportamento em uso de um produto de construção sejam considerados no processo de avaliação. A diretriz SiNAT n 005 é a referência até então que pode ser utilizada para sistemas construtivos de madeira.

\subsection{Descrição do produto}

O CLT é um produto de madeira serrada. Seus painéis são formados por camadas de lamelas de madeira maciça, coladas ortogonalmente entre si, com adesivo estrutural e à prova d'água e submetidas a grande pressão. A laminação cruzada distribui a força ao longo das fibras da madeira conferindo propriedades estruturais em ambas as direções, o que contribui para não haver retração ou deformação dos painéis. Os painéis são fabricados como elementos de parede, piso e forro. Os painéis de vedação verticais externos por exemplo suportam até 60,00 $\mathrm{KN} / \mathrm{m}$ no sentido longitudinal como mostra a Figura 11 (flambagem), (CROSSLAM, 2016). 
Figura 11 - Diagrama de disposição das camadas no painel CLT (laje)

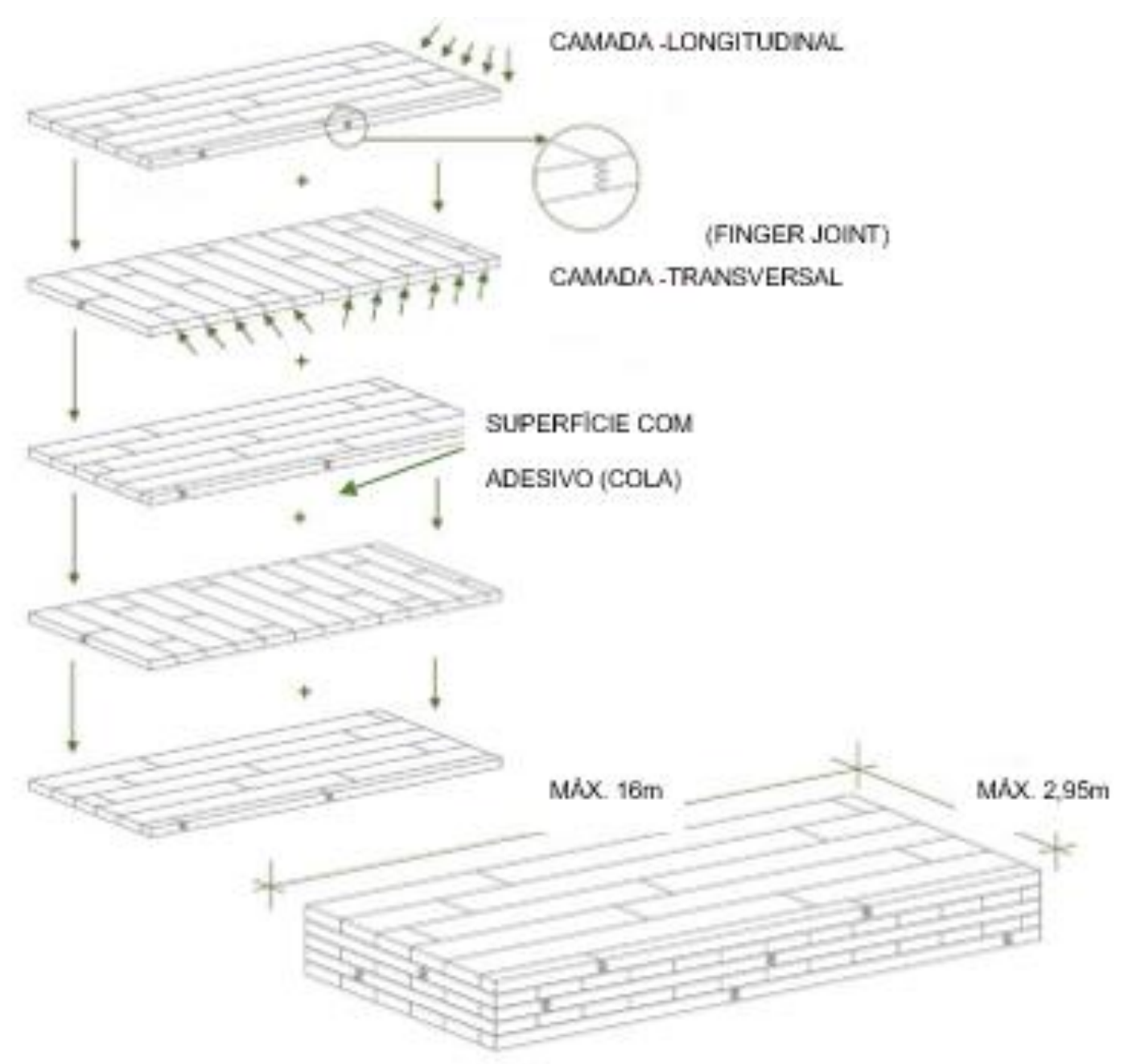

Fonte: ENSO (2015) adaptado pela autora

Na Europa, a norma BS EN 16351:2015 - Timber structures. Cross laminated timber. Requirements (BRITISH STANDARD INSTITUTION, 2015) estabelece disposições relativas às características de desempenho para os painéis de CLT, como reação e resistência ao fogo.

A largura das lamelas deve ser maior ou igual a $40 \mathrm{~mm}$ e menor ou igual a $300 \mathrm{~mm}$ (Figura 12 a). A emenda das lamelas, denominado finger joints, na direção do comprimento é formada pela usinagem de várias pontas simétricas, prismáticas e depois colada entre si (Figura 12 b). 
Para a fabricação dos painéis a norma BS EN 16351:2015 determina que espessura total do painel seja de $500 \mathrm{~mm}$ e as espessuras das camadas podem variar entre $6 \mathrm{~mm}$ e $45 \mathrm{~mm}$, porém para painéis de três camadas, a camada interna pode ter uma espessura de até $60 \mathrm{~mm}$ (Figura $12 \mathrm{c}$ ). A norma também recomenda que os painéis não sejam fabricados com madeira reutilizada.

A norma europeia refere-se ao termo finger joint para as emendas entre peças das lamelas e large finger joint (Figura $12 \mathrm{~d}$ ) para emenda entre a camadas de lamelas sobrepostas e com comprimento mínimo do finger joint de $45 \mathrm{~mm}$. Para evitar ou diminuir fissuras, as lamelas podem ter frisos com profundidade máxima de $90 \%$ de sua espessura e largura máxima de $4 \mathrm{~mm}$ (BRITISH STANDARD INSTITUTION, 2015).

Nos Estados Unidos e Canadá, o sistema construtivo de CLT que está sendo amplamente introduzido, principalmente em anos recentes, também foi elaborada uma norma - a ANSI/ APA PRG 320:2018 - Standard for Performance-Rated CrossLaminated Timber (AMERICAN NATIONAL STANDARDS INSTITUTE, 2018), com objetivo de regulamentar a produção dos painéis nestes países. Esta norma norteamericana estabelece requisitos e métodos para o desempenho e qualidade na fabricação do CLT.

O cross laminated timber pela norma ANSI/ APA PRG 320:2018 é definido como um produto de madeira engenheirada formado com pelo menos três camadas de madeira maciça ou structural composite lumber (SCL) e coladas com adesivo estrutural e resistente a altas temperaturas.

A espessura máxima do painel é de $508 \mathrm{~mm}$ e a espessura das lamelas varia entre $16 \mathrm{~mm}$ e $51 \mathrm{~mm}$. O espaçamento adjacente entre lamelas não deve ser acima de $0,2 \mathrm{~mm}$ e entre camadas $0,3 \mathrm{~mm}$. 
Figura 12 - Composição do painel a) lamela; b) finger joint; c) painel de 03 camadas; d) large finger joint.

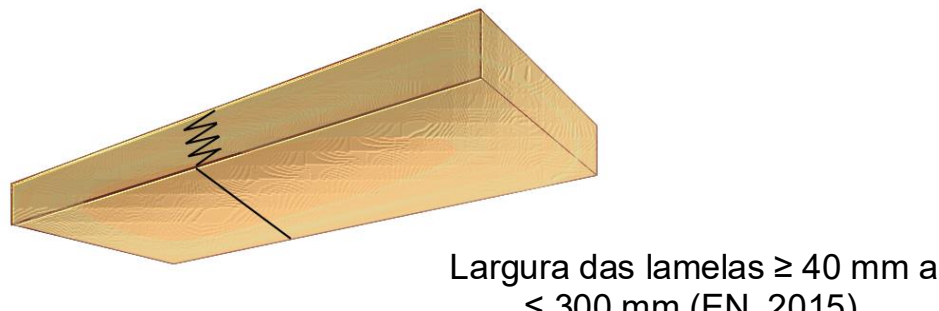

a) $\leq 300 \mathrm{~mm}(\mathrm{EN}, 2015)$.

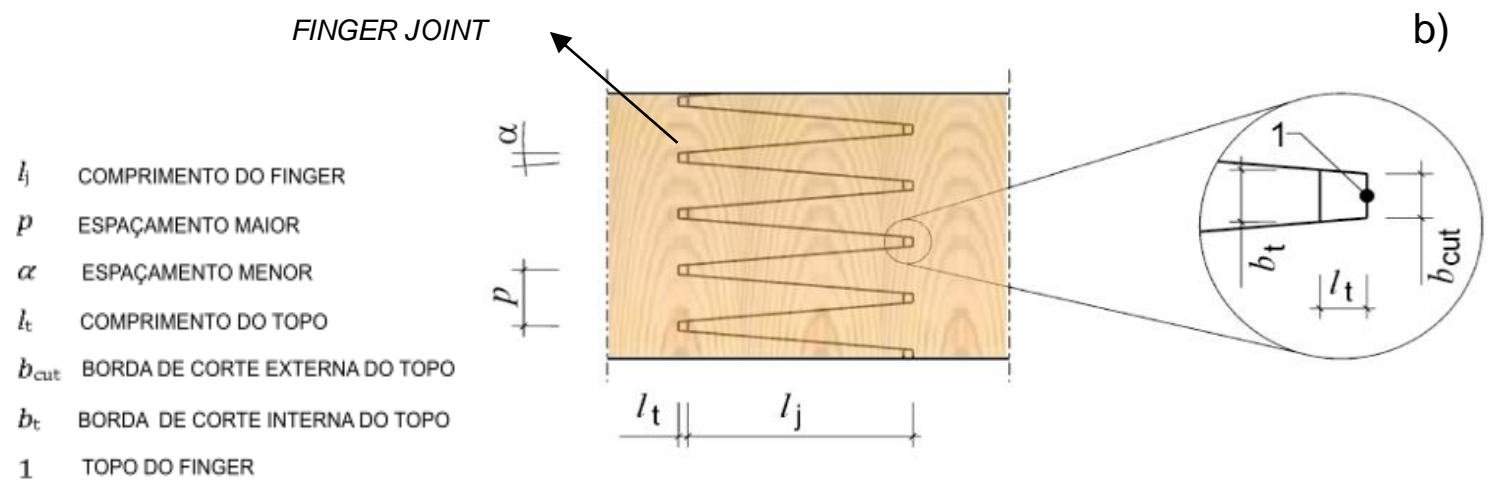

1 CAMADA DE MADEIRA MACIÇA 2 LINHA DE COLA

3 LAMELA

4 ESPAÇAMENTO ENTRE LAMELAS

t ESPESSURA DAS LAMELAS

b LARGURA DAS LAMELAS

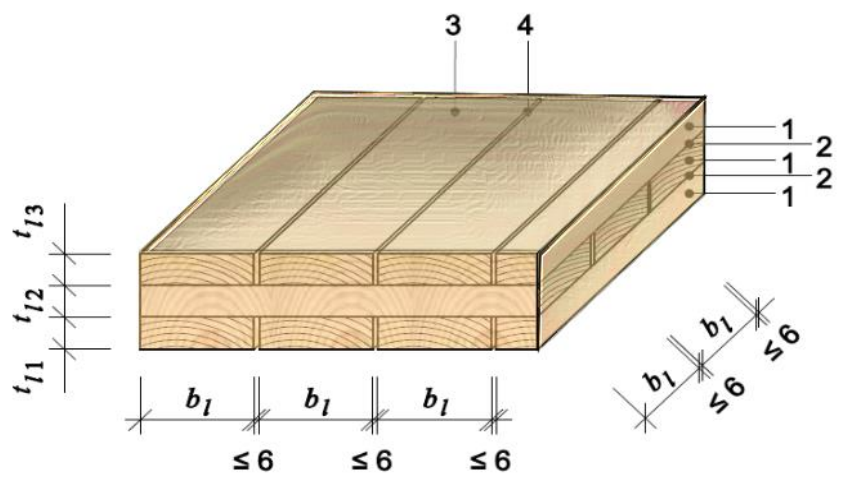

c)

$6 \leq \mathrm{t}_{1,3} \leq 45 \quad 6 \leq \mathrm{t}_{1,2} \leq 60 \quad 40 \leq \mathrm{b}_{1} \leq 300$

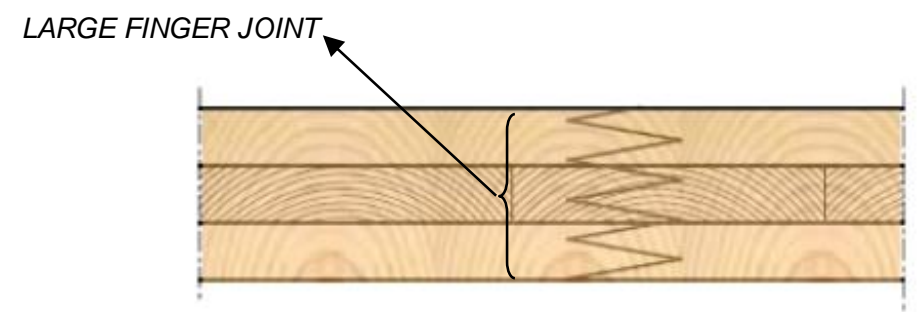

d)

Fonte: British Standard Institution (2015) adaptado pela autora

OBS: Emenda de uma camada não pode coincidir com a das demais camadas. Isso causa perda de resistência do material 
O processo de fabricação inicia-se com a escolha da madeira, que é cuidadosa, respeitando os valores técnicos exigidos pelas normas de controle da qualidade. Todas as lamelas são sujeitas à triagem visual e mecânica, bem como de medição de sua umidade (OLIVEIRA, 2018). Os painéis de CLT são produzidos com madeira seca, de acordo com as normas europeias aplicáveis, apresentando uma de teor de umidade perto dos $12 \%$, com variações de mais ou menos $2 \%$, de forma a evitar o ataque de organismos xilófagos.

O projeto estrutural dos painéis em CLT deve ser realizado com base em projetos, normas e regulamentos ${ }^{7}$. O devido cuidado também é aconselhado ao comparar espessuras de elementos de CLT de vários fabricantes, pois há diferentes processos de produção e dependendo da espécie empregada, os produtos de madeira laminada cruzada podem ter diferentes propriedades, no que diz respeito à rigidez, à resistência aos esforços de flexão e de cisalhamento.

Para a análise estrutural de madeira laminada cruzada, diferentes modelos de cálculos foram desenvolvidos. Para o dimensionamento e o projeto estrutural do sistema, em países europeus utiliza-se o EN 1995-1-1: Eurocode 5: Design of timber structures - Part. 1-1: General - Common rules and rules for buildings (EUROPEAN COMMITTEE FOR STANDARDISATION, 2004), também deve-se levar em conta que o padrões nacionais em vários países diferem uns dos outros em alguns aspectos (KLH, 2018).

No Brasil, a primeira fábrica de CLT está localizada na cidade de Suzano, São Paulo. Os painéis produzidos por esta fábrica podem ser de três, cinco ou sete camadas (lamelas), variando de $57 \mathrm{~mm}$ a $250 \mathrm{~mm}$ de espessura e têm dimensões mínimas de $440 \mathrm{~mm}$ de largura $\times 8.050 \mathrm{~mm}$ de comprimento e dimensões máximas de $3.000 \mathrm{~mm}$ de largura $X 12.000 \mathrm{~mm}$ de comprimento (CROSSLAM, 2016).

A matéria-prima utilizada é a madeira de Pinus taeda seca em estufa, com $12 \%+/-2 \%$ de umidade, podendo ser tratada em autoclave com borato de cobre cromatado - CCB, processo mais indicado, pois há penetração total do preservativo,

\footnotetext{
${ }^{7}$ No Brasil ainda não há nenhuma norma específica para o sistema construtivo em CLT.
} 
ou com imersão em solução de boro (neste caso o produto acabado), conforme informado pelo fabricante.

Além do Pinus taeda, existem alguns estudos em painéis de CLT fabricados com a espécie de Pinus elliottii que demonstram boa resistência à compressão paralela às fibras também para esta espécie (MUNIS et al., 2016).

O adesivo utilizado é à base de poliuretano resistente ao fogo, monocomponente, livre de formaldeídos, com teor de sólidos de 100\%, certificado para uso estrutural e à prova d'água. Para lajes e paredes são utilizados dois tipos de painéis com lamelas externas no sentido longitudinal (geralmente no uso de lajes) e com as lamelas externas no sentido transversal (geralmente no uso de paredes).

Os painéis são montados colocando as lamelas lado-a-lado, até atingir o comprimento e largura das medidas especificadas pelo fabricante. Cada camada sucessiva é colocada perpendicular à camada precedente como exemplo da Figura 11. Em seguida cada camada é pulverizada com adesivo e todo o elemento com suas respectivas camadas são prensados verticalmente e horizontalmente em uma grande prensa a vácuo. Os painéis prensados são cortados na medida, de acordo com as especificações de projeto, e são finalizados por uma máquina fresadora.

Para cada elemento, como parede, laje e piso, deve ser especificado a quantidade mínima de camadas. Para paredes até sete camadas e para lajes e pisos, o número de camadas será determinado pela carga a ser aplicada, garantindo a estabilidade do sistema, assim como conforto térmico, acústico, segurança contra incêndio e etc.

Elementos de construção em CLT também podem receber recortes de vãos para portas e janelas ou outros tipos de aberturas ainda na fábrica, garantindo maior qualidade à pré-fabricação do sistema. Também outros detalhes podem ser feitos como recortes para vigas, contornos e formas especiais internas e externas, recortes para eletrodutos, tomadas e instalações hidrossanitárias, baseados nos desenhos de fabricação aprovados e fornecidos pelo o cliente e / ou a construtora. 


\subsection{Descrição da montagem do sistema construtivo}

Para a execução do edifício com o sistema CLT, antes dos componentes chegarem ao canteiro de obras para sua montagem, é necessário haver um bom planejamento que envolve identificar o tipo de equipamento de elevação e as medidas necessárias para determinar a posição exata e o espaço para o trabalho do equipamento e da aproximação do caminhão de entrega.

O mecanismo de elevação (Figura 13 e 14) para montagem pode ser diferente do equipamento de elevação usado para descarregar os componentes do sistema. Os elementos de CLT são presos ao gancho do guindaste com seu mecanismo de elevação para serem levados até a posição correta na base é recomendado que estes ganchos já venham fixados nos painéis da fábrica, e o descarregamento na obra seja feito na ordem inversa à da montagem.

A equipe de montagem deve trazer os elementos na ordem e nas posições corretas, para serem fixados e assim acontece sucessivamente. A montagem dos componentes e elementos é realizada conforme o plano de montagem e/ou planejamento detalhado baseado nas informações fornecidas pelo engenheiro estrutural.

Equipamentos de elevação, como exemplo, as plataformas aéreas (dispositivo mecânico usados para fornecer acesso temporário a pessoas ou equipamentos a áreas inacessíveis, em altura) são mais adequados para montagem dos componentes, mesmo para edifícios maiores com posições altas de instalação, como construção de galpões.

Os trabalhos seguintes, como o de instalações elétricas e hidrossanitárias, iniciam imediatamente após os componentes em CLT terem sido montados, já que este é um tipo de construção a seco.

O sistema construtivo de CLT pode ser compatibilizado com outros tipos de sistemas e/ou outros produtos à base de madeira como, por exemplo, MCL (madeira colada laminada), LVL (laminated veener lumber), LSL (laminated strand lumber) e outros materiais como o aço que pode ser utilizado na estrutura (vigas e pilares) como mostra a Figura 15. 
Figura 13 - Acesso para o descarregamento dos painéis
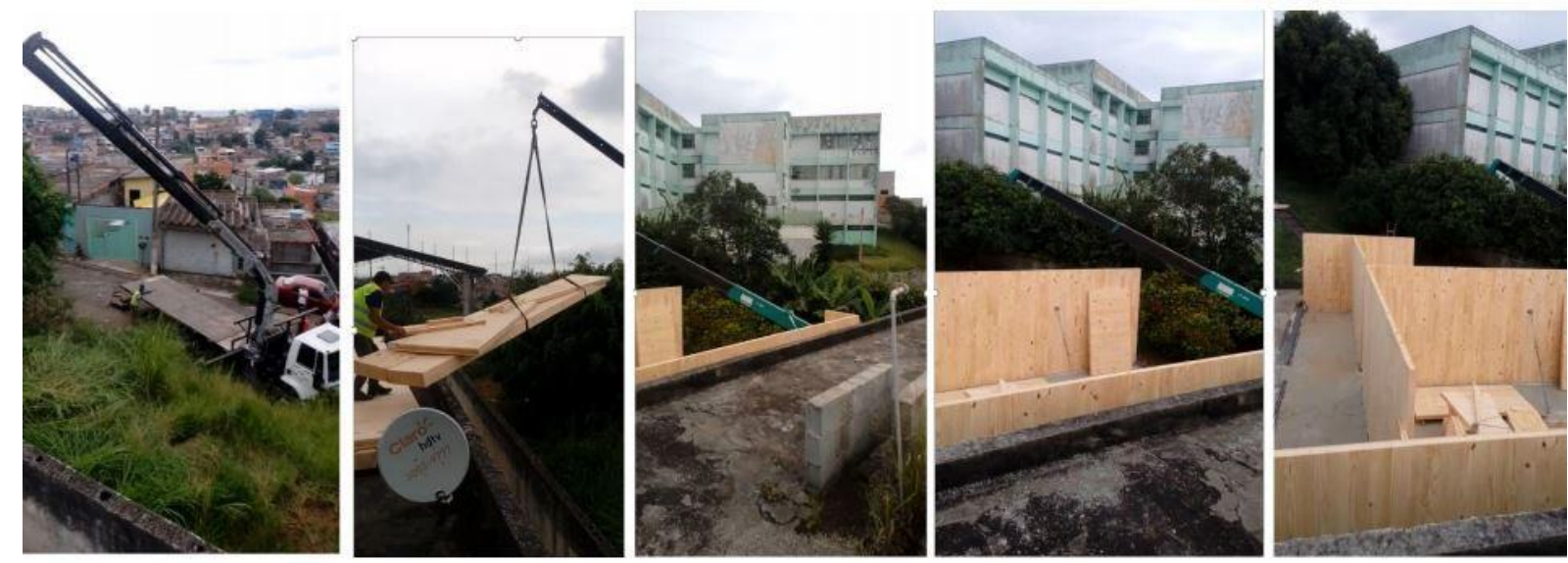

Fonte: Crosslam (2018)

Figura 14 - Elevação e posicionamento dos painéis
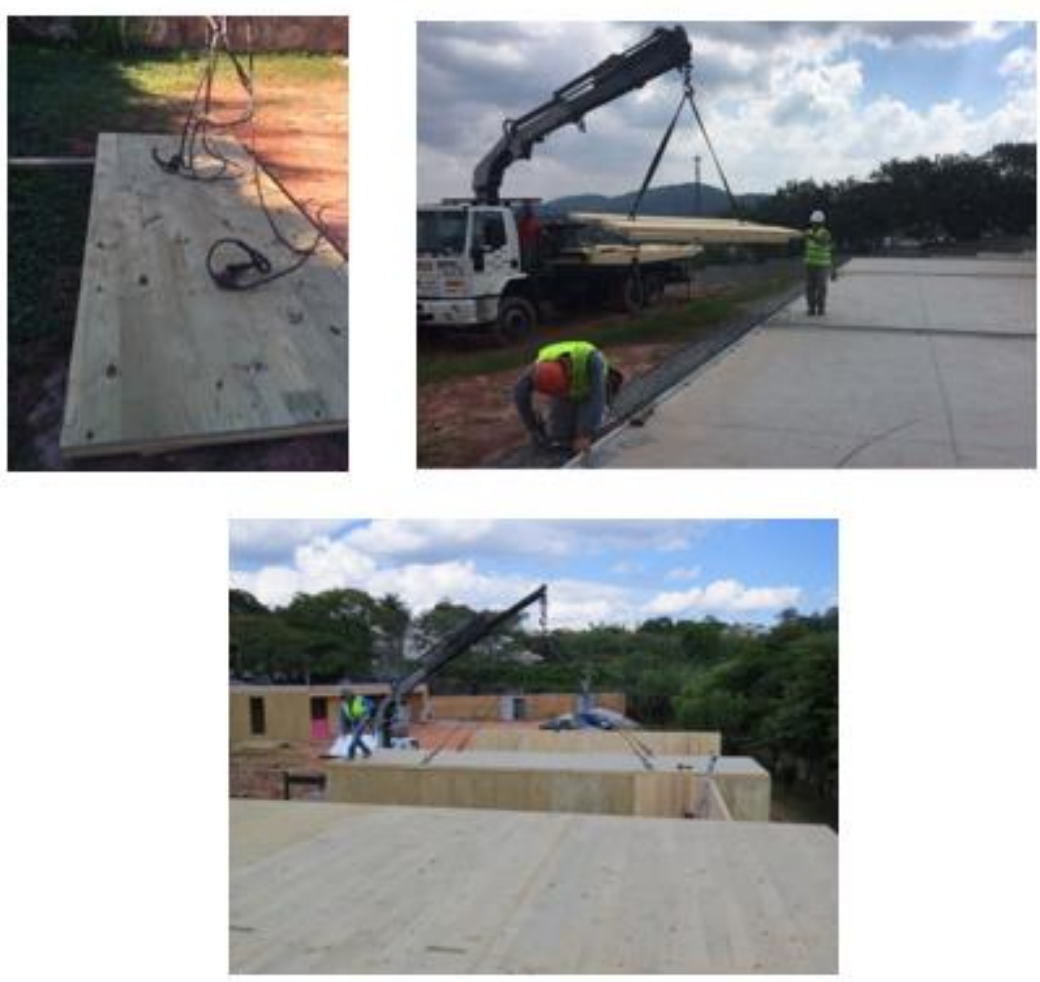

Fonte: Crosslam (2018) 
Figura 15 - Obra de residência unifamiliar construída em painéis de CLT, wood framing e vigas e pilares metálicos.

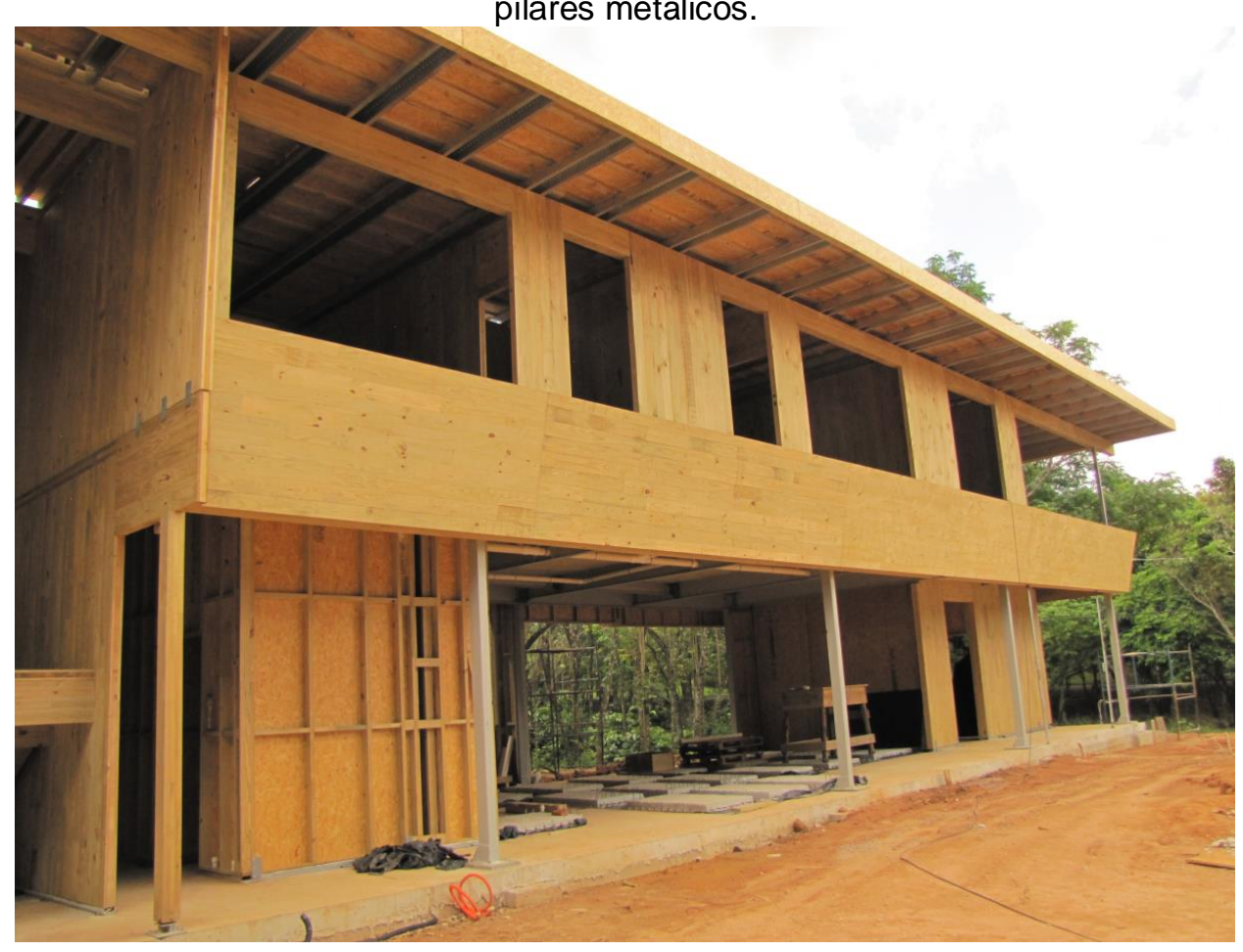

Fonte: Castilho (2019)

Aspectos estruturais e físicos, como isolamento acústico, estanqueidade à água e ao ar e proteção ao fogo podem ser obtidos pelo o uso de isolantes térmicos de diferentes materiais como fibras de madeira e fibras minerais como será apresentado no capítulo 05.

Os painéis CLT são montados sobre uma base de concreto como radiers ou sobre lajes com fundação que evite o contato da madeira com o solo. Antes da fixação do painel deve ser locada a posição das paredes na base (laje).

Figura 16 - Tipos de base para a instalação do painel
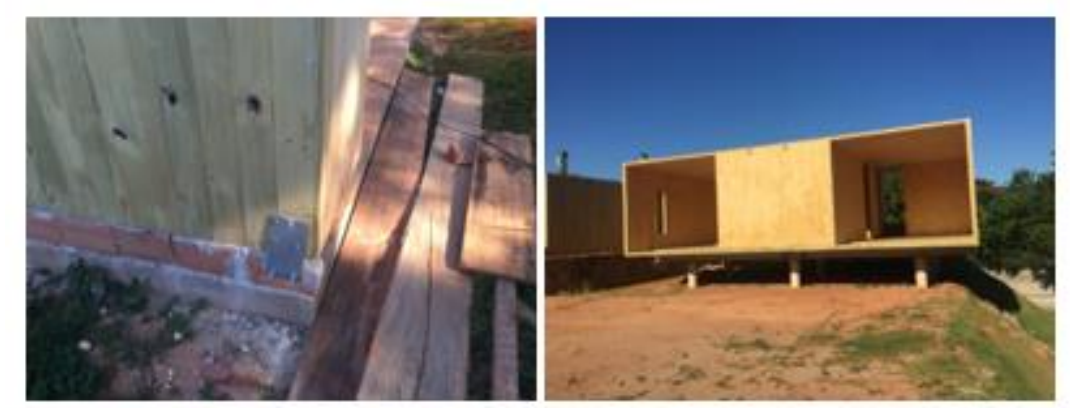

Fonte: da autora (2018) 
O painel pode ser instalado diretamente na base ou sobre uma camada de argamassa seca ou úmida ou sobre sarrafo de madeira para compensação de tolerância (regularização da superfície); também pode ser instalada sobre uma fiada de blocos cerâmicos ou de concreto e pilotis (Figura 16), a impermeabilização da base deve ser feita com mantas e/ou produtos específicos, a fim de garantir que a umidade ascendente da fundação e do solo não entre em contato com o painel.

Para a fixação do painel tanto na base como a outros componentes e elementos do sistema são utilizados parafusos, conectores comuns e conectores de ancoragem (transição para o concreto). Os tipos e números de fixadores resultarão dos planos de construção detalhados, bem como dos cálculos estáticos. Dependendo do layout arquitetônico e da montagem, os fixadores padrões às vezes podem não ser suficientes. Neste caso, componentes de aço especial devem ser dimensionados por um engenheiro estrutural para garantir a estabilidade.

Por exemplo, conectores padrão não são suficientes para ancoragem de tensão, no caso de cargas sísmicas. Também devem ser observadas as distâncias máximas de borda permitidas para os esforços de tração e cisalhamento do painel.

Para posicionar os conectores corretamente é recomendado fazer uma projeção da planta da edificação na base, mostrando a locação das paredes como mostra na Figura 17. Isso deve ser feito com a maior exatidão possível, com verificação dos ângulos. Para definir a posição dos conectores, requer-se que cada parede seja esboçada com a espessura do painel. Normalmente, a distância entre conectores será entre 100 e $150 \mathrm{~cm}$. Durante a montagem, estes conectores serão úteis para o posicionamento dos suportes de montagem para os elementos do sistema. Em cada suporte de fixação, a altura exata será determinada usando um instrumento de nivelamento. Imprecisões serão compensadas com material de suporte adequado (KLH - Assembly and Installation, 2012). 
Figura 17 - Esboço da planta para posicionar os conectores
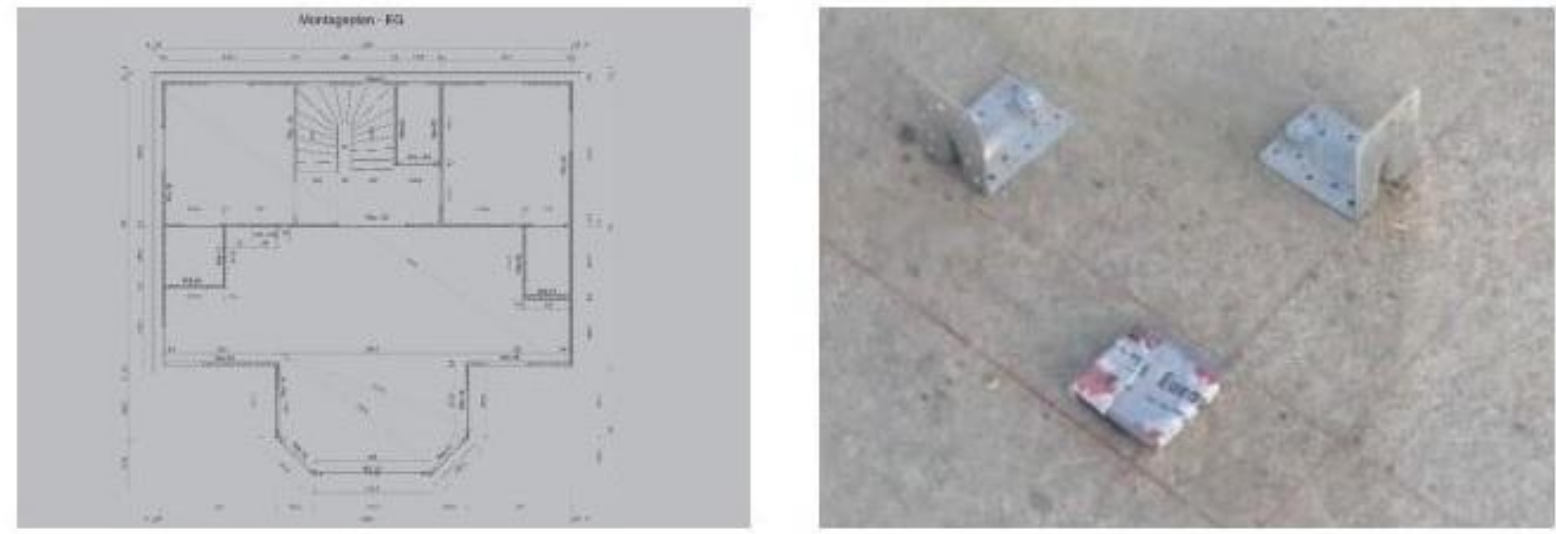

Fonte: $\underline{\text { https://www.klh.at/ }}$

No final, as juntas abertas entre o painel de parede de CLT e o piso devem ser preenchidas. Esta etapa da montagem deve ser concluída antes de iniciar a fixação dos painéis do forro e/ou cobertura.

Os painéis de parede CLT devem ser, de preferência, todos da mesma altura (sem juntas). Se caso a altura das paredes for maior do que a altura máxima do painel as placas da parede podem ser unidas verticalmente ou como última alternativa serem unidas horizontalmente.

Mas, de modo geral, a fixação entre dois painéis em $90^{\circ}$ pode ser feita com os conectores e/ou com parafusos em linha reta ou inclinado, sendo este último o mais indicado, conforme mostra as Figuras 18 e 19.

Figura 18 - Exemplos das posições dos parafusos para a fixação do painel
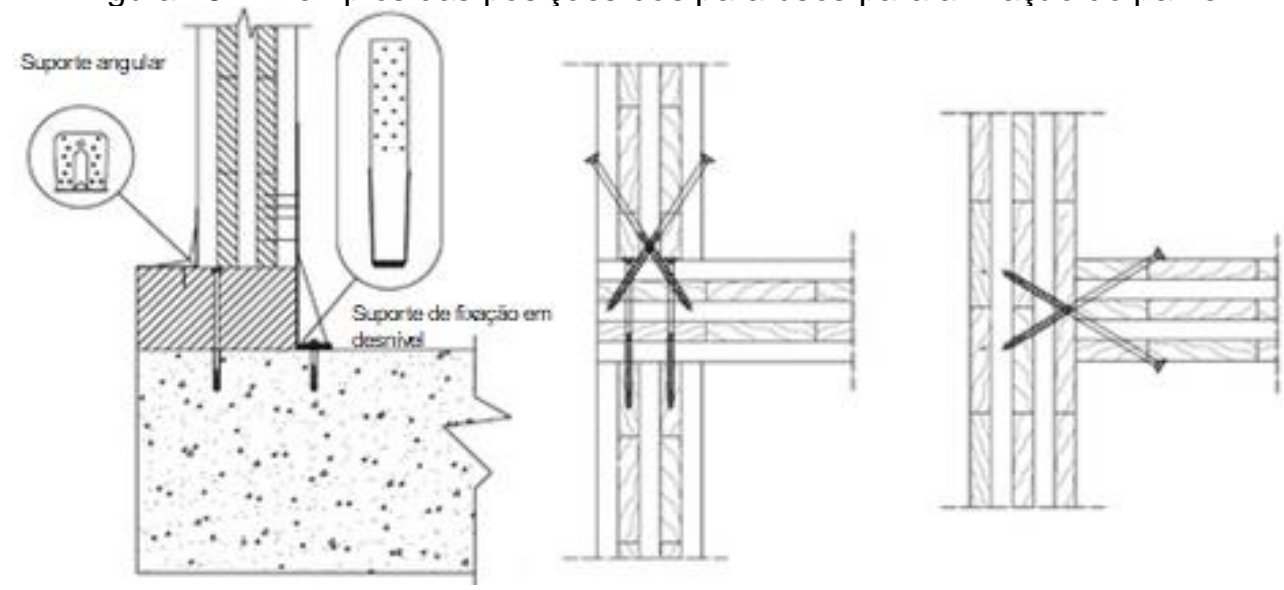

Corte sem escala

Fonte: Tomasi e Smith (2015) 
Figura 19 - Fixação: a) suporte angular (canto) com parafusos tipo SKR (1) ou SKS (2); b) com parafuso de rosca completa VGZ
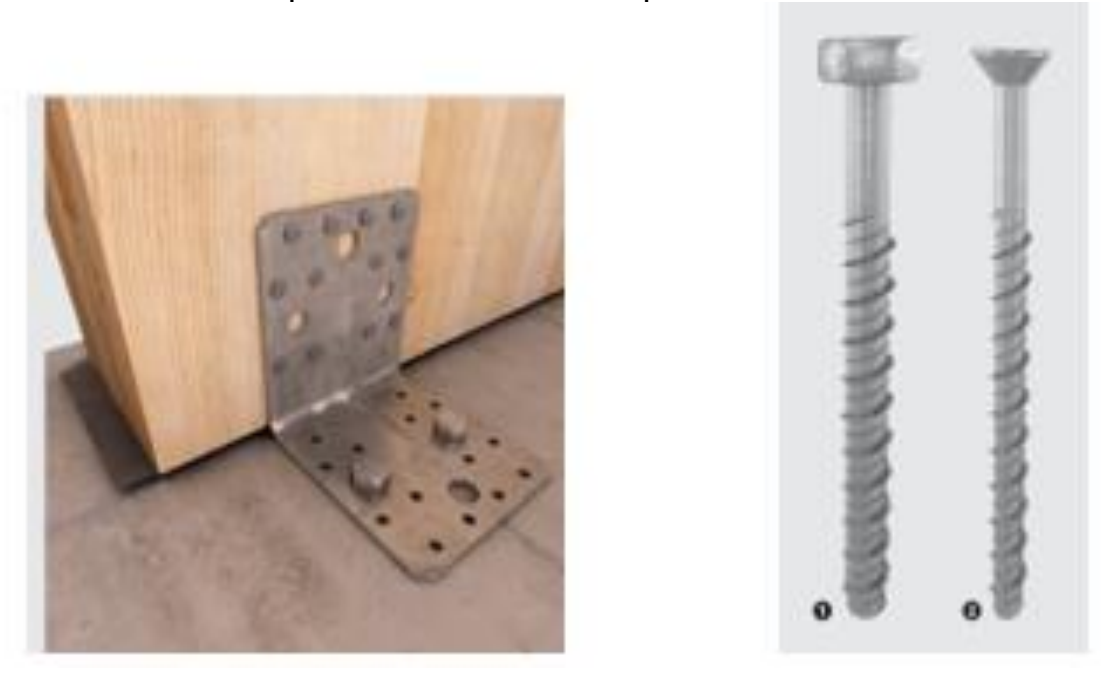

a)

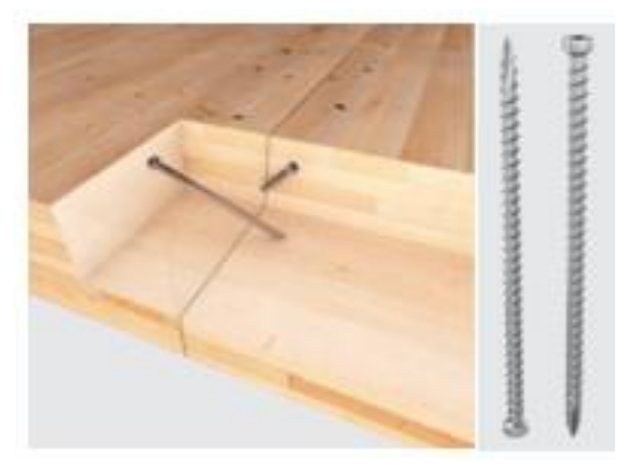

b)

\section{Fonte: https://www.rothoblaas.pt/}

Durante a montagem, os elementos devem receber proteção contra a exposição direta ao clima como no caso da cobertura e das fachadas, com mantas, membranas e produtos e/ou revestimentos específicos para criar uma barreira impermeável. É recomendada a instalação de uma membrana hidrófuga que vai à face externa do painel para controlar a umidade e o vapor que atingem a edificação (Figura 20).

Figura 20 - Sequência da proteção do painel até o acabamento externo

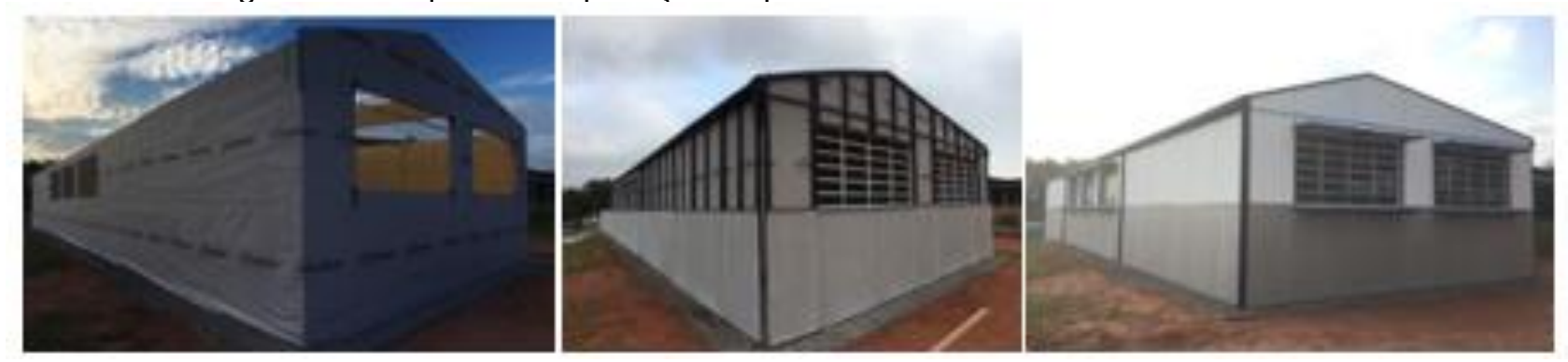

Fonte: Crosslam (2018) 
Para as instalações elétricas e hidrossanitárias, são fresados canais no painel (Figura 21) para a passagem da tubulação nas instalações hidrossanitárias também é recomendado fazer um isolamento acústico. É importante assegurar que estes canais sejam executados na direção da laminação da primeira camada. Caso seja necessário um canal em outra direção é preciso fazer uma análise estrutural da área, pois este resultará em enfraquecimento na estabilidade do painel.

No que diz respeito às extremidades da parede (por exemplo, junto às aberturas), deve ser levada em conta que a capacidade da carga estática pode ser reduzida. Por exemplo, quando é fresado um canal no painel para a passagem de vários eletrodutos e esta diminuição da espessura estiver bem próxima às portas e janelas, a resistência do painel pode ser reduzido em até 30\%. Também, caso sejam instalados muitos canais para a passagem de serviços no painel, será necessária a análise estrutural deste elemento.

Furos e canais para a passagem de instalações elétricas e hidrossanitárias devem ser adequadamente selados, assim como chaminés ou furos para ventilação e similares (KLH - Assembly and Installation, 2012).

Após a instalação das tubulações elétricas e hidrossanitárias no painel de parede e teto, o CLT pode receber fechamento com placas de gesso adequadas para cada ambiente (por exemplo, placas de gesso RU - resistente à umidade nas áreas molhadas e molháveis) e pode, ou não, receber barreiras impermeáveis como revestimentos cerâmicos, tintas à base de epóxi etc. (Figura 22).

No piso, as tubulações são instaladas diretamente sobre o elemento e devem ter no máximo $80 \%$ da espessura do painel, então se faz a proteção mecânica mais adequada, executa-se o contra piso e posteriormente coloca-se o revestimento de acabamento de piso e lajes (teto). 
Figura 21 - Ranhuras para passagem da tubulação elétrica
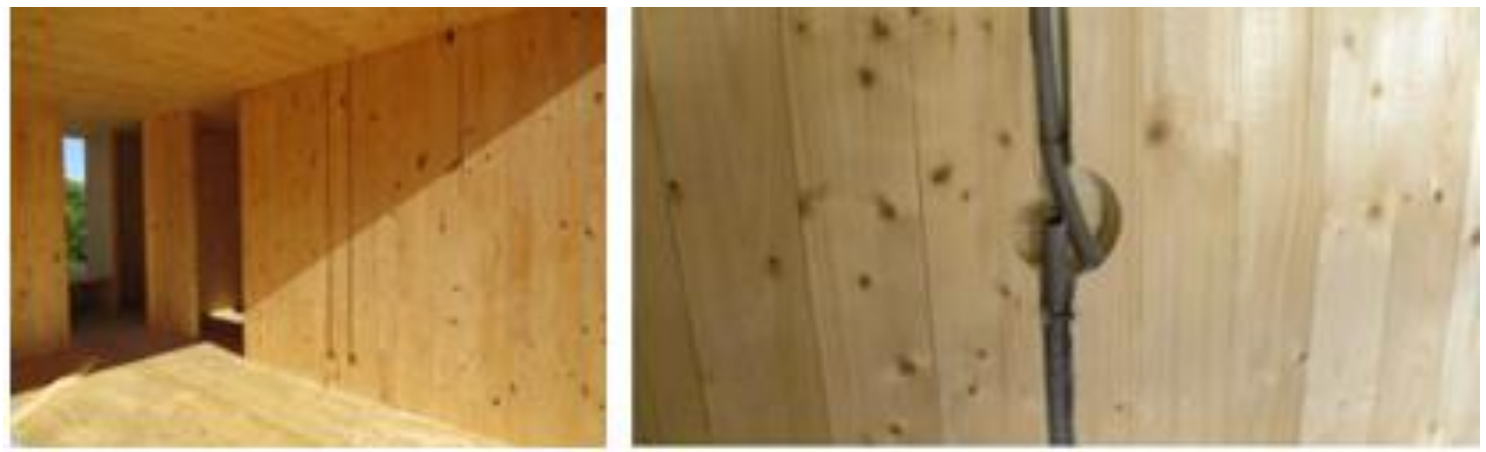

Fonte: Crosslam; KLH, (2018)

Figura 22 - Instalações hidrossanitárias e fechamentos em placas de gesso e revestimento cerâmicos
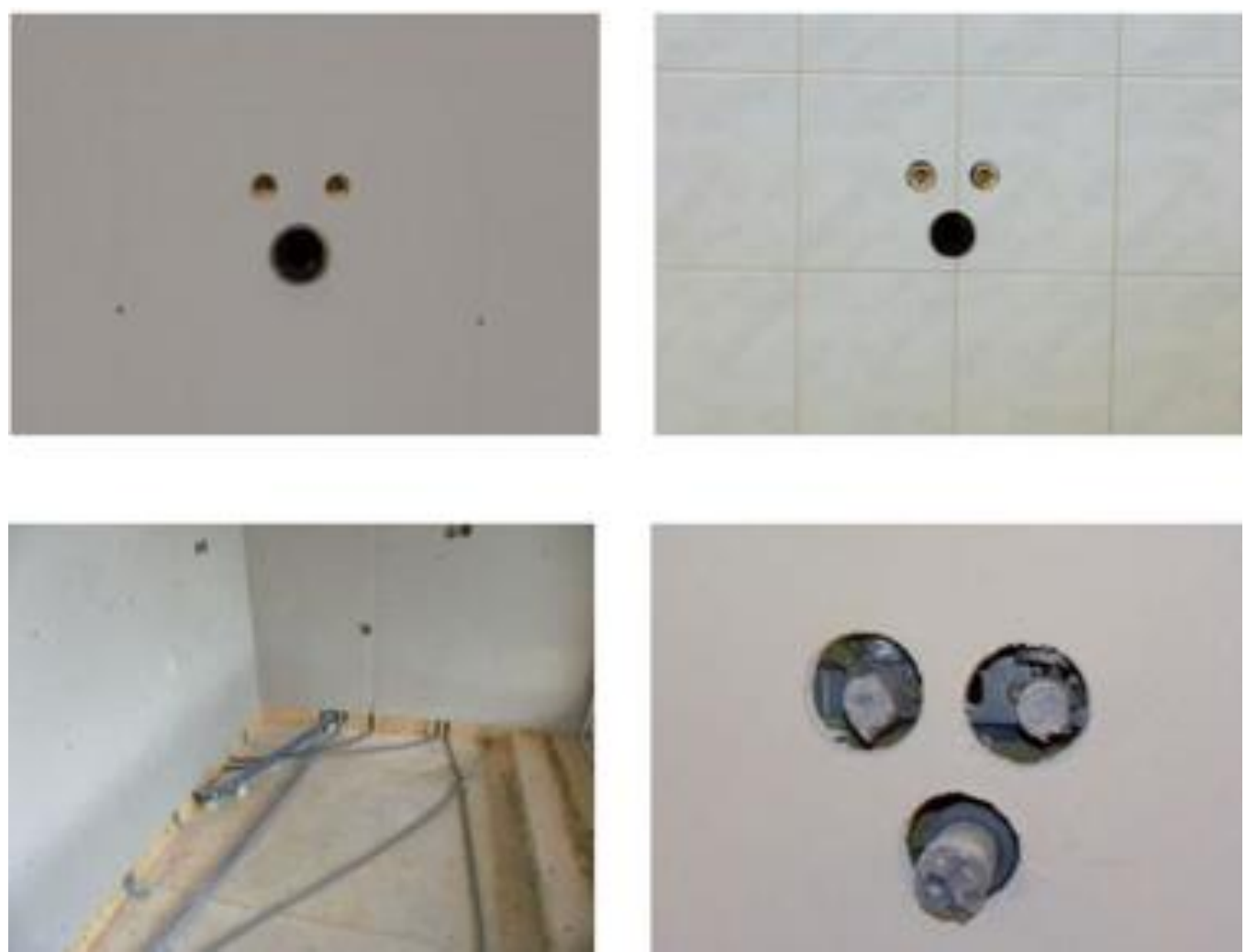

Fonte: https://www.klh.at/ 
Figura 23 - Etapas da montagem dos painéis

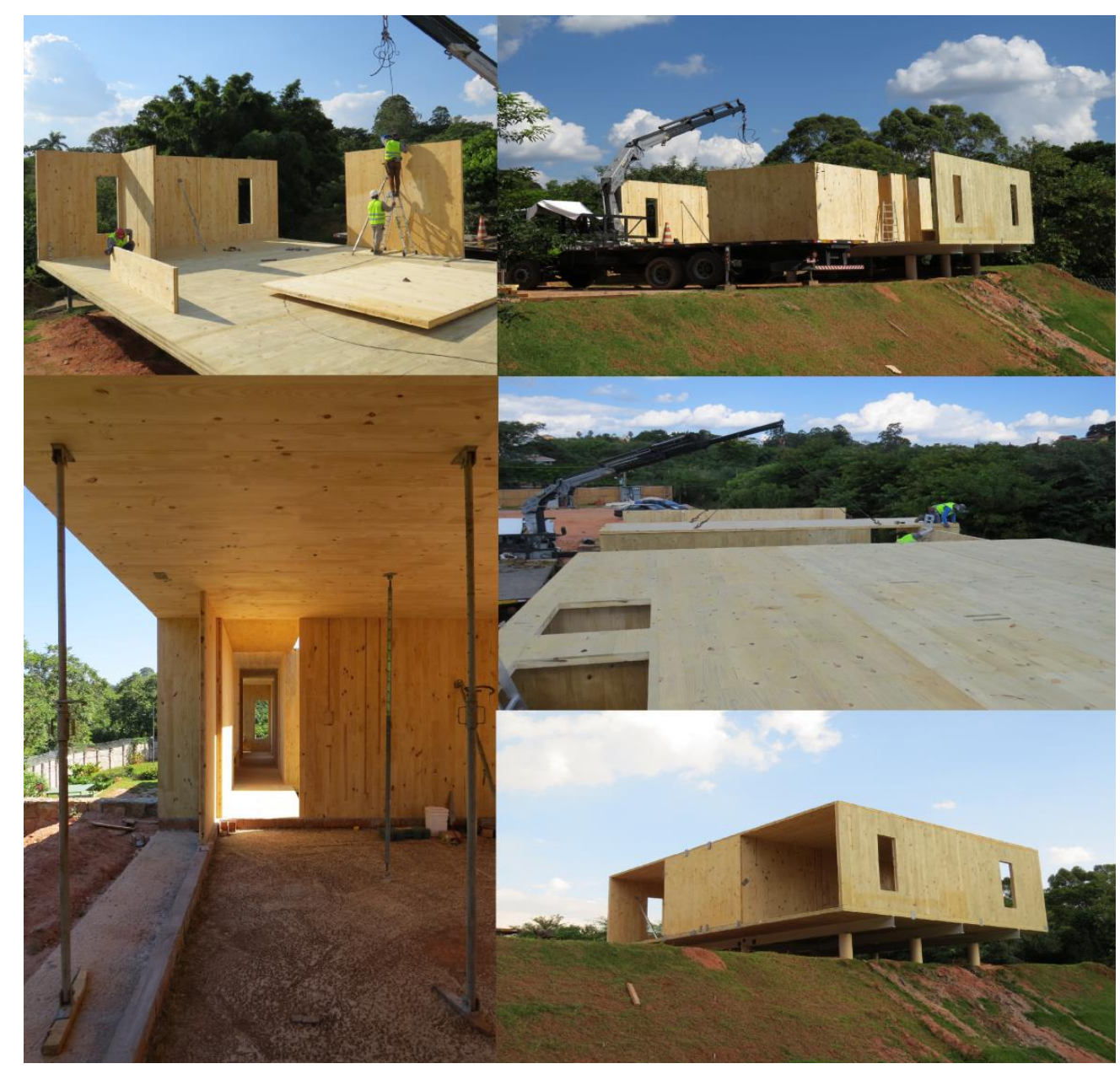

Fonte: Crosslam (2018)

Em países com experiência na montagem deste sistema construtivo, o trabalho de instalação pode ser concluído num tempo de aproximadamente 20 $40 \%$ do tempo necessário para as estruturas tradicionais (Figura 23). Também a aplicação de material de isolamento, fachadas e a instalação de portas e janelas podem ser feitas com uma economia de 10 a $30 \%$ de tempo. No Brasil, ainda não há dados com base em prazos de montagem com todos os demais elementos construtivos que envolvem o processo de execução do sistema para que possam ser quantificados se há uma diminuição do tempo de execução em relação a sistemas de uso convencional. 


\section{PARÂMETROS DA SEGURANÇA CONTRA INCÊNDIO}

A principal finalidade da segurança contra incêndio em edificações é evitar ou minimizar o risco à vida das pessoas e a redução das perdas do patrimônio, ou seja, a destruição parcial ou total da edificação (VARGAS, ONO e SILVA, 2010).

Harmathy (1984, apud BERTO, 1991, p.3) diz que:

"[...] um edifício seguro contra incêndio pode ser definido como aquele onde há alta probabilidade de que todos os ocupantes sobrevivam a um incêndio sem comprometer a integridade física e os danos ocorridos na propriedade sejam limitados ao entorno da edificação".

O projetista deve ter pleno conhecimento dos fenômenos principais, dos conceitos básicos e dos parâmetros para análise da segurança contra incêndios e dos materiais incorporados no sistema construtivo, assim como o conhecimento do comportamento ao fogo diante desses materiais, para evitar que o princípio do incêndio e sua evolução ocorram, criando condições especialmente nocivas às pessoas.

\subsection{A evolução do incêndio}

O fogo é uma combustão, processo físico-químico, em que duas ou mais substâncias reagem com a emissão de calor, luz e produtos residuais. Os componentes que devem coexistir para a ocorrência do fogo são combustível (ex.madeira), comburente (oxigênio), calor (faísca, chama, radiação térmica), que sob condições apropriadas possibilita a reação em cadeia que resulta na combustão (CORPO DE BOMBEIROS DA POLÍCIA MILITAR DO ESTADO DE SÃO PAULO, 2018 a).

Ao serem aquecidos, vapores combustíveis se desprendem da superfície do sólido e se misturam ao oxigênio do ar, podendo formar uma mistura inflamável responsável pela ignição. Uma fagulha ou mesmo o simples contato com uma superfície muito aquecida pode gerar uma chama na superfície do sólido combustível já aquecido. 
O crescimento do fogo dependerá do primeiro item ignizado, das características do comportamento ao fogo dos materiais na proximidade do item ignizado e sua distribuição no ambiente (SEITO, 2008).

A Figura 24 mostra uma curva hipotética de evolução do calor num incêndio com suas diferentes fases, descritas a seguir.

Figura 24 - Evolução do incêndio na edificação

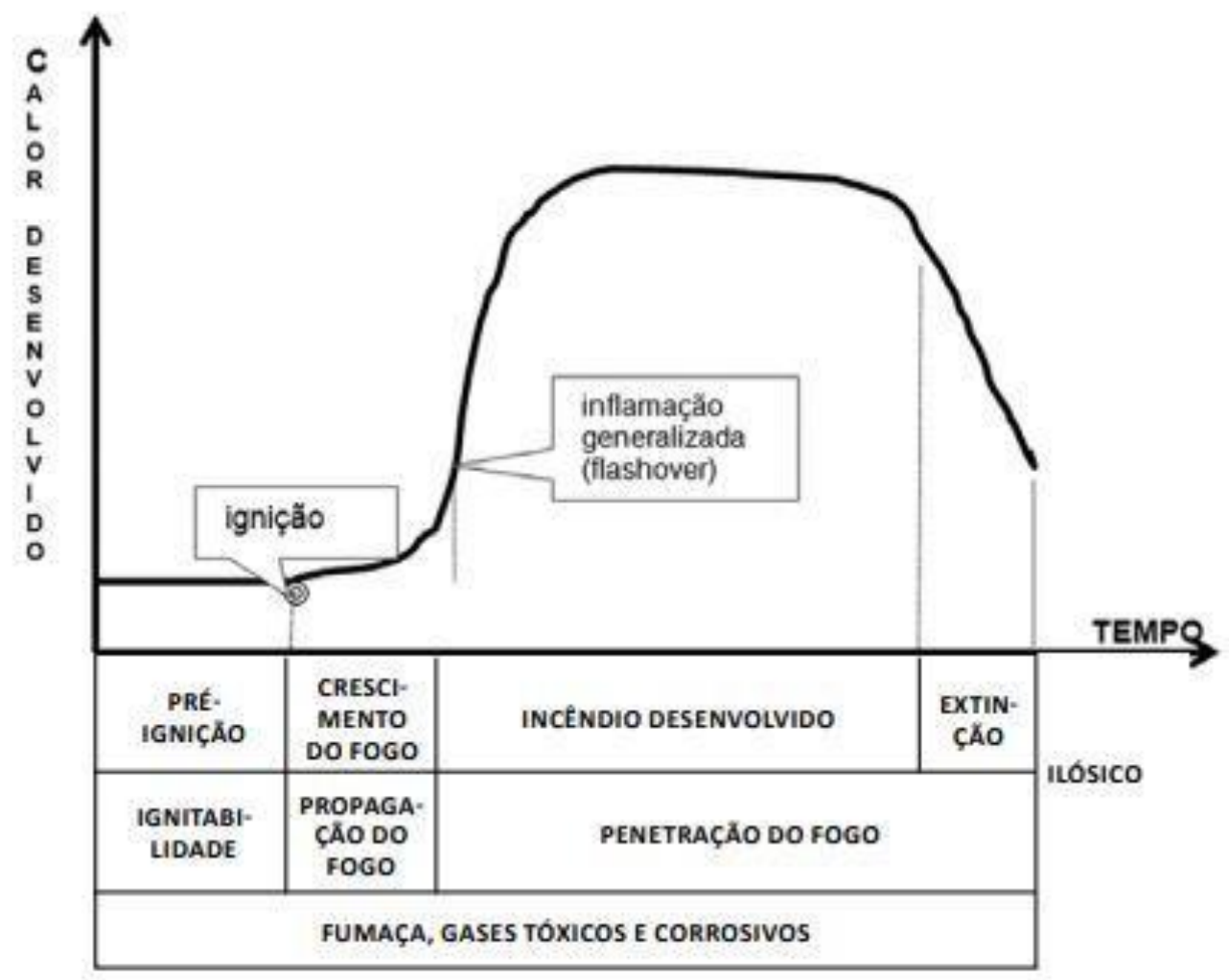

Fonte: ISO/TR3814 (E) Tests to measuring reaction to fire of buildings materials - Their development and application (1989) - tradução nossa

O incêndio produz calor, fumaça e chama e sua evolução possui três fases distintas: na primeira fase, o incêndio tem um crescimento lento até a ignição, na segunda fase, do desenvolvimento do fogo, as chamas começam a crescer e aquecem o ambiente e quando a temperatura atinge em torno de $600^{\circ} \mathrm{C}, \mathrm{o}$ ambiente é tomado por gases e vapores combustíveis desenvolvidos na pirólise dos combustíveis sólidos; se houver líquidos combustíveis, eles irão contribuir com seus vapores e ocorrerá a inflamação generalizada (flashover). Na terceira fase ocorre a extinção do fogo, após exaurir o material combustível, pois ocorre a diminuição da temperatura e das chamas (SEITO, 2008). 


\subsection{Risco de incêndio}

O risco de ocorrência de um incêndio é determinado por fatores inerentes a cada edifício e a segurança desejável para um edifício está diretamente relacionada às categorias de risco e aos objetivos da segurança contra incêndio, bem como aos requisitos funcionais atendidos pelo edifício em estudo. Os fatores que contribuem para a definição do risco de incêndio são basicamente quatro: características da população do edifício, tipo de ocupação, características construtivas do edifício e localização do edifício (MITIDIERI, 2008).

Dentre as características da população do edifício estão inclusas a sua quantidade: a composição da população fixa e flutuante; condições físicas e psicológicas; e a distribuição etária.

Para o tipo de ocupação são verificados: natureza das atividades desenvolvidas no edifício, materiais combustíveis trazidos para o interior do edifício (carga térmica variável), tipos de materiais armazenados e manipulados e tipos de equipamentos existentes no edifício.

Em relação às características construtivas do edifício o risco de incêndio pode ser definido pelos materiais de construção utilizados e técnicas aplicadas, tipo de sistema estrutural adotado, tipo de instalações de serviço existentes, distribuição dos espaços, forma e volume do edifício, número de pavimentos, área total do edifício, área de cada pavimento, aberturas de ventilação, materiais combustíveis destinados a revestimento/acabamento de paredes, tetos e pisos e/ou incorporados aos sistemas construtivos (carga térmica fixa).

Para definir o risco de incêndio em relação à localização do edifício, deve ser observada a situação com relação às divisas do lote, a distância entre edifícios vizinhos, largura das ruas e outras condições de acesso, distância do posto de bombeiros mais próximo, abastecimento de água para o combate e meios de comunicação com o corpo de bombeiros (MITIDIERI, 2008).

\subsection{A prevenção e a proteção contra incêndio}

Definido o risco de incêndio são adotadas medidas preventivas e de proteção que visam à segurança da população, da propriedade e do entorno. 
As medidas preventivas são soluções que devem ser adotadas desde a concepção do projeto para minimizar fatores possíveis para o início do incêndio como a interação com materiais combustíveis e controle das fontes de ignição e o correto dimensionamento das instalações elétricas.

As medidas de proteção são recursos que devem adotados para limitar o crescimento e extinção do fogo no ambiente de origem, limitar a propagação para outros ambientes e edificações vizinhas, assegurar a evacuação segura dos usuários, garantir a eficácia da segurança das operações e equipe de combate e resgate e evitar que a edificação entre em colapso estrutural. Conceitualmente, classificam-se as medidas de proteção contra incêndio de edificações em dois tipos: proteção passiva e proteção ativa.

Dentre as principais medidas de proteção passivas estão:

- Controle de características da reação ao fogo dos materiais incorporados aos elementos construtivos;

- Controle da quantidade de materiais combustíveis incorporados aos elementos construtivos;

- Compartimentação horizontal;

- Compartimentação vertical;

- Resistência ao fogo dos elementos estruturais;

- Resistência ao fogo da envoltória do edifício;

- Estanqueidade da edificação.

O controle das características dos materiais depende da avaliação em relação ao seu comportamento diante do fogo (reação ao fogo), pois há muitas variáveis que estão diretamente associadas aos fatores que definem o risco de incêndio. Por esta avaliação, é possível atuar de maneira preventiva durante o processo produtivo, minimizando os riscos causados pelo incêndio (MITIDIERI, 2008).

A reação ao fogo dos materiais pode ser avaliada de acordo com ensaios padronizados segundo as seguintes características: propagação superficial da 
chama, combustibilidade, inflamabilidade, poder calorífico, densidade ótica específica de fumaça, e toxicidade da fumaça.

Para garantir a proteção contra incêndio, o edifício pode ser dividido em compartimentos corta-fogo para limitar a propagação do fogo e da fumaça além do compartimento de origem do incêndio. Os compartimentos corta-fogo devem ser formados por elementos de compartimentação horizontais e/ou verticais.

Elementos de compartimentação são paredes, lajes ou pisos com propriedades corta-fogo que são utilizados para impedir a propagação do fogo em ambientes contíguos. Os elementos corta-fogo possuem estabilidade, resistência mecânica, estanqueidade e isolamento térmico, impedindo a propagação de gases quentes, fumaça, chamas e calor (CORPO DE BOMBEIROS DA POLÍCIA MILITAR DO ESTADO DE SÃO PAULO, 2018 a).

Por princípio, paredes de separação entre unidades habitacionais contíguas, por exemplo, devem ser resistentes ao fogo e da altura do edifício num plano vertical contínuo da fundação até o telhado.

As paredes exteriores do edifício e as coberturas (telhados) devem resistir adequadamente à propagação do fogo entre edifícios, levando-se em conta a altura, uso e a localização do edifício no lote.

Por isso é muito importante estabelecer as condições a serem atendidas pelos elementos estruturais e de compartimentação que integram as edificações. A Instrução Técnica 08/18 - Segurança estrutural contra incêndio (CORPO DE BOMBEIROS DA POLÍCIA MILITARDO ESTADO DE SÃO PAULO, 2018 b), determina que os materiais devam atender aos Tempos Requeridos de Resistência ao Fogo $^{8}$ (TRRF), para que, em situação de incêndio, seja evitado o colapso

\footnotetext{
${ }^{8}$ Para se avaliar o TRRF são:

a. ensaios específicos de resistência ao fogo em laboratórios;

b. atendimento a tabelas elaboradas a partir de resultados obtidos em ensaios de resistência ao fogo;

c.modelos matemáticos (analíticos) devidamente normatizados ou internacionalmente reconhecidos (IT 08).
} 
estrutural por tempo suficiente para a saída segura das pessoas e o acesso para as operações do Corpo de Bombeiros.

Tempo Requerido de Resistência ao Fogo (TRRF) de um elemento de construção é uma medida da sua capacidade para resistir aos efeitos do fogo em uma ou mais formas, como se segue:

a) A resistência ao colapso, isto é, a capacidade de manter a capacidade de carga (que se aplica ao suporte de carga única elementos resistência mecânica);

b) A resistência à penetração de fogo, ou seja, uma capacidade de manter a integridade do elemento (estanqueidade);

c) A resistência à transferência de calor excessivo, ou seja, uma capacidade de proporcionar um isolamento de altas temperaturas (isolamento).

Além disso, para se evitar a conflagração entre edificações devem ser estabelecidas distâncias seguras e dimensões máximas das aberturas da fachada, pois as chamas, a fumaça e o calor podem se propagar através destas e atingirem outras edificações.

Por exemplo, a madeira quando exposta a uma alta radiação pode se ignizar espontaneamente. Por isso, muitos códigos construtivos exigem proteção da fachada de edificações de madeira, seja por meio de revestimento com materiais incombustíveis (Austrália e Reino Unido) ou madeira com tratamento ao fogo (E.U.A).

Além da proteção passiva, descritas acima, a edificação pode ser provida de sistemas prediais que são ativadas somente em situação de emergência, como os sistemas de detecção, alarme e combate ao fogo. Estas medidas são classificadas como "proteção ativa" (ONO, VALENTIN e VENEZIA, 2008).

\subsection{Desempenho da madeira ao fogo}

Uma das principais limitações do uso da madeira como sistema construtivo para a segurança contra incêndio é a sua natureza combustível. Pinto (2001) 
ressalta que a combustibilidade não é o principal fator a julgar em relação ao desempenho ao fogo de um sistema construtivo de madeira Buchanan (1999), afirma que as construções em madeira podem ser projetadas para ter resistência ao fogo e controle de sua expansão, resultando em estruturas resistentes ao colapso.

Uma peça de madeira de grande espessura exposta ao fogo tem sua superfície ignizada e está propensa a propagação das chamas, porém, após alguns minutos, a camada mais externa da madeira se carboniza tornando-se um isolante térmico, que retém o calor, auxiliando na contenção do incêndio e dependendo da espessura do elemento, esta camada de madeira carbonizada pode evitar que toda a peça seja destruída.

As propriedades térmicas e mecânicas são as que mais influenciam no desempenho da madeira em situação de incêndio. A madeira, por ser um polímero natural, quando exposta a ação do fogo, sofre despolimerização e carbonização, alterando suas propriedades mecânicas conforme o nível de temperatura e tempo de exposição ao calor ao qual foi submetida (VALLE, A. et al., 2012).

\subsubsection{A combustão da madeira}

A combustão é a transformação térmica em presença de oxigênio, em quantidade suficiente pode promover sua decomposição completa por uma fonte externa de calor. Quando esta transformação não tem o aporte suficiente de oxigênio, ou o aporte é controlado, ocorre a carbonização, cujo resíduo sólido é o carvão (FIGUEROA; MOARES, 2009).

Com o aumento da temperatura, a madeira inicia sua degradação por meio de processos químicos e físicos denominados, de forma crescente: pirólise lenta, pirólise rápida, combustão flamejante e combustão incandescente.

Até $200^{\circ} \mathrm{C}$ ocorre um processo endotérmico denominado pirólise lenta, onde a madeira é lentamente aquecida e libera vapor d'água, gases e perde a massa de maneira uniforme. Embora a carbonização ocorra a temperaturas acima de $95^{\circ} \mathrm{C}$, a madeira não entra em ignição. Em um segundo momento, a madeira pode atingir a etapa da pirólise rápida, processo exotérmico, e gases são liberados 
rapidamente. A temperatura que marca a transição da condição endotérmica para exotérmica é considerada como ponto de ignição da madeira. Porém, por se tratar de um material ortotrópico, esse ponto pode variar devido à massa específica, o teor de umidade, a espécie de madeira, as dimensões das peças de madeira, a forma da seção transversal e a intensidade do fluxo de calor (FIGUEROA; MOARES, 2009).

A madeira é um combustível sólido, composto aproximadamente de $85 \%$ de materiais voláteis (PINTO, 2001). Ao atingir temperatura entre $280^{\circ} \mathrm{C}$ a $500^{\circ} \mathrm{C}$, gases combustíveis são liberados como o metano, metanol, formaldeído, ácido fórmico, acético, hidrogênio e alcatrões altamente inflamáveis e que possibilitam a ignição ao serem expostos a uma chama piloto. Os gases se difundem externamente do corpo sólido, formando uma suspensão de gotículas que faz parte da composição da fumaça.

Durante a combustão flamejante, os gases ignizados consomem o oxigênio ao redor e momentaneamente promovem a queima incompleta da madeira, que perde sua massa e transforma-se em carvão (Figura 25). No intervalo de temperatura entre $500^{\circ} \mathrm{C}$ e $1000^{\circ} \mathrm{C}$ ocorre a combustão flamejante, quando as chamas desaparecem e há uma queima luminosa do monóxido de carbono e hidrogênio resultando na incandescência do carvão remanescente.

Figura 25 - Seção carbonizada da madeira

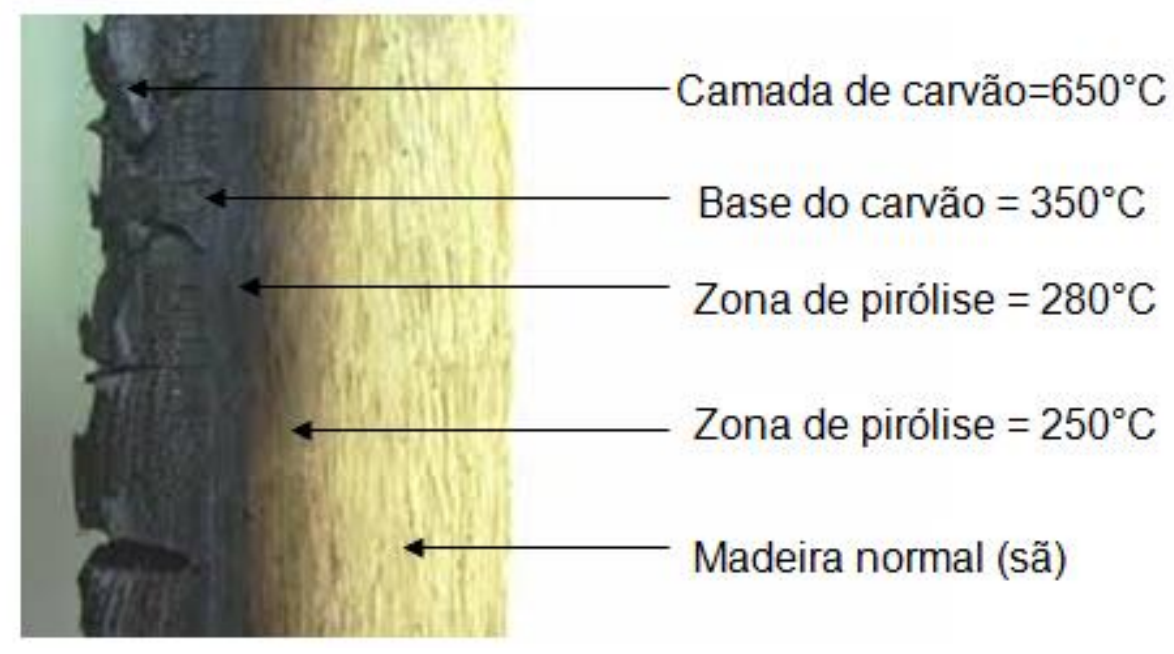

Fonte: Figueroa e Moraes (2009) 
As fases de degradação da madeira são expressas por alguns autores por quatro faixas de temperaturas (PINTO; JUNIOR, 2011) e outros dividem em cinco fases, com suas respectivas faixas de temperaturas (FIGUEROA; MOARES, 2009). No entanto, essas variações são pequenas e as diferenças não são significativas. A Tabela 01 mostra a degradação da madeira dividida em cinco fases e os fenômenos ocorridos durante as respectivas faixas de temperaturas.

Tabela 01 - Fases de degradação da madeira

\begin{tabular}{|c|c|c|}
\hline Fase & Temperatura & Fenômeno \\
\hline I & $\begin{array}{l}\text { Até } 200 \stackrel{\circ}{ } \mathrm{C} \\
\text { (Pirólise lenta) }\end{array}$ & $\begin{array}{l}\text { - Processo endotérmico. } \\
\text { - Liberação de vapor d'água e gases. } \\
\text { - A madeira não se igniza. } \\
\text { - Existência de algumas reações exotérmicas de oxidação. } \\
\text { - Mudança de cor. }\end{array}$ \\
\hline II & $\begin{array}{l}200 \text { a } 280 \stackrel{\circ}{C} \\
\text { (Pirólise rápida) }\end{array}$ & $\begin{array}{l}\text { - Aumento de reação química (catalização) e desprendimento de } \\
\text { gases. } \\
\text { - Ocorrência de reações exotérmicas primárias sem inflamação. } \\
\text { - Temperatura considerada como a temperatura de ignição. } \\
\text { - Fase conhecida como pirólise rápida. }\end{array}$ \\
\hline III & $\begin{array}{l}280 \text { a } 380 \stackrel{\circ}{ } \text { C } \\
\text { (Combustão } \\
\text { flamejante) }\end{array}$ & $\begin{array}{l}\text { - Produção de grande quantidade de destilados, principalmente } \\
\text { ácidos acéticos e metanol. } \\
\text { - O resíduo final dessa fase já é carvão vegetal, mas que ainda } \\
\text { apresenta compostos volatilizáveis em sua estrutura. } \\
\text { - Fase exotérmica. }\end{array}$ \\
\hline IV & $\begin{array}{l}380 \text { a } 500 \stackrel{\circ}{ } \mathrm{C} \\
\text { (Combustão } \\
\text { flamejante) }\end{array}$ & $\begin{array}{l}\text { - Redução da emissão de gases. } \\
\text { - Produção de ácido acético, metanol, alcatrão e diversas substâncias } \\
\text { gasosas condensáveis. } \\
\text { - A perda de massa é da ordem de } 70 \% \text { em relação à massa original. } \\
\text { - Fase exotérmica. }\end{array}$ \\
\hline V & $\begin{array}{l}\text { Acima de } 500 \stackrel{\circ}{\circ} \mathrm{C} \\
\text { (Combustão } \\
\text { incandescente) }\end{array}$ & $\begin{array}{l}\text { - Término da carbonização e início da gaseificação do carvão. } \\
\text { - O carvão é o resíduo principal. } \\
\text { - No interior da madeira permanece a temperatura das fases I, II e II. } \\
\text { - Fase exotérmica. }\end{array}$ \\
\hline
\end{tabular}

Fonte: Figueroa e Moraes (2009)

A formação do carvão é um importante parâmetro para o estudo da madeira sob ação do fogo. O carvão é um subproduto da combustão parcial da madeira, constituído de 20 a $25 \%$ de material volátil, 70 a $75 \%$ de carbono fixo e $5 \%$ de cinzas. Sua condutividade térmica é baixa, $0,04154 \mathrm{~W} / \mathrm{mK}$, e corresponde a $1 / 6 \mathrm{da}$ madeira sã atuando, assim, como isolante térmico das camadas mais internas (PINTO; JUNIOR, 2011). 


\subsubsection{Resistência da madeira ao fogo}

A formação do carvão cuja resistência mecânica é mínima reduz a capacidade de o elemento resistir aos esforços solicitantes. Essa redução é estimada com base em modelos empíricos e teóricos. Pode-se assumir que a seção remanescente seja um material homogêneo ou composto por camadas de diferentes propriedades em função dos gradientes térmicos internos. A partir da superfície até $o$ interior da seção, cada gradiente térmico corresponde à diminuição da resistência e da rigidez na camada em função da temperatura (PINTO; JUNIOR, 2011).

A proporção da madeira carbonizada varia de acordo com a espécie, densidade e o tempo de exposição ao fogo. Entre a porção carbonizada e a madeira sã encontra-se a região intermediária afetada pelo fogo, mas não carbonizada: esta região não deve ser levada em consideração na avaliação da resistência estrutural.

O EN 1995-1: Eurocode 5: Design of timber structures - Part. 1-1: General Common rules and rules for buildings (EUROPEAN COMMITTEE FOR STANDARDISATION - CEN, 2004), por exemplo, assume que todas as peças de madeira têm perda de resistência abaixo da camada carbonizada. A norma europeia considera que essa redução está na ordem de $20 \%$ em relação à madeira intacta. Ela é expressa por um fator de redução que depende do perímetro e da área da seção transversal da peça exposta ao fogo.

Para avaliar a resistência ao fogo das estruturas de madeira é necessário determinar a taxa de carbonização $(\beta)$ que é a razão ou a velocidade na qual a madeira é convertida em carvão. Esta taxa indica a redução da seção transversal dos elementos estruturais (FIGUEROA; MOARES, 2009).

\subsubsection{Espessura de carbonização}

Em vários ensaios de resistência ao fogo, realizados usando curvas de incêndio padrão (ULC / ASTM e ISO), a taxa de carbonização da madeira se apresentou aproximadamente uniforme e muito previsível, dependendo da densidade e teor de umidade da madeira. 
A taxa de carbonização inicial é maior e diminui para uma taxa menor durante a exposição da superfície da madeira ao fogo, mas a taxa de carbonização pode aumentar novamente se a espessura da seção carbonizada se tornar muito pequena. À medida que a carbonização aumenta, a camada crescente de carvão torna-se mais frágil. Esta fragilidade pode causar fissuras que facilitam a passagem de gases combustíveis para a superfície (DRYSDALE, 2011 apud ABU; BUCHANAN, 2017).

Quando a camada de madeira abaixo da camada carbonizada é aquecida acima de $100^{\circ} \mathrm{C}$, a umidade na madeira evapora. Os gradientes de temperatura e umidade em madeira aquecida abaixo da camada de carvão afetam a força e a rigidez de um membro exposto ao fogo. Uma estimativa aproximada da redução da resistência e da rigidez pode ser feita combinando temperaturas previstas da madeira abaixo da camada carbonizada com os efeitos da temperatura na resistência (ABU E BUCHANAN, 2017).

Temperaturas na madeira abaixo da camada carbonizada foram medidas em muitos ensaios e resultados obtidos por Janssens e White (1994 apud ABU; BUCHANAN, 2017) determinaram que existe uma espessura da madeira aquecida logo abaixo da camada carbonizada com cerca de $35 \mathrm{~mm}$, e o restante do núcleo interno permanece à temperatura ambiente, formam uma seção transversal residual. Esta seção transversal residual é capaz de suportar cargas, fornecendo um nível de resistência ao fogo que depende da carga aplicada. A falha estrutural ocorre quando a seção transversal residual é forçada além de seu estado limite último.

A taxa de carbonização dependem das espécies, geralmente, é determinada por meio de ensaios laboratoriais com elementos estruturais em tamanho real, nos quais a elevação da temperatura dos gases quentes segue as prescrições de curvas padrão de incêndio, tais como a das normas ISO 834 (INTERNATIONAL STANDARDIZATION ORGANIZATION, 1999) e ASTM E 119-08a (AMERICAN SOSIETY FOR TEST AND MATERIALS, 2009).

Muitos códigos construtivos especificam uma taxa de carbonização constante na faixa de $0,60-0,75 \mathrm{~mm} / \mathrm{min}$. para madeiras menos densas e de cerca 
de $0,5 \mathrm{~mm} / \mathrm{min}$. para madeiras densas (EN 1995 -1:2004). A taxa de carbonização da madeira laminada colada é geralmente considerada a mesma da madeira sólida. Embora a taxa de carbonização possa ser reduzida após exposição prolongada ao fogo, devido ao aumento da espessura do isolamento camada de carvão, isso geralmente não é reconhecido em códigos construtivos.

No Brasil, a ABNT NBR 7190:1997 não aborda a questão do cálculo estrutural de sistemas construtivos de madeira para incêndio, no entanto a ABNT NBR 15575:2013 especifica que para o projeto estrutural de madeira em situação de incêndio aplica-se o Eurocode 5. O método de seção transversal efetiva recomendado nesta norma usa uma seção retangular um pouco menor que a seção transversal residual para permitir o arredondamento dos cantos, e uma camada de madeira de resistência zero abaixo da linha da camada carbonizada e com as propriedades do material na parte interna do elemento não afetado pela temperatura.

O Eurocode 5 define a profundidade de carbonização em madeira maciça como a distância da superfície exposta carbonizada à linha de carbonização, que é o limite onde ocorre a pirólise da madeira. A linha de carvão é geralmente tomada como isotérmica a $300^{\circ} \mathrm{C}$. A profundidade de carbonização ( $\left.d_{c h a r}, 0\right)$ é definida na seguinte equação para peças estruturais de madeira com espessura de $20 \mathrm{~mm}$ :

Onde:

$$
d_{\text {char }, 0}=\beta_{0} \mathrm{t}
$$

$d_{c h a r, 0 \text { - espessura da camada carbonizada }}$

$\beta_{0}$ - taxa de carbonização unidimensional sob curva padrão de incêndio t - tempo de exposição ao fogo

Em espécies de coníferas e folhosas de origem norte-americana, resultados experimentais obtidos têm demonstrado uma velocidade média de carbonização linear de $0,635 \mathrm{~mm} / \mathrm{min}$. Para o cálculo da profundidade de carbonização recomendam-se dois valores: $0,8 \mathrm{~mm} / \mathrm{min}$. para madeiras secas, de baixa densidade e $0,6 \mathrm{~mm} / \mathrm{min}$. para madeiras coníferas de média densidade. Os modelos assumidos pelas normas admitem uma taxa de carbonização linear (PINTO; JUNIOR, 2011). 
Para espécies cultivadas no Brasil, existem poucos dados. Na literatura são apresentados valores de taxa de carbonização para a espécie Eucalyptus citriodora e Eucalyptus grandis, para teor de umidade aproximado de $24 \%$ e massa específica de 1.060 e $880 \mathrm{~kg} / \mathrm{m}^{3}$ respectivamente, os ensaios realizados obtiveram um valor de $0,58 \mathrm{~mm} / \mathrm{min}$. para ambas as espécies. Em outro estudo ensaios com painel radiante, obtiveram valores de taxa de carbonização de $0,81 \mathrm{~mm} / \mathrm{min}$. para Schizolobium amazonicum com massa específica de $365 \mathrm{~kg} / \mathrm{m}^{3}$ e $12 \%$ teor de umidade (PINTO, 2005; LANDESMANNL et al., 2008 apud FIGUEROA; MORAES, 2009).

No caso da taxa de carbonização para as espécies brasileiras foram necessários ensaios orientados pela ABNT NBR 7190:1997 para a determinação do teor de umidade $(\mu)$, da densidade aparente a $12 \%\left(\rho_{12}\right)$, densidade aparente $(\rho)$ e densidade básica ( $\rho_{\text {bas }}$ ) e para os ensaios de carbonização, as amostras foram expostas à elevação de temperatura segundo a curva de aquecimento proposta pela norma ASTM E 119:1995 (PINTO; JUNIOR, 2011).

Outro fator importante a ser levado em conta na seção residual efetiva é o arredondamento nas quinas do elemento estrutural, resultando na exposição das duas faces (Figura 26). Em vigas e pilares, esse arredondamento apresenta uma perda considerável das quinas destes elementos estruturais e, portanto, deve ser prevista em cálculo por norma (PINTO; JUNIOR, 2011).

Todos os ensaios de fogo de grandes seções de madeira retangulares mostram algum arredondamento dos cantos, porque os cantos são submetidos à transferência de calor de suas superfícies. A maioria das normas técnicas, incluindo Eurocode 5, usa a relação simples pela qual o raio do arredondamento é igual à profundidade da camada carbonizada. Se o arredondamento de cantos for levado em consideração, as propriedades da seção serão afetadas dependendo do tamanho do elemento e/ou componente (ABU; BUCHANAN, 2017).

Quando o arredondamento das quinas e as fissuras do elemento estrutural são levados em conta é denominado como taxa de carbonização nominal $\left(\beta_{n}\right)$ que 
deve ser considerada em tempo constante, e a espessura de carbonização é calculada conforme a seguinte a equação expressa no Eurocode 5 :

Onde:

$$
d_{c h a r, n}=\beta_{n} t
$$

dchar,n - espessura da camada carbonizada com efeito de arredondamento dos cantos do elemento estrutural

$\beta_{n}$ - taxa de carbonização nominal sob curva padrão de incêndio com efeito de arredondamento e fissuras dos cantos do elemento estrutural

t - tempo de exposição ao fogo

Figura 26 - Espessura de carbonização dchar,0 e espessura carbonização nominal dchar, $n$ (efeito do arredondamento de canto)

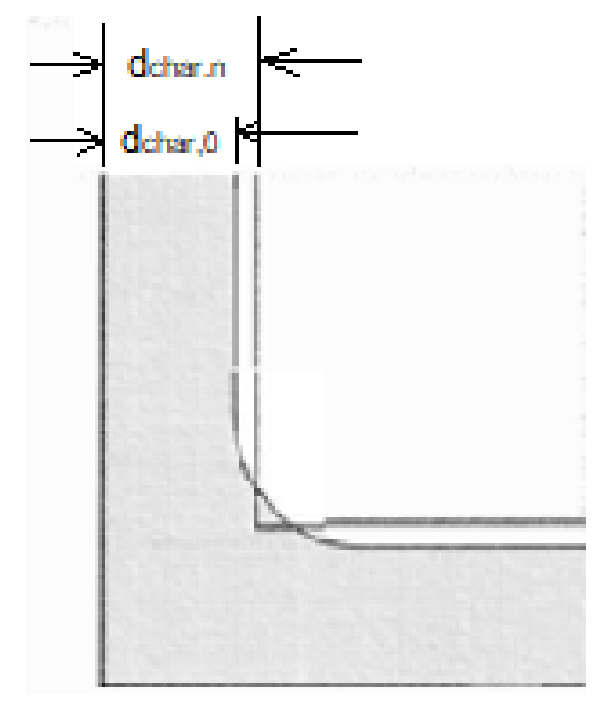

Fonte: Eurocode 5 (2004)

Para o cálculo estrutural, quando adota-se $\beta_{0}$ (taxa de carbonização unidimensional), o efeito de arredondamento na quina da peça estrutural não é considerado, mas ao adotar $\beta_{n}$ (taxa de carbonização nominal) o arredondamento dos cantos é considerado e o raio do arredondamento é igual à espessura da camada carbonizada.

Para produtos derivados da madeira o Eurocode 5 apresenta valores de taxa de carbonização $\beta_{0}$ (unidimensional) e $\beta_{n}$ (nominal) para densidade de $450 \mathrm{~kg} / \mathrm{m}^{3} \mathrm{e}$ espessura de $20 \mathrm{~mm}$, conforme Tabela 02 abaixo: 
Tabela 02 - Taxa de carbonização $\beta_{0}$ e $\beta_{n}$ da madeira, LVL, revestimento e produtos derivados da madeira

\begin{tabular}{l|c|c}
\hline \multicolumn{1}{c|}{} & $\begin{array}{c}\beta_{0} \\
\mathrm{~mm} / \mathrm{min} .\end{array}$ & $\begin{array}{c}\beta_{n} \\
\mathrm{~mm} / \mathrm{min} .\end{array}$ \\
\hline a) Coníferas & 0,65 & 0,7 \\
MCL com densidade de $\geq 290 \mathrm{~kg} / \mathrm{m}^{3}$ & 0,65 & 0,8 \\
Madeira maciça com densidade de $\geq 290 \mathrm{~kg} / \mathrm{m}^{3}$ & & \\
\hline b) Folhosas & 0,65 & 0,7 \\
Madeira maciça ou MLC com densidade de $\geq 290 \mathrm{~kg} / \mathrm{m}^{3}$ & 0,50 & 0,55 \\
Madeira maciça ou MLC com densidade de $\geq 450 \mathrm{~kg} / \mathrm{m}^{3}$ & 0,50 \\
\hline c) LVL & 0,65 & 0,7 \\
Densidade de $\geq 480 \mathrm{~kg} / \mathrm{m}^{3}$ & & - \\
\hline d) Painéis & $0,9^{\mathrm{a}}$ & - \\
Revestimento de madeira & $1,0^{\mathrm{a}}$ & - \\
Compensado de madeira & $0,9^{\mathrm{a}}$ & - \\
Painéis de produtos derivados da madeira &
\end{tabular}

a Os valores se aplicam a densidade de $450 \mathrm{~kg} / \mathrm{m}^{3}$ e para painéis de espessura de $20 \mathrm{~mm}$.

Fonte: EN 1995-1-2 (2004) (English): Eurocode 5: Design of timber structures - Part 1-2: General - Structural fire design

O cálculo da taxa de carbonização para os produtos derivados segue o estabelecido nas normas, a saber: EN 309:1992 Wood particleboards - Definition and classification; EN 313-1: 1996 Plywood Classification and terminology. Part 1: Classification; EN 300:2006 Oriented strand boards (OSB) - Definition, classification and specifications e EN 316:2009 Wood fibreboards - Definition, classification and symbols.

\subsubsection{Espessura de carbonização da madeira protegida}

Para os painéis protegidos a aplicação de uma camada protetora em superfícies de madeira pode retardar o início da carbonização $\left(t_{c h}\right)$ e pode reduzir a taxa de carbonização abaixo da camada carbonizada. No entanto, mesmo que não haja carbonização abaixo da camada carbonizada, a madeira protegida pode ser aquecida, levando a uma taxa mais rápida de carbonização quando a camada protetora se desprende (tempo de queda tf da proteção) como mostra a Figura 27 (ABU; BUCHANAN, 2017). 
Figura 27 - Taxa de carbonização para elementos não protegidos e protegidos com falha na proteção

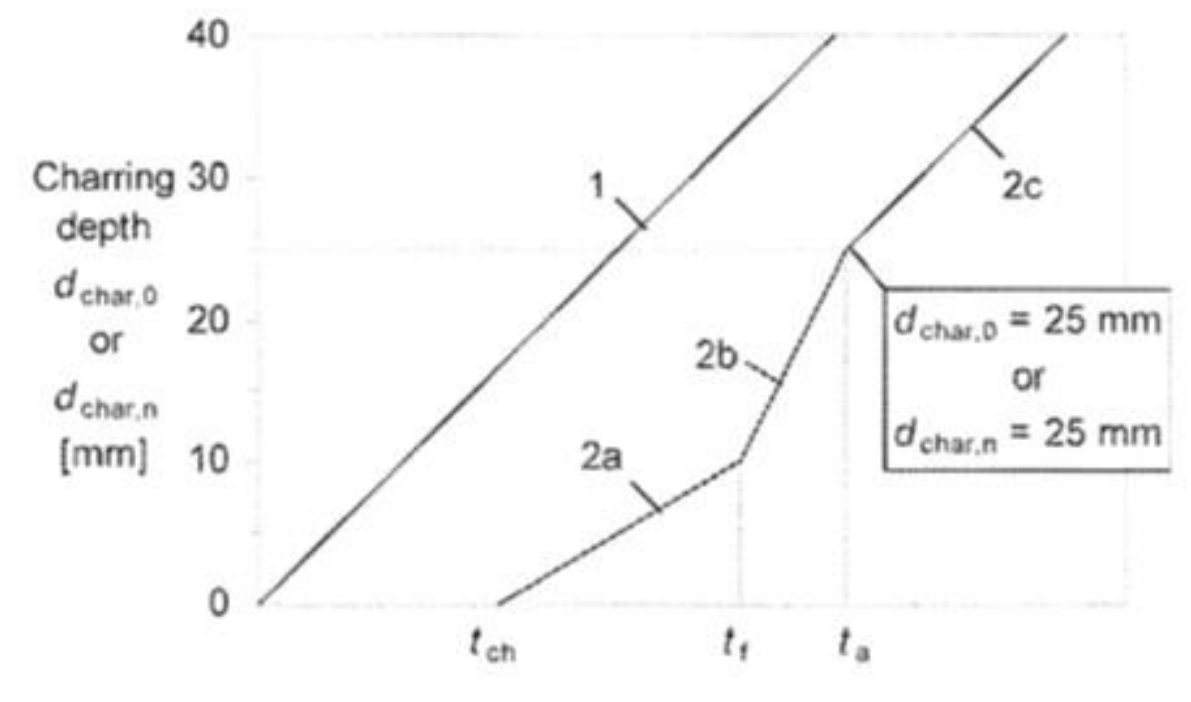

Fonte: Eurocode 5 (2004)

Legenda:

1 - Relação entre elementos não protegidos e protegidos e o tempo de exposição ao fogo para a taxa de carbonização normal $\left(\beta_{0}\right)$ ou nominal $\left(\beta_{n}\right)$.

2 - Relação para o início da taxa de carbonização do elemento protegido

antes da falha da proteção.

2a - Início da carbonização $t_{c h}$ na redução da taxa quando ainda há proteção.

$2 b$ - Depois da falha da proteção, aumento da taxa de carbonização.

2c - Depois da carbonização atingira a profundidade de $25 \mathrm{~mm}$ a taxa de carbonização tende a diminuir.

O Eurocode 5 assume que a taxa de carbonização sob uma camada protetora é metade da taxa de carbonização de madeira desprotegida, mas esta taxa pode aumentar em até quatro vezes quando ocorre o desprendimento da proteção, até a faixa carbonizada atingir uma profundidade de $25 \mathrm{~mm}$ na seção do elemento/ componente (Figura 27).

Outro fator a considerar é que qualquer grande área de madeira exposta contribuirá para a carga fixa combustível no ambiente, isso também se aplica para superfícies de madeira não estruturais.

No entanto, a taxa de carbonização lenta e previsível da madeira significa que apenas a camada mais externa do painel (desde que tenha no mínimo de 25 $\mathrm{mm}$ de espessura) precisa ser considerada no cálculo da carga combustível. 
Seguindo este procedimento, fica claro que os painéis CLT com o melhor desempenho ao fogo serão aqueles com espessas camadas de madeira, especialmente a camada na face exposta ao fogo.

\subsubsection{Tratamentos da madeira ao fogo}

Diversos produtos químicos retardadores de fogo estão disponíveis para o tratamento de madeira para reduzir sua combustibilidade. O principal objetivo de tais tratamentos químicos é retardar a ignição a fim de dificultar a propagação da chama sobre a superfície da madeira. A impregnação por pressão de produtos químicos é considerada mais eficaz do que a pintura de superfície, o processo de impregnação é semelhante ao utilizado para a aplicação de produtos químicos resistentes à deterioração.

No Brasil, atualmente, encontram-se produtos desenvolvidos exclusivamente para a proteção contra o fogo em madeiras, como retardante antichamas, tinta intumescente e verniz retardante. Segundo um dos representantes no país de produtos para proteção passiva, a solução retardante antichamas é um produto incolor, inodoro, atóxica e recomendada para materiais onde há a necessidade de se evitar a ignição. Já a tinta intumescente possui a mesma aparência e acabamento das pinturas convencionais, no entanto, ao entrar em contato com temperaturas superiores a $200^{\circ} \mathrm{C}$, se expande por múltiplas vezes, protegendo o substrato da reação das elevadas temperaturas do fogo. O verniz retardante, por outro lado, também usado para aumentar a proteção da reação ao fogo, apresenta acabamento transparente e fosco, para uso interno ou externo e onde há a necessidade de resistência máxima à abrasão, também podendo ser utilizado em pisos de madeira, paredes e forros, também são adequados ao uso em superfícies de madeira com película melamínica, escadas, divisórias, etc.

De acordo com o mesmo representante todos seus produtos são ensaiados em laboratórios nacionais e internacionais, e atendem às normas técnicas nacionais e todas as exigências das legislações vigentes. Os produtos retardantes e revestimentos são a base água, são praticamente inodoros, de baixa toxicidade, transparente (nos casos dos retardantes e vernizes) e não deixam manchas e nem resíduos permanentes nos materiais tratados $\left(\mathrm{CKC}^{\circledR}, 2019\right)$. 
Tratamentos da madeira por meio de revestimentos, tintas e vernizes aplicados manualmente ou por pressão a vácuo são considerados como uma medida preventiva, porém alguns estudos demonstraram que estes produtos não melhoraram a resistência ao fogo dos elementos de madeira, como veremos mais à frente (ABU; BUCHANAN, 2017).

\subsection{Projeto estrutural de madeira contra incêndio}

Antes de fazer qualquer projeto, é essencial estabelecer objetivos claros e determinar a severidade do fogo no projeto. De acordo com Abu e Buchanan (2017) o projeto pode ser realizado usando o estado limite de utilização ou estado limite último. As principais diferenças de projeto estrutural com resistência ao fogo em comparação com o projeto estrutural em temperatura normal são que, no momento de um incêndio:

- As cargas de estado limite de incêndio são menores. Forças internas e deformações podem ser induzidas por expansão térmica diferencial;

- As interações com a estrutura circundante ocorrem quando os membros tentam se expandir. A força dos materiais pode ser reduzida por temperaturas elevadas;

- As áreas transversais podem ser reduzidas por carbonização;

- As deflexões não são importantes (a menos que afetem a resistência);

- Diferentes mecanismos de falha precisam ser considerados.

Os fatores acima podem variar para diferentes materiais. Por exemplo, a Figura 28 mostra um componente de madeira, onde as tensões aumentam constantemente (sob carga constante) devido à perda de seção por carbonização. A resistência do material só diminui ligeiramente devido a temperaturas elevadas dentro do componente. Como antes, a falha ocorre quando o estado limite no componente excede a resistência do material.

A verificação do projeto quanto à resistência durante o incêndio requer que as cargas aplicadas sejam inferiores à capacidade de carga da estrutura, para a duração do tempo do incêndio de projeto. 
Figura 28 - Falha da resistência

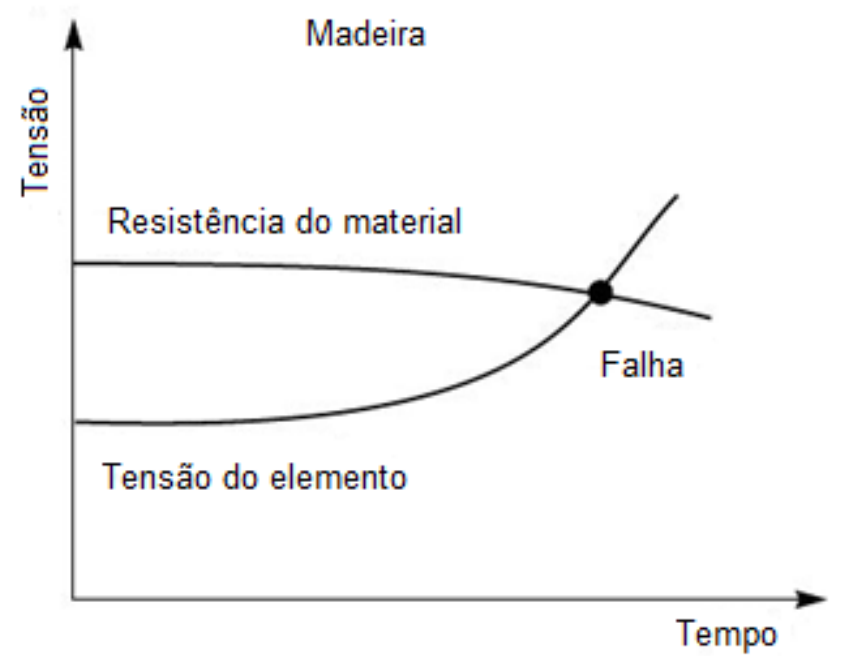

Fonte: Abu e Buchanan (2017) tradução nossa

O fator de redução de resistência é responsável pela incerteza nas estimativas de resistência do material e tamanho da seção. $O$ incêndio de projeto é baseado na resistência esperada mais provável. Códigos nacionais e internacionais especificam um fator de redução de força de $\Phi$ fogo = 1,0. Nos Eurocódigos, o fator de segurança parcial yM também é igual a 1,0 para o incêndio de projeto.

Tanto na América do Norte como na Europa, a equação para o projeto estrutural sob condições de incêndio é dada por:

Onde:

$$
U_{\text {fire }}^{*} \leq R_{\text {fire }}
$$

$U^{*}$ fire = carga durante o incêndio

$R$ fire = capacidade da carga nominal durante o incêndio

Todos os métodos de cálculo para o projeto estrutural de madeira em situação de incêndio são baseados em ensaios de curva de incêndio padrão (ULC / ASTM e ISO).

Entretanto para incêndios reais, a quantidade de ventilação no compartimento de incêndio pode variar a taxa de carbonização e isto deve ser 
levado em conta no projeto de incêndio, considerando as aberturas externas do edifício.

Além disso, um grande problema com o projeto de estruturas de painéis maciços de madeira para incêndios reais é que não se pode prever que os elementos e/ou componentes de madeira irão parar de carbonizar depois da inflamação generalizada do ambiente, mesmo se a espessura da camada de resistência residual for suficiente para manter a estabilidade estrutural da edificação no final do incêndio. 


\section{CÓDIGOS E NORMAS TÉCNICAS CONSTRUTIVAS VISANDO À SEGURANÇA CONTRA INCÊNDIO}

Ao longo da história, inúmeros incêndios dos mais variados níveis de devastação foram registrados, muitos destruindo cidades e com a perda de muitas vidas. Alguns destes incidentes deram origem a uma regulamentação específica, como o grande incêndio de Londres de 1666, que destruiu 1300 propriedades e culminou no primeiro código construtivo de Londres - o London Building Act (FIRE SAFETY IN BUILDINGS, 1996).

Na América do Norte, após incêndios em Quebec (1866), Chicago (1871), Boston (1872), Saint John (1877), Ottawa-Hull (1900), Baltimore (1904), Toronto (1904) e San Francisco (1906), as leis municipais de construção adotaram medidas para a proteção ao fogo que foram base para muitos códigos de segurança contra incêndio como o National Fire Code of Canada - NFCC (FIRE SAFETY IN BUILDINGS, 1996).

Atualmente, na Europa e em países como Estados Unidos, Canadá e Japão, a segurança contra incêndio é encarada como uma ciência, portanto há imensa pesquisa em desenvolvimento e ensino nesta área. Novas tecnologias que estão sendo desenvolvidas têm contribuído para o conhecimento da prevenção e proteção ao fogo (SEITO, 2008).

Legislações e códigos de segurança contra incêndio nestes países e em outros como Austrália vêm sendo desenvolvidos para edificações mais complexas e para novos sistemas construtivos.

Estados Unidos e Canadá, com tradição construtiva em madeira, têm leis mais específicas para habitações construídas com esse tipo de sistema construtivo, pois há anos estes países desenvolvem pesquisas, tecnologias, equipamentos e produtos para garantir a segurança ao fogo nas edificações. Países como Reino Unido e Austrália também estão tomando medidas e desenvolvendo pesquisas na área da segurança contra incêndio devido à introdução de novos sistemas construtivos de madeira e derivados para adequá-los e garantir a qualidade e segurança para as edificações construídas com estes tipos sistemas. 
Vários países que têm introduzido o CLT em seu mercado de construção nacional e têm produzido normas técnicas ou estão inserindo especificações em seus códigos construtivos voltados para a segurança contra o incêndio, para os novos sistemas construtivos de madeira.

\subsection{Requisitos gerais de segurança contra incêndio}

A maioria dos códigos de construção especificam praticamente os mesmos requisitos para as edificações residenciais em relação à segurança contra incêndio. Em geral, os requisitos que devem ser atendidos pelas edificações são manter a estabilidade estrutural, evitar a propagação do fogo e fumaça interna e externa, prover condições seguras para evacuação e acesso à brigada de incêndio.

Os códigos internacionais geralmente especificam a resistência ao fogo mínima para os elementos e componentes de construção incorporados de acordo com o uso da edificação e a função do elemento.

Em edificações de madeira as barreiras arquitetônicas são recursos utilizados que visam à proteção dos elementos e componentes da edificação quando expostos ao fogo. Estas barreiras evitam a propagação do fogo na edificação contribuindo com a estabilidade da mesma e tempo para evacuação segura dos usuários.

As barreiras arquitetônicas são usualmente utilizadas em sistemas de estruturas leves (light-frame) entre componentes e/ou elementos. Também para os sistemas de painéis de madeira maciça barreiras arquitetônicas são usadas entre ambientes e edificações.

Por exemplo, em países como Austrália, Estados Unidos e Canadá são muito utilizados os sistemas de estruturas leves, entre os elementos deste sistema são formadas várias cavidades (espaços vazios). Quaisquer espaços vazios na construção devem ser vedados e subdivididos por barreiras de proteção para inibir a propagação do fogo e produtos da combustão, a fim de reduzir o risco de falha estrutural. 
As barreiras de proteção devem estar localizadas entre elementos e nas junções entre o conjuntos de piso / lajes de paredes resistentes ao fogo ou paredes externas: também devem ser instaladas de modo que sejam ajustadas e possam suportar a expansão térmica e o movimento estrutural sem a perda da proteção contra fogo e fumaça.

Juntas de dilatação, conectores e similares entre elementos e componentes construtivos, também devem ser resistentes ao fogo em relação à integridade, estanqueidade e isolamento.

As aberturas nos elementos construtivos devem ser adequadamente protegidas, a fim de manter a integridade do elemento (obstruindo o fogo). Em torno do perímetro de aberturas de portas e janelas de elementos onde é exigida a resistência ao fogo, a barreira de proteção pode ser a própria estrutura ou a moldura dos caixilhos.

Tubulações que passam através de elementos de compartimentação devem ser seladas com dispositivos corta-fogo (selos corta-fogo), protegidas (luvas) e ter um diâmetro limitado. Onde não for utilizado um sistema de vedação próprio, um selo corta-fogo pode ser usado para proteger o furo da tubulação, mantendo a abertura na dimensão mínima possível.

Se uma edificação for equipada com um sistema de chuveiros automáticos, a intensidade e extensão de um incêndio poderão ser reduzidas.

Os códigos também estabelecem as condições a serem atendidas pelos materiais de acabamento e de revestimento empregados nas edificações, para que, na ocorrência de incêndio, restrinjam a propagação de fogo e o desenvolvimento de fumaça.

A seguir, é apresentado um resumo de como a Austrália, o Reino Unido e os Estados Unidos da América tratam da questão da segurança contra incêndio para edifícios residenciais, isolados, assobradados e geminados em seus códigos construtivos, no que se refere ao tema aqui tratado. 


\subsection{Códigos construtivos e segurança contra incêndio}

\subsubsection{Austrália}

O Building Code of Australia (BCA), código nacional construtivo australiano foi criado a partir de requisitos de desempenho para a construção de edifícios baseado numa hierarquia de orientação e níveis de conformidade que as edificações, os elementos e os sistemas devem atender. As exigências do BCA podem ser satisfeitas pelos requisitos prescritivos (Deemed to Satisfy Solution) ou por uma solução alternativa com base no desempenho (Performance Solution) equivalente ao requisito determinado através da aprovação de um dos seguintes métodos de avaliação ou uma combinação destes:

a) Evidência documental (Documentary Evidence);

b) Métodos de verificação (Verification Methods);

c) Julgamento de um especialista técnico e,

d) Comparação com o Deemed to Satisfy Provisions (ABCA, 2018).

\section{Classificação dos edifícios}

Cada parte do edifício deve ser construída de maneira apropriada de modo a atingir os requisitos do BCA, usando materiais, produtos, métodos construtivos adequados ao uso, atendendo aos critérios dos métodos de avaliação. As classificações do $B C A$ designadas para edificações residenciais são representadas na Tabela 03.

Para este estudo serão verificados alguns detalhes construtivos que visam à segurança contra incêndio do $B C A$ para edifícios residenciais isolados, associados (geminadas) e unidades sobrepostas, classificadas como Classes 1, 2 conforme 0 Quadro 1.

Quadro 1 - Classificação das edificações residenciais

\begin{tabular}{c|c|c|c}
\hline Classe & $\begin{array}{c}\text { Sub } \\
\text { classe }\end{array}$ & Tipo & Exemplo \\
\hline \multirow{3}{*}{ Classe 1 } & Classe 1 a & Casa isolada & $\begin{array}{c}\text { casa geminada, uma casa com } \\
\text { terraço, uma moradia ou uma } \\
\text { unidade de moradia }\end{array}$ \\
\cline { 2 - 4 } & Classe 1 b & $\begin{array}{c}\text { grupo de duas ou mais } \\
\text { edificações anexas, cada uma } \\
\text { sendo um edifício: }\end{array}$ & $\begin{array}{c}\text { uma pensão, guest house, hostel } \\
\text { ou similar }\end{array}$ \\
\hline
\end{tabular}




\begin{tabular}{|c|c|c|}
\hline & \multirow{2}{*}{$\begin{array}{c}\text { não mais de } 12 \text { pessoas } \\
\text { ter uma área total de todos os } \\
\text { pisos não superior a } 300 \mathrm{~m}^{2}\end{array}$} & \\
\hline & & \\
\hline & \multicolumn{2}{|c|}{$\begin{array}{c}\text { quatro ou mais habitações individuais localizadas num lote e } \\
\text { utilizadas para alojamento de férias de curta duração. }\end{array}$} \\
\hline Classe 2 & $\begin{array}{l}\text { edificação contendo duas ou } \\
\text { mais unidades residenciais }\end{array}$ & $\begin{array}{c}\text { residências, cômodos ou } \\
\text { dormitórios que estão inseridos } \\
\text { em edificações de Classe } 3,5,6 \text {, } \\
7,8 \text { ou } 9\end{array}$ \\
\hline
\end{tabular}

Fonte: (www.abcb.gov.au)

\section{Segurança estrutural}

$O B C A$ determina que os elementos de construção (como paredes externas e de compartimentação entre unidades) e seus componentes devem ser resistentes ao fogo e não combustíveis, incluindo o revestimento da fachada, a estrutura e o isolamento do pavimento e a estrutura do piso de poços de elevador (quando houver) como segue a Tabela 03.

Tabela 03 - Resistência dos elementos construtivos

\begin{tabular}{l|c|c}
\hline \multicolumn{1}{c}{ Elemento de Construção } & FRL estrutural/estanqueidade/isolamento \\
\cline { 2 - 3 } & Classe 1 & Classe 2 \\
\hline Paredes externas & $60 / 60 / 60$ & $90 / 60 / 30$ \\
\hline Paredes internas & $60 / 60 / 60$ & $90 / 60 / 30$ \\
\hline Laje piso & $30 / 30 / 30$ & $30 / 30 / 30$ \\
\hline Laje cobertura & $60 / 60 / 60$ & $90 / 60 / 30$ \\
\hline Paredes de fechamento de escadas & $\mathrm{NA}^{*}$ & $90 / 90 / 90$ \\
\hline
\end{tabular}

Fonte: (www.abcb.gov.au)

* Não se aplica

Para especificar a adequação estrutural, integridade e isolamento, o Fire Resistance Level (FRL), período de classificação nominal, em minutos, é usado para indicar a resistência dos elementos construtivos. $F R L$ é determinado pela curva de temperatura de tempo padrão estabelecido na norma AS 1530.4 (STANDARD AUSTRALIAN, 2005).

Paredes externas com ou sem aberturas (incluindo empena) de um edifício, devem ser resistentes ao fogo e estar sob coberturas ou beirais de materiais não combustíveis, com FRL especificado na Tabela 04, ser de alvenaria e não ter espessura inferior a $900 \mathrm{~mm}$. As aberturas não devem ocupar mais de $1 / 3 \mathrm{da}$ 
área da parede externa: janelas ou outro elemento devem ter $F R L$ não inferior a - / 60 / - ou terem portas com núcleo sólido de espessura não inferior a 35 mm.

\section{Compartimentação}

Paredes internas de compartimentação entre edificações de classe 1, ou classe 10a (garagem) devem ser construídas conforme mostra a Figura 29.
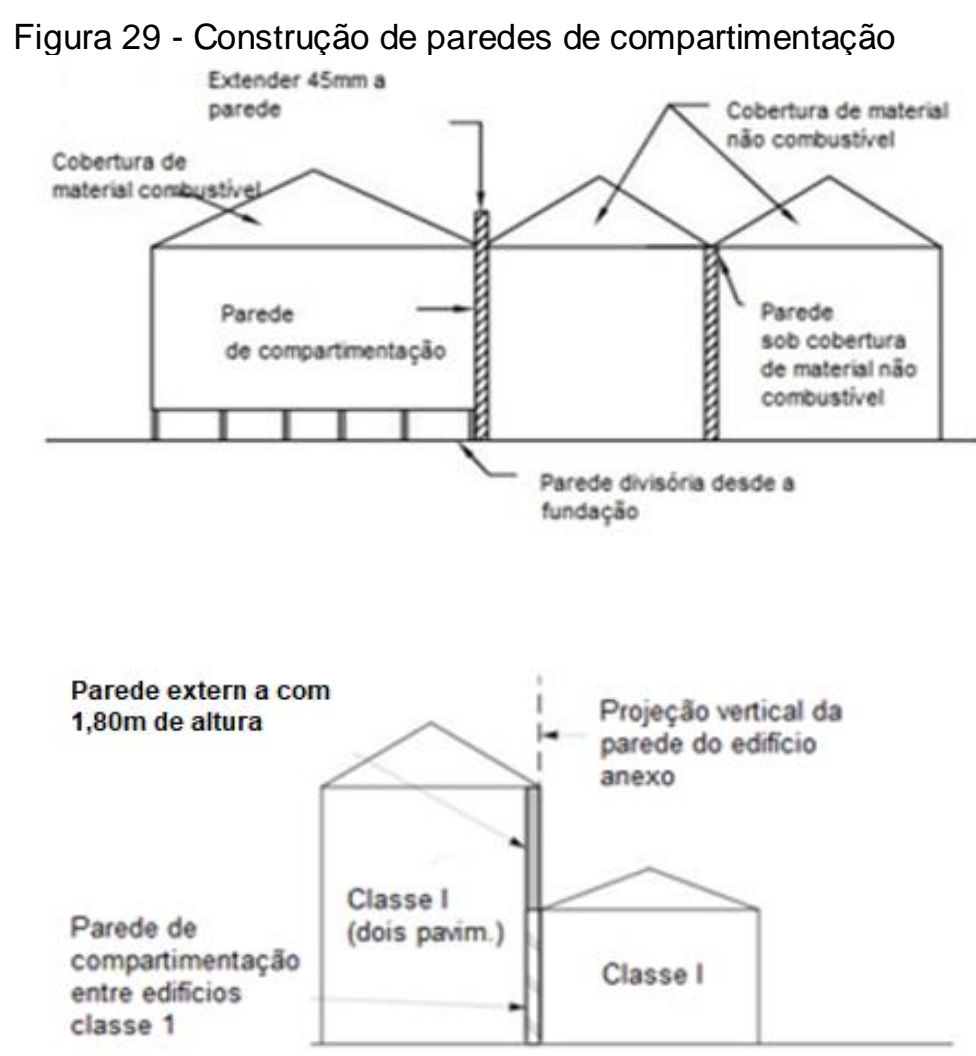

Fonte: ABCB (2018) tradução nossa

As barreiras de proteção horizontais e verticais dentro do vão entre pisos, lajes ou paredes, devem ser protegidas ou ter espessuras mínimas conforme a resistência requerida para a função do elemento, conforme a Tabela 4:

Tabela 4 - FRL da barreira de proteção

\begin{tabular}{l|c|c|c}
\hline TRRF requerido & $-/ 60 / 60$ & $-/ 90 / 90$ & $-/ 120 / 120$ \\
\hline Barreira de requerida FRL & -1 & -1 & $-/ 60 / 60$ \\
\hline Espessura mínima da madeira & $45 \mathrm{~mm}$ & $45 \mathrm{~mm}$ & $55 \mathrm{~mm}$ \\
\hline Espessura mínima da lã mineral & $45 \mathrm{~mm}$ & $45 \mathrm{~mm}$ & $60 \mathrm{~mm}$ \\
\hline
\end{tabular}

Fonte: ABCB (2018) tradução nossa

Nota: As espessuras mínimas devem ser medidas na direção do fluxo de calor. 
Tintas e revestimentos retardadores de fogo não devem ser usados para alcançar conformidade exigida quanto à proteção ao fogo para elementos e/ou componentes de madeira.

As paredes de compartimentação da classe 1 também não devem ser atravessadas por elementos de madeira ou outro material combustível, exceto por sarrafos de telhado com dimensões máximas de $75 \times 50 \mathrm{~mm}$ ou subcobertura para telhado.

\section{Instalações de serviços}

Para a instalação de serviços em paredes e lajes qualquer abertura para a passagem deve ter $F R L$ não inferior a - / 60/60 e distância máxima de $50 \mathrm{~mm}$ de qualquer outro serviço. A abertura não deve ser maior em corte transversal do que $2000 \mathrm{~mm}{ }^{2}$ se apenas um único cabo for acomodado e o espaço entre o cabo e a parede não deve ser maior que $15 \mathrm{~mm}^{2}$ ou $500 \mathrm{~mm}^{2}$ e deve ser protegida com fibra mineral ou outro material resistente ao fogo.

Interruptor elétrico, tomada, soquete ou similar deve ser instalado de modo que a abertura para a instalação não deve estar localizada em frente a qualquer ponto dentro de $300 \mathrm{~mm}$ horizontalmente e/ou $600 \mathrm{~mm}$ verticalmente de qualquer outra abertura para a instalação no lado oposto da mesma parede e não estender além da metade da espessura da parede.

Para instalações da classe 2, as tubulações que atravessam um elemento que exige isolamento ou uma resistência ao fogo, devem estar em conformidade com qualquer um dos seguintes itens:

a) o serviço é um sistema de tubulação de metal (excluindo vedações de tubos ou similares);

b) qualquer elemento de construção combustível não deve estar localizado a $100 \mathrm{~mm}$ do serviço;

c) o serviço não deve estar localizado em uma saída;

d) não conectar mais de dois compartimentos, com exceção pela passagem de serviços desde que sejam resistentes ao fogo; e

e) não contém gás inflamável ou líquido combustível. 
O material utilizado para a selagem das passagens de serviço deve ser concreto, fibra mineral ou cerâmica de alta temperatura, ou outro material que mantenha a temperatura acima de $1120^{\circ} \mathrm{C}$ conforme o método de ensaio ISO 540:2008.

\section{Distâncias entre edifícios}

Para manter distâncias seguras entre edifícios contra a propagação do fogo, é feito o cálculo do fluxo de calor do elemento que indicará a distância mínima a ser adotada. As distâncias mínimas para a classe 1 são:

a) $900 \mathrm{~mm}$ de um limite não adjacente a um alinhamento rodoviário ou outro espaço público; ou

b) $1.800 \mathrm{~mm}$ de outro edifício no mesmo lote que não seja um edifício de classe 10a ou uma parte separada do mesmo edifício de classe 1.

A distância entre edifícios de diferentes alturas é medida a partir da parede externa com a maior elevação, perpendicularmente a um ponto em que intercepta uma projeção vertical acima da parede da edificação de menor altura (Figura 30).

Figura 30 - Edificações de diferentes alturas

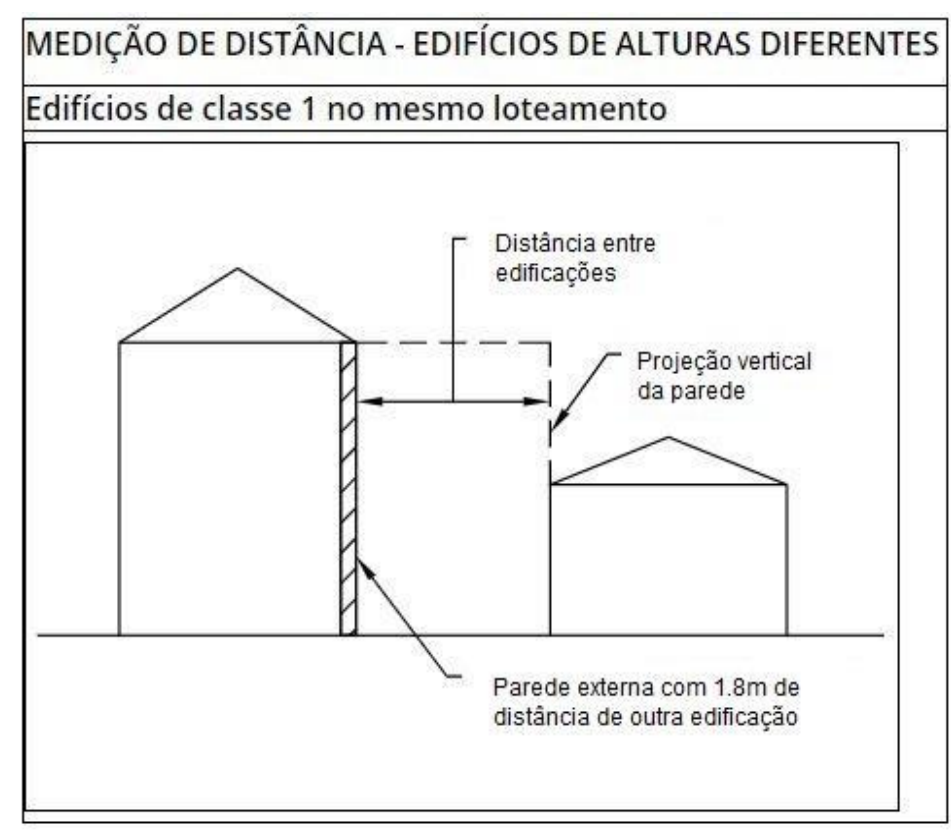

Fonte: $A B C B(2018)$ tradução nossa 
Para a classe 2 as distâncias a serem adotadas seguem a Tabela 05 abaixo:

Tabela 5 - Distância entre paredes externas e aberturas associadas em diferentes compartimentos de incêndio

\begin{tabular}{l|c}
\hline \multicolumn{1}{c|}{ Ângulo entre paredes } & Distância mínima \\
\hline $0^{\circ}$ (paredes opostas) & $6 \mathrm{~m}$ \\
\hline mais de $0^{\circ}$ a $45^{\circ}$ & $5 \mathrm{~m}$ \\
\hline mais de $45^{\circ}$ a $90^{\circ}$ & $4 \mathrm{~m}$ \\
\hline mais de $90^{\circ}$ a $135^{\circ}$ & $3 \mathrm{~m}$ \\
\hline mais de $135^{\circ}$ a menos de $180^{\circ}$ & $2 \mathrm{~m}$ \\
\hline $180^{\circ}$ ou mais & nada \\
\hline
\end{tabular}

Fonte: ABCB (2018) tradução nossa

Elementos destinados para a passagem de luz natural, como clarabóias ou similar na cobertura combustível, devem obrigatoriamente ser revestidos por material não combustível, ter área não superior a $20 \%$ da cobertura e dispostos de acordo com a Figura 31.

Figura 31 - Distribuição de iluminação natural

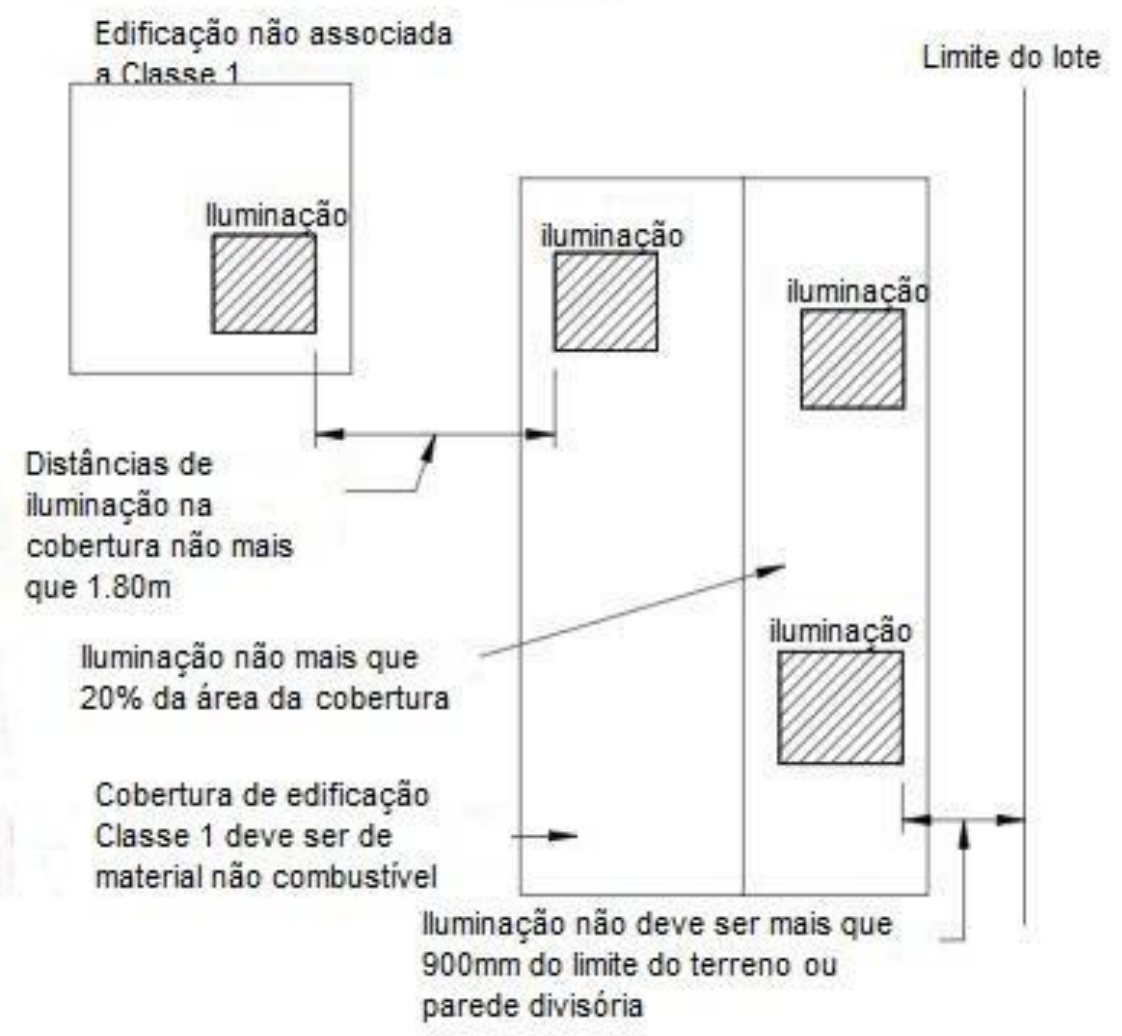

Fonte: ABCB (2018) tradução nossa 


\section{Controle de materiais de acabamento e de revestimento}

De acordo com a ISO 5660.1 ou ISO 9705, os critérios de desempenho de proteção contra incêndio para revestimento de parede e forro seguem a seguinte classificação:

Grupo 1 - material que não alcança o flashover depois de exposto a $300 \mathrm{Kw}$; material que não alcança o flashover quando exposto a $100 \mathrm{~kW}$ por $600 \mathrm{~s}$ e depois de exposto a $300 \mathrm{Kw}$ por $600 \mathrm{~s}$;

Grupo 2 - material que alcança o flashover depois de exposto a $300 \mathrm{Kw}$; material que atinge o flashover após a exposição a $300 \mathrm{KW}$ dentro de 600s após não atingir o flashover quando exposto a $100 \mathrm{KW}$ por $600 \mathrm{~s}$;

Grupo 3 - material que alcança o flashover após 120s de exposição a $100 \mathrm{Kw}$. material que atinge flashover em mais de $120 \mathrm{~s}$, mas dentro de $600 \mathrm{~s}$, quando exposto a $100 \mathrm{kw} \mathrm{e}$;

Grupo 4 - material que atinge flashover dentro de 120s, quando exposto a $100 \mathrm{kw}$.

Há um aumento do nível de segurança exigido para áreas dentro um edifício que fornece condições críticas ou funções essenciais como saídas e áreas públicas. Quando são exigidos o uso de materiais do grupo 1 e 2, o uso da madeira mesmo com aplicação de retardantes de fogo não é permitido nestes locais.

Beirais, varandas e espaços similares que são abertos para o espaço do telhado e são comuns a mais de uma habitação devem ser separados por um revestimento não combustível. Os revestimentos de piso devem se prolongar mais de $150 \mathrm{~mm}$ na parede.

Um sistema de revestimento de parede ou forro, conforme classificado pela AS 5637.1(STANDARD AUSTRALIA, 2015), para edifícios sem sistema de chuveiro automático deve ter:

a) um índice de taxa de crescimento de fumaça não superior a 100; ou

b) uma área de extinção média específica inferior a $250 \mathrm{~m}^{2} / \mathrm{kg}$. 
Uma edificação com um revestimento na parede de alvenaria externa deve ter um espaço de no máximo $50 \mathrm{~mm}$ que separa a parede do revestimento, preenchido com fibra mineral ou outro material resistente ao fogo.

\section{Concessão geral - materiais não combustíveis}

Alguns materiais, apesar de sua combustibilidade, podem ser usados sempre que um material não combustível é exigido no Deemed to Satisfy Provisions. Por exemplo, materiais laminados colados em que cada lâmina, incluindo qualquer núcleo e cada camada adesiva não exceda $1,00 \mathrm{~mm}$ de espessura e a espessura total das camadas adesivas não excede $2,00 \mathrm{~mm}$.

Antes de 2016, o Deemed to Satisfy Provision restringia o uso de materiais combustíveis dentro de partes de um edifício. Este requisito também se aplicava ao CLT. Os edifícios com mais de dois andares e dependendo do seu uso, deveriam ter paredes externas e internas estruturais comum entre unidades resistentes ao fogo e construídas de material não combustível, como concreto ou alvenaria.

Em 2016, os regulamentos foram alterados para permitir o uso de madeira como elemento construtivo. Pode-se, atualmente, utilizar madeira como elemento construtivo desde que esta receba uma proteção ao fogo de material incombustível, que protegerá a madeira da carbonização por um período definido de acordo com os requisitos do sistema para obter um $F R L$ não inferior ao elemento construtivo e que atenda aos requisitos do sistema.

O elemento em madeira deve alcançar uma resistência ao fogo não inferior a FRL 45 minutos quando ensaiado em conformidade com a norma AS 1530.4:2005, ou deve ser protegido com material incombustível para obter a resistência requerida conforme a classificação da edificação e função do elemento.

A madeira com proteção ao fogo pode ser usada para:
a) edifício isolado; ou
b) parede corta-fogo para o pavimento inferior;
c) edifício que não tenha mais de $25 \mathrm{~m}$ de altura;
d) edifício que possua um sistema de chuveiros automáticos. 
Mesmo para edifícios de classe 1, são tomadas medidas preventivas como a instalação de um alarme automático quando há detecção de fumaça além de proteção adicional para aberturas em paredes externas, como janelas com fechamento automático. A operação de fechamento automático deve ser iniciada pela ativação de um detector de fumaça, ou qualquer outro detector considerado adequado de acordo com a norma australiana específica para o sistema. Os detectores de fumaça devem estar localizados em cada lado da parede cortafogo, não mais do que $1,5 \mathrm{~m}$ de distância horizontal da abertura.

Em edifícios classe 2 equipados com um sistema de chuveiro automático, o FRL prescrito pode ser reduzido para 60 mesmo que seja exigido um FRL superior, com exceção para uma parede externa com FRL de 90 exigido, que deve ser mantido.

Embora o projeto de estruturas maciças de madeira seja abordado nas respectivas normas de madeira da Austrália não é feita uma menção específica ao design e detalhamento do CLT. No entanto, os produtos de madeira não especificados no código de obras australiano, ainda podem ser usados se os requisitos avaliados atenderem os critérios das normas.

\subsubsection{Reino Unido}

O The Building Regulation 2010 (Regulamento de Construção de 2010) fornece os requisitos dos regulamentos de construção no país e estão divididas em 16 partes, ("Parte A" a "Parte R"), cobrindo aspectos que asseguram a vida e saúde das pessoas e vida útil dos edifícios.

Para cada parte, existe um "documento aprovado" pelo Secretário de Estado que fornece orientações práticas aos requisitos especificados nos regulamentos de construção 2010 (SI 2010/2214) para o Reino Unido. A parte B refere-se à segurança contra incêndio no Regulamento de Construção do Reino Unido.

Além dos requisitos mínimos exigidos, podem existir formas alternativas de alcançar a conformidade. Assim, não há obrigação de adotar qualquer solução particular contida em um documento aprovado, desde que seja cumprido o requisito do regulamento. O uso de normas britânicas apropriadas e / ou europeias também 
é aceito como uma forma de cumprir os requisitos dos regulamentos de construção (Approved Document B, 2010).

\section{Classificação dos edifícios}

Para todos os edifícios do grupo 1 (residenciais), são exigidos sistemas de detecção de fumaça e alarme de incêndio. Também devem ser providos de saídas de emergência mesmo para edificações térreas. A classificação é feita em relação ao uso e nível de risco e o grupo 1 é subdividido como mostra a Tabela 06.

Tabela 6 - Classificação para os edifícios residenciais no Reino Unido

\begin{tabular}{c|c|c}
\hline Tipo & Grupo & Exemplo \\
\hline \multirow{3}{*}{ Residencial (unifamiliar) } & $1 \mathrm{a}$ & Flat \\
\cline { 2 - 3 } & $1 \mathrm{~b}$ & edificação unifamiliar acima de 4,5m do nível da rua \\
\cline { 2 - 3 } & $1 \mathrm{c}$ & edificação unifamiliar até 4,5m do nível da rua \\
\hline
\end{tabular}

Fonte: Approved Document B (2010) adaptado pela autora

Em edificações com pavimentos até $4,50 \mathrm{~m}$ todos os quartos habitáveis (excluindo cozinhas) devem ter uma janela de emergência (medidas 450x450mm e peitoril máx.1100mm) ou uma porta externa ou acesso direto a uma escada. Fechaduras (com ou sem chave removível) e abridores (com trava de liberação).

\section{Seguranca estrutural}

A edificação deve ser projetada e construída para que em caso incêndio sua estabilidade seja mantida de acordo com os seguintes critérios de resistência ao fogo para os edifícios residenciais da Tabela 7 e 8 :

Tabela 7 - Resistência ao fogo para edificações residenciais

\begin{tabular}{|c|c|c|c|c|}
\hline \multirow{4}{*}{ Grupo } & \multicolumn{4}{|c|}{ Período mínimo de resistência (min.) } \\
\hline & \multicolumn{4}{|c|}{ Térreo ou pavimento superior } \\
\hline & \multicolumn{4}{|c|}{ Altura $(\mathrm{m})$ até topo do andar superior do edifício ou ponto mais alto } \\
\hline & Até $5 \mathrm{~m}$ & Até $18 \mathrm{~m}$ & Até $30 \mathrm{~m}$ & Mais que $30 \mathrm{~m}$ \\
\hline Residencial & \multicolumn{4}{|c|}{-} \\
\hline bloco de apartamento & \multicolumn{4}{|c|}{ - } \\
\hline SA & $30 \mathrm{~min}$. & $60 \mathrm{~min}$. & $90 \mathrm{~min}$. & NP \\
\hline CA & $30 \mathrm{~min}$. & $60 \mathrm{~min}$. & $90 \mathrm{~min}$. & $120 \mathrm{~min}$. \\
\hline edificações unifamiliares & $30 \mathrm{~min}$. & $60 \mathrm{~min}$. & NA & NA \\
\hline
\end{tabular}

Fonte: Approved Document B (2010) adaptado pela autora

Legenda

SA: sem sistema de chuveiros automáticos.

CA: com chuveiros automáticos 
Tabela 8 - Resistência ao fogo dos elementos construtivos

\begin{tabular}{|c|c|c|c|c|c|}
\hline \multirow{2}{*}{$\begin{array}{l}\text { Elemento } \\
\text { estrutural }\end{array}$} & \multirow{2}{*}{\begin{tabular}{|c|} 
Exigência \\
mínima de \\
acordo \\
com a \\
norma \\
europeia \\
(minutos) \\
\end{tabular}} & \multicolumn{3}{|c|}{$\begin{array}{c}\text { Exigência mínima de acordo com a } \\
\text { norma BS } 476 \text { (minutos) }\end{array}$} & \multirow[t]{2}{*}{ Lado exposto } \\
\hline & & $\begin{array}{c}\text { Resistência } \\
\text { Estrutural }\end{array}$ & Estanqueidade & Isolamento & \\
\hline Vigas, pilares & R ver tabela & - & NA & NA & faces expostas \\
\hline Parede estrutural & - & - & NA & NA & ambos os lados \\
\hline \multicolumn{6}{|l|}{ Pisos } \\
\hline $\begin{array}{l}\text { a) piso superior } \\
\text { edificação de } 2 \\
\text { andares com } \\
\text { exceção da } \\
\text { garagem }\end{array}$ & - & $30 \mathrm{~min}$. & $15 \mathrm{~min}$. & $15 \mathrm{~min}$. & parte inferior \\
\hline $\begin{array}{l}\text { b) piso de qualquer } \\
\text { outro pavimento }\end{array}$ & - & - & - & - & parte inferior \\
\hline \multicolumn{6}{|l|}{ Coberturas } \\
\hline $\begin{array}{l}\text { a) qualquer parte } \\
\text { formando uma rota } \\
\text { de fuga }\end{array}$ & REI 30 & $30 \mathrm{~min}$. & $30 \mathrm{~min}$. & $30 \mathrm{~min}$. & parte inferior \\
\hline $\begin{array}{l}\text { b) que exerce } \\
\text { também função de } \\
\text { piso }\end{array}$ & - & - & - & - & parte inferior \\
\hline \multicolumn{6}{|l|}{ Parede externa } \\
\hline $\begin{array}{l}\text { a) até } 1000 \mathrm{~mm} \text { do } \\
\text { limite do lote }\end{array}$ & REI & - & - & - & \begin{tabular}{|l|} 
cada lado \\
separadamente
\end{tabular} \\
\hline $\begin{array}{l}\text { b) mais que } 1000 \\
\mathrm{~mm} \text { do limite do } \\
\text { lote }\end{array}$ & REI 15 & - & - & - & $\begin{array}{l}\text { cada lado } \\
\text { separadamente }\end{array}$ \\
\hline $\begin{array}{l}\text { c) ao lado da rota } \\
\text { de fuga }\end{array}$ & REI 30 & - & - & - & $\begin{array}{l}\text { cada lado } \\
\text { separadamente }\end{array}$ \\
\hline $\begin{array}{l}\text { Paredes de } \\
\text { compartimentação }\end{array}$ & REI 60 & $60 \mathrm{~min}$. & $60 \mathrm{~min}$. & $60 \mathrm{~min}$. & $\begin{array}{l}\text { cada lado } \\
\text { separadamente }\end{array}$ \\
\hline $\begin{array}{l}\text { Shafts no saguão } \\
\text { ou corredor }\end{array}$ & REI 30 & $30 \mathrm{~min}$. & $30 \mathrm{~min}$. & $30 \mathrm{~min}$. & $\begin{array}{l}\text { cada lado } \\
\text { separadamente }\end{array}$ \\
\hline $\begin{array}{l}\text { Parede ou piso } \\
\text { que separa a } \\
\text { garagem anexa a } \\
\text { edificação }\end{array}$ & - & - & - & - & - \\
\hline $\begin{array}{l}\text { Escada } \\
\text { enclausurada }\end{array}$ & REI 30 & $30 \mathrm{~min}$. & $30 \mathrm{~min}$. & $30 \mathrm{~min}$. & $\begin{array}{l}\text { cada lado } \\
\text { separadamente }\end{array}$ \\
\hline \multicolumn{6}{|l|}{ Local protegido } \\
\hline a) saguão & REI 30 & $30 \mathrm{~min}$. & $30 \mathrm{~min}$. & $30 \mathrm{~min}$. & $\begin{array}{l}\text { cada lado } \\
\text { separadamente }\end{array}$ \\
\hline b) corredor & REI 30 & $30 \mathrm{~min}$. & $30 \mathrm{~min}$. & $30 \mathrm{~min}$. & $\begin{array}{l}\text { cada lado } \\
\text { separadamente }\end{array}$ \\
\hline Barreira Cavidade & E30 e E15 & NA & $30 \mathrm{~min}$. & $15 \mathrm{~min}$. & $\begin{array}{l}\text { cada lado } \\
\text { separadamente }\end{array}$ \\
\hline Forro & El 30 & NA & $30 \mathrm{~min}$. & $30 \mathrm{~min}$. & parte inferior \\
\hline Tubulação & E 30 & NA & $30 \mathrm{~min}$. & NE & parte externa \\
\hline
\end{tabular}

Fonte: Approved Document B (2010) adaptado pela autora 


\section{Compartimentação}

As paredes de compartimentação de um pavimento superior devem ser protegidas por uma cobertura e seguir através do ático (Figura 32).

As paredes exteriores do edifício e as coberturas (telhados) devem resistir adequadamente à propagação do fogo entre edifícios levando-se em conta a altura, uso e a localização do edifício no lote.

Figura 32 - Junção da parede de compartimentação com a cobertura

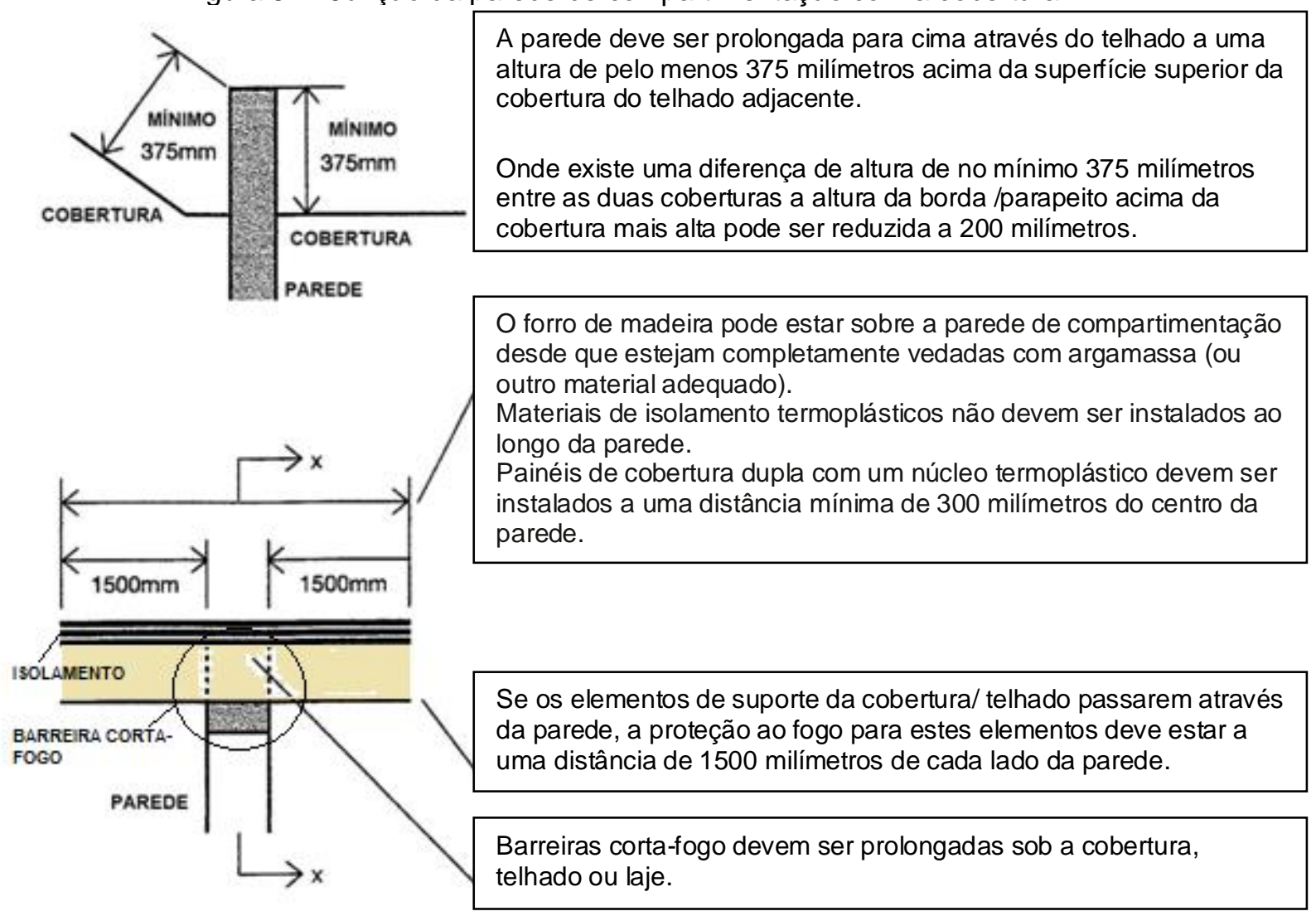

Fonte: Approved Document B (2010) adaptado pela autora

Notas:

1 - Uma barreira corta-fogo deve ser realizada através da espessura total da parede.

2 - Material corta-fogo deve ser estendido para qualquer beiral.

3 - A parede de compartimentação não precisa ser necessariamente construída em alvenaria.

4 - Barreiras corta-fogo devem se prolongar até a parte inferior da cobertura. 
Cada barreira de proteção deve ser instalada de modo a proporcionar, pelo menos 30 minutos de resistência ao fogo e pode ser construída por qualquer material para essa finalidade e deve ser instalada conforme apresenta a Figura 33.

Figura 33 - Disposição das barreiras entre elementos e/ou componentes

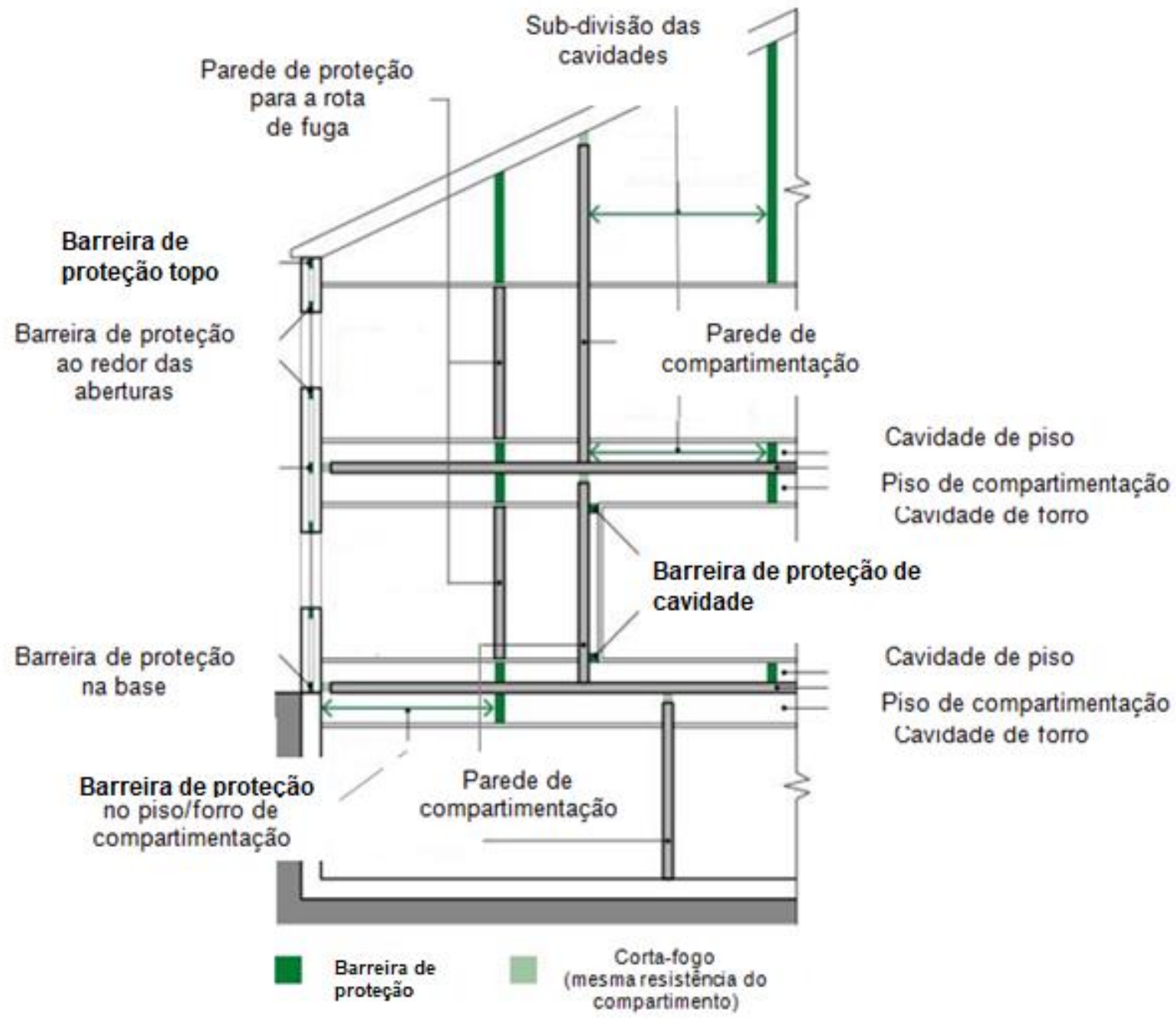

Fonte: Approved Document B (2010) tradução nossa

Notas:

1 - Barreira de proteção: componente ou elemento usado para fechar um espaço vazio (oculto) a penetração ou movimento de fumaça ou fogo.

2 - Barreira corta fogo: selo ou dispositivo usado para vedar os elementos ou componentes e restringir a passagem de fumaça e fogo.

3 - Barreiras de proteção fornecidas em torno das aberturas podem ser formadas pela estrutura da janela ou porta, se a estrutura for de aço ou de madeira. 
No entanto, as barreiras de proteção em uma parede de compartimentação ou instalada em torno das aberturas podem ser de:

a) aço, com pelo menos $0,5 \mathrm{~mm}$ de espessura;

b) madeira, com pelo menos 38 milímetros de espessura; ou

c) lã mineral polietileno, ou de placas de lã mineral, em ambos os casos sob compressão, quando instalado na cavidade; ou

d) placas de silicato de cálcio, à base de cimento ou gesso com, pelo menos, $12 \mathrm{~mm}$ de espessura.

\section{$\underline{\text { Selagem da tubulação }}$}

Tubulações que passam através de elementos de compartimentação devem ser seladas, protegidas (luvas) e ter um diâmetro limitado.

Uma tubulação de chumbo, alumínio, liga de alumínio, de fibrocimento ou PVC, com um diâmetro interno nominal de 160 milímetros no máximo, pode ser utilizada com um acabamento não combustível, como mostrado na Figura 34.

Figura 34 - Proteção contra fogo em tubulações
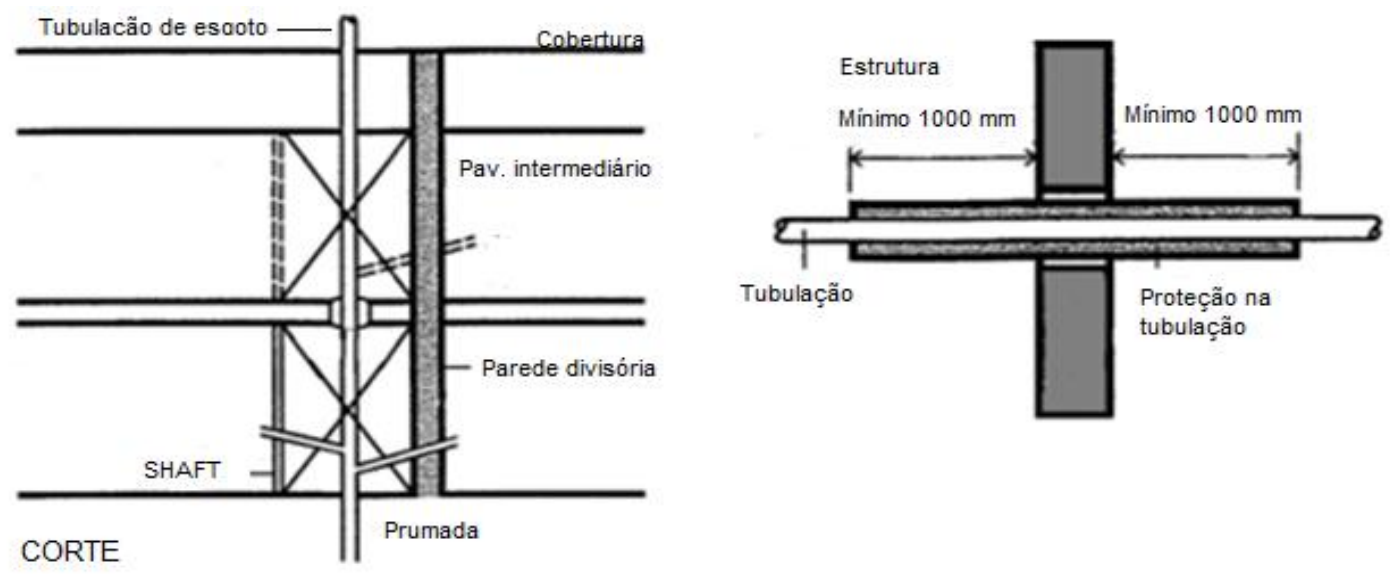

Fonte: Approved Document B (2010) tradução nossa

Materiais como gesso, argamassas etc. podem ser utilizados como selo corta-fogo, no entanto nem todos eles serão adequados em cada situação. O código britânico recomenda buscar orientação para o projeto, instalação e manutenção de proteção passiva contra o fogo na Association for Specialist Fire Protection (ASFP). 
Se uma parede externa tem a resistência ao fogo apropriada, mas possui material combustível com mais de $1,00 \mathrm{~mm}$ de espessura como revestimento externo, a parede é contada como uma área não protegida (Figura 35).

Figura 35 - Cálculo da área para paredes com revestimento combustível

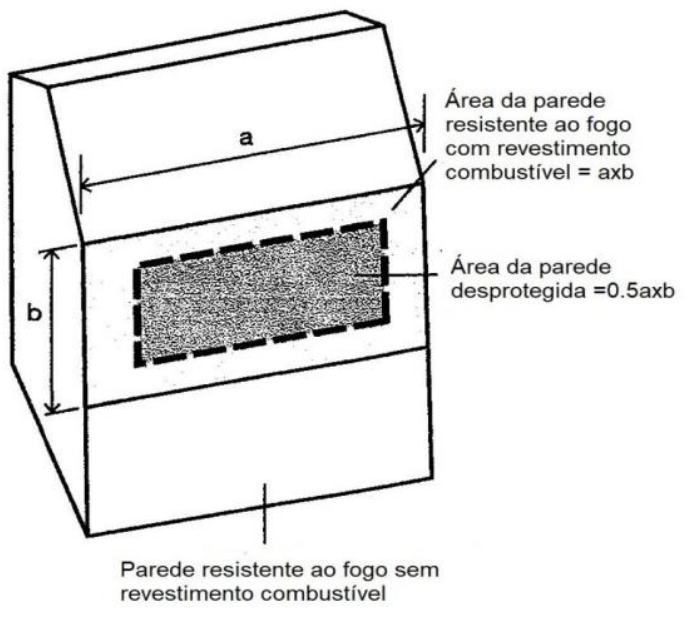

Fonte: Approved Document B (2010) tradução nossa

Figura 36 - Áreas não protegidas que podem ser desconsideradas para o cálculo da distância de separação a partir do limite

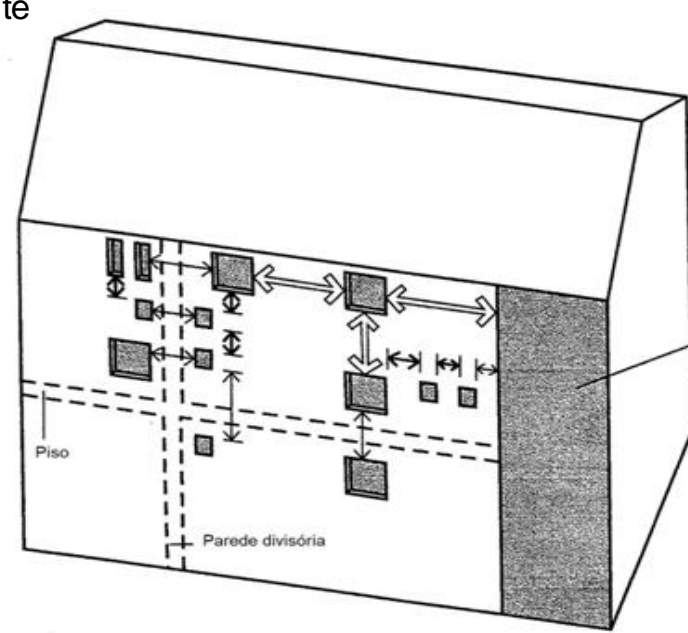

Área não protegida da parede externa de uma escada com proteção ao fogo interna pode ser ignorada para efeito de separação à distância

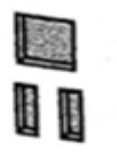

Áreas desprotegidas até $1 \mathrm{~m} 2$ que podem ser a soma de uma ou duas áreas menores de $1000 \times 1000 \mathrm{~mm}$

Q Área maior que $0,1 \mathrm{~m} 2$

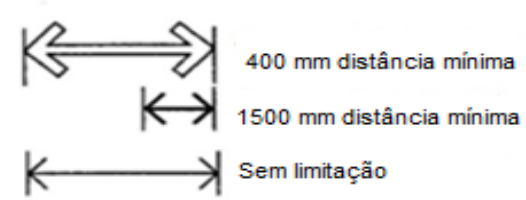

$K$ Sem limitação

Nota: para o efeito desta disposição, um material com uma classificação de classe 0 - classe Nacional - ou classe B-s3, classificação d2 - classe Europeia - não precisam ser contadas como área desprotegida 
No caso de um beiral fixo ao lado de um edifício, com pelo menos $2,00 \mathrm{~m}$ a partir do limite do lote, a distância de separação pode ser determinada a partir da parede, em vez da borda do beiral (Figuras 37 e 38).

Figura 37 - Distância das estruturas de proteção de aberturas

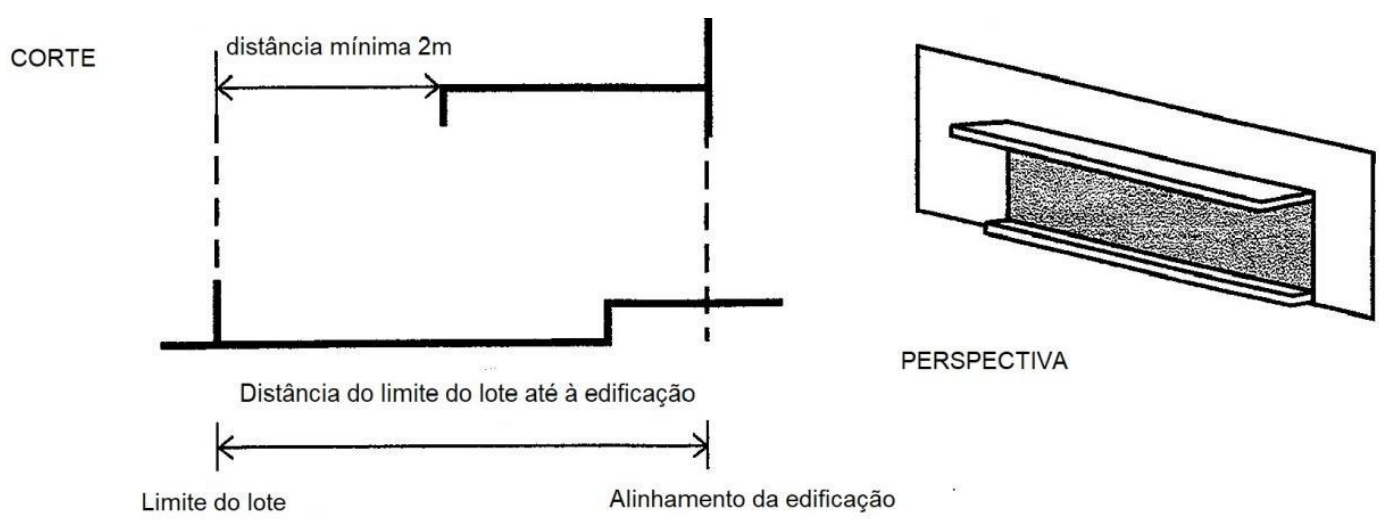

Fonte: Approved Document B (2010) tradução nossa

Figura 38 - Áreas desprotegidas permitidas para edificações até $24 \mathrm{~m}$ de altura

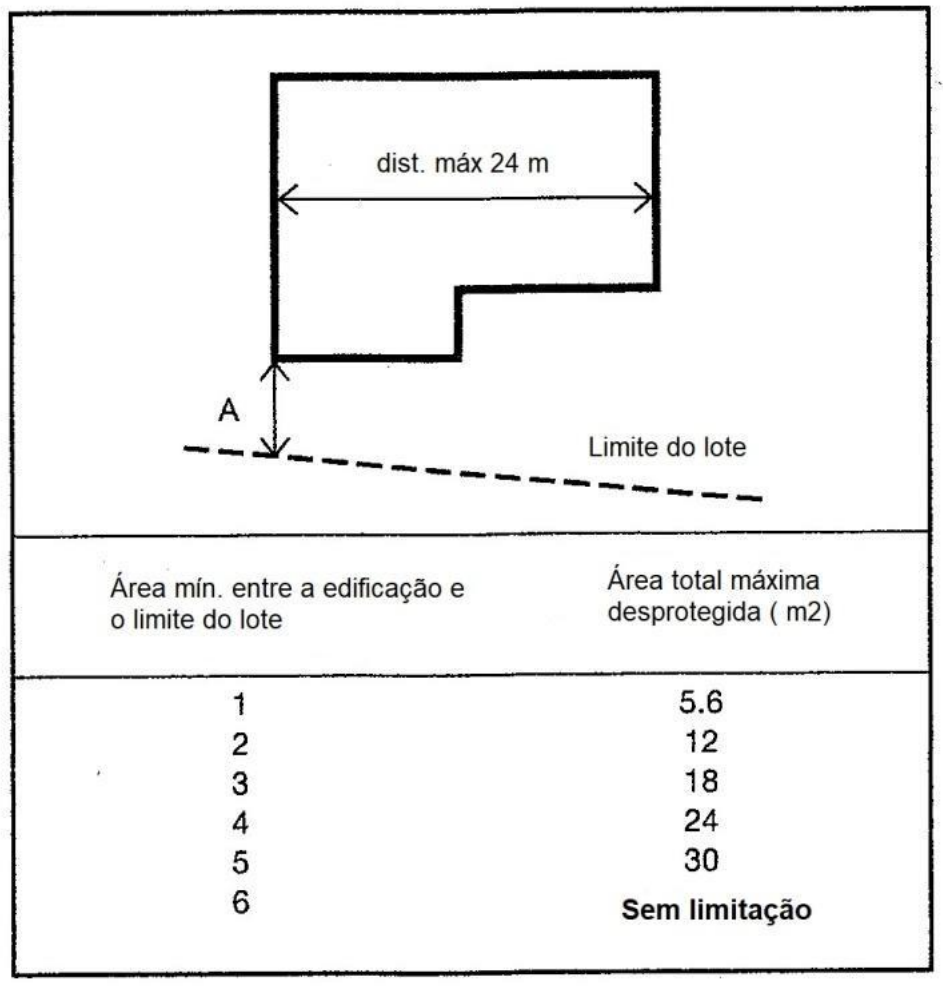

Fonte: Approved Document B (2010) tradução nossa 
Para reduzir o risco de propagação do fogo entre aberturas de iluminação natural (clarabóias constituídas de material plástico) nas coberturas, estas devem manter distância mínima de 3,00 m e ter área máxima de 5,00 m².

\section{Distâncias entre edificações}

Quando a parede está a 1,00 m ou mais a partir do limite do lote, um padrão reduzido de resistência ao fogo é aceito na maioria dos casos e a parede só precisa ter resistência ao fogo do lado interno da edificação.

Disposições também são feitas para restringir a combustibilidade das paredes externas de edifícios que estão a menos de 1,00 $\mathrm{m}$ do limite do lote. As Figuras 39 a 41 mostram quando a parede da edificação deve ter resistência ao fogo em relação às divisas do lote entre outros.

As distâncias para outros edifícios no mesmo lote também precisam ser consideradas. Esta distância assumida é chamada limite teórico (Figura 40).

Figura 39 - Limites do lote

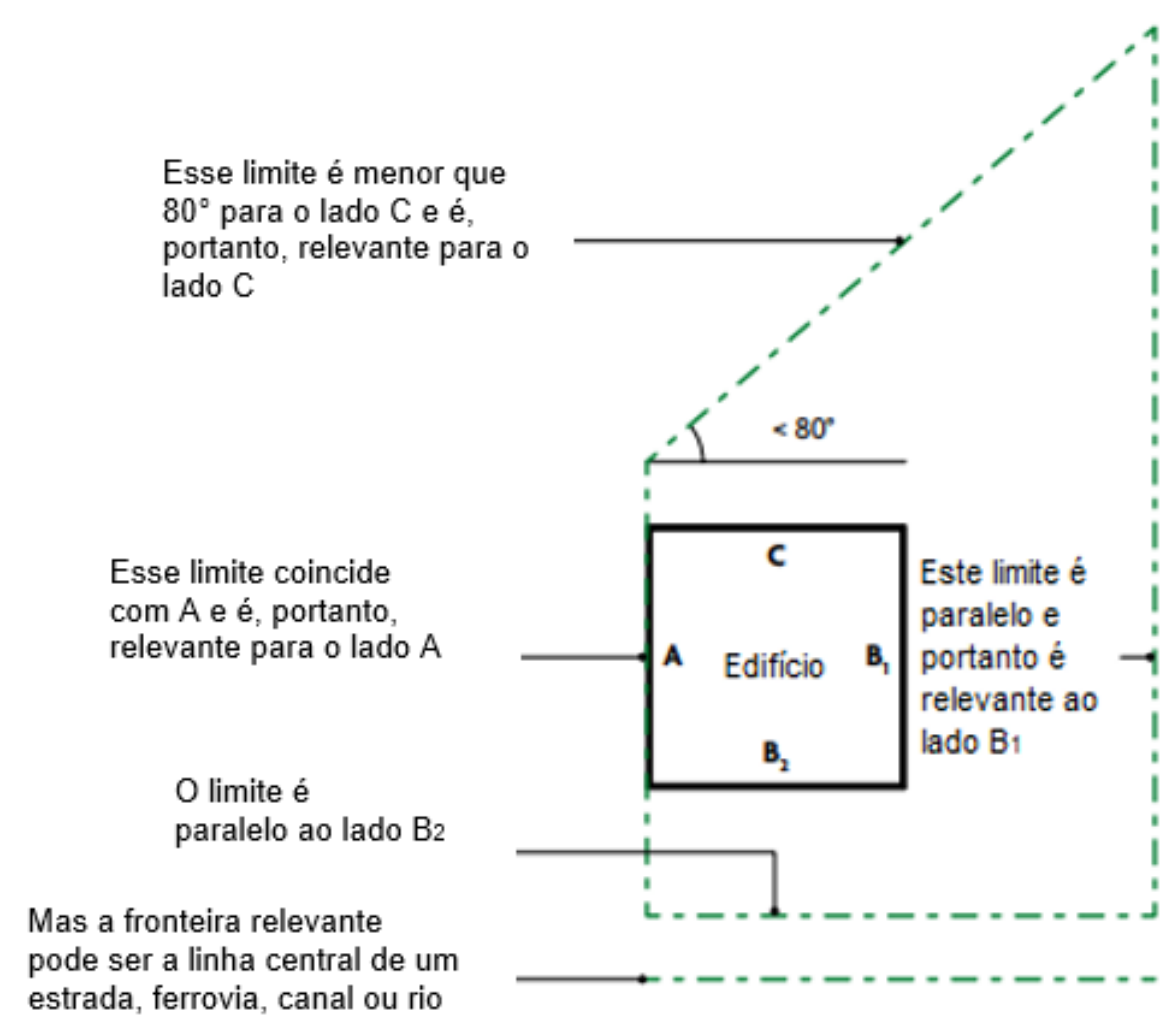

Fonte: Approved Document B (2010) tradução nossa 
Figura 40 - Limite teórico

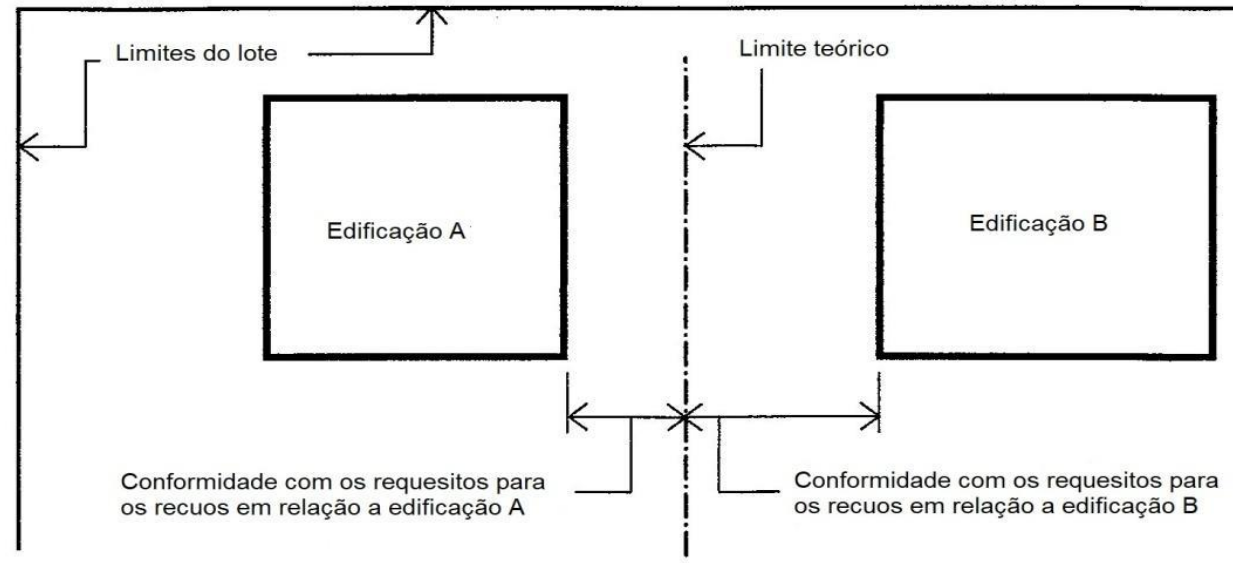

Fonte: Approved Document B (2010) tradução nossa

Figura 41 - Requisitos para paredes e superfícies externas

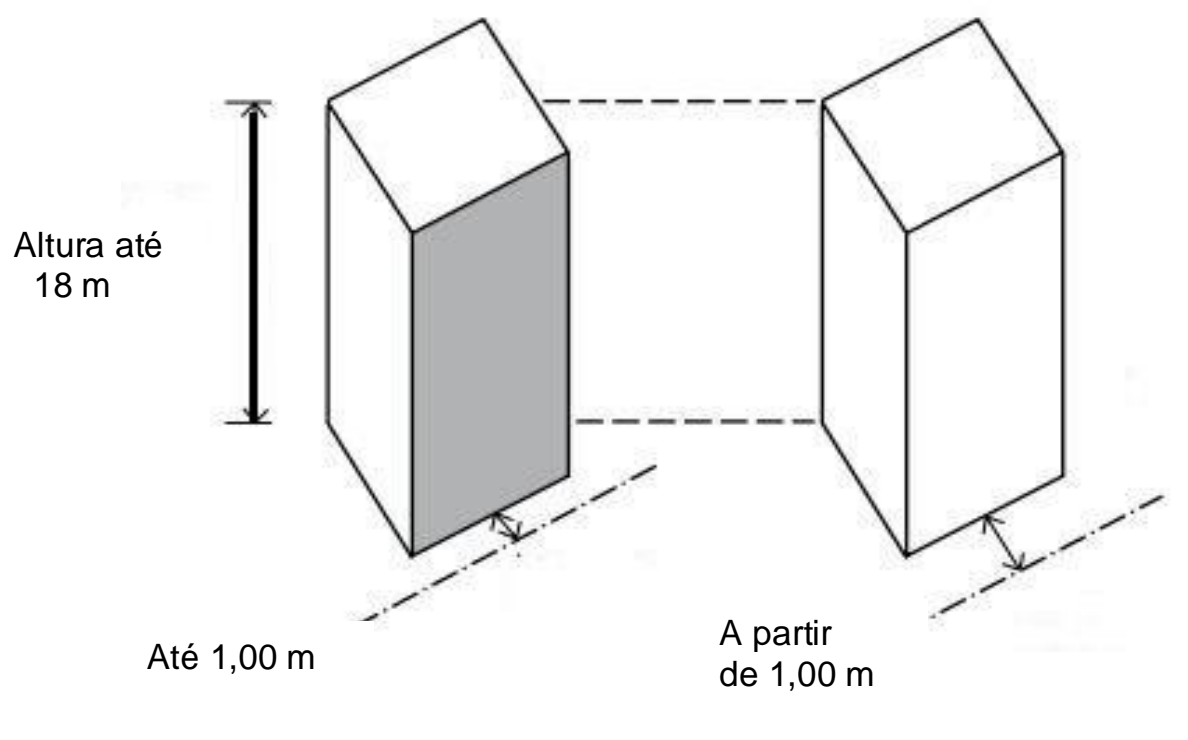

Fonte: Approved Document B (2010) tradução nossa

\section{-._-_. Limite relevante}

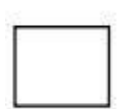

Sem classificação

Class 0 (national class) ou B-s3, d2 ou outra que se aplique (European class)

Revestimento como alumínio até $0,5 \mathrm{~mm}$ de espessura ou outro material até $0,2 \mathrm{~mm}$.

Nota: Class 0 ou B-s3, d2 - Qualquer material que atenda aos dois critérios a seguir:

a. Classe 1, de acordo com BS 476-7.

b. Possui um índice de propagação de incêndio (I) de no máximo 12 e subíndice (i1) de máximo de 6 , determinado usando o método indicado na BS 476-6. Índice de desempenho (I) refere-se ao desempenho geral do teste, enquanto o subíndice (i1) é derivado dos três primeiros minutos do teste 
Controle de materiais de acabamento e de revestimento

Revestimentos internos devem resistir adequadamente à propagação das chamas e a taxa de liberação de calor ou a taxa de crescimento de incêndio deve atender sua classificação nacional ou a classificação europeia.

Por exemplo, em relação aos materiais combustíveis, como a madeira, para se ter o controle de propagação do fogo no interior da edificação, a taxa de liberação de calor e a taxa de crescimento do fogo devem atender à classificação conforme os ensaios BS 476-6:1989 e BS 476-7:1997, respectivamente.

No Reino Unido, a norma específica para o CLT é a BS EN 16351:2015 Timber structures - Cross laminated timber - Requirements, na norma há requisitos e critérios que devem ser atendidos de reação e resistência ao fogo, conforme segue na Tabela 9:

Vale ressaltar que após o incêndio do edifício residencial Grenfel Tower foram feitas alterações no código construtivo de segurança contra incêndio. Em 21 de dezembro de 2018, entrou em vigor uma emenda ao regulamento vigente que proíbe o uso de materiais combustíveis nos sistemas de paredes externas de edifícios residenciais acima de 67 andares, exceto em esquadrias, portas e esquadrias de portas.

Especificamente, isso excluiria o CLT nas paredes externas de qualquer edifício residencial acima de 6/7 andares. Porém a legislação não proíbe o CLT, pois o uso de madeira para lajes, paredes internas, núcleos ou qualquer outro uso interno ainda é permitido.

Tabela 9 - Resumo dos requisitos BS EN 16351:2015 - Timber structures - Cross laminated timber - Requirements

\begin{tabular}{|c|c|c|c|c|}
\hline$\frac{\circ}{\circ}$ & $\begin{array}{c}\text { Característica } \\
\text { avaliada }\end{array}$ & $\begin{array}{c}\text { Requisito } \\
\text { (CLT com ou sem } \\
\text { finger joints } \\
\text { espacados) }\end{array}$ & $\begin{array}{l}\text { Método de } \\
\text { avaliação }\end{array}$ & Critério \\
\hline 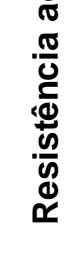 & Geometria & $\begin{array}{l}\text { - A espessura total da } \\
\text { madeira laminada } \\
\text { cruzada } \\
\text { - A espessura final de } \\
\text { qualquer camada } \\
\text { - Dimensão dos frisos }\end{array}$ & & $\begin{array}{l}\text { - A espessura total do CLT } \\
\text { não deve exceder } 500 \mathrm{~mm} \\
\text { - A espessura final de } \\
\text { qualquer camada será } \geq \text { a } 6 \\
\text { mm e a largura } \leq \text { a } 45 \mathrm{~mm} \\
\text { - Frisos podem ter uma } \\
\text { profundidade máxima de } 90 \%\end{array}$ \\
\hline
\end{tabular}




\begin{tabular}{|c|c|c|c|c|}
\hline & & $\begin{array}{l}\text {-Desvios aceitáveis } \\
\text { máximos } \\
\text { - Tamanhos corrigidos } \\
\text { e fator de deformação } \\
\text { de umidade } \\
\text { - Lamelas (incluindo } \\
\text { orientação de camada) }\end{array}$ & & $\begin{array}{l}\text { da espessura da laminação e } \\
\text { uma largura máxima de } 4 \mathrm{~mm} \\
\text { - A espessura corrigida da } \\
\text { seção transversal não deve } \\
\text { desviar-se da espessura } \\
\text { nominal por mais de } \pm 2 \mathrm{~mm} \\
\text { ou } 2 \% \text { da espessura nominal } \\
\text { qualquer é maior. } \\
\text { - A espessura corrigida das } \\
\text { camadas individuais não deve } \\
\text { desviar-se da espessura } \\
\text { nominal em mais de } \pm 1 \text { mm } \\
\text { - Se o teor de umidade real } \\
\text { difere do teor de umidade de } \\
\text { referência, deve ser corrigido } \\
\text { - Cada camada deve incluir } \\
\text { pelo menos três lamelas, pelo } \\
\text { menos duas delas feitas de } \\
\text { laminações de madeira } \\
\text {-Camadas feitas de } \\
\text { laminações ou painéis de } \\
\text { madeira maciça devem ser } \\
\text { dispostas ortogonalmente } \\
\text { - A soma das espessuras de } \\
\text { todas as camadas de madeira } \\
\text { com base painel de CLT pode } \\
\text { ser de até } 50 \% \text { da espessura } \\
\text { total. }\end{array}$ \\
\hline & $\begin{array}{l}\text { Densidade } \\
\text { da madeira }\end{array}$ & Rigidez & $\begin{array}{l}\text { EN14081- } \\
1: 2005 \\
\text { (avaliar, } \\
\text { verificar ou } \\
\text { ensaio) }\end{array}$ & $\begin{array}{l}\text { De acordo com os critérios EN } \\
14081-1: 2005+1: 2011,6.2 \\
\text { Classificação de acordo com } \\
\text { EN } 338\end{array}$ \\
\hline & $\begin{array}{l}\text { Densidade dos } \\
\text { painéis }\end{array}$ & $\begin{array}{l}\text { Classe de serviço } 2 \text { ou } \\
3 \text { de acordo com a EN } \\
1995-1-1\end{array}$ & Verificar & EN 13986 \\
\hline & Espécies & $\begin{array}{l}\text { Determinar a espécie } \\
\text { de acordo EN } 1912 .\end{array}$ & Verificar & $\begin{array}{l}\text { Nem todas as espécies } \\
\text { listadas acima têm um grau } \\
\text { nacional relacionado a uma } \\
\text { classe de força europeia em } \\
\text { EN } 1912\end{array}$ \\
\hline \multirow{3}{*}{ 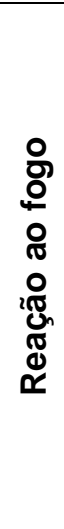 } & Lamelas & $\begin{array}{l}\text { Desempenho das } \\
\text { lamelas ou do } \\
\text { conjunto das lamelas } \\
\text { que formam o painel } \\
\end{array}$ & EN 14081-1 & EN 14081-1 \\
\hline & Painel & $\begin{array}{l}\text { Conjunto das lamelas } \\
\text { que formam o painel }\end{array}$ & EN 13986 & $\begin{array}{l}\text { EN } 13986 \text { (madeira } \\
\text { compensada, LVL, painéis } \\
\text { sólidos) }\end{array}$ \\
\hline & Painel & $\begin{array}{l}\text { Desempenho dos } \\
\text { painéis em posição } \\
\text { perpendicular entre si. } \\
\text { Para testes de acordo } \\
\text { com o EN } 13823 \text { (teste } \\
\text { SBI). }\end{array}$ & $\begin{array}{l}\text { ou ensaiado } \\
\text { de acordo } \\
\text { com o } \\
\text { método } \\
\text { EN 13501-1 }\end{array}$ & $\begin{array}{l}\text { Classes de acordo com EN } \\
13501-1\end{array}$ \\
\hline
\end{tabular}

Fonte: da autora (2019) 
Entretanto, há várias soluções que podem ser adotadas sem comprometer a estrutura do sistema de CLT. Pesquisas iniciais de edifícios construídos com CLT demonstraram que a substituição das paredes externas de CLT por um painel de metal, satisfaria a proibição e teria pouco impacto sobre o projeto. No entanto essa alteração não afeta os sistemas de estrutura de madeira para edifícios baixos (APPROVED DOCUMENT B - vols. 1 \& 2 Amendments, 2018).

\subsubsection{Estados Unidos da América}

Nos Estados Unidos da América (E.U.A), cada jurisdição (estado, município ou cidade) tem seu próprio código de construção. Porém o Internacional Code Council (ICC) tem um código modelo - o International Building Code (IBC) - que não tem limitações regionais. A maioria dos estados que adotam esse modelo segue um ciclo de três anos para manter-se atualizado com o processo de revisão do ICC.

Além do IBC, a Associação Nacional de Proteção contra Incêndios (National Fire Protection Association - NFPA) é uma das principais organizações que fornece informações e conhecimento através da publicação de mais de 300 códigos e normas de consenso, além de incentivos de pesquisa, treinamento, educação, divulgação e defesa de direitos voltados para a área de segurança contra incêndio.

\section{Classificação das edificações}

A classificação $R$ é designada para uso residencial conforme a seguinte Tabela 1 e dividido em quatro subgrupos:

- R1 - hotel, motel, pensão

- R2 - sobrados e dormitórios de aluguel

- $\mathrm{R} 3$ - residências unifamiliares

- R4 - cuidados especiais

Além da divisão por uso e ocupação o IBC também tem classes de construção baseados nos tipos de materiais e exigências para a resistência ao fogo, determinando assim a proteção necessária para cada grupo.

$\underline{\text { Tipos de construção }}$ 
As edificações são classificadas em cinco tipos básicos, de acordo com o tipo de sua construção designada como Tipo I, Tipo II, Tipo III, Tipo IV e Tipo V.

As edificações com sistemas construtivos de madeira são comumente classificadas no Tipo III, IV, V. A altura e a área máxima de uma estrutura dependem da classificação de ocupação e da presença de um sistema de chuveiros automáticos. As alturas dos edifícios do Grupo R com base nestas classificações de construção não devem exceder as alturas especificadas na Tabela 10.

\begin{tabular}{|c|c|c|c|c|c|c|c|}
\hline \multirow{5}{*}{ Alturas (m) } & \multirow{2}{*}{ Classificação de uso } & \multirow{2}{*}{ - } & \multicolumn{2}{|c|}{ Tipo III } & \multirow{2}{*}{ Tipo IV } & \multicolumn{2}{|c|}{ Tipo V } \\
\hline & & & A & $B$ & & A & $B$ \\
\hline & \multirow{3}{*}{$\mathrm{R}$} & SA & 19,81 & 16,76 & 19,81 & 15,24 & 12,19 \\
\hline & & A 13R & 18,28 & 18,28 & 18,28 & 18,28 & 18,28 \\
\hline & & A & 25,9 & 22,86 & 25,9 & 21,33 & 18,28 \\
\hline
\end{tabular}

Fonte: IBC (2018)

Legenda

SA: sem sistema de chuveiros automáticos.

A 13R: com chuveiros automáticos residenciais (NFPA 13R System)

A: com chuveiros automáticos (NFPA 13 System)

Sistemas de chuveiros automáticos em ocupações do Grupo $\mathrm{R}$ com até quatro andares de altura em prédios que não excedam 60 pés $(18288 \mathrm{~mm})$ de altura acima do plano de inclinação devem ser instalados em todos ambientes, de acordo com a NFPA 13R.

A área de construção máxima permitida para edifícios residenciais fornecidos com um sistema de chuveiros automáticos compatível com NFPA 13R é determinada multiplicando-se a área construída por pavimento pelo número de andares. Aumentos adicionais podem ser concedidos dependendo da localização do edifício no lote.

\section{$\underline{\text { Segurança estrutural }}$}

As unidades de habitação geminadas devem ser separadas uma das outras por elementos construídos com barreiras corta-fogo, com uma resistência não 
inferior a 60 min. Quando há um sistema de chuveiros automáticos, a exigência de resistência ao fogo diminui para $30 \mathrm{~min}$.

A classificação de resistência ao fogo de elementos estruturais e de conjuntos de edifícios deve ser determinada de acordo com os requisitos prescritivos baseados nos procedimentos de ensaios estabelecidos na ASTM E119:2019 - Standard test methods for fire tests of building construction and materials ou UL 263: 2011 - Standard for Fire Tests of Building Construction and Materials, ou outros métodos de teste aprovados ou métodos analíticos.

Os materiais usados para a construção da edificação devem ter resistência ao fogo - elementos e conjuntos, como pisos, lajes, paredes e coberturas classificados conforme Tabela 11.

Tabela 11 - Classificação de resistência ao fogo para materiais de construção

\begin{tabular}{|c|c|c|c|c|c|}
\hline \multirow{2}{*}{ Elementos construtivos } & \multicolumn{2}{|l|}{ Tipo III } & \multirow{2}{*}{$\begin{array}{c}\text { Tipo IV } \\
\text { HT }\end{array}$} & \multicolumn{2}{|c|}{ Tipo V } \\
\hline & A & B & & A & $B$ \\
\hline Estrutura principal do telhado & 1 & 0 & $\mathrm{HT}$ & 1 & 0 \\
\hline Paredes estruturais & & & & & \\
\hline Externa & 2 & 2 & 2 & 1 & 0 \\
\hline Interna & 1 & 0 & $1 / \mathrm{HT}$ & 1 & 0 \\
\hline Paredes não estruturais externas ${ }^{12}$ & Ver tabela & & & & \\
\hline Paredes não estruturais internas & 0 & 0 & $1^{3}$ & 0 & 0 \\
\hline Elementos e componentes do piso & 1 & 0 & HT & 1 & 0 \\
\hline Elementos e componentes do telhado & $1^{3}$ & 0 & HT & $1^{4}$ & 0 \\
\hline
\end{tabular}

Fonte: IBC (2018)

Legenda:

A - Material combustível

B - Material não combustível

Notas:

1. Não menor que a classificação de resistência ao fogo exigida pelas distâncias seguras.

2. Não menor que a classificação de resistência ao fogo conforme a tabela.

3. As paredes divisórias interiores devem ser feitas de madeira maciça por pelo menos duas camadas de tábuas de $25 \mathrm{~mm}$ ou de $102 \mathrm{~mm}$ de espessura.

4. Em todas as ocupações de madeira pesada será permitida a resistência ao fogo de uma hora ou menos. 


\section{Compartimentação}

As paredes resistentes ao fogo devem ser de materiais incombustíveis ou de combustão limitada. A largura total de todas as aberturas nas paredes resistentes ao fogo não deve exceder $25 \%$ do comprimento da parede em cada andar.

Os elementos construtivos classificados como resistentes ao fogo - pisos ou telhados ou uma combinação de pisos ou cobertura - devem ter resistência conforme estabelecido na Tabela 11. Nos casos em que o forro constitua uma membrana protetora para resistência ao fogo - elementos de piso / laje ou cobertura / laje, a construção e os elementos estruturais horizontais de suporte não precisam ser individualmente protegidos contra incêndio, a menos que tal seja exigido.

As lajes devem formar um elemento contínuo resistente ao fogo e a passagem das tubulações deve ser protegida contra a propagação de chamas e dos produtos da combustão, como exemplo um amortecedor de radiação instalado no alinhamento da laje e a área total das aberturas não deve ser maior do que 100 pés = $\left(64,52 \mathrm{~mm}^{2}\right)$.

Clarabóias desprotegidas não devem ser permitidas em construções de telhados que requeiram resistência ao fogo.

As paredes externas classificadas com resistência ao fogo devem ser contínuas desde a fundação até não menos de 30 polegadas $(760 \mathrm{~mm})$ acima do telhado, exceto quando não é exigido.

As janelas com classificação de resistência de $45 \mathrm{~min}$, em paredes externas, não deverão ter uma área superior a 84 pés $2(7,8 \mathrm{~m}$ 2), e largura ou altura superiores a 12 pés $(3660 \mathrm{~mm})$.

\section{Separação entre edificações}

As distâncias seguras para as residências são estabelecidas de acordo com a Tabela 12: 
Tabela 12 - Distância das edificações do Grupo R

\begin{tabular}{c|c|c}
\hline Distâncias seguras (m) & Tipos de construção & Grupo $\mathbf{R}^{\mathbf{1}}$ \\
\hline $\mathrm{x}<1,5$ & Todos & 1 \\
\hline $1,5 \leq \mathrm{x}<3,0$ & I A & 1 \\
\hline $3,0 \leq \mathrm{x}<9,0$ & outros & 1 \\
\hline & IA, IB & 1 \\
\hline & II B VB & 0 \\
\hline $\mathrm{x} \geq 9,0$ & outros & 1 \\
\hline & Todos & 0 \\
\hline
\end{tabular}

Fonte: IBC (2018)

Nota:

1 - Para uma edificação do Grupo R-3 Tipo IIB e VB, a parede externa não precisa ter uma classificação de resistência ao fogo onde a distância segura for de $1,50 \mathrm{~m}$ ou mais.

Controle de materiais de acabamento e de revestimento

Os materiais de revestimento de paredes internas e forros devem ser ensaiados e classificados de acordo com ASTM E84:2019 - Standard Test Method for Surface Burning Characteristics of Building Materials, ou ANSI / UL 723:2018 Standard for Test for Surface Burning Characteristics of Building Materials.

Em construções novas, a estrutura do conjunto de piso devem ser providos de uma membrana contínua de placas de gesso com espessura nominal não inferior a $1 / 2$ pol. (13 mm), ou equivalente, para proteger os membros da estrutura do piso de uma exposição ao fogo por baixo, com algumas exceções conforme especificadas no código.

Quando a edificação estiver protegida por um sistema de chuveiros automáticos, não será exigida uma proteção da parte inferior do piso com placas de gesso.

O revestimento da laje (teto) deve ser constituído por materiais incombustíveis e deve se estender por uma medida não inferior a 48 pol. (1220 mm) de cada lado da parede. $O$ código norte-americano permite o uso de madeira tratada com retardante de fogo, para alcançar o requisito exigido. 
O IBC 2015 foi a primeira edição do código a reconhecer novos produtos de madeira maciça, como o CLT e outros produtos de madeira engenheirada, pois a madeira maciça permite maiores áreas e alturas.

O sistema construtivo de CLT se aplica à construção do tipo IV (Heavy Timber, HT). As recomendações para os edifícios classificados no tipo IV determinam que as paredes externas sejam construídas com materiais não combustíveis, madeira tratada com retardante de fogo e protegida ou madeira laminada cruzada (CLT) com espessura não inferior a $152 \mathrm{~mm}$.

Elementos de construção interiores devem ser de madeira maciça ou laminada, sem espaços vazios. As colunas que suportam as cargas da laje devem ter uma dimensão nominal mínima de 152,4 mm x 203,2 mm e 203,2 mm x 203,2 $\mathrm{mm}$, se suportarem as cargas de piso. As vigas do piso devem ter uma dimensão nominal mínima de 152,4mm x 254 mm, e vigas da laje devem ter espessura mínima de $101,6 \mathrm{~mm} \times 152,4 \mathrm{~mm}$.

O piso deve ter uma espessura mínima de 76,2 $\mathrm{mm}$ e com revestimento com encaixe tipo macho e fêmea e dimensão de $25,4 \mathrm{~mm}$ ou madeira laminada cruzada (CLT) de 101,6 mm de espessura. Os forros dos telhados devem ter uma espessura mínima de $50,8 \mathrm{~mm}$ ou CLT de 76,2 mm.

As paredes de compartimentação devem apresentar resistência ao fogo de $60 \mathrm{~min}$. ou pelo menos serem revestidas com duas camadas de placas de gesso acartonado de espessura mínima de 25,4 mm ou material laminado de 101,6 mm.

Nos Estados Unidos da América (E.U.A) a norma técnica relativa ao controle de qualidade para o CLT é a ANSI/APA PRG 320-2012 Standard for PerformanceRated Cross-Laminated Timber cujo objetivo é o controle da qualidade da produção e classificação dos componentes e elementos para o sistema. Em relação à exposição ao fogo a norma dá orientações para a avaliação do desempenho do adesivo usado em temperatura elevada. 


\subsubsection{Brasil}

No Brasil, até o início de 1970, a regulamentação sobre a segurança contra incêndio era quase inexistente, apenas sendo citada em Códigos de Obras municipais referente ao dimensionamento das larguras de saídas de emergência e escadas e a estrutura de prédios altos. A regulamentação do Corpo de Bombeiros indicava apenas a exigência de hidrantes e extintores como medidas de combate a incêndio (SEITO, 2008).

Foi a partir de grandes incêndios em edificações e infelizmente com a perda de muitas vidas, é que se voltou a atenção para a questão da segurança contra incêndio no país. Após o incêndio da indústria da Volkswagen em dezembro de 1970, iniciaram-se os estudos para a implantação de sistemas de controle de fumaça, que começaram a ser realmente exigidos no Brasil a partir de 2001, na regulamentação do Corpo de Bombeiros de São Paulo.

Somente após grandes tragédias, como ocorreram em São Paulo no edifício Andraus,1972 e no edifício Joelma,1974, foi que a Prefeitura de São Paulo edita o Decreto Municipal no 10.878 que estabeleceu normas para a segurança dos edifícios a serem observadas durante a fase de projeto, a execução e instalação de equipamentos. Logo após, as regras estabelecidas nesta regulamentação são incorporadas na Lei municipal n 8266 de 1975, o novo Código de Edificações para o Município de São Paulo. Além da mudança na regulamentação municipal, no meio técnico houve a edição da NB 208/74 da ABNT, "Saídas de Emergência em Edifícios Altos", que posteriormente se transformou na ABNT: NBR 9077:2001 (SEITO, 2008).

\subsubsection{Código de obras}

Ainda hoje no Brasil, não existe um código nacional de proteção contra incêndio. A regulamentação é estabelecida por meio de códigos de obras municipais e legislações estaduais, federais e por normas técnicas brasileiras como aqueles elaborados pela ABNT. Atualmente, as Regulamentações Estaduais dos Corpos de Bombeiros, complementadas pelas instruções técnicas em cada estado cumprem o 
papel, regulamentando requisitos e critérios para a segurança contra o incêndio no país de forma extensiva.

\subsubsection{Decreto Estadual de São Paulo}

Em São Paulo, o decreto estadual № 46.076 de 2001, evoluiu tecnicamente para um novo modelo de regulamentação e passou a ser reproduzido em outros estados brasileiros. Esse foi um grande avanço, complementado, mais recentemente, com a aprovação do Código Estadual de Proteção Contra Incêndios e Emergências (Lei Complementar № 1.257, 06 de janeiro de 2015, regulamentado pelo Decreto № 63.911 de 10 de dezembro de 2018).

Figura - 42 Incêndios por tipo de ocupação

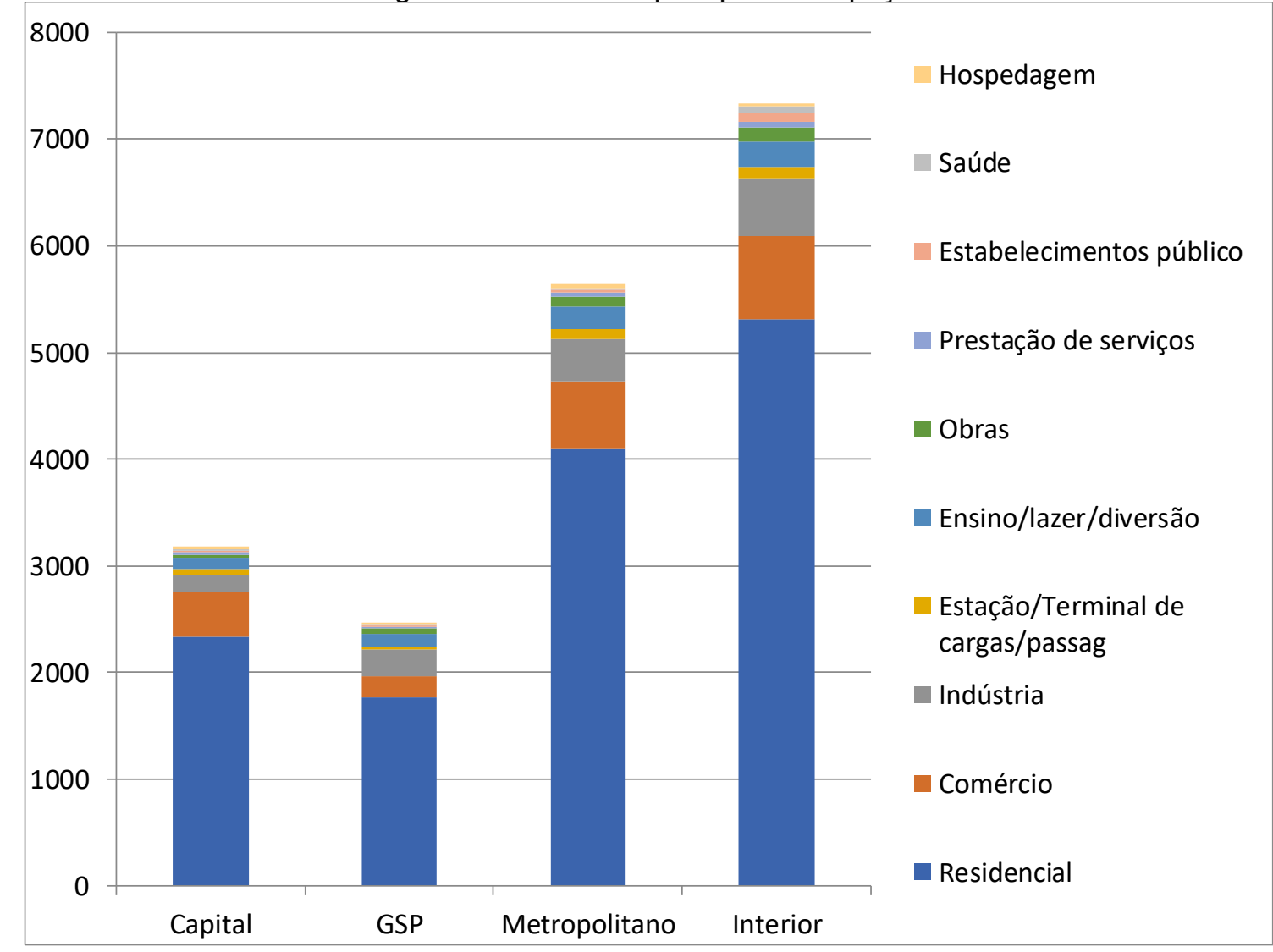

Fonte: Corpo de Bombeiros da Polícia Militar do Estado de São Paulo, Anuário dos Serviços de Bombeiros (2015).

Assim, a regulamentação em vigor é o Decreto № 63.911 de 10 de dezembro de 2018. Mesmo nesta atual regulamentação não há o equacionamento, em especial para a cidade de São Paulo, do abastecimento de água para incêndio, por meio de hidrantes públicos, conforme discutido por alguns autores (SEITO, 2018). 
Também não há exigências mínimas de segurança para as edificações de uso residencial exclusivamente unifamiliares até dois pavimentos com área inferior a $750 \mathrm{~m}^{2}$ classificação A-1 conforme o regulamento vigente. No entanto, incêndios mais frequentes, tanto pequenos como grandes, ocorrem nas edificações residenciais, como mostram os dados do Corpo de Bombeiros da Polícia Militar do Estado de São Paulo (Figura 42).

A introdução de novos produtos e sistemas construtivos no mercado nacional sem certificação pode contribuir na falta de qualidade e consequentemente na falta de segurança nas edificações e os riscos de incêndio podem aumentar potencialmente. Por isso torna-se necessário o conhecimento prévio do comportamento de reação e resistência ao fogo desses produtos, a fim de garantir a qualidade técnica e a segurança dos usuários.

\subsubsection{Instruções técnicas do Corpo de Bombeiros de SP}

Por meio das Instruções Técnicas do Corpo de Bombeiros de cada estado que são estabelecidos os parâmetros para a segurança contra incêndio com base na regulamentação estadual em vigor. Além disso, na maioria das vezes, estabelece-se um convênio com os municípios, onde o Corpo de bombeiros presta serviços de avaliações de projetos e inspeções nas edificações.

No estado de São Paulo, os edifícios de uso residencial exclusivamente unifamiliares com até dois pavimentos, com acessos independentes e com área inferior a $750 \mathrm{~m}^{2}$, são isentos de medidas passivas e ativas de proteção contra incêndios.

\subsubsection{NBR 15575/2013}

A norma de desempenho ABNT NBR 15.575:2013 estabelece requisitos e critérios para a produção de componentes e sistemas para a construção de unidades habitacionais independente dos materiais constituídos e sistemas construtivos. O foco da norma está no atendimento aos requisitos dos usuários e compreende questões como segurança, habitabilidade e sustentabilidade, a saber: desempenho térmico; desempenho acústico; desempenho lumínico; estanqueidade; saúde, higiene e qualidade do ar; funcionalidade, acessibilidade, 
conforto tátil e antropodinâmico; segurança contra incêndio; segurança estrutural; segurança no uso e operação; durabilidade, manutenibilidade e impacto ambiental. Também se considera o comportamento em uso do edifício, a fim de se atender a uma vida útil de projeto (VUP) mínima exigida.

A norma contempla todas as tipologias de edifícios residenciais (unifamiliar, isolada, geminada, assobradada e sobreposta), além dos edifícios multifamiliares e de múltiplos pavimentos.

A ABNT NBR 15575:2013 está dividida em seis partes que compreendem além dos requisitos gerais do edifício como um todo, requisitos para seus sistemas: estruturais, pisos, vedação vertical interior e exterior, coberturas e instalações. Para cada sistema são estabelecidos requisitos (exigências qualitativas) e critérios (exigências quantitativas) mínimos de desempenho que devem ser atendidos. A avaliação do desempenho deve considerar as premissas de projeto básicas para cada requisito (ASSOCIAÇÃO BRASILEIRA DE NORMAS TÉCNICAS, 2013).

Os requisitos da segurança contra incêndio são:

a) dificultar o princípio de incêndio;

b) facilitar a fuga em situação de incêndio;

c) dificultar a inflamação generalizada;

d) dificultar a propagação de incêndio;

e) segurança estrutural em situação de incêndio;

f) sistema de extinção e sinalização de incêndio;

g) combate a incêndio com água; e

h) combate a incêndio com extintores.

Dentre os oito requisitos acima listados, cinco podem ser relacionadas às ações de proteção passiva e, mas somente quatro serão comentadas a seguir.

Para dificultar o risco de princípio de incêndio os critérios exigidos são relacionados à proteção contra descargas atmosféricas (quando aplicável) e redução de risco de ignição nas instalações elétricas e de vazamento de gás. Em ambientes enclausurados, devem ser atendidas a norma ABNT NBR 15526:2012 e outras normas brasileiras aplicáveis. Deve-se considerar os diversos componentes 
e instalações que podem estar alojados nos entre-forros e áticos para evitar o princípio de incêndio provindo de descargas atmosféricas e falhas nas instalações elétricas e instalações de gás (ASSOCIAÇÃO BRASILEIRA DE NORMAS TÉCNICAS, 2013).

Para não ocorrer à inflamação generalizada no ambiente de origem do incêndio e a geração de fumaça excessiva que impeça a fuga dos usuários, os sistemas e o edifício como um todo devem atender os requisitos e critérios estabelecidos a seguir:

- Sistema de pisos

O sistema de pisos é composto por um conjunto parcial ou total de camadas (camada estrutural, camada de contrapiso, camada de fixação etc.) com função de estrutura, vedação ou tráfego. Para atender os requisitos e critérios da norma o sistema de piso deve ser avaliado conforme os métodos de ensaio previstos e os elementos construtivos devem ser classificados de acordo com as Tabelas 13 e 14 .

- Requisito: Reação ao fogo da face inferior do sistema de piso (camada estrutural):

- I ou II A, quando estiverem associados a espaços de cozinha;

- I, II A ou III A, quando estiverem associados a outros locais internos da habitação, exceto cozinhas;

- I ou II A, quando estiverem associados a outros locais de uso comum da edificação;

- I ou II A, quando estiverem associadas ao interior de escadas, de poços de elevadores e monta-cargas e de átrios, porém, com Dm $\geq 100$ (densidade específica óptica máxima de fumaça);

- os materiais empregados nas camadas dos sistemas de piso, desde que protegidos por barreiras incombustíveis que possam desagregar em situação de incêndio, ou que contenham juntas através das quais o miolo pode ser afetado devem-se classificar como I, II A e III A.

- Requisito: Reação ao fogo da face superior do sistema de piso (camada estrutural): 
- a face superior do entrepiso, composto pela camada de acabamento incluindo todas as camadas subsequentes que podem interferir no comportamento de reação ao fogo, deve classificar-se como I, II A, III A ou IV A em todas as áreas da unidade habitacional, com exceção do interior das escadas onde deve classificar-se como I ou II A, com Dm $\leq 100$ e são classificadas conforme a Tabela 13.

Tabela 13 - Classificação dos materiais conforme o método ABNT NBR 9442

\begin{tabular}{|c|c|c|c|}
\hline \multirow{2}{*}{ Classe } & \multicolumn{3}{|c|}{ Método de ensaio } \\
\hline & ISO 1182 & ABNT NBR 9442 & ASTM E662 \\
\hline 1 & $\begin{array}{c}\text { Incombustível } \\
\Delta \mathrm{T} \leq 30^{\circ} \mathrm{C} \\
\Delta \mathrm{m} \leq 50 \% \\
\mathrm{t}_{f} \leq 10 \mathrm{~s}\end{array}$ & - & - \\
\hline II A & Combustível & Ip $\leq 25$ & $\mathrm{Dm} \leq 450$ \\
\hline II B & Combustível & $\mathrm{Ip} \leq 25$ & $\mathrm{Dm}>450$ \\
\hline III A & Combustível & $25<$ lp $\leq 75$ & $\mathrm{Dm} \leq 450$ \\
\hline III B & Combustível & $25<$ lp $\leq 75$ & $\mathrm{Dm}>450$ \\
\hline IV A & Combustível & $75<1 p \leq 150$ & $\mathrm{Dm} \leq 450$ \\
\hline IV B & Combustível & $75<1 p \leq 150$ & $\mathrm{Dm}>450$ \\
\hline V A & Combustível & $150<1 p \leq 400$ & $\mathrm{Dm} \leq 450$ \\
\hline V B & Combustível & $150<l p \leq 400$ & $\mathrm{Dm}>450$ \\
\hline VI & Combustível & Ip > 400 & - \\
\hline
\end{tabular}

Fonte: ABNT NBR 15575 (2013)

Legenda:

Ip - Índice de propagação da chama

Dm - Densidade específica óptica da fumaça

$\Delta T$ - Variação de temperatura do forno

$\Delta \mathrm{m}$ - Variação de massa do corpo de prova

tf - Tempo de flamejamento do corpo de prova 
Tabela 14 - Classificação dos materiais conforme o método EN 13823

\begin{tabular}{|c|c|c|c|}
\hline \multirow[b]{2}{*}{ Classe } & \multicolumn{3}{|c|}{ Método de ensaio } \\
\hline & ISO 1182 & EN 13823 & $\begin{array}{l}\text { ISO 11925-2 } \\
\text { (exp. = 30s) }\end{array}$ \\
\hline I & $\begin{array}{c}\text { Incombustível } \\
\Delta \mathrm{T} \leq 30^{\circ} \mathrm{C} \\
\Delta \mathrm{m} \leq 50 \% \\
\mathrm{t}_{\mathrm{f}} \leq 10 \mathrm{~s}\end{array}$ & - & - \\
\hline II A & Combustível & $\begin{array}{c}\text { FIGRA } \leq 120 \mathrm{~W} / \mathrm{s} \\
\text { LSF }<\text { canto do corpo de prova } \\
\text { THR600s } \leq 7,5 \mathrm{MJ} \\
\text { SMOGRA } \leq 180 \mathrm{~m}^{2} / \mathrm{s}^{2} \text { e TSP60s } \leq 200 \mathrm{~m}^{2}\end{array}$ & $\mathrm{FS} \leq 150 \mathrm{~mm}$ em $60 \mathrm{~s}$ \\
\hline II B & Combustível & $\begin{array}{c}\text { FIGRA } \leq 120 \mathrm{~W} / \mathrm{s} \\
\text { LSF }<\text { canto do corpo de prova } \\
\text { THR600s } \leq 7,5 \mathrm{MJ} \\
\text { SMOGRA }>180 \mathrm{~m}^{2} / \mathrm{s}^{2} \text { e TSP } 60 \mathrm{~s}>200 \mathrm{~m}^{2}\end{array}$ & $\mathrm{FS} \leq 150 \mathrm{~mm}$ em $60 \mathrm{~s}$ \\
\hline III A & Combustível & $\begin{array}{c}\text { FIGRA } \leq 250 \mathrm{~W} / \mathrm{s} \\
\text { LSF }<\text { canto do corpo de prova } \\
\text { THR600s } \leq 7,5 \mathrm{MJ} \\
\text { SMOGRA } \leq 180 \mathrm{~m}^{2} / \mathrm{s}^{2} \text { e TSP60s } \leq 200 \mathrm{~m}^{2}\end{array}$ & $\mathrm{FS} \leq 150 \mathrm{~mm}$ em $60 \mathrm{~s}$ \\
\hline III B & Combustível & $\begin{array}{c}\text { FIGRA } \leq 250 \mathrm{~W} / \mathrm{s} \\
\text { LSF }<\text { canto do corpo de prova } \\
\text { THR600s } \leq 7,5 \mathrm{MJ} \\
\text { SMOGRA }>180 \mathrm{~m}^{2} / \mathrm{s}^{2} \text { e TSP } 60 \mathrm{~s}>200 \mathrm{~m}^{2}\end{array}$ & $\mathrm{FS} \leq 150 \mathrm{~mm}$ em $60 \mathrm{~s}$ \\
\hline IV $A$ & Combustível & $\begin{array}{c}\text { FIGRA } \leq 750 \mathrm{~W} / \mathrm{s} \\
\text { SMOGRA } \leq 180 \mathrm{~m}^{2} / \mathrm{s}^{2} \mathrm{e} \text { TSP60s } \leq 200 \mathrm{~m}^{2}\end{array}$ & $\mathrm{FS} \leq 150 \mathrm{~mm}$ em $60 \mathrm{~s}$ \\
\hline IV B & Combustível & $\begin{array}{c}\text { FIGRA } \leq 750 \mathrm{~W} / \mathrm{s} \\
\text { SMOGRA }>180 \mathrm{~m}^{2} / \mathrm{s}^{2} \text { e TSP } 60 \mathrm{~s}>200 \mathrm{~m}^{2}\end{array}$ & $\mathrm{FS} \leq 150 \mathrm{~mm}$ em $60 \mathrm{~s}$ \\
\hline $\mathrm{VA}$ & Combustível & $\begin{array}{c}\text { FIGRA } \leq 750 \mathrm{~W} / \mathrm{s} \\
\text { SMOGRA } \leq 180 \mathrm{~m}^{2} / \mathrm{s}^{2} \text { e TSP60s } \leq 200 \mathrm{~m}^{2}\end{array}$ & $\mathrm{FS} \leq 150 \mathrm{~mm}$ em $20 \mathrm{~s}$ \\
\hline V B & Combustível & $\begin{array}{c}\text { FIGRA } \leq 750 \mathrm{~W} / \mathrm{s} \\
\text { SMOGRA }>180 \mathrm{~m}^{2} / \mathrm{s}^{2} \text { e TSP } 60 \mathrm{~s}>200 \mathrm{~m}^{2}\end{array}$ & $\mathrm{FS} \leq 150 \mathrm{~mm}$ em $20 \mathrm{~s}$ \\
\hline VI & - & - & $\mathrm{FS}>150 \mathrm{~mm}$ em 20s \\
\hline
\end{tabular}

Fonte: ABNT NBR 15575 (2013, pag.10)

Legenda:

- FIGRA - Índice da taxa de desenvolvimento de calor

- LFS - Propagação lateral da chama

- THR600s - Liberação total de calor do corpo de prova nos primeiros 600 s de exposição às chamas

- TPS600s - Produção total do calor do corpo de prova nos primeiros 600 s de exposição às chamas

- SMOGRA - Taxa de desenvolvimento de fumaça, correspondendo ao máximo do quociente de produção de fumaça do corpo de prova e o tempo de sua ocorrência

- FS - Tempo que a frente da chama leva para atingir a marca de $150 \mathrm{~mm}$ indicada na face do material ensaiado 
- Sistemas de vedações verticais internas e externas (SVVIE)

- Reação ao fogo da face interna dos sistemas de vedações verticais e respectivos miolos isolantes térmicos e absorventes acústicos. As superfícies internas das vedações verticais externas (fachadas) e ambas as superfícies das vedações verticais internas devem ser classificadas de acordo com os métodos das Tabelas 13 e 14:

- I, II A ou III A, quando estiverem associadas a espaços de cozinha;

- I, II A, III A ou IV A, quando estiverem associadas a outros locais internos da habitação, exceto cozinhas;

- I ou II A, quando estiverem associadas a locais de uso comum da edificação;

- I ou II A, quando estiverem associadas ao interior das escadas, porém com $\mathrm{Dm}<100$. Os materiais empregados no meio das paredes (miolo) externas ou internas - devem ser classificados como I, II A ou III A (ASSOCIAÇÃO BRASILEIRA DE NORMAS TÉCNICAS, 2013 - Parte 4, pg.18 e 19).

- Reação ao fogo da face externa das vedações verticais que compõem a fachada

- As superfícies externas da fachada (paredes externas) devem ser classificadas como I ou II B conforme os métodos de ensaios das Tabelas 13 e 14, para assegurar a estanqueidade e isolamento ao fogo.

Para dificultar a propagação do incêndio, da fumaça e preservar a estabilidade estrutural entre os sistemas ou elementos de vedação entre pavimentos, compostos por entre-pisos e elementos estruturais associados, que integram as edificações habitacionais, devem atender aos critérios de resistência ao fogo e selagem dos serviços que os transpõem, também como as escadas, elevadores e monta-cargas. Os sistemas ou elementos de vedação vertical (SVVIE) que integram as edificações habitacionais. Sistemas ou elementos de vedação entre pavimentos, compostos por entrepisos e elementos estruturais associados.

- Requisito: Resistência ao fogo de elementos de compartimentação entre pavimentos e elementos estruturais associados 
- Os valores de resistência ao fogo que devem ser atendidos são definidos em função da altura da edificação, entendida como a medida em metros do piso mais baixo ocupado ao piso do último pavimento (exceto áreas técnicas sem aproveitamento para quaisquer atividades ou permanência humana). Para os edifícios habitacionais unifamiliares, isolados, assobradados ou unidades sobrepostas $<12 \mathrm{~m}$ de altura, o critério de resistência ao fogo dos elementos corta-fogo (isolamento térmico, estanqueidade e estabilidade) é de $30 \mathrm{~min}$. conforme a análise do projeto estrutural do material utilizado e a ABNT NBR 5628.

- Requisito: Selagem corta-fogo nas prumadas elétricas, hidráulicas e de serviços

- As aberturas para as transposições das instalações elétricas e hidráulicas nos pisos devem ser dotadas de selagem corta-fogo, com o mesmo tempo de resistência ao fogo requerido para o sistema de piso, levando em consideração a altura da edificação e ser comprovada por meio de ensaios conforme a ABNT NBR 6479:1992;

- As tubulações de materiais poliméricos com diâmetro interno superior a $40 \mathrm{~mm}$ que atravessam o sistema de piso devem ser seladas ao redor de toda tubulação para evitar a passagem de chamas e fumaça e devem ser comprovados por meio de ensaios conforme a ABNT NBR 6479:1992. Tais selos podem ser substituídos por prumadas enclausuradas;

- As tubulações de ventilação e ar-condicionado que transpassarem os pisos devem ser dotadas de registros corta-fogo, devidamente instalados no nível de cada piso, apresentando resistência ao fogo igual à requerida para o sistema de piso e dotados de acionamentos automáticos comandados por sistema de detecção automática de fumaça que esteja de acordo com a ABNT NBR 17240:2010. O tempo de resistência ao fogo de no mínimo 120 min. para todas as tubulações, porém não inferior ao tempo de 
resistência ao fogo requerido para o edifício e devem ser comprovadas por meio de ensaios conforme a ABNT NBR 6479:1192. Tubulação que não pode receber registros corta-fogo instalados no nível do piso deve ser comprovada por meio de ensaios conforme a ISO 6944-1.

- Requisito: Resistência ao fogo das prumadas de serviços

- As prumadas totalmente enclausuradas por onde passam as instalações de serviço, como esgoto e águas pluviais, não necessitam ser seladas, desde que as paredes que as componham sejam corta-fogo e apresentem resistência ao fogo no mínimo idêntica àquela requerida para o piso. A resistência ao fogo das paredes corta-fogo deve ser comprovada por meio de ensaios conforme a ABNT NBR 10636:1989.

- Os dutos de ventilação e exaustão permanentes de banheiros, integralmente compostos por materiais incombustíveis, ou seja, Classe I, conforme Tabela 13, e cujas paredes ou tubulações que os constituam sejam corta-fogo, apresentando no mínimo a mesma resistência ao fogo do sistema de piso, devem ter todas as suas derivações nos banheiros protegidas por grades de material intumescente, cuja resistência ao fogo mínima seja idêntica à do sistema de piso. Caso estas condições não sejam atendidas, as tomadas de ar em cada derivação devem ser protegidas por registros corta-fogo.

- A resistência ao fogo de materiais Classe I (incombustíveis), paredes corta-fogo e grades, consideradas um tipo de vedador, devem ser comprovadas por meio de ensaios conforme o método de ensaio ISO 1182:2010, ABNT NBR 10636:1989 e ABNT NBR 6479: respectivamente.

- Os dutos de exaustão de lareiras, churrasqueiras, varandas gourmet e similares devem ser integralmente constituídos por materiais Classe I (incombustíveis), conforme Tabela 13, e devem ser dispostos de forma a não implicarem risco de propagação de incêndio entre pavimentos, ou no próprio pavimento onde se 
originam. Devem também atender somente uma lareira ou churrasqueira e/ou as conexões com prumada coletiva e ser comprovados por meio de ensaios conforme o método de ensaio ISO 1182:2010 e análise de projeto.

- Escadas, elevadores e monta-cargas

- As escadas devem ser enclausuradas com paredes e portas cortafogo e ter resistência ao fogo das paredes de no mínimo $120 \mathrm{~min}$., para edifícios até $120 \mathrm{~m}$ de altura. Devem ser feitas análise de projeto e avaliações de resistência ao fogo de acordo com as ABNT NBR 10636:2010 e ABNT NBR 6479:1992 respectivamente, para elementos fixos e móveis.

- Sistemas de vedações verticais internas e externas estruturais (SVVIE)

- Requisito: Resistência ao fogo de elementos estruturais e de compartimentação

- Os sistemas ou elementos de vedação vertical que integram as edificações habitacionais devem atender à ABNT NBR 14432:2001 e as normas brasileiras aplicáveis ou normas internacionais aplicáveis quando não há norma nacional de acordo com o tipo de estrutura, para controlar os riscos de propagação do incêndio e preservar a estabilidade estrutural da edificação em situação de incêndio. $O$ tempo requerido de resistência ao fogo (TRRF) deve ser considerar os critérios de avaliação relativos à estabilidade, estanqueidade e isolação térmica, e levar em conta a altura da edificação;

- No caso de unidade habitacional unifamiliar, isolada, até dois pavimentos, o TRRF 30 min. para os SVVE somente na cozinha e ambiente fechado que abrigue equipamento de gás;

- Para a compartimentação devem se tomar medidas de proteção, o que inclui o uso de portas e selos corta-fogo para uso residencial até $6,00 \mathrm{~m}$ de altura e devem ter TRRF $30 \mathrm{~min}$. de resistência ao fogo, conforme estabelecida na ABNT NBR 15575:2013(Parte 4);

- As paredes estruturais devem apresentar TRRF mínimo de 30 min., para edificações habitacionais de até cinco pavimentos; 
- As paredes de geminação (paredes entre unidades) de casas térreas geminadas e de sobrados geminados, bem como as paredes entre unidades habitacionais e que fazem divisa com as áreas comuns nos edifícios multifamiliares, são elementos de compartimentação horizontal e devem apresentar TRRF mínimo de 30 min., no caso de edifícios até cinco pavimentos;

- As paredes de geminação também devem prever componentes ou elementos que se prolonguem até a face inferior do telhado, sem presença de vazios e com resistência mínima de 30 min.

A resistência ao fogo dos elementos estruturais constituintes do SVVIE deve ser comprovada em ensaios realizados conforme a ABNT NBR 5628:2001. Para os elementos sem função estrutural constituintes do SVVIE, a resistência ao fogo deve ser comprovada por meio de ensaios realizados conforme a ABNT NBR 10636:1989 (ASSOCIAÇÃO BRASILEIRA DE NORMAS TÉCNICAS, 2013 - Parte 4 pag.22).

- $\quad$ Sistemas de coberturas (SC)

- Requisito: Reação ao fogo dos materiais de revestimento e acabamento

Dificultar a propagação de chamas no ambiente de origem do incêndio e não prejudicar a visibilidade durante a fuga dos ocupantes em situações de incêndio.

- A face interna do sistema de cobertura composto pela superfície inferior das coberturas e subcoberturas, ambas as superfícies de forros, ambas as superfícies de materiais isolantes térmicos e absorventes acústicos e outros materiais incorporados devem classificar-se como I, II A ou III A, de acordo com a Tabela 15, conforme o método de avaliação previsto. No caso de cozinhas, a classificação deve ser I ou II A.

Durante os ensaios, caso ocorra derretimento, desagregação, propagação e penetração de fogo o material deve seguir o método alternativo EN 13823 e seguir a classificação da Tabela 16. 
Tabela 15 - Classificação de materiais com base no método ANBT NBR 9442:1986

\begin{tabular}{c|c|c|c}
\hline \multirow{2}{*}{ Classe } & \multicolumn{3}{|c}{ Método de ensaio } \\
\cline { 2 - 4 } & ISO 1182 & ABNT NBR 9442 & ASTM E662 \\
\hline \multirow{3}{*}{ I } & Incombustível & & \\
& $\Delta \mathrm{T} \leq 30^{\circ} \mathrm{C} ;$ & - & - \\
& $\Delta \mathrm{m} \leq 50 \% ;$ & & $\mathrm{Dm} \leq 450$ \\
\hline II A & $\mathrm{t}_{\mathrm{f}} \leq 10 \mathrm{~s}$ & $\mathrm{Ip} \leq 25$ & $\mathrm{Dm} \leq 450$ \\
\hline III A & Combustível & $25<\mathrm{p} \leq 75$ & \\
\hline
\end{tabular}

Fonte: ABNT NBR 15575 (2013)

Legenda:

Ip - Índice de propagação da chama

Dm - Densidade específica óptica da fumaça

$\Delta T$ - Variação de temperatura do forno

$\Delta \mathrm{m}$ - Variação de massa do corpo de prova

tf - Tempo de flamejamento do corpo de prova

Tabela 16 - Classificação dos materiais de cobertura acordo com o método alternativo EN 13823:2010

\begin{tabular}{|c|c|c|c|}
\hline \multirow[b]{2}{*}{ Classe } & \multicolumn{3}{|c|}{ Método de ensaio } \\
\hline & ISO 1182 & EN 13823 & $\begin{array}{l}\text { ISO 11925-2 } \\
\text { (exp. = 30s) }\end{array}$ \\
\hline 1 & $\begin{array}{l}\text { Incombustível } \\
\begin{array}{c}\Delta \mathrm{T} \leq 30^{\circ} \mathrm{C} \\
\Delta \mathrm{m} \leq 50 \% \\
\mathrm{t}_{\mathrm{f}} \leq 10 \mathrm{~s}\end{array}\end{array}$ & - & - \\
\hline II A & Combustível & $\begin{array}{c}\text { FIGRA } \leq 120 \mathrm{~W} / \mathrm{s} \\
\text { LSF }<\text { canto do corpo de prova } \\
\text { THR600s } \leq 7,5 \mathrm{MJ} \\
\text { SMOGRA } \leq 180 \mathrm{~m}^{2} / \mathrm{s}^{2} \text { e TSP } 60 \mathrm{~s} \leq 200 \mathrm{~m}^{2}\end{array}$ & $\mathrm{FS} \leq 150 \mathrm{~mm}$ em $60 \mathrm{~s}$ \\
\hline III A & Combustível & $\begin{array}{c}\text { FIGRA } \leq 250 \mathrm{~W} / \mathrm{s} \\
\text { LSF }<\text { canto do corpo de prova } \\
\text { THR600s } \leq 7,5 \mathrm{MJ} \\
\text { SMOGRA } \leq 180 \mathrm{~m}^{2} / \mathrm{s}^{2} \text { e TSP } 60 \mathrm{~s} \leq 200 \mathrm{~m}^{2}\end{array}$ & $\mathrm{FS} \leq 150 \mathrm{~mm}$ em $60 \mathrm{~s}$ \\
\hline
\end{tabular}


Legenda:

FIGRA - Índice da taxa de desenvolvimento de calor

LFS - Propagação lateral da chama

THR600s - Liberação total de calor do corpo de prova nos primeiros 600 s de exposição às chamas TPS600s - Produção total do corpo de prova do corpo nos primeiros 600 s de exposição às chamas SMOGRA - Taxa de desenvolvimento de fumaça, correspondendo ao máximo do quociente de produção de fumaça do corpo de prova e o tempo de sua ocorrência

FS - Tempo que a frente da chama leva para atingir a marca de $150 \mathrm{~mm}$ indicada na face do material ensaiado

Tabela 17 - Classificação dos materiais do sistema de cobertura tendo como base o método ABNT NBR 9442

\begin{tabular}{c|c|c}
\hline \multirow{2}{*}{ Classe } & \multicolumn{2}{|c}{ Método de ensaio } \\
\cline { 2 - 3 } & ISO 1182 & ABNT NBR 9442 \\
\hline \multirow{3}{*}{ I } & Incombustível & \\
& $\Delta \mathrm{T} \leq 30^{\circ} \mathrm{C} ;$ & \\
& $\Delta \mathrm{m} \leq 50 \% ;$ & Ip $\leq 25$ \\
\hline II & $\mathrm{t}_{\mathrm{f}} \leq 10 \mathrm{~s}$ & $25<\mathrm{p} \leq 75$ \\
\hline
\end{tabular}

Fonte: ABNT NBR 15575 (2013)

Exigências similares, para desempenho de materiais de acabamento e revestimento, são determinadas igualmente para paredes e teto/forro, nesta mesma norma.

Obs.: Os ensaios para avaliação dos materiais devem considerar a maneira como são aplicados na edificação. Caso o material seja aplicado sobre substrato combustível, este deve ser incluído no ensaio. Caso o material seja aplicado a um substrato incombustível, o ensaio pode ser realizado utilizando-se substrato de placas de fibrocimento com $6 \mathrm{~mm}$ de espessura. Na impossibilidade de classificação conforme ABNT NBR 9442 ou conforme a Tabela 16 pode ser realizado o ensaio por meio do método Uniform Building Code Standard 26-3 (UBC 26-3) - Room fire test standard for interior of foam plastic systems, sendo os requisitos estabelecidos em termos do Índice de propagação superficial de chamas (ASSOCIAÇÃO BRASILEIRA DE NORMAS TÉCNICAS, 2013 - Parte-5 pag.15). 
- Requisito: reação ao fogo da face externa do sistema de cobertura das edificações

- A face externa do sistema de cobertura deve classificar-se como I, II ou III da Tabela 17.

Quando não há possibilidade de classificação pelos métodos da Tabela 18, devem-se adotar os seguintes critérios de avaliação:

a) propagação de chama interna e externa no sentido ascendente deve ser inferior a $700 \mathrm{~mm}$;

a) propagação de chama interna e externa no sentido descendente deve ser inferior a $600 \mathrm{~mm}$;

b) comprimento máximo interno e externo carbonizado devem ser inferiores a $800 \mathrm{~mm}$;

c) ocorrências de aberturas isoladas na cobertura devem ser inferiores ou iguais a $25 \mathrm{~mm} 2$;

d) soma de todas as aberturas na cobertura deve ser inferior a $4500 \mathrm{~mm}$;

e) propagação lateral não pode alcançar as extremidades do corpo de prova;

f) não pode ocorrer o desprendimento de gotas ou partículas em chamas;

g) não pode ocorrer a penetração de partículas em chamas no interior do sistema; - não pode ocorrer abrasamento interno do material da cobertura (ASSOCIAÇÃO BRASILEIRA DE NORMAS TÉCNICAS, 2013 - Parte-5 pag.17).

$\mathrm{Na}$ impossibilidade da avaliação dos materiais pelos métodos da Tabela 18 pode ser utilizado o método 1 da norma ENV 1187 - Test method for external fire performance to roof, considerando todos os detalhes construtivos do telhado incluindo a declividade, os recobrimentos mínimos das diferentes camadas e os detalhes de junção entre camadas e de fixação dos suportes de apoio (ASSOCIAÇÃO BRASILEIRA DE NORMAS TÉCNICAS, 2013 - Parte-5 pag.18).

- Requisito - Resistência ao fogo do sistema de cobertura

- A resistência ao fogo da estrutura do SC deve atender aos requisitos da ABNT NBR 14432, considerando um valor mínimo de $30 \mathrm{~min}$. para unidade habitacional unifamiliar geminada de até dois pavimentos; 
- Cozinha e ambiente fechado que abrigue o equipamento de gás, o valor da resistência ao fogo mínima do SC é de $30 \mathrm{~min}$.;

- No caso de unidade habitacional unifamiliar, isolada, de até dois pavimentos, o TRRF 30 min. somente na cozinha e em ambiente fechado que abriguem equipamento de gás;

- Os demais ambientes que o SC não atender a esta condição, deve ser previsto um septo vertical entre as unidades habitacionais, com resistência ao fogo mínima de $30 \mathrm{~min}$.;

- O projeto do SC deve devem prever componentes ou elementos que se prolonguem até a face inferior do telhado, sem presença de vazios e com resistência mínima de 30 min.

Dificultar a propagação entre pavimentos por meio de instalações hirossanitárias, aparentes, embutidas ou instaladas em dutos verticais tipo shafts, tem que ser constituídos de materiais que não propaguem chamas de acordo com a ISO 1182, além da análise do projeto.

○ Requisito - Evitar propagação de chamas entre pavimentos

A avaliação deve ser por meio da análise de projeto e verificação do material de acordo com a ISO 1182.

- Prumadas de esgoto sanitário e ventilação estiverem instaladas aparentes, fixadas em alvenaria ou no interior de dutos verticais (shafts), devem ser fabricadas com material não propagante de chamas.

Para dificultar a propagação de incêndio entre as unidades contíguas ou edificacões a norma de desempenho determina que a distância entre edifícios deve atender às condições de isolamento. O método de avaliação utilizado é por meio da análise do projeto e distâncias seguras, levando em conta a ignição-piloto por radiação e convecção através da cobertura.

Em termos gerais, para minimizar o risco de colapso estrutural da edificação em situação de incêndio, os sistemas e elementos construtivos devem atender a resistência ao fogo de $30 \mathrm{~min}$. de acordo com a ABNT NBR 14432 e as normas específicas de acordo com o tipo de estrutura, entretanto para a avaliação dos 
sistemas construtivos de madeira ainda não existe uma norma nacional específica e, portanto a ABNT NBR 15.575:2013 determina que o cálculo deve seguir o Eurocode 5.

Para o sistema construtivo de CLT às ações de proteção passiva relacionadas na norma ABNT NBR 15.575:2013 serão comentadas com maior profundidade e com maiores detalhes no capítulo cinco.

\subsection{Conclusão}

Os países apresentados, como a Austrália, o Reino Unido e os E.U.A têm em seus códigos construtivos nacionais recomendações específicas para a segurança contra incêndio para edificações residenciais unifamiliares (e para outros tipos de ocupação). Como observado, todos os países analisados apresentam intervenções semelhantes entre si, quanto aos requisitos de resistência ao fogo, risco de incêndio, distanciamento seguro entre edificações etc.

Estes códigos, quando baseados em desempenho, também permitem soluções e a aplicação de novos produtos, desde que estes atendam aos critérios exigidos pelos métodos de avaliação propostos.

A exemplo, países como o Reino Unido e os E.U.A já têm norma uma específica e requisitos inseridos nas regulamentações e códigos de construção civil, para sistemas construtivos de madeira que incluem os produtos de madeira engenheirada como o CLT.

Também foram detectadas situações de exigências mais rigorosas, como a instalação de sistema de chuveiros automáticos em residências, mesmo de pequeno porte e unifamiliares - demonstrando uma preocupação maior com a questão da segurança contra incêndio dentro de um contexto diferente do brasileiro (Felix; Ono, 2019).

O Quadro 02 apresenta um resumo comparativo dos requisitos e critérios dos regulamentos analisados da Austrália, do Reino Unido, dos E.U.A e do Brasil para atender a segurança contra incêndio. 
Embora o Brasil careça de uma legislação de segurança contra incêndio para as edificações de uso residencial exclusivamente unifamiliares, geminadas ou sobrepostas até dois pavimentos, a norma ABNT NBR 15.575:2013 estabelece requisitos e critérios com base no desempenho, permitindo assim que um grau de risco seja especificado e também que seja realizada uma avaliação do edifício de forma global, em vez de se concentrar em elementos individuais. Normas com base no desempenho possibilitam soluções alternativas para atender aos requisitos e critérios estabelecidos contribuindo assim para a introdução de novos produtos e sistemas construtivos no mercado nacional, como o CLT, evitando e/ou diminuindo os riscos potenciais de ocorrência incêndio .

Seguem abaixo os Quadros 3 com o resumo dos requisitos de proteção ao fogo para os sistemas construtivos de madeira em geral e o Quadro 4 somente para o sistema construtivo em CLT dos países analisados.

Quadro 2 - Resumo das exigências para segurança contra incêndio em edifícios residenciais unifamiliares, geminados ou sobrepostos até dois pavimentos

\begin{tabular}{|c|c|c|c|c|c|}
\hline Países & & Austrália & Inglaterra & E.U.A & Brasil \\
\hline $\begin{array}{l}\text { Documento } \\
\text { normativo }\end{array}$ & & $\mathrm{BCA}$ & $\begin{array}{c}\text { (Approved Document B: } \\
\text { Fire Safety) }\end{array}$ & IBC & $\begin{array}{l}\text { (ABNT NBR } \\
15575: 2013 \text { ) }\end{array}$ \\
\hline- & \multicolumn{5}{|c|}{ Resistência ao Fogo (hrs.) } \\
\hline \multirow{2}{*}{ Paredes externas $^{1}$} & SA $^{*}$ & 60 & 30 & 120 & 30 \\
\hline & $\mathbf{C A}^{\star \star}$ & 60 & 30 & 60 & $\mathrm{NE}$ \\
\hline \multirow{2}{*}{ Paredes internas $^{2}$} & SA $^{*}$ & 60 & 30 & 60 & 30 \\
\hline & $\mathrm{CA}^{\star \star}$ & 30 & 30 & 30 & $\mathrm{NE}$ \\
\hline $\begin{array}{l}\text { Distância entre } \\
\text { edificações }\end{array}$ & & 0,9 & 1,00 & NE & NE \\
\hline $\begin{array}{c}\text { Exigido } \\
\text { Chuveiro automático }\end{array}$ & & não & não & não ${ }^{3}$ & NE \\
\hline $\begin{array}{c}\text { Exigido } \\
\text { Alarme de incêndio }\end{array}$ & & não & $\operatorname{sim}$ & $\operatorname{sim}$ & NE \\
\hline $\begin{array}{c}\text { Exigido } \\
\text { Detector de fumaça }\end{array}$ & & $\operatorname{sim}$ & $\operatorname{sim}$ & $\operatorname{sim}$ & NE \\
\hline
\end{tabular}

Fonte: da autora (2019)

Nota:

1 - Paredes externas estruturais e de compartimentação

2 - Paredes internas estruturais, de compartimentação e corta-fogo

3 - Para construção tipo IV (Heavy Timber, HT) são exigidos chuveiros automáticos, independente da altura e área do edifício

$S A^{*}$ - Sem sistema de chuveiro automático

$\mathrm{CA}^{* *}$ - Com sistema de chuveiro automático

$\mathrm{NE}^{\star}$ - Não especifica 
Quadro 3 - Requisitos de proteção ao fogo para sistemas construtivos de madeira em geral

\begin{tabular}{|c|c|c|c|c|c|}
\hline \multicolumn{6}{|c|}{ Resumo dos requisitos de proteção ao fogo para sistemas construtivos de madeira em geral } \\
\hline \multicolumn{2}{|c|}{ Austrália } & \multicolumn{2}{|c|}{ Reino Unido } & USA & Brasil \\
\hline \multicolumn{2}{|c|}{ National Construction Code (NCC) } & \multicolumn{2}{|c|}{ The Building Regulation 2010} & International & ABNT NBR \\
\hline $\begin{array}{c}\text { Prescritivo } \\
\text { (Deemed to } \\
\text { Satisfy Solution) }\end{array}$ & $\begin{array}{c}\text { Solução } \\
\text { alternativa de } \\
\text { desempenho } \\
\text { (Performance } \\
\text { Solution) }\end{array}$ & $\begin{array}{l}\text { Requisitos } \\
\text { mínimos } \\
\text { exigidos }\end{array}$ & $\begin{array}{c}\text { Forma } \\
\text { alternativa }\end{array}$ & & \\
\hline $\begin{array}{l}\text { Paredes externas } \\
\text { e de } \\
\text { compartimentação } \\
\text { entre unidades, } \\
\text { incluindo todos os } \\
\text { componentes } \\
\text { incorporados nos } \\
\text { mesmos, como } \\
\text { revestimento da } \\
\text { fachada, a } \\
\text { estrutura e o } \\
\text { isolamento do } \\
\text { pavimento e a } \\
\text { estrutura do piso } \\
\text { de poços de } \\
\text { elevador (quando } \\
\text { houver): } \\
\text { Materiais não } \\
\text { combustíveis }\end{array}$ & $\begin{array}{l}\text { O elemento em } \\
\text { madeira: } \\
\text { - resistência ao } \\
\text { fogo não inferior a } \\
\text { FRL } 45 \text { ou deve } \\
\text { ser protegido com } \\
\text { material } \\
\text { incombustível. }\end{array}$ & $\begin{array}{l}\text { Parede de } \\
\text { compartime } \\
\text { ntação: } \\
\text { - não } \\
\text { precisa ser } \\
\text { necessaria } \\
\text { mente } \\
\text { construída } \\
\text { em } \\
\text { alvenaria. }\end{array}$ & $\begin{array}{l}\text { - Não há } \\
\text { obrigação de } \\
\text { adotar qualquer } \\
\text { solução } \\
\text { particular } \\
\text { contida em um } \\
\text { documento } \\
\text { aprovado, } \\
\text { desde que seja } \\
\text { cumprido o } \\
\text { requisito do } \\
\text { regulamento. } \\
\text { - Normas } \\
\text { Britânicas } \\
\text { apropriadas e / } \\
\text { ou Normas } \\
\text { Europeias } \\
\text { também são } \\
\text { aceitos como } \\
\text { uma forma de } \\
\text { cumprir os } \\
\text { requisitos dos } \\
\text { regulamentos } \\
\text { de construção } \\
\text { (Approved } \\
\text { Document B, } \\
\text { 2010). }\end{array}$ & $\begin{array}{l}\text { Edificações } \\
\text { com } \\
\text { sistemas } \\
\text { construtivos } \\
\text { de madeira } \\
\text { são } \\
\text { comumente } \\
\text { classificadas } \\
\text { no Tipo III, } \\
\text { IV, V. }\end{array}$ & $\begin{array}{l}\text { - Norma de } \\
\text { desempenh } \\
\text { o } \\
\text { estabelece } \\
\text { requisitos } \\
\text { para } \\
\text { edifícios } \\
\text { habitacionai } \\
\text { s, } \\
\text { independen } \\
\text { te do } \\
\text { material } \\
\text { construtivo } \\
\text { utilizado; } \\
\text { - Atender } \\
\text { aos critérios } \\
\text { exigidos } \\
\text { e/ou as } \\
\text { referências } \\
\text { de normas } \\
\text { técnicas } \\
\text { nacionais e } \\
\text { internaciona } \\
\text { is } \\
\text { indicadas, } \\
\text { para } \\
\text { sistemas } \\
\text { construtivos } \\
\text { de madeira } \\
\text { em situação } \\
\text { de incêndio } \\
\text { seguir o } \\
\text { Eurocode } 5\end{array}$ \\
\hline $\begin{array}{l}\text { Barreira de } \\
\text { proteção: } \\
\text { Espessura mínima } \\
\text { da madeira FRL } \\
60-0-0: 45 \mathrm{~mm} \\
\text { FRL } 60-60 \text { - 0: } \\
55 \mathrm{~mm}\end{array}$ & & $\begin{array}{l}\text { Barreiras de } \\
\text { cavidades } \\
\text { fornecidas } \\
\text { em torno } \\
\text { das } \\
\text { aberturas: } \\
\text { - pela } \\
\text { própria } \\
\text { estrutura da } \\
\text { janela ou } \\
\text { porta; } \\
\text { - estrutura } \\
\text { de aço ou } \\
\text { de madeira, }\end{array}$ & & \begin{tabular}{|l|} 
As alturas \\
permitidas \\
para o grupo \\
$\mathrm{R}$ \\
(residencial), \\
em sistemas \\
construtivos \\
de madeira: \\
- sem \\
sistema de \\
chuveiros \\
elétricos até \\
$19,81 \mathrm{~m} ;$
\end{tabular} & \\
\hline
\end{tabular}




\begin{tabular}{|c|c|c|}
\hline & $\begin{array}{l}\text { pelo menos } \\
38 \\
\text { milímetros } \\
\text { de } \\
\text { espessura }\end{array}$ & \begin{tabular}{|l} 
- com \\
sistema de \\
chuveiros \\
automáticos \\
até $25,9 \mathrm{~m}$.
\end{tabular} \\
\hline $\begin{array}{l}\text { Paredes das } \\
\text { edificações classe } \\
1: \\
\text { não serem } \\
\text { atravessadas por } \\
\text { elementos de } \\
\text { madeira ou } \\
\text { outro material } \\
\text { combustível, } \\
\text { exceto por } \\
\text { sarrafos de } \\
\text { telhado com } \\
\text { dimensões de } \\
75 \times 50 \text { mm ou } \\
\text { menos }\end{array}$ & $\begin{array}{l}\text { Materiais } \\
\text { combustívei } \\
\text { s, como a } \\
\text { madeira, ter } \\
\text { o controle } \\
\text { de } \\
\text { propagação } \\
\text { do fogo no } \\
\text { interior da } \\
\text { edificação: } \\
\text { - a taxa de } \\
\text { liberação de } \\
\text { calor e a } \\
\text { taxa de } \\
\text { crescimento } \\
\text { do fogo } \\
\text { devem } \\
\text { atender a } \\
\text { classificaçã } \\
\text { o conforme } \\
\text { os ensaios } \\
\text { BS 476-6 } \\
\text { (BSI, 1989) } \\
\text { e BS 476-7 } \\
\text { (BSI, 1997), } \\
\text { respectivam } \\
\text { ente. }\end{array}$ & $\begin{array}{l}\text { As unidades } \\
\text { de habitação } \\
\text { em } \\
\text { residências } \\
\text { de duas } \\
\text { famílias } \\
\text { devem ser } \\
\text { separadas } \\
\text { uma da } \\
\text { outra: - } \\
\text { elementos } \\
\text { construídos } \\
\text { com } \\
\text { barreiras } \\
\text { corta-fogo, } \\
\text { com uma } \\
\text { resistência } \\
\text { ao fogo não } \\
\text { inferior a } 60 \\
\text { min. } \\
\text { - com } \\
\text { sistema de } \\
\text { chuveiros } \\
\text { automático a } \\
\text { resistência } \\
\text { ao fogo } 30 \\
\text { min. } \\
\end{array}$ \\
\hline $\begin{array}{l}\text { Para instalações: } \\
\text { qualquer elemento } \\
\text { combustível não } \\
\text { deve estar } \\
\text { localizado a } \\
\text { menos de } 100 \mathrm{~mm}\end{array}$ & & \begin{tabular}{|l} 
Paredes \\
externas tipo \\
III ou IV : \\
- resistência \\
ao fogo de 2 \\
horas. \\
Tipo V 1 \\
hora e \\
desde a \\
fundação \\
até não \\
menos de \\
30 \\
polegadas \\
(760 mm) \\
acima do \\
telhado, \\
exceto \\
quando não \\
é exigido.
\end{tabular} \\
\hline $\begin{array}{l}\text { Elementos } \\
\text { destinados para a } \\
\text { passagem de luz } \\
\text { natural na } \\
\text { cobertura } \\
\text { combustível: }\end{array}$ & & \begin{tabular}{|l} 
Paredes \\
internas: \\
- resistência \\
ao fogo \\
mínima de \\
60. \\
\end{tabular} \\
\hline
\end{tabular}




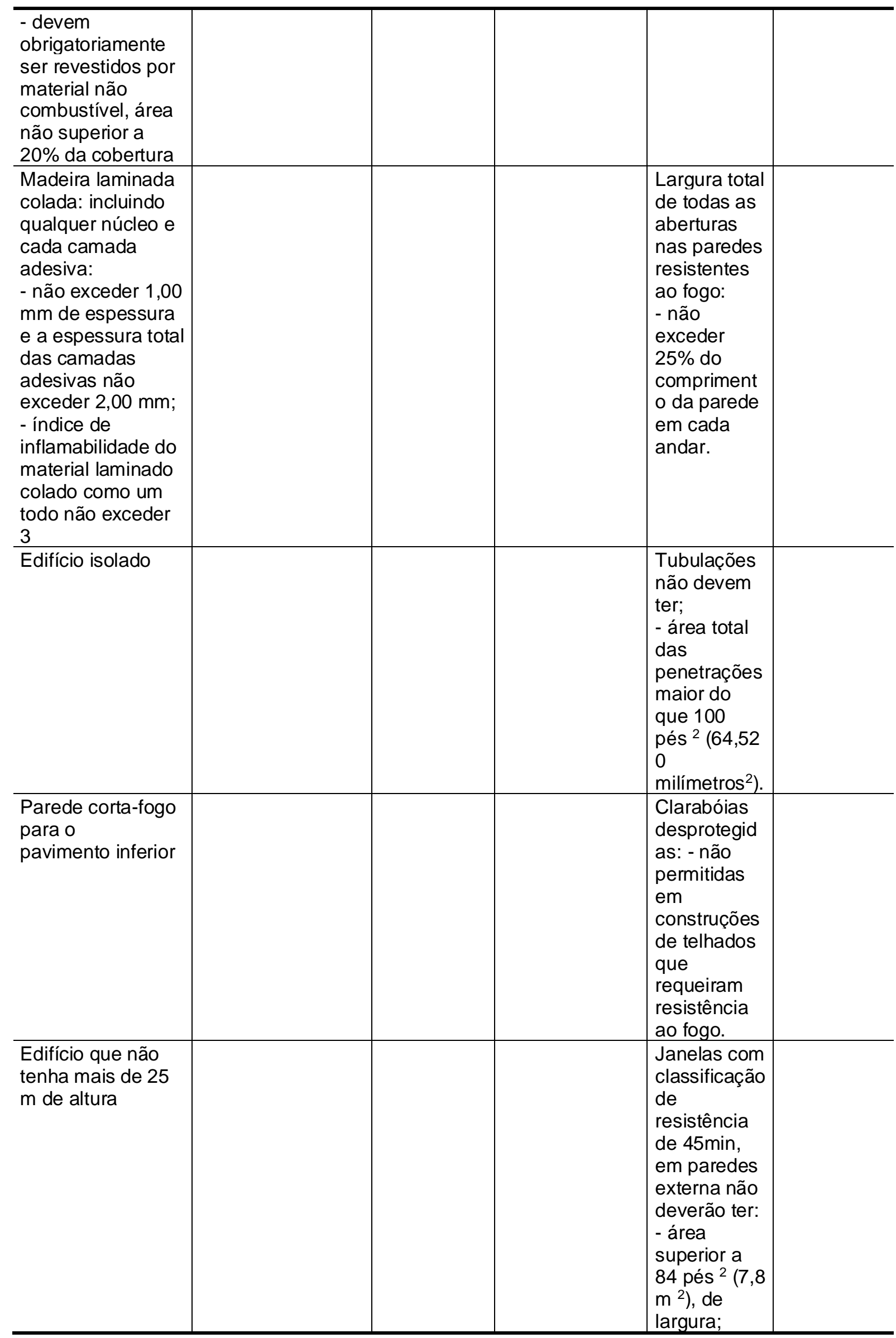




\begin{tabular}{|c|c|}
\hline & $\begin{array}{l}\text { - altura } \\
\text { maiores que } \\
12 \text { pés } \\
(3660 \mathrm{~mm}) . \\
\end{array}$ \\
\hline $\begin{array}{l}\text { Edifício que } \\
\text { possua um } \\
\text { sistema de } \\
\text { chuveiros } \\
\text { automáticos }\end{array}$ & $\begin{array}{l}\text { Distância } \\
\text { segura entre } \\
\text { edificações: } \\
\text { - mínimo } \\
1,5 m \text { para } \\
\text { resistência } \\
\text { de uma hora } \\
\end{array}$ \\
\hline $\begin{array}{l}\text { - Aumento do nível } \\
\text { de segurança } \\
\text { exigido para áreas } \\
\text { dentro um edifício } \\
\text { que fornece } \\
\text { condições críticas } \\
\text { ou funções } \\
\text { essenciais como } \\
\text { saídas e áreas } \\
\text { públicas; } \\
\text { - Quando são } \\
\text { exigidos o uso de } \\
\text { materiais do grupo } \\
\text { 1e } 2 \text {, o uso da } \\
\text { madeira mesmo } \\
\text { com aplicação de } \\
\text { retardantes de } \\
\text { fogo não é } \\
\text { permitido. }\end{array}$ & \\
\hline
\end{tabular}

Fonte: da autora (2019) 
Quadro 4 - Requisitos de proteção ao fogo para sistemas construtivos em CLT

\begin{tabular}{|c|c|c|c|}
\hline \multicolumn{4}{|c|}{ Resumo dos requisitos de proteção ao fogo para sistemas construtivos em CLT } \\
\hline Austrália & Reino Unido & USA & Brasil \\
\hline $\begin{array}{l}\text { National Construction } \\
\text { Code (NCC) }\end{array}$ & $\begin{array}{c}\text { The Building Regulation } \\
2010\end{array}$ & $\begin{array}{c}\text { International Build Code } \\
\text { (IBC) }\end{array}$ & $\begin{array}{l}\text { ABNT NBR } \\
15575: 2013\end{array}$ \\
\hline $\begin{array}{l}\text { Embora o projeto de } \\
\text { estruturas maciças de } \\
\text { madeira seja } \\
\text { abordado nas } \\
\text { respectivas normas de } \\
\text { madeira da Austrália } \\
\text { não é feita uma } \\
\text { menção espećíica ao } \\
\text { design e detalhamento } \\
\text { do CLT. No entanto, } \\
\text { os produtos de } \\
\text { madeira não } \\
\text { especificados no } \\
\text { código de obras } \\
\text { australiano, ainda } \\
\text { podem ser usados se } \\
\text { as suas propriedades } \\
\text { forem estabelecidas } \\
\text { por ensaios e } \\
\text { avaliação. }\end{array}$ & $\begin{array}{l}\text { Não tem referência sobre } \\
\text { o CLT no código } \\
\text { britânico, porém não há } \\
\text { material construtivo } \\
\text { restrito desde que seja } \\
\text { cumprido o requisito do } \\
\text { regulamento. O uso de } \\
\text { Normas Britânicas } \\
\text { apropriadas e / ou } \\
\text { Normas Europeias. Por } \\
\text { exemplo, em relação aos } \\
\text { materiais combustíveis, } \\
\text { como a madeira, para ter } \\
\text { o controle de propagação } \\
\text { do fogo no interior da } \\
\text { edificação, a taxa de } \\
\text { liberação de calor e a } \\
\text { taxa de crescimento do } \\
\text { fogo devem atender a } \\
\text { classificação conforme os } \\
\text { ensaios BS 476-6 (BSI, } \\
\text { 1989) e BS 476-7 (BSI, } \\
\text { 1997), respectivamente. }\end{array}$ & $\begin{array}{l}\text { O CLT no IBC está na } \\
\text { classificação tipo IV } \\
\text { (Heavy Timber, HT) as } \\
\text { paredes externas devem } \\
\text { ter espessura não inferior a } \\
152 \text { mm e madeira tratada } \\
\text { com retardante de fogo } \\
\text { (FRTW) ou protegida com } \\
\text { chapas de gesso com } \\
\text { espessura mínima de } 12.7 \\
\text { mm ou outro material } \\
\text { incombustível. Elementos } \\
\text { de construção interior sem } \\
\text { espaços ocultos. Os } \\
\text { elementos que suportam } \\
\text { as cargas da laje devem } \\
\text { ter uma dimensão nominal } \\
\text { mínima de } 152,4 \text { mm } x \\
\text { 203,2 mm e } 203,2 \text { mm x } \\
\text { 203,2 mm, se suportarem } \\
\text { as cargas de piso. As vigas } \\
\text { do piso devem ter uma } \\
\text { dimensão nominal mínima } \\
\text { de } 152,4 \text { mm } x 254 \text { mm, e } \\
\text { vigas da laje devem ter } \\
\text { uma dimensão nominal } \\
\text { mínima de } 101,6 \text { mm x } \\
152,4 \text { mm. O piso deve ter } \\
\text { uma espessura nominal } \\
\text { madeira laminada cruzada } \\
\text { (CLT) de } 101,6 \text { mm de } \\
\text { espessura. As coberturas } \\
\text { em CLT de } 76,2 \text { mm de } \\
\text { espessura. As paredes de } \\
\text { compartimentação devem } \\
\text { ser de } 60 \text { min. de } \\
\text { construção com resistência } \\
\text { ao fogo e painel de CLT } \\
\text { mínimo de } 101,6 \text { mm de } \\
\text { espessura. }\end{array}$ & $\begin{array}{l}\text { A norma especifica } \\
\text { para projeto } \\
\text { estrutural de } \\
\text { madeira em } \\
\text { situação de } \\
\text { incêndio aplica-se } \\
\text { o Eurocode 5, que } \\
\text { determina que o } \\
\text { projeto deve ser } \\
\text { feito pelo cálculo } \\
\text { da seção residual } \\
\text { transversal ou pelo } \\
\text { método alternativo } \\
\text { das propriedades } \\
\text { mecânicas } \\
\text { reduzidas. }\end{array}$ \\
\hline
\end{tabular}

Fonte: da autora (2019) 


\section{O SISTEMA CROSS LAMINATED TIMBER (CLT) E A SEGURANÇA CONTRA INCÊNDIO}

Desde o início deste século, estão sendo realizados ensaios em vários países da Europa, Estados Unidos e Canadá para caracterizar o comportamento ao fogo dos elementos e do sistema em CLT como um todo.

Ensaios de comportamento ao fogo têm demonstrado que mesmo após o fim do incêndio, a carbonização é contínua nas vigas de madeira, diminuindo a sua seção transversal, e essa só cessa se o suprimento de oxigênio for insuficiente para a combustão. Um estudo observou um aumento de temperatura durante a fase de decaimento do incêndio quando há um desprendimento de partes das lamelas carbonizadas das lamelas internas, expondo a madeira intacta à ação do fogo e levando a um segundo flashover. Mesmo se a carbonização cessar, as temperaturas podem aumentar no centro do elemento e/ou componente de madeira - o que pode levar à perda de resistência da estrutura (SAITO ET AL. 2007; MEDINA HEVIA, 2014; KINJO ET AL. 2014 APUD ABU E BUCHANAN, 2017). Isso ocorre quando:

a) há falha da linha de aderência entre as lamelas do CLT, causada pela temperatura elevada, que pode promover a delaminação e exposição súbita de madeira fria ou carvão, e / ou;

b) placas de proteção (geralmente de gesso) caem e deixam a superfície da madeira exposta, e / ou;

c) a área da superfície exposta é demasiadamente grande (BRANDON; ÖSTMAN, 2016).

Na Europa, o uso do sistema construtivo em CLT tem se tornado cada vez mais consolidado, pois a emissão de pareceres técnicos favoráveis avalizados por documentos como do European Technical Assessments (ETA), obtidos pelo proponente (fabricante) do sistema, tem contribuído para a maior segurança e confiança para o uso do sistema. As diretrizes que estabelecem a avaliação técnica e de desempenho são desenvolvidas pela European Assessment Document (EAD). 
A EAD 130005-00-0304 de março 2015 Solid Wood Slab Element to be Used as a Structural Element in Buildings, estabelece as diretrizes para avaliação técnica dos painéis de CLT. De acordo com este documento na avaliação da reação ao fogo os componentes e elementos de CLT devem ser classificados como D-s2, d0, onde:

- D - Flashover após 2 minutos com fonte de ignição de 100kW (critérios: ignição, propagação da chama, taxa de liberação de calor de acordo com ISO 11925-2:2010 e BS EN 13823:2010, com exceção do piso)

- $\quad$ s2 - taxa de desenvolvimento de fumaça - partículas dentro de 600s

- d0 - não há gotejamento de partículas flamejantes

O painel de CLT bruto para pisos (sem qualquer revestimento) é classificado como Dfl-s1 (material combustível com contribuição média ao fogo e sem ou fraca taxa de desenvolvimento de fumaça) de acordo com a BS EN 13501-1: 2018.

Para a avaliação da resistência ao fogo, a EAD 130005-00-0304 determina que o painel deve ser testado e classificado conforme a BS EN 13501-2:2010, e alternativamente a resistência pode ser calculada com base na EN 1995-1-2:2004. As taxas de carbonização devem ser indicadas com base em ensaios e a direção e o sentido das lamelas em relação à carga aplicada devem ser cuidadosamente observados.

A seguir, veremos como medidas de proteção passiva podem contribuir para maior segurança contra incêndio do sistema construtivo em CLT, a fim de diminuir a probabilidade do início e o desenvolvimento do fogo ou mesmo retardar estes fenômenos.

\subsection{Projeto estrutural}

Para o cálculo de resistência ao fogo das estruturas de madeira o principal parâmetro é a taxa de carbonização $(\beta)$ :como visto no capítulo três, esta taxa indica a redução da seção transversal dos elementos estruturais e a velocidade na qual a madeira é convertida em carão. 
O comportamento de carbonização do CLT é diferente da carbonização de painéis de madeira homogêneos devido à sua composição com camadas coladas e às juntas entre as lamelas que podem levar ao aumento da carbonização.

Para os painéis de CLT, o cálculo do projeto estrutural de incêndio é indicado pelo método da seção transversal residual após a carbonização.

A resistência e rigidez das paredes e pisos CLT são principalmente fornecidas pelas lamelas paralelas à direção da carga, porque as lamelas intermediárias dos painéis, em posição ortogonal em relação à carga aplicada, não contribuem para a resistência estrutural. Isso deve ser levado em consideração no projeto de incêndio para os painéis de pisos ou paredes de CLT (ABU; BUCHANAN, 2017).

A Figura 43 mostra o conceito do método de seção transversal eficaz para CLT, para a camada sem carga (Figura 43 a) e para a camada com carga (Figura 43b). Em geral, a linha da seção residual pode terminar de forma transversal ou longitudinal.

Figura 43 - Método da seção transversal para o CLT

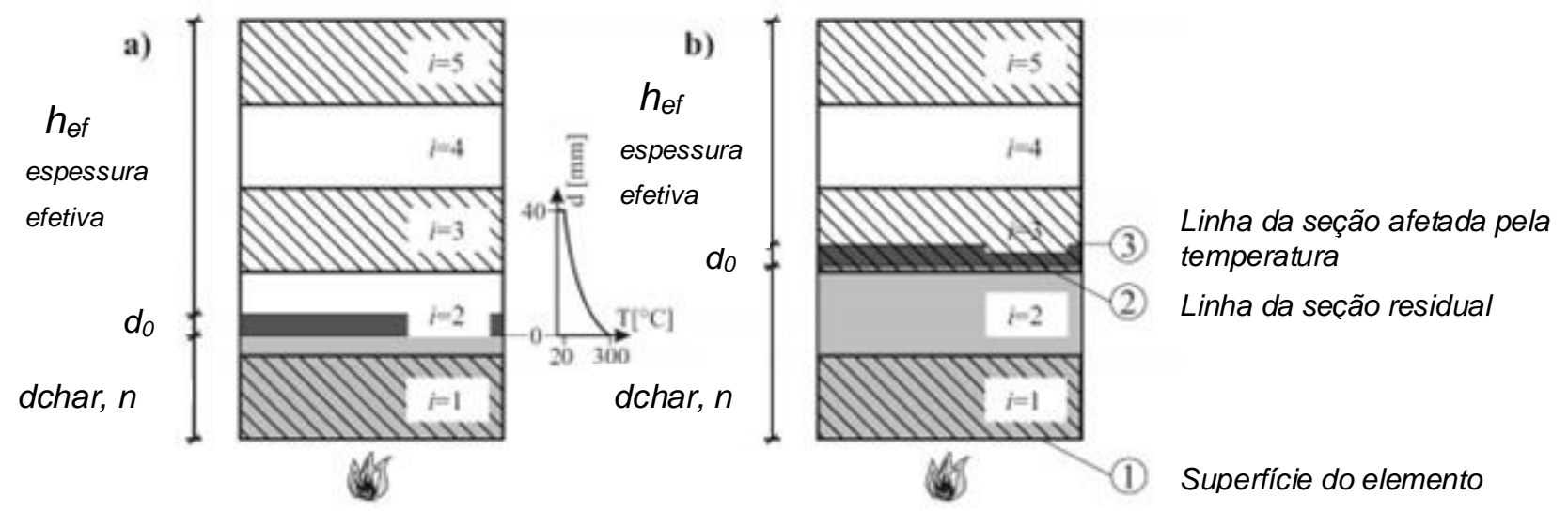

Fonte: Klippel, M, Just, A (eds) Guidance on Fire design of CLT including best practice, COST Action FP1404, Zürich, Switzerland, 2018.

A seção transversal do CLT é reduzida pela profundidade efetiva da carbonização e deve ser calculada conforme a seguinte equação:

Onde:

$$
d_{\text {ef }}=d_{\text {char }}+d_{0}
$$




$$
\begin{array}{ll}
d_{\text {ef }} & \text { profundidade efetiva de carbonização }(\mathrm{mm}) ; \\
d_{c h a r} & \text { profundidade de carbonização }(\mathrm{mm}) ; \\
\mathrm{d}_{0} & \text { camada sem resistência }(\mathrm{mm}) .
\end{array}
$$

Observou-se que as lamelas carbonizadas se desprendem dos painéis de CLT destinados a laje e pisos em alguns ensaios de fogo, mas o desprendimento é menos comum para paredes de CLT. No entanto, a mesma taxa de carbonização é recomendada para ambos, pisos e paredes, com base em muitos resultados de ensaios. Apesar da possibilidade de algumas lamelas carbonizadas se desprenderem, geralmente para pisos de CLT geralmente não é necessário fazer um cálculo para a resistência ao fogo, pois a espessura do piso para limitar cargas de deflexões e para controlar as vibrações sob gravidade normal, já fornecem um nível suficientemente alto de resistência ao fogo (FRANGl et al., 2009).

Entretanto, onde se exige paredes estruturais e estas estão desprotegidas, os elementos de CLT devem ser constituídos de cinco camadas para garantir a estabilidade em situação de incêndio (caso as lamelas externas de ambos os lados estiverem completamente carbonizadas, ainda existem três camadas de lamelas remanescentes sendo duas paralelas na direção da carga contribuindo para a resistência estrutural).

Se não houver risco de queda da camada carbonizada devido à falha na linha do adesivo, a seção transversal do painel de CLT deve ser considerada como uma única camada como segue a expressão:

\section{Onde:}

$$
t_{\text {prot }, i} \leq h_{i} / \beta_{n}
$$

tprot, i tempo de proteção

$h_{i} \quad$ espessura da camada protetora

$\beta_{\mathrm{n}} \quad$ taxa de carbonização nominal

Se houver risco de queda da camada carbonizada devido à falha na linha de aderência, cada lamela na seção transversal do CLT deve ser considerada como uma camada separada nos cálculos. 
A aderência entre as lamelas é um fator crítico para garantir a segurança do painel em situação de incêndio. Durante um incêndio, temperaturas elevadas avançam mais rapidamente do que a velocidade de carbonização, o que resulta na redução da força de aderência do adesivo antes do início da carbonização, à medida que a temperatura aumentar irá diminuir o módulo elasticidade do adesivo. Sabese que a resistência ao cisalhamento e a tensão à normal ao adesivo entre as lamelas se deterioram a temperaturas acima do ambiente, estudo indicam que esta diminuição da aderência estaria entre $70^{\circ} \mathrm{C}$ e $190^{\circ} \mathrm{C}$. A delaminação é a combinação da temperatura do adesivo, a redução da resistência da madeira em relação à redução da força no adesivo e as forças aplicadas à aderência (EMBERLEY, 2017). O comportamento do adesivo em temperaturas elevadas deve ser entendido para o dimensionamento correto do projeto dos painéis de CLT em relação à colagem das lamelas em condições ambientais e de temperatura elevada.

O uso da taxa de carbonização nominal $\beta$ n contribui para o aumento do fator de segurança para 0 projeto estrutural contra incêndios do CLT. A taxa de carbonização nominal $\beta \mathrm{n}$ pode ser determinada usando os coeficientes $\mathrm{k}$ (fator de modificação que leva em consideração o efeito da temperatura, podem ser vários fatores ex. $k_{n}$ - arredondamento de cantos, $k_{g}$ - espaços entre camadas, $k_{c o}$ coeficiente de conexão)(KLIPPEL e JUST, 2018).

No caso do CLT, se espaço entre duas lamelas não for maior que $2 \mathrm{~mm}$, a taxa unidimensional $\beta 0$ de carbonização para o projeto pode ser aplicado, significando que o coeficiente $\mathrm{kg}=1,0$. Caso o espaço esteja entre $2 \mathrm{~mm}$ e $6 \mathrm{~mm}$ a taxa unidimensional $\beta 0$ deve ser multiplicada por um coeficiente $\mathrm{k}_{\mathrm{g}}=1,2$ para determinar a taxa de carbonização nominal, se o espaço for maior que $6 \mathrm{~mm}$, deve ser considerada no cálculo a exposição ao fogo dos três lados.

Ensaios recentes de fogo (KLIPPEL et al.,2014; ÖSTMAN et al.,2010; SCHMID e KÖNIG 2010; SCHMID et al.,2010; GAGNON e PIRVU, 2011 apud ABU; BUCHANAN, 2017) sugerem que a taxa normal de carbonização de madeira maciça deve ser usada na primeira lamela, mas o dobro da taxa de carbonização deve ser usado para as lamelas sucessivas devido ao pré-aquecimento da próxima lamela. Esse método de projeto é recomendado, mas se alguma das lamelas internas tem 
espessura maior que $25 \mathrm{~mm}$, uma aproximação razoável é que a taxa de carbonização volte a velocidade inicial após esta espessura ter carbonizado.

Para uma resistência ao fogo de 30 minutos, não haverá influência da queda de lamelas carbonizadas quando a lamelas externa tem uma profundidade mínima de $25 \mathrm{~mm}$, pois somente a primeira camada será carbonizada. Para uma classificação de incêndio $\geq 60$ min., uma clara diferença na seção transversal residual é esperada, pois a lamela carbonizada pode sofrer queda e a lamela exposta estará sujeita a velocidade de carbonização maior (2x), replicando para outras lamelas e diminuindo a seção transversal do elemento e consequentemente a perda de resistência .

\section{Painéis com proteção}

O início da carbonização dos elementos de madeira pode ser prolongado usando revestimentos de proteção. O tempo de início da carbonização é determinada usando a soma dos tempos de proteção das camadas de revestimento $\left(t_{c h}=\sum\right.$ tprot $)$ de acordo com o método de adição de componentes. Considerando que se inicie a carbonização atrás o revestimento de proteção antes que ocorra sua falha, quando $t_{c h} \leq t \leq t_{f}$, as taxas básicas de carbonização $\beta_{\circ}$ do painel deve ser multiplicado por um fator de proteção. O coeficiente de proteção dado no EN 1995 1-2: 2004 é $K_{2}$ e ele é determinado pelas características físicas do material de revestimento como espessura e densidade. Por exemplo, o coeficiente de proteção de um elemento de madeira protegido por uma única camada de chapa de gesso para drywall tipo $F$ (com resistência ao fogo), é $K_{2}=1-0,018 h_{p}$, onde $h_{p}$ é a espessura da camada, em milímetros (EUROCODE 5, 2004).

Revestimentos ou sistemas de revestimento com classificação para incêndio é caracterizado pela capacidade de permanecer o maior tempo possível até o momento do seu desprendimento que pode ser denominado como tempo de falha $\left(t_{f}\right)$. O tempo de falha depende da espessura do revestimento utilizado e pode ser determinado de acordo com o método de ensaio EN 13381-7: Test methods for determining the contribution to the fire resistance of structural members applied protection to timber members (EUROCODE 5, 2004). 
O cálculo para o tempo máximo de proteção (tprot,max) inclui o tempo de proteção básica da camada protetora (tprot,0,i) e o coeficiente de proteção $\left(k_{2}\right)$ do sistema de revestimento ou revestimento classificado para fogo, conforme a seguinte equação:

Onde:

$$
t_{\text {prot } \max , \mathrm{i}}=\mathrm{t}_{\mathrm{pro}, 0, \mathrm{i}} / \mathrm{K}_{2}
$$

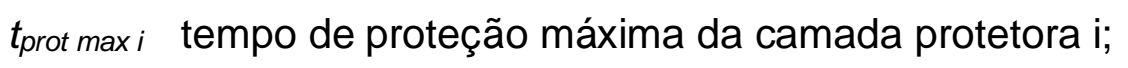

$t_{\text {prot, }, i} \quad$ tempo de proteção básica da camada protetora i;

$K_{2} \quad$ coeficiente de proteção.

A norma britânica BS EN 16351:2015 - Timber structures - Cross laminated timber - Requirements determina que para a resistência ao fogo do painel devem ser consideradas a geometria (por exemplo, tamanhos das lamelas transversais) e a taxa de carbonização (de lamelas), avaliada com base nas espécies utilizadas, pela densidade característica, classe de resistência da camada de madeira ou classe técnica.

A BS EN 16351:2015 também determina que para a reação ao fogo, as lamelas do painel de CLT devem ser avaliadas de acordo com a BS EN 14081-1: 2016 + A1:2019 e a reação ao fogo do painel de acordo com BS EN 13986:2004 + $A 1: 2015$. A madeira laminada cruzada deve ser ensaiada e classificada de acordo com a BS EN 13501-1: 2015 e as normas correspondentes às classes de reação ao fogo.

\subsection{Tratamentos retardadores de fogo}

A impregnação por produtos químicos retardadores de chama pode ter alguns efeitos negativos, incluindo a perda de resistência da madeira e corrosão dos fixadores, exacerbada pela natureza higroscópica de muitos dos produtos químicos (LEVAN; WINANDY, 1990); (WINANDY, 1995 apud ABU; BUCHANAN, 2017). Produtos químicos retardadores de fogo não melhoram significativamente a resistência ao fogo dos elementos da madeira, porque mesmo que a madeira 
tratada não suporte a combustão, continuará a carbonizar se exposta às temperaturas altas e ao fluxo de calor de um incêndio totalmente desenvolvido.

Ao usar retardadores de chama que podem atrasar a combustão de produtos de madeira derivados e reduzir a posterior liberação de energia, o comportamento ao fogo do CLT pode, dependendo do retardante utilizado, ser classificado como classe C (flashover após $10-100 \mathrm{~kW}$ ) ou B (sem flashover) (STORA, 2019).

O uso de tintas e vernizes aplicados manualmente é uma medida preventiva de proteção, porém a necessidade de reaplicação compromete a proteção ao longo do tempo.

Estudos realizados no Brasil com madeira tratada com retardantes de fogo demonstraram aumento na densidade da fumaça, mas com uma produção menor do total da fumaça devido à limitação da sua extensão pela ausência da propagação de chamas (AGUILAR, 1986).

\subsection{Conexões}

Todos os metais são condutores de calor muito melhores do que a madeira, então os fixadores de metal conduzirão o calor da superfície para o interior de qualquer conexão. As altas temperaturas no aço conduzem calor para a madeira, causando perda de rigidez ou carbonização, o que reduzirá a sua capacidade de carga.

Este princípio foi demonstrado em uma série de ensaios realizados por Leicester et al. (1979 apud ABU; BUCHANAN, 2017) para quatro tipos de conexões entre junções que foram submetidas à exposição ao fogo. Foi observado que os conectores com maior área de aço exposta ao fogo apresentaram um desempenho menor; altas temperaturas levam à carbonização ou perda de resistência da madeira em contato com o fixador. No entanto, conexões usando as chapas de aço terão uma resistência ao fogo muito melhor se as chapas forem embutidas nos elementos e/ou componentes de madeira expondo apenas uma borda, ao invés de estar do lado de fora, onde uma grande superfície de aço será exposta ao fogo em caso de incêndio. 
- Conexões desprotegidas

Existem vários tipos de conectores para madeira como pregos, parafusos, cavilhas, pinos, cantoneiras, chapas de aço etc. Os tipos mais comuns são parafusos sextavados e cavilhas, amplamente utilizados em conexões de madeira. Cavilhas são semelhantes aos parafusos sextavados, exceto que as cavilhas não têm capacidade axial, além disso é importante considerar a resistência e a rigidez da madeira da cavilha e a rigidez da interligação.

Para o CLT as conexões entre elementos podem ser de três tipos: conexões entre duas paredes ou duas lajes, entre lajes e paredes, entre paredes e fundações (OLIVEIRA, 2018 apud BRANDER et al., 2016). A fixação entre elementos de CLT lado a lado é feita geralmente por meio de parafusos e chapas de metal com quatro parafusos: para conexão entre paredes e lajes é comum também o uso de parafusos com inclinação de $45^{\circ}$ e cantoneiras.

O Eurocódigo 5 permite que as resistências ao fogo mínimas possam acrescer em $30 \mathrm{~min}$. se for aumentada a espessura ou largura dos membros laterais de madeira, ou as distâncias das extremidades e arestas para os fixadores.

\section{- Conexões protegidas}

Os fixadores de aço podem ter boa resistência ao fogo se estiverem suficientemente protegidos contra o fogo. A proteção pode ser obtida embutindo o fixador na seção de madeira, ou aplicando uma camada de material de revestimento tal como madeira maciça ou chapas de gesso. Para ligações protegidas, o Eurocódigo 5 fornece vários métodos para calcular a resistência ao fogo de conexões com vários tipos de fixadores e placas de aço internas, por tipo de proteção.

O British Standard e alguns códigos americanos exigem que qualquer conexão metálica seja protegida com madeira suficientemente para atender 0 critério da seção residual (BUCHANAN, 2017).

Ensaios mostraram que uma camada de placa de gesso pode ser usada para aumentar a resistência ao fogo de conexões de reforço de aço além daqueles dos 
elementos conectados. Tinta intumescente aplicada ao reforço da chapa de metal oferece apenas um pequeno aumento na resistência. Em outros ensaios obteve-se boa resistência ao fogo das conexões protegendo-as com a própria madeira laminada ou com madeira aglomerada e lã mineral (BUCHANAN; KING, 1991; CARLING, 1989; AARNIO; KALLIONIEMI, 1983 apud ABU; BUCHANAN, 2017).

\subsection{Adesivos}

Quando exposto ao fogo, os elementos de madeira colada geralmente se comportam da mesma forma que a madeira maciça, desde que adesivos estruturais aprovados sejam utilizados. Segundo Klippel (2014) todos os adesivos certificados de acordo com as atuais normas europeias mostram desempenho adequado ao fogo. Adesivos sensíveis a temperaturas elevadas, tais como adesivos elastoméricos, não devem ser utilizados sob a ação do fogo.

Painéis de CLT colados com adesivos estruturais aprovados têm demonstrado desempenho suficiente em ensaios de fogo para atender à maioria dos códigos de construção. No entanto é recomendado procurar informações técnicas junto aos fabricantes do CLT sobre o desempenho ao fogo de seus adesivos utilizados para ser especificado de maneira correta de acordo com a função e o uso da edificação.

Em relação ao adesivo também é muito importante considerar a capacidade da prensa para atender os requisitos de aderência entre as lamelas de 0,6 MPa. Neste sentido as prensas hidráulicas são as mais indicadas, pois conseguem aplicar cargas bem elevadas. Para os adesivos poliuretanos, ou a base de uréia formaldeído e resorcinol-formaldeido, as pressões recomendadas são, no mínimo de 0,9 Mpa (PEREIRA, 2015).

A BS EN 16351:2015 orienta que a avaliação do comportamento ao fogo do adesivo empregado deve estar conforme as normas BS EN 301:2017 e BS EN 15425: 2017.

Atualmente, o único fabricante nacional de painéis de CLT utiliza o adesivo estrutural monocomponente de poliuretano, sem solventes ou formaldeídos, do tipo Purbond da Henkel $A G^{\circledR}$. De acordo com o site do fabricante o adesivo é testado e 
aprovado de acordo com ASTM E119: 2019 e atende aos requisitos de ensaio de fogo para a qualificação de adesivo de temperatura elevada para madeira serrada (HENKEL, 2019).

No entanto, o ingrediente quimicamente reativo do adesivo poliuretano monocomponente é o diisocianato de difenilmetano (MDI). Este ingrediente pode liberar gases tóxicos em situação de incêndio, de acordo com a ficha do produto químico número ONU 2206, que se encontra no cadastro de licenciamento da Companhia Estadual de Tecnologia de Saneamento Básico e Controle de poluição das Águas (CETESB).

\subsection{Emenda das lamelas (Finger-joint)}

Nielsen e Olesen (1982) realizaram realizados ensaios com a madeira serrada em tensão axial em quatro temperaturas diferentes: $20^{\circ}, 90^{\circ}, 160^{\circ}$ e $230^{\circ} \mathrm{C}$ com e sem finger-joints. Os resultados indicam resistência para os dois grupos de material, exceto a $90^{\circ} \mathrm{C}$, onde o material é significativamente mais fraco do que o material não articulado. Os finger-joints são usados na maioria dos elementos de madeira laminada colada, a força de tensão longitudinal dos elementos e/ou componentes laminados depende da resistência do finger-joint, especialmente nas laminações externas.

Estudos experimentais e analíticos de vigas de madeira laminada coladas expostas ao fogo mostram que o método reduzido de seção transversal pode ser usado com segurança para o projeto de incêndio, e os efeitos do fogo no finger-joint podem ser ignorados, desde que os adesivos estruturais sejam aprovados de acordo com as normas EN atuais e os finger-joints estejam bem aderidos entre si (NIELSEN; OLESEN, 1982; KLIPPEL, 2014 apud ABU; BUCHANAN, 2017).

A BS EN 16351:2015 orienta que a avaliação do comportamento ao fogo da junção das lamelas no sentido longitudinal (finger joints) deve ser realizada com base na norma BS EN 14081-1: 2005 (última revisão BS EN 14081-1:2016+ A1:2019). 


\subsection{Junções}

A junção entre os elementos de CLT é muito importante para a resistência ao fogo, pois a ocorrência de cargas irregulares ou carbonização nas junções podem levar a diferentes desvios entre os elementos, resultando na falha da seção transversal residual.

As junções podem ser de encaixe macho e fêmea, tipo degraus, plana ou de canto entre os elementos de CLT. Entretanto irregularidades nos painéis de CLT resultantes da imprecisão da fabricação ou na execução da montagem podem permitir a passagem de chamas e gases quentes levando à carbonização.

Por meio de diversos ensaios concluiu-se que a segurança contra incêndio pode ser garantida se a seção transversal restante das junções for de pelo menos $2 \mathrm{~cm}$ (Figura $44 \mathrm{a}$ ).

Para evitar a passagem de gases quentes através das junções, fitas de vedação geralmente usadas para fins de estanqueidade ao ar, devem ser utilizadas. E alternativamente, um revestimento ou sistema de piso no lado não exposto também pode ser usado para evitar a penetração da fumaça pelo elemento.

Os ensaios de incêndio também apontaram que a profundidade de carbonização medida nos cantos era menor em comparação com os elementos de juntas planas (Figura 44 b), o que pode ser explicado pelo menor fluxo de calor nos cantos internos (KLIPPEL; JUST, 2018). 
Figura 44 - Comportamento da carbonização entre junções do painel a) junção tipo degrau e b) junção de canto

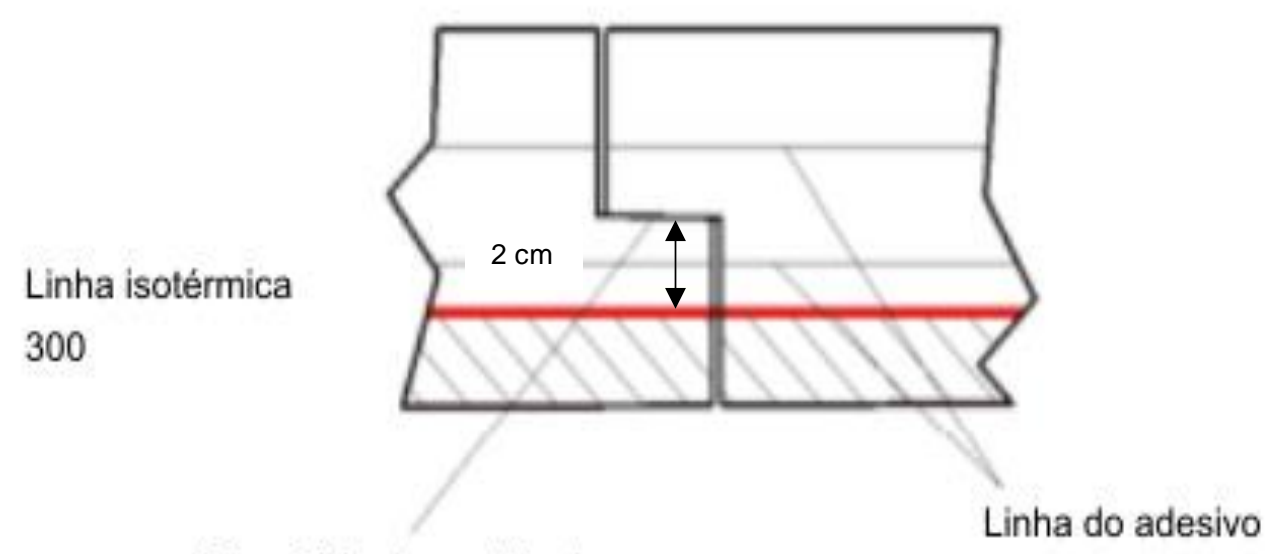

Superficie de contato das

a) junçōes

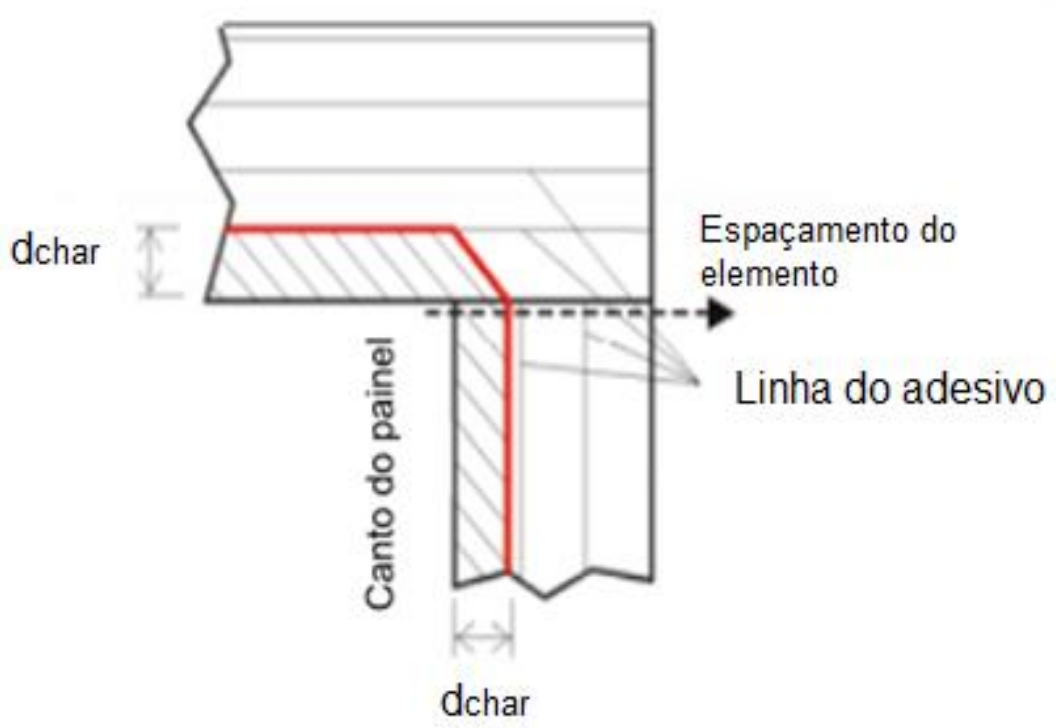

b)

Fonte: European Technical Assessment ETA - 06/138 (2017)

A avaliação da influência dos absorvedores de vibração de elastômeros na interface entre elementos de parede e piso é necessária para projeto de incêndio devido à combustibilidade do material. Ensaios de fogo com diferentes elastômeros absorvedores de vibração mostraram que não houve carbonização adicional entre as junções até 90 minutos e também não houve falha de integridade ou penetração de fumaça. Os resultados também apontaram que a profundidade de carbonização 
medida na lateral do elemento era menor em comparação com a face plana, o que pode ser explicado pelo menor fluxo de calor no local (WERTHER, 2016 apud KLIPPEL; JUST, 2018). Foi demonstrado que apesar de sua combustibilidade, esses absorvedores não reduzem a segurança contra incêndio quando aplicados em estruturas CLT se devidamente selados (Figura 45).

Figura 45 - Ensaio de fogo com elastômeros absorvedores de vibração na interface da parede e piso a) sem carbonização na lateral do elemento junto ao elastômero; b) sem carbonização do elastômero na junção entre piso e parede

a)

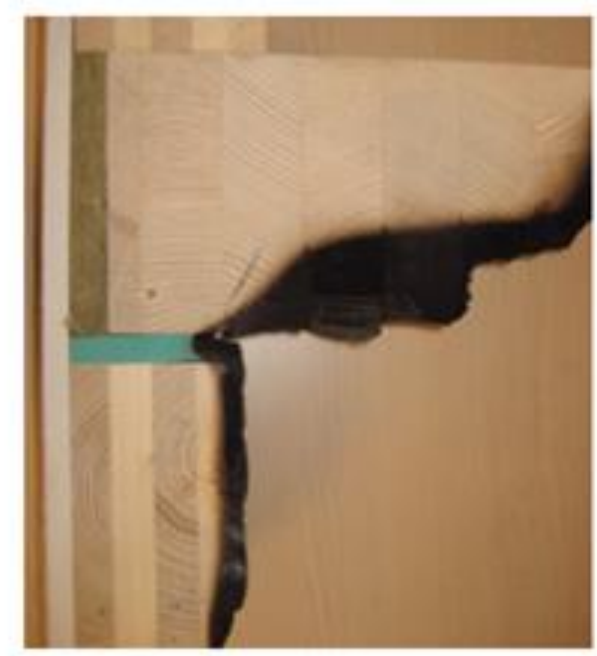

b)

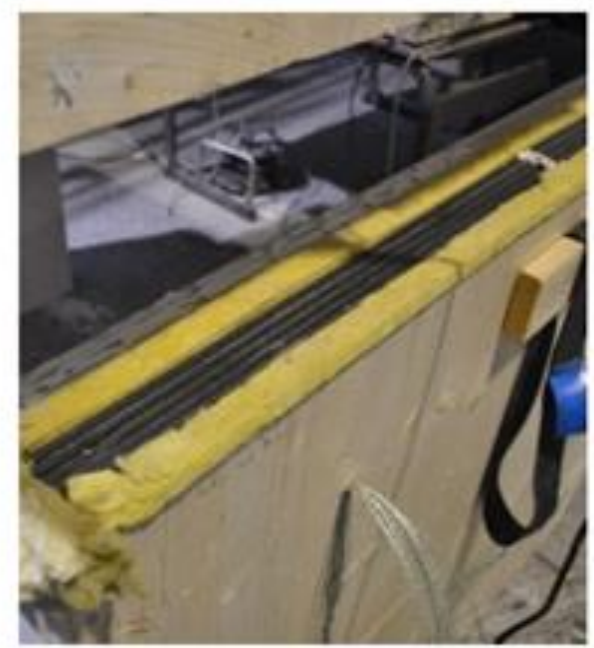

Fonte: Teibinger e Merk (2014)

Vistos os principais itens que devem ser levados em conta para o projeto estrutural para sistema CLT em situação de incêndio, segue um resumo no Quadro 5 a seguir: 
Quadro 5 - Resumo da proteção ao fogo para os elementos de CLT

\section{Requisitos e critérios}

\begin{tabular}{|c|c|c|}
\hline \multirow{2}{*}{$\begin{array}{l}\text { Resistência ao } \\
\text { Fogo }\end{array}$} & Sem Proteção & $\begin{array}{l}\text { Cálculo da sessão residual transversal. Resistência ao fogo } \\
\text { mínima de } 30 \text { min. (Figura 43; Equação } 4 \text { pag.29). }\end{array}$ \\
\hline & Com Proteção & $\begin{array}{l}\text { Resistência ao fogo do elemento com revestimento conforme } \\
\text { ensaios padronizados e resistência mínima } 60 \text { min. (Equação } 5 \\
\text { pag.30). }\end{array}$ \\
\hline \multirow{3}{*}{$\begin{array}{l}\text { Retardantes } \\
\text { de fogo }\end{array}$} & $\begin{array}{l}\text { Impregnação } \\
\text { por pressão }\end{array}$ & $\begin{array}{l}\text { Mais eficaz, porém pode ocorrer a diminuição da resistência e } \\
\text { corrosão dos fixadores metálicos. }\end{array}$ \\
\hline & $\begin{array}{l}\text { Pintura de } \\
\text { superfície }\end{array}$ & Superficial e necessidade de reaplicação. \\
\hline & Fumaça & $\begin{array}{l}\text { Aumento na densidade da fumaça, mas diminuição da produção } \\
\text { total (AGUILAR, 1986). }\end{array}$ \\
\hline \multirow[t]{2}{*}{$\begin{array}{c}\text { Taxa de } \\
\text { carbonização }\end{array}$} & Sem Proteção & $\begin{array}{l}\text { Principal parâmetro para o projeto de cálculo estrutural em } \\
\text { situação de incêndio, } 0,60-0,75 \mathrm{~mm} / \text { min para madeiras menos } \\
\text { densas e cerca de } 0,5 \mathrm{~mm} / \mathrm{min} \text { para madeiras densas (Eurocode } \\
\text { 5). Taxa de carbonização inicial decrescente com o } \\
\text { desenvolvimento do fogo, mas também pode aumentar } \\
\text { novamente se houver diminuição da espessura da seção } \\
\text { carbonizada. }\end{array}$ \\
\hline & Com Proteção & $\begin{array}{l}\text { A taxa de carbonização sob uma camada protetora é metade da } \\
\text { taxa de carbonização de madeira desprotegida, mas esta taxa } \\
\text { pode aumentar em até quatro vezes quando a proteção se } \\
\text { desprende, até atingir uma profundidade de } 25 \text { mm (EN } 1995 \text { 1-2: } \\
\text { 2004). }\end{array}$ \\
\hline \multirow[t]{2}{*}{ Conexões } & Sem Proteção & $\begin{array}{l}\text { Resistência ao fogo do elemento 15-20 min. Diâmetros mínimos } \\
\text { de } 2,8 \mathrm{~mm} \text { e } 45 \mathrm{~mm} \text { de espessura (EN } 1995 \text { 1-2:2004). Para } \\
\text { resistência de } 30 \text { min. aumentar a espessura dos } \\
\text { elementos/componentes e a distância das extremidades. } \\
\text { (pág.135). }\end{array}$ \\
\hline & Com Proteção & $\begin{array}{l}\text { Elementos com fixadores embutidos no painel ou revestidos com } \\
\text { madeira sólida ou chapas de gesso ou outro material com } \\
\text { resistência mínima de } 30 \text { min. (EN } 1995 \text { 1-2:2004) }\end{array}$ \\
\hline \multicolumn{2}{|c|}{ Adesivos } & $\begin{array}{l}\text { Estruturais, testados e aprovados de acordo com ASTM E119 e } \\
\text { atende aos requisitos de ensaio de fogo para a qualificação de } \\
\text { adesivo de temperatura elevada para madeira serrada. (ver BS } \\
\text { EN 301:2017 e BS EN 15425:2017). }\end{array}$ \\
\hline \multicolumn{2}{|c|}{$\begin{array}{l}\text { Finger-joints (Emendas das } \\
\text { lamelas) }\end{array}$} & $\begin{array}{l}\text { O efeito com temperaturas elevadas pode ser ignorado desde que } \\
\text { o adesivo usado seja certificado e resistente a altas temperaturas } \\
\text { e as emendas no painel sejam bem aderidas com espaçamento } \\
\text { ideal de } 0,2 \mathrm{~mm} \text {. (ver BS EN 14081-1:2016+ A1:2019). }\end{array}$ \\
\hline \multicolumn{2}{|c|}{$\begin{array}{l}\text { Junções (Emendas entre } \\
\text { elementos) }\end{array}$} & $\begin{array}{l}\text { Seção transversal restante das junções for de pelo menos } 20 \text { mm } \\
\text { e devidamente seladas. (ver Figura 44). }\end{array}$ \\
\hline
\end{tabular}

Fonte: da autora (2019)

Em resumo, os resultados das pesquisas mostraram que os painéis sem proteção têm grande probabilidade de contribuir para a taxa de crescimento, intensidade e duração do fogo, quanto maior for a área da superfície de madeira exposta. Mesmo assim, os resultados dos ensaios demonstraram que mesmo elementos de parede e piso sem proteção têm obtido uma resistência mínima de 30 
min. e que devido à falha da aderência das lamelas, pode ocorrer o desprendimento da superfície carbonizada, resultando em uma segunda ignição da nova camada exposta.

Por outro lado, o sistema de CLT com painéis protegidos por revestimentos resistentes ao fogo, em ensaios realizados em protótipos de escala real, mostrou resistência acima de 60 min. e não apresentou carbonização nos painéis logo abaixo do revestimento (SU e LOUGHEED,2014; SU e MURADORI, 2015 apudABU E BUCHANAN, 2017) .

Para o cálculo estrutural do CLT sob ação do fogo é recomendado o método da seção transversal residual após a carbonização segundo a norma EN 1995 1-2: 2004.

Durante um trabalho realizado pela COST Action FP1404 "Fire Safe Use of Bio-Based Building Products" (Segurança ao fogo da utilização de produtos de construção de base biológica), com o apoio da COST (Cooperação Europeia em Ciência e Tecnologia), foi demonstrado que alguns pareceres ETAs têm uma limitação significativa e podem ser considerados inconsistentes. O ideal é que a taxa de carbonização seja específica para cada produto de CLT devido às particularidades da fabricação (KLIPPEL; JUST, 2018).

No Brasil, até o momento do desenvolvimento desta pesquisa (dezembro de 2019), não havia nenhum resultado de ensaio padronizado divulgado que demonstre o desempenho ao fogo do painel de CLT fabricado no país.

5.7 Parâmetros da segurança contra incêndio para edifícios residenciais isolados, geminados e em unidades sobrepostas até dois pavimentos em CLT.

Como mencionado no capítulo anterior, no Estado de São Paulo edificações residenciais com área inferior a $750 \mathrm{~m} 2$ são isentas de quaisquer medidas de segurança contra incêndio para o Corpo de Bombeiros, mesmo no atualizado Decreto Estadual ํㅜ 63.911/2018.

No entanto, como já visto, as maiores incidências de incêndios ocorrem em edifícios residenciais e com a introdução de novos sistemas construtivos com 
materiais combustíveis como o CLT e Wood-framing, o potencial risco de incêndio poderá ser maior, além disso, a maioria dos sistemas construtivos introduzidos e já em produção carece de normas técnicas que podem dar suporte e orientação técnica aos projetistas e demais agentes na cadeia da construção civil.

Entretanto, a norma ABNT NBR 15575:2013 trata da questão da segurança contra incêndio para edificações habitacionais, independentemente de sua área construída.

A seguir, serão analisados os requisitos de segurança contra incêndio da ABNT NBR 15575:2013 citados no capítulo quatro na seção 4.2.5.3 especificamente para o sistema construtivo de CLT, a fim de se obter os parâmetros para unidades habitacionais isoladas, geminadas e unidades sobrepostas até dois pavimentos que utilizarão este sistema.

\subsubsection{Dificultar o princípio de incêndio}

O sistema construtivo de CLT, por ser constituído por material combustível tem potencial para atingir temperaturas suscetíveis ao princípio de incêndio. Portanto seus componentes e elementos devem ser montados, envolvidos ou separados por materiais resistentes à alta temperatura, como materiais não combustíveis, combustíveis com índice de inflamabilidade controlado, com baixa condutividade térmica ou tratados com retardantes de chamas para evitar a ignição. Além disso, é requerido o correto dimensionamento das instalações segundo as normas pertinentes a cada sistema.

A ABNT NBR 5410:2004 recomenda que as instalações elétricas nas edificações habitacionais classificadas como CA2, ou seja, construídas com materiais combustíveis, garantam que não vão provocar o início de incêndio em paredes, tetos e pisos.

Para a proteção contra descargas atmosféricas, devem-se seguir as disposições estabelecidas pela ABNT NBR 5419:2015, a fim de evitar princípios de incêndio e danos nas instalações elétricas e em materiais. 
Como exemplos de materiais que podem ser utilizados para impedir a passagem de fogo pelas instalações de serviço estão: concreto, fibra mineral de alta temperatura, fibra cerâmica de alta temperatura ou outro material que resista às temperaturas acima de $1120^{\circ} \mathrm{C}$ conforme o método de ensaio ISO 540:2008.

Para as instalações de recipientes abastecidos com GLP em ambientes enclausurados devem ser atendidos a ABNT NBR 15526:2012 e as outras disposições de acordo com a ABNT NBR 13523:2019.

\subsubsection{Dificultar a inflamação generalizada}

O sistema construtivo de CLT assim como seus elementos devem apresentar características de propagação de chamas controladas, assim como os materiais de revestimento, acabamento e isolamento termo acústico empregados na face interna destes. Os materiais de construção são classificados de acordo com a ABNT NBR 16626:2017. O método de ensaio para o elemento de piso de CLT é a ABNT NBR $8660: 2013$. Para o controle e classificação de materiais de acabamento e de revestimento devem ser realizados ensaios em condições que simulem as instalações reais. (ASSOCIAÇÃO NRASILEIRA DE NORMAS TËCNICAS, 2013 pg.17).

Painéis tratados contra o ataque de organismos xilófagos também devem ser ensaiados e atender às características de propagação de chamas para seu determinado uso e função conforme estabelecida na norma EN 15228:2009 Structural timber. Structural timber preservative treated against biological attack.

Finger joints também devem ser considerados na classificação de reação ao fogo nos elementos e componentes da madeira laminada cruzada, pois o comportamento de retração devido à temperatura na linha de cola pode permitir que a condução do calor leve a uma segunda ignição na lamela seguinte.

Para o correto dimensionamento e especificação das camadas que compõem os elementos do sistema construtivo de CLT, o sistema deve ser avaliado e classificado de acordo com métodos de ensaios nacionais específicos ou internacionais quando não há um método nacional correspondente. A ABNT NBR 
15575:2013 estabelece que os critérios a serem avaliados quanto a dificultar a inflamação generalizada são:

1. Reação ao fogo da face inferior do sistema de piso;

2. Reação ao fogo da face superior do sistema de piso;

3. Reação ao fogo da face interna do sistema de vedação vertical;

4. Reação ao fogo da face interna do sistema de cobertura das edificações;

5. Reação ao fogo da face externa do sistema de cobertura das edificações.

Por exemplo, a norma de desempenho estabelece que os materiais que compõem as camadas inferiores do sistema de piso (camada estrutural) devem ser avaliados e classificados conforme os métodos de ensaios ABNT NBR 9442:1986 e EN 13823:2010.

O elemento de CLT para parede com menor espessura para parede é de 57 $\mathrm{mm}$. Para materiais compostos por diversas camadas de materiais combustíveis com espessura superior a 25 mm, não se aplica o método ABNT NBR 9442:1986, sendo aplicável o método de ensaio EN 13823:2010.

Hipoteticamente, se o painel de CLT nacional for ensaiado e obtiver a mesma classificação D-s2, d0 dos painéis fabricados no exterior que corresponde a classe IV A no Brasil, com base no método de ensaio EN 13823:2010, esse painel sem proteção não poderá ser utilizado na cozinha onde se exige classe mínima III A ou em espaços comuns e espaços no interior de escadas enclausuradas que exige a classe mínima II A.

\subsubsection{Dificultar a propagação de incêndio}

As canaletas usinadas e perfurações para a instalação de serviços devem ser consideradas desde o início do processo de projeto para evitar a propagação de gases e chamas que possam comprometer a estabilidade estrutural.

Caminhos típicos de propagação de chamas resultantes de penetrações e junções são exemplificados na Figura 46. 
Figura 46 - Propagação de chamas entre as cavidades formadas pelas junções do sistema construtivo de CLT

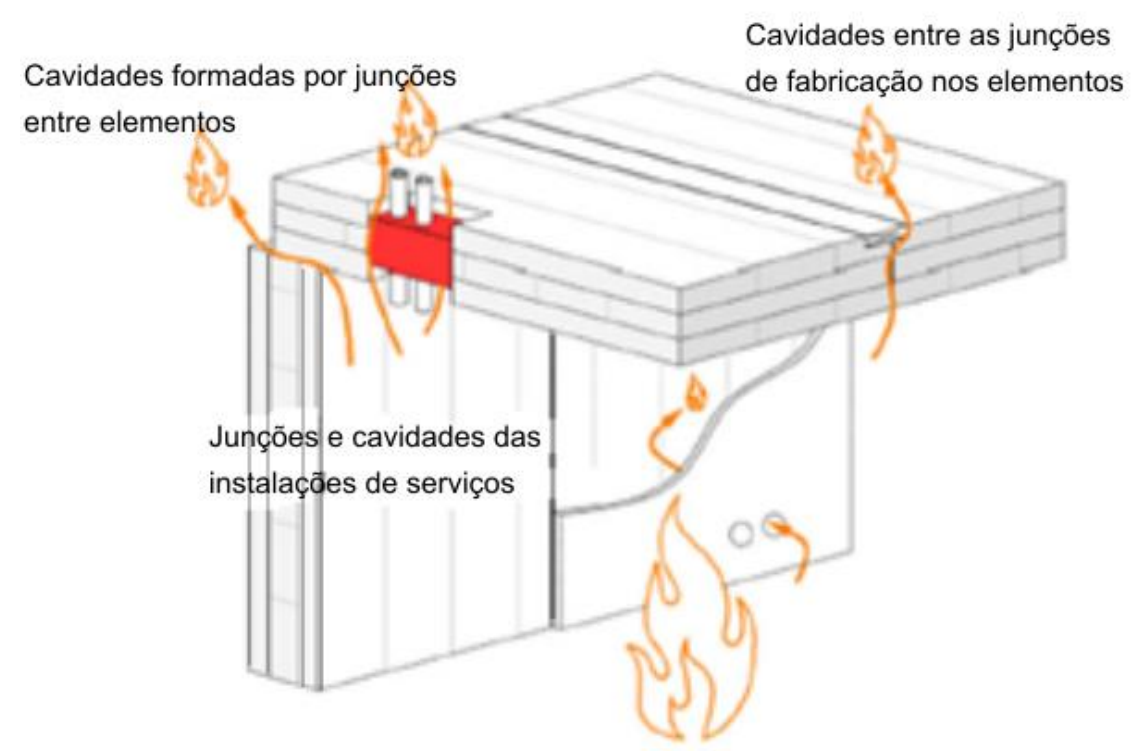

Fonte: Klippel e Just (2018)

Para evitar a propagação do fogo entre as interfaces dos elementos de CLT, as juntas contínuas, e as instalações devem ser seladas (com selantes, massas, colarinhos/anéis corta fogo etc.). Em alguns casos, inclusive na região de ralos, esse cuidado também deve ser tomado, a não ser que o forro tenha resistência ao fogo adequada (BRASIL, 2011).

A propagação das chamas para um edifício adjacente está associada à severidade do incêndio. Existem vários fatores que determinam a severidade de um incêndio como o tamanho, geometria, ventilação etc. do compartimento incendiado. Para o caso do CLT, sistema construtivo constituído de material combustível, a carga de incêndio tem significativa importância, porque qualquer grande área de madeira exposta contribuirá para a carga de incêndio no ambiente: isso também se aplica para superfícies de madeira não estruturais.

Para o uso residencial, de casas térreas ou assobradadas, a carga de incêndio específica é de $300 \mathrm{MJ}$ de acordo com a tabela do anexo A da Instrução Técnica N¹4: Carga de incêndio nas edificações e áreas de risco (CORPO DE BOMBEIROS DA POLÍCIA MILITAR DO ESTADO DE SÃO PAULO, 2018).

A carga de incêndio específica é o valor da carga de incêndio dividido pela área de piso do espaço considerado, expresso em megajoules (MJ) por metro 
quadrado $\left(\mathrm{m}^{2}\right)$. Método de cálculo determinístico para levantamento da carga de incêndio específica é dada pela seguinte equação:

$$
\mathrm{q}_{\mathrm{fi}}=\underline{\sum \mathrm{M}_{\mathrm{i}}} \underline{\mathrm{H}}_{A_{\mathrm{i}}} \quad \text { (Equação 7) }
$$

Onde:

qfi - valor da carga de incêndio específica, em megajoule por metro quadrado $\left(\mathrm{MJ} / \mathrm{m}^{2}\right)$ de área de piso considerado para o cálculo;

Mi - massa total de cada componente (i) do material combustível, em quilograma. Esse valor não pode ser excedido durante a vida útil da edificação exceto quando houver alteração de ocupação, ocasião em que (Mi) deve ser reavaliado;

$\mathrm{Hi}$ - potencial calorífico específico de cada componente do material combustível, em megajoule por quilograma.

Nota: IT N¹4 usa o Método de cálculo determinístico para a carga de incêndio específica para as edificações destinadas a explosivos e ocupações especiais.

Por exemplo, para o painel de CLT fabricado no Brasil com massa específica de $550 \mathrm{Kg} / \mathrm{m}^{2}$ e dimensões $3,00 \times 12,00 \mathrm{~m}$, a carga de incêndio específica pode ser calculada como:

$$
\begin{gathered}
q_{f i}=\frac{\sum M_{i} H i}{A_{f}} \\
q_{f i}=\frac{550.19}{36} \\
q_{f i}=290,77 \mathrm{MJ} / \mathrm{m}^{2}
\end{gathered}
$$

Nota: Considerar para o cálculo, potencial calorífico específico $\left(\mathrm{H}_{\mathrm{i}}\right)$ do material combustível, conforme Tabela C da IT -14: $1 \mathrm{~kg}$ (um quilograma) de madeira equivale a 19,0 megajoules (MJ).

Como indica o resultado da equação, se considerarmos todas as áreas expostas executados com painéis de CLT como paredes, piso, laje para um ambiente de $36 \mathrm{~m}^{2}$, a carga específica pode quadruplicar resultando aproximadamente em $1200 \mathrm{MJ} / \mathrm{m}^{2}$, somente considerando os painéis presentes neste ambiente. $O$ exemplo demonstra um aumento significativo das energias caloríficas que podem ser liberadas pela combustão completa dos elementos 
combustíveis contidos no espaço, ainda sem contar com a influência do revestimento das paredes, divisórias, pisos e tetos.

Além da severidade do incêndio, devem ser observadas as áreas de aberturas existentes e a resistência ao fogo do sistema composto pelas vedações verticais e horizontais.

Para o correto dimensionamento e especificação, os elementos que compõem os elementos do sistema construtivo de CLT devem ser avaliados e classificados de acordo com métodos de ensaios nacionais específicos ou internacionais correspondentes, quando não há um método nacional. A ABNT NBR 15575:2013 estabelece que os critérios a serem avaliados quanto a dificultar a propagação de incêndio são:

1. Reação ao fogo da face externa das paredes que compõem a fachada

2. Resistência ao fogo de elementos de compartimentação entre pavimentos e elementos estruturais associados

Após a avaliação e classificação dos elementos e sistemas, poderão ser especificados recursos para separar fisicamente edificações e/ou equipamentos. Os recursos podem ser áreas livres (distanciamento seguro), de barreiras de proteção, de anteparos e/ou paredes de material incombustível, com resistência mínima à exposição para dificultar a propagação de incêndio. Estes recursos vão assegurar a estabilidade, estanqueidade, o isolamento dos edifícios e suas partes.

A avaliação da reação ao fogo das faces externas das vedações verticais que compõem a fachada irá subsidiar o dimensionamento da distância mínima segura para o isolamento térmico e estanqueidade. Para o CLT o método de ensaio que se aplica é o EN 13823:2010, e devem ser atendidas em relação à fumaça: SMOGRA $\leq 30 \mathrm{~m}^{2} \mathrm{~s}^{2}$ e TSP $600 \mathrm{~s} \leq 50 \mathrm{~m}^{2}$.

A avaliação de resistência ao fogo irá determinar a espessura mínima do elemento ou da proteção necessária para obter a resistência mínima exigida do elemento de acordo com sua função e uso, assim como a distância mínima entre edifícios para evitar a propagação. Para habitações unifamiliares é exigido de TRRF de $30 \mathrm{~min}$. 


\subsubsection{Garantir a segurança estrutural em situação de incêndio}

Sistemas de paredes ou pisos resistentes ao fogo devem manter a capacidade de resistência ao fogo de todo o conjunto, considerando diferentes caminhos de transferência de calor. Isso deve ser assegurado no projeto, por exemplo, de detalhes de juntas entre lamelas, de juntas entre paredes e de juntas entre paredes e lajes.

O critério estabelecido na ABNT NBR 15.775:2013 de resistência ao fogo para paredes estruturais e de compartimentação para edifícios residenciais unifamiliares, isolados, até dois pavimentos e paredes de geminação (paredes entre unidades) de edifícios térreos ou sobrados geminados, assim como as paredes que fazem divisa com áreas comuns é de 30 min., no mínimo conforme a ABNT NBR 14432:2001 (BRASIL, 2011).

O método de avaliação deve ser feito pela análise do projeto estrutural em situação de incêndio ou ensaios de acordo com a norma em relação ao tipo de estrutura da edificação. Para sistemas construtivos de madeira a ABNT NBR 15575:2013 determina que a norma a seguir deve ser o Eurocode 5. A ABNT 5628:2001 indica dois métodos de ensaio, no caso do CLT o mais indicado seria a reaplicação do carregamemento após 24 horas após o término do aquecimento, pois mesmo após o término do ensaio, a carbonização é continua nos componentes e elementos de madeira, diminuindo a seção transversal, e essa só cessa se o suprimento de oxigênio for insuficiente para a combustão.

O Eurocode 5 estabelece que os elementos estruturais com resistência ao fogo que não excedam 60 minutos devem ser projetados para exposição ao fogo em ambos os lados e deve levar em consideração as contribuições de diferentes materiais na composição dos elementos e sua posição na montagem.

Também é indicada para o cálculo estrutural a análise dos elementos pósflashover, pois estes podem ser os responsáveis para que a estrutura entre em colapso.

Para a resistência ao fogo dos elementos de CLT, a EAD 130005-00-0304 determina que devem ser levados em conta a geometria, a espécie, densidade e 
classe técnica de resistência. O método de cálculo indicado é o da seção transversal reduzida, para todas as lamelas e com suas respectivas taxas de carbonização. Como visto no capítulo 3 , muitos códigos construtivos especificam uma taxa de carbonização constante no faixa $0,60-0,75 \mathrm{~mm} / \mathrm{min}$ para madeiras menos densas e cerca de 0,5 mm / min para madeiras densas (por exemplo, o Eurocode 5). Madeira laminada colada e madeira sólida são geralmente consideradas com a mesma taxa. Deve-se levar em conta que as taxas de carbonização são normalmente diferentes para:

a) superfícies desprotegidas durante o tempo de exposição ao fogo;

b) superfícies inicialmente protegidas antes da falha da proteção;

c) superfícies inicialmente protegidas quando expostas ao fogo após falha da proteção.

Em princípio, o aumento dos critérios para a resistência ao fogo pode ser compensado pelas seguintes medidas:

a) aumentar a espessura do elemento CLT;

b) aumentar o número de camadas do elemento CLT;

c) aumentar o revestimento correspondente.

Para o correto dimensionamento e especificação os sistemas que compõem os elementos do sistema construtivo de CLT devem ser avaliados e classificados de acordo com métodos de ensaios nacionais específicos ou internacionais quando não há um método nacional. A ABNT NBR 15575:2013 estabelece que os critérios a serem avaliados, quanto à segurança estrutural em situação de incêndio são:

1. Resistência ao fogo dos elementos de compartimentação entre pavimentos e elementos estruturais associados;

2. Resistência ao fogo dos elementos estruturais e de compartimentação vertical;

3. Resistência ao fogo do sistema de cobertura;

4. Selagem corta-fogo nas prumadas elétricas e hidráulicas;

5. Prumadas enclausuradas (shafts);

6. Escadas, elevadores, monta-cargas. 
5.7.4.1. Resistência ao fogo dos elementos de compartimentação horizontal (pisos) entre pavimentos e elementos associados

Os sistemas ou elementos de vedação entre pavimentos e elementos estruturais associados que integram os edifícios habitacionais devem atender aos critérios de resistência ao fogo de acordo com a ABNT NBR 14432:2001 para controlar os riscos de propagação do incêndio e preservar a estabilidade estrutural da edificação em situação de incêndio. A ABNT NBR 15575:2013 estabelece um critério mínimo de $30 \mathrm{~min}$. para os sistemas de entrepiso das unidades habitacionais isoladas, assobradadas ou geminadas. As Figuras 47 a 49 mostram exemplos de detalhes para a proteção ao fogo para os elementos de compartimentação entre pavimentos e elementos associados.

Figura 47 - Detalhe do painel de compartimentação entre pisos

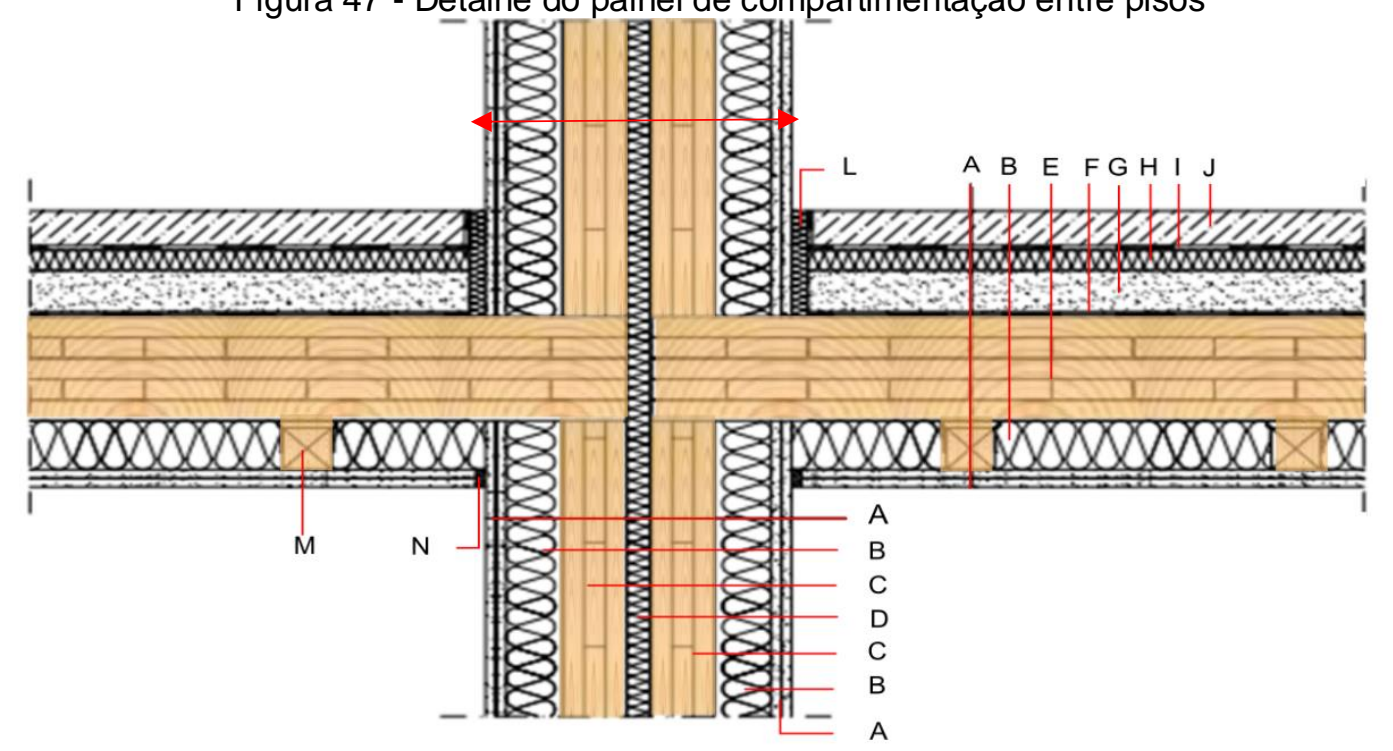

Fonte: Teibinger e Matzinger (2013) adaptado pela autora

Legenda:
A - $2 \times 12,5 \mathrm{~mm}$ Placa de gesso acartonado
B - Isolamento com lã de rocha
C - Painel de CLT 3 lamelas
D - Isolamento (ex. Iã de rocha, EPS, placa de gesso)
E - Painel de CLT 5 lamelas
F - Manta impermeável
$G$ - Preenchimento
$\mathrm{H}$ - Isolamento acústico
I - Manta impermeável
$\mathrm{J}$ - Contrapiso
$\mathrm{L}$ - Elastômero
M - Componente para fixação das placas de gesso
$\mathrm{N}$ - Fita de vedação 
Figura 48 - Detalhe do painel da fachada entre pisos

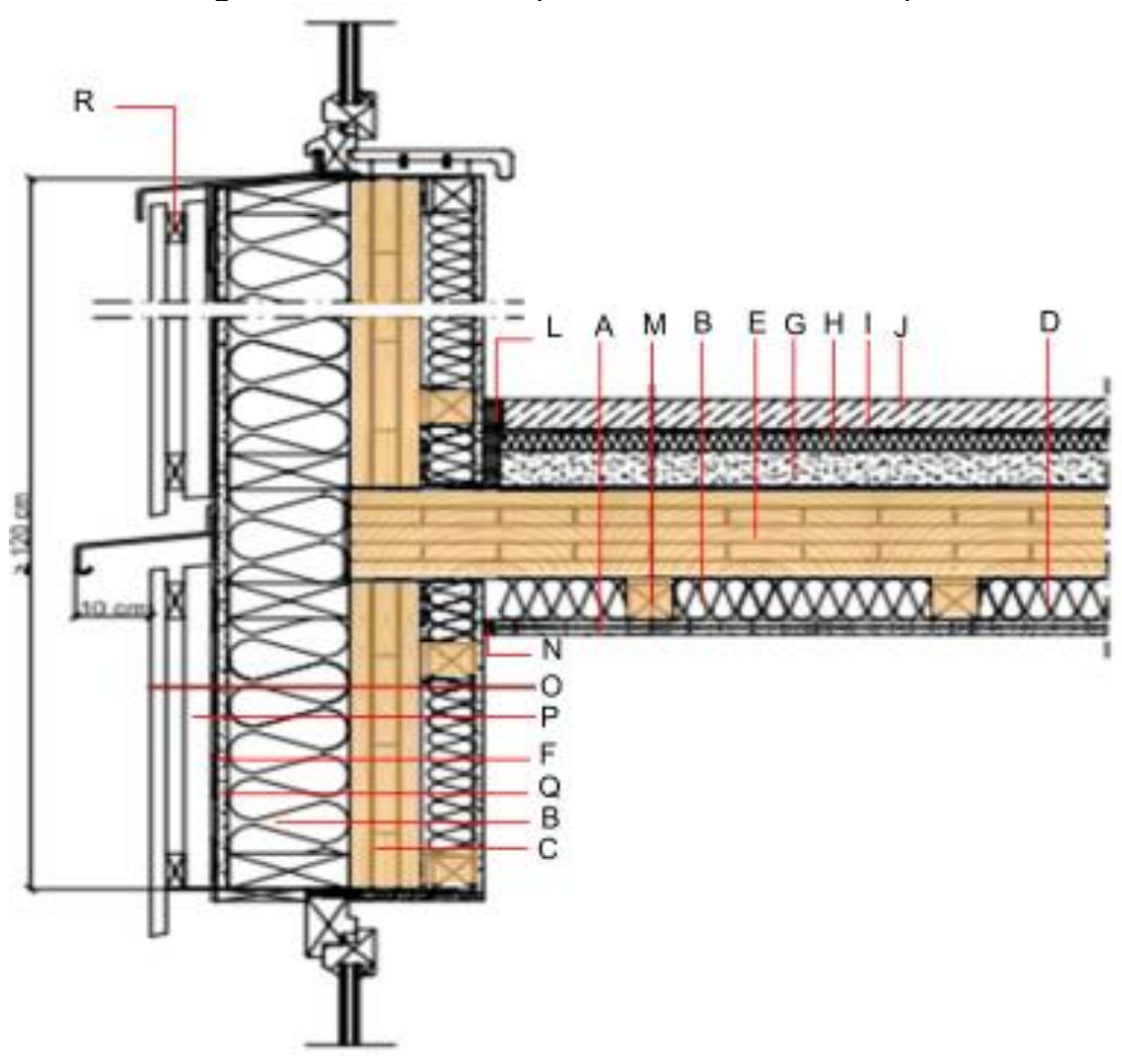

Fonte: Teibinger e Matzinger (2013) adaptado pela autora

Legenda:
A - $2 \times 12,5 \mathrm{~mm}$ Placa de gesso acartonado
B - Isolamento com lã de rocha
C - Painel de CLT 3 lamelas
D - Isolamento
E - Painel de CLT 5 lamelas
F - Manta impermeável
G - Preenchimento com argamassa cimentícia de revestimento
$\mathrm{H}$ - Isolamento acústico
I - Manta impermeável
J - Contrapiso
L - Elastômero
M - Componente para fixação das placas de gesso
$\mathrm{N}$ - Fita de vedação
O - Revestimento da fachada ventilada
$P$ - Revestimento secundário
Q - Placa compensada
$R$ - Componente de fixação do revestimento da fachada 
Figura 49 - Detalhe do painel de compartimentação para varandas

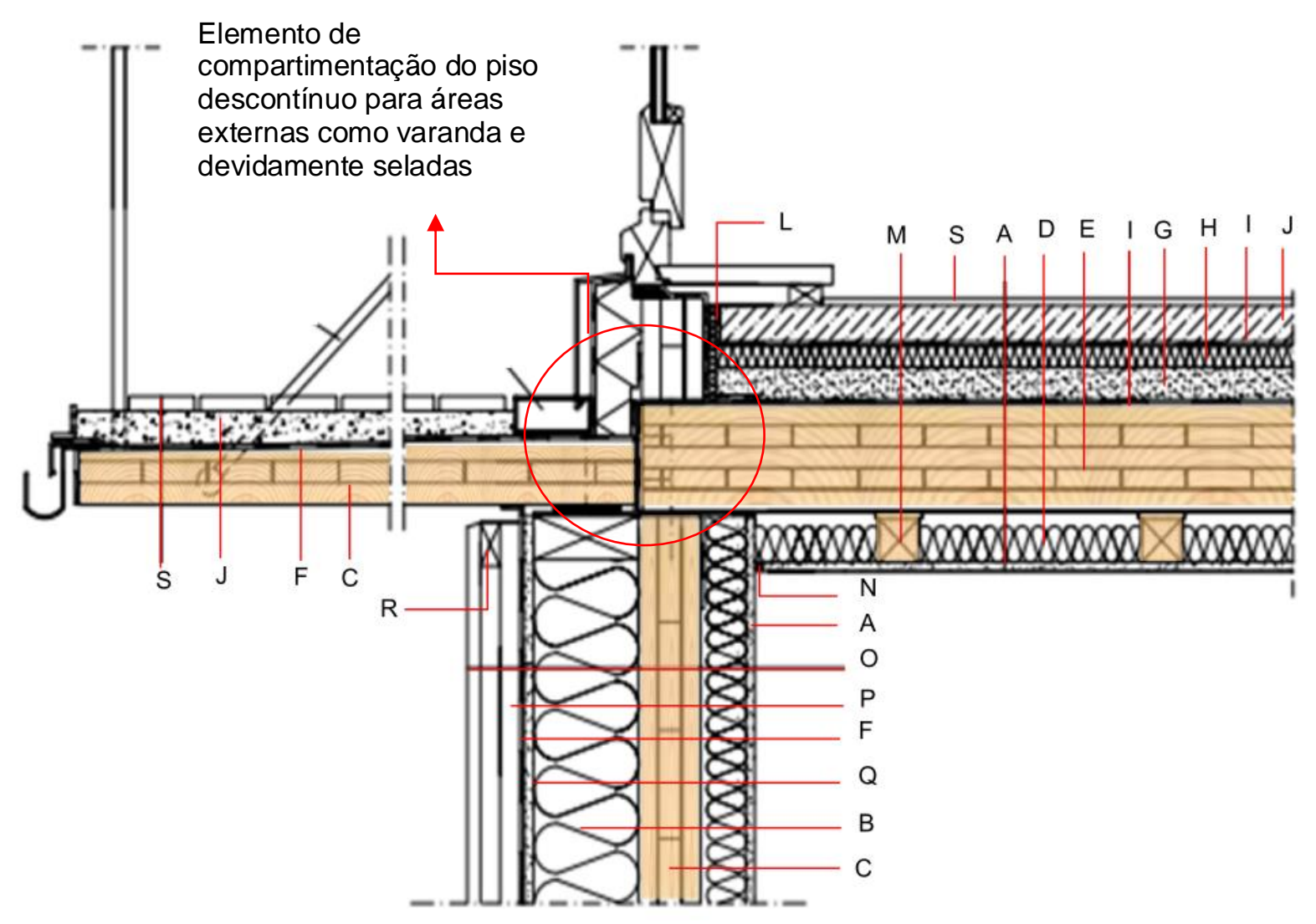

Fonte: Teibinger e Matzinger (2013) adaptado pela autora

Legenda:
A - $2 \times 12,5 \mathrm{~mm}$ Placa de gesso acartonado
B - Isolamento com lã de rocha
C - Painel de CLT 3 lamelas
D - Isolamento
E - Painel de CLT 5 lamelas
F - Manta impermeável
$\mathrm{G}$ - Preenchimento
H - Isolamento acústico
I - Manta impermeável
$\mathrm{J}$ - Contrapiso
$\mathrm{L}$ - Elastômero
M - Componente para fixação das placas de gesso
$\mathrm{N}$ - Fita de vedação
O - Revestimento da fachada ventilada
$P$ - Revestimento secundário
$\mathrm{Q}$ - Placa compensada
$R$ - Componente de fixação do revestimento da fachada

As figuras acima mostram exemplos de detalhes executivos para os elementos de compartimentação entre pavimentos e elementos associados, alguns itens como materiais de isolamento com lã de rocha são utilizados para proteção térmica (principalmente para países com clima frio), no entanto o uso desses 
materiais também podem contribuir e serem considerados como uma camada de proteção ao fogo a mais no sistema, nos próximos itens 5.7.4.2 e 5.7.4.3 veremos outras figuras com detalhes executivos que podem seguir a mesma recomendação.

5.7.4.2. Resistência ao fogo dos elementos estruturais de compartimentação vertical (SVVI)

Os sistemas ou elementos de vedação vertical internos que integram os edifícios habitacionais devem atender a ABNT NBR 14432:2001 para controlar os riscos de propagação do incêndio e preservar a estabilidade estrutural da edificação em situação de incêndio. A ABNT NBR 15575:2013 estabelece um critério mínimo de $30 \mathrm{~min}$. para os sistemas de compartimentação vertical e as camadas associadas para a proteção ao fogo a fim de garantir a estabilidade, estanqueidade e isolamento térmico das unidades habitacionais isoladas, assobradadas ou geminadas, como mostram exemplos de detalhes das Figuras 50 e 51 :

Figura 50 - Detalhe do elemento de compartimentação vertitcal

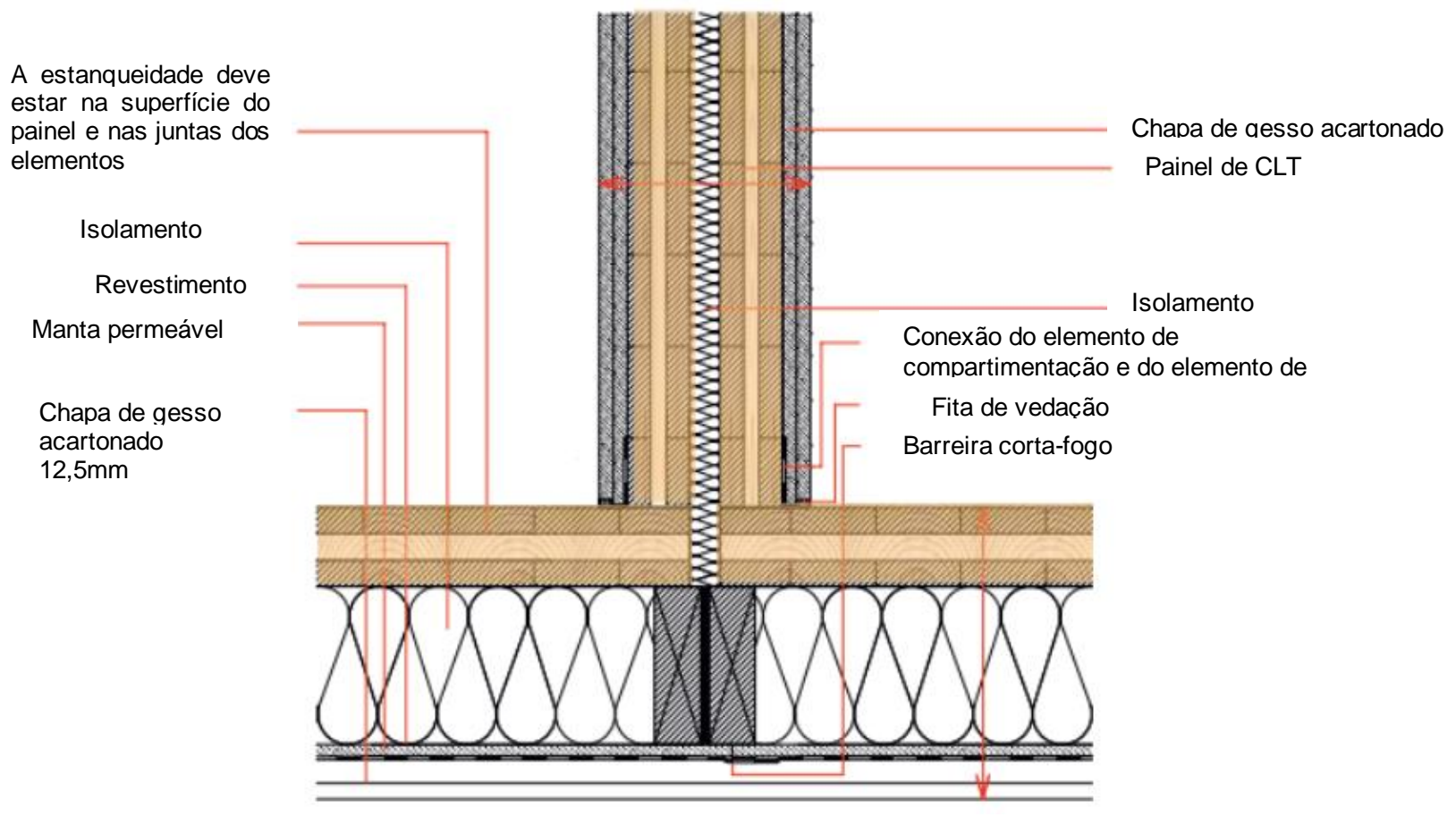

Fonte: Teibinger e Matzinger (2013) adaptado pela autora 
Figura 51 - Distâncias mínimas para a resistência do painel entre aberturas
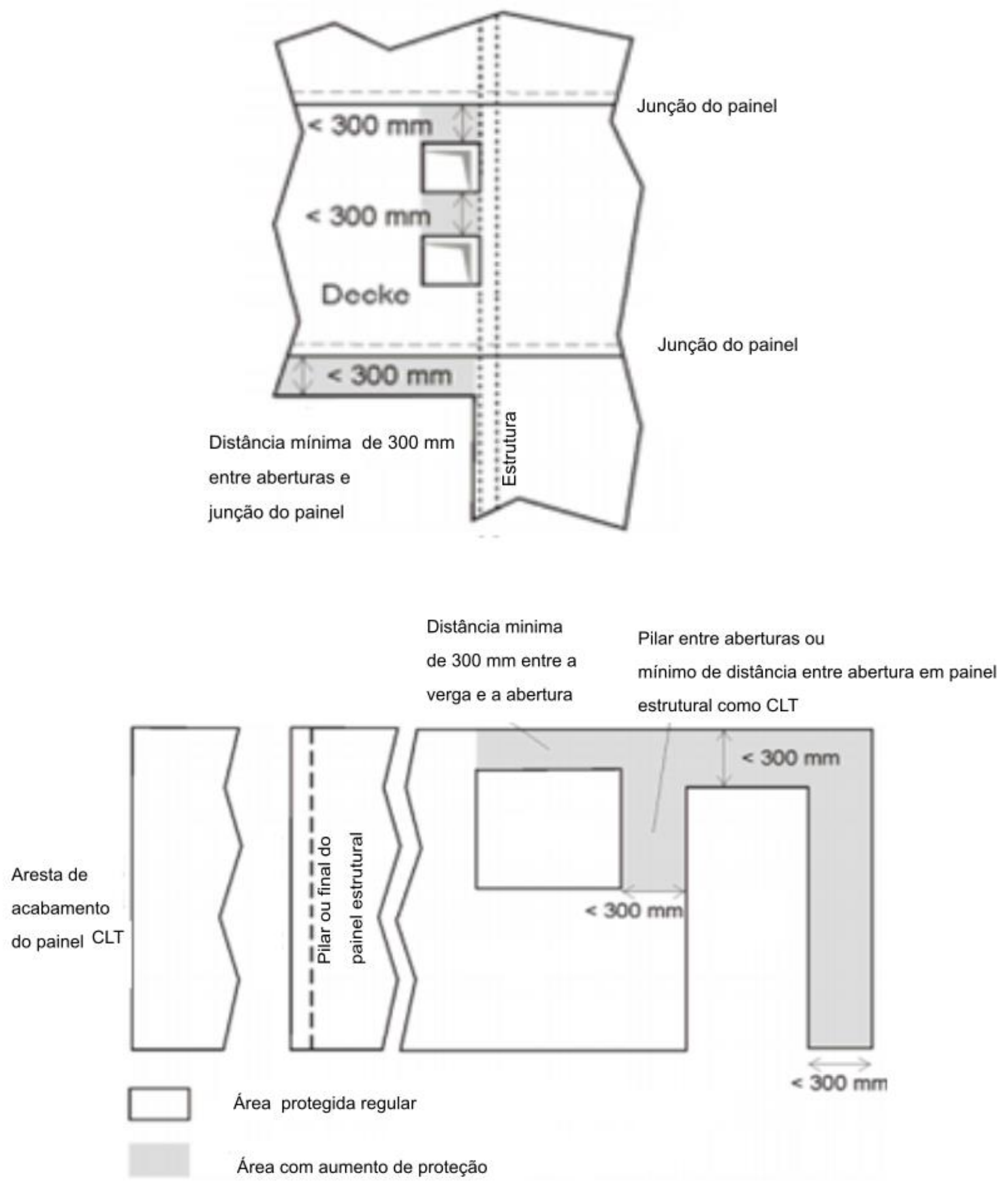

Fonte: European Technical Assentment - ETA - 06/138 (2017) tradução nossa 
Além das camadas associadas para proteção ao fogo e consequente aumento da resistência do elemento de compartimentação vertical deve ser levados em conta às dimensões mínimas e uma taxa de carbonização maior para o cálculo da resistência entre as aberturas nos elementos estruturais, conforme demonstrado na Figura 51.

\subsubsection{Resistência ao fogo do sistema de cobertura}

A resistência ao fogo do sistema de cobertura das unidades habitacionais isoladas, assobradadas ou geminadas, deve atender aos requisitos da ABNT NBR 14432:2001, considerando um valor mínimo de 30 minutos. Pode ser verificado na Figura 52 um exemplo de detalhes para execução da cobertura com a interface do sistema de revestimento externo.

Figura 52 - Detalhe da cobertura com isolamento

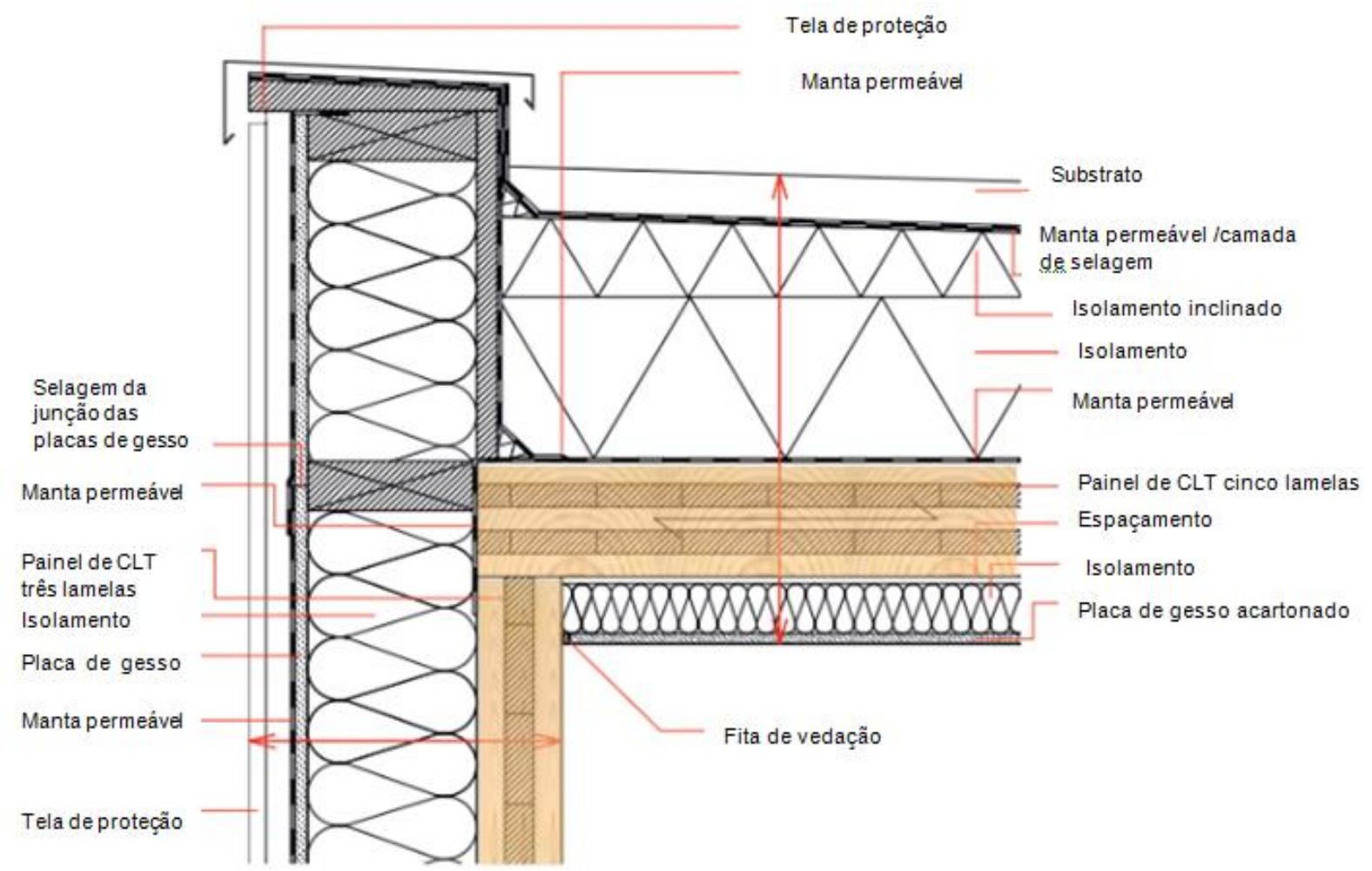

Fonte: Teibinger e Matzinger (2013) adaptado pela autora 


\subsubsection{Selagem corta-fogo nas prumadas elétricas e hidráulicas}

A usinagem de canaletas ou perfurações nos elementos com classificação de resistência ao fogo requerida devem ter a mesma resistência. Para garantir a segurança contra incêndio entre os elementos de CLT resistentes ao fogo devem ser evitadas juntas contínuas, e as instalações devem ser seladas com materiais intumescentes, massas, colarinhos/anéis corta fogo, etc., nos dois lados ou seguir continuamente no local usinado do elemento.

Sistemas com materiais intumescentes, ou seja, "sistemas ativos" que expandem quando exposto a altas temperaturas, podem selar com eficiência o espaço entre o elemento de madeira maciça, CLT e as juntas entre os dispositivos corta fogo. Para sistemas, sem capacidade de expansão sob a ação do fogo, ou seja, "sistema passivo", como massa de gesso, um selante adicional deve ser aplicado em ambos os lados do elemento para manter a estanqueidade (Figura 53).

Os sistemas de vedação devem ter camadas múltiplas, composta por materiais incombustíveis e isolantes como placas de lã mineral: o forro deve-se estender ao longo do elemento de compartimentação em combinação com um revestimento externo adicional não combustível emoldurado para cobrir as juntas e o revestimento também deve fornecer a mesma proteção do elemento estrutural (Figura 54).

Como alternativa a um revestimento emoldurado, soluções com tiras intumescentes ou revestimento intumescente na área de interface entre a laje e a parede podem ser usados para evitar a propagação do fogo. A mesma solução também pode ser usada para a instalação de portas, janelas ou amortecedores com classificação de incêndio.

Em relação aos tubos metálicos que passam nos elementos de madeira, o calor conduzido pelo tubo para o lado não exposto também deve ser considerado. Apesar de a vedação ser suficiente para evitar gases quentes na passagem, o calor conduzido pode inflamar elementos de madeira do lado não exposto, em contato direto com o tubo. Para evitar a condução de calor pelo tubo, guias orientativos europeus de segurança contra incêndio recomendam deixar um espaço mínimo de 
$15 \mathrm{~mm}$ em volta do tubo metálico e este deve ser calafetado e preenchido com lã mineral em combinação com um isolamento contínuo do tubo, com mostra a Figura 55 (TEIBINGER E MATZINGER, 2013).

Figura 53- Sistemas de material intumescente passivo e ativo

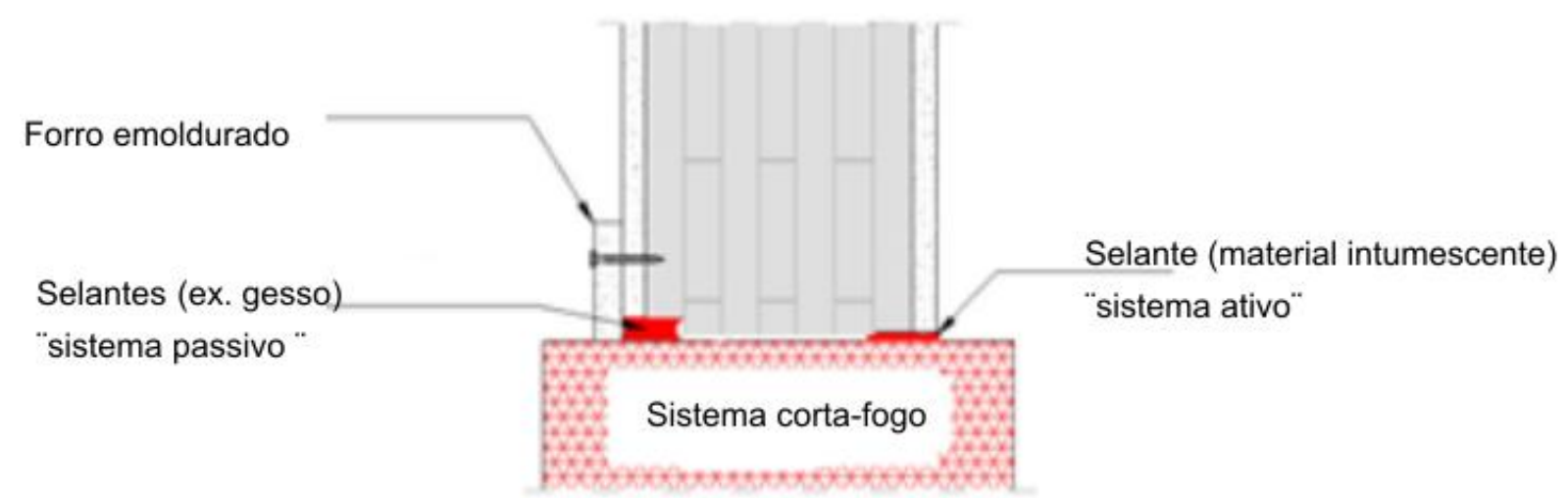

Fonte: Klippel e Just (2018)

Figura 54 - Revestimento de proteção ao fogo emoldurando a área para a passagem das instalações

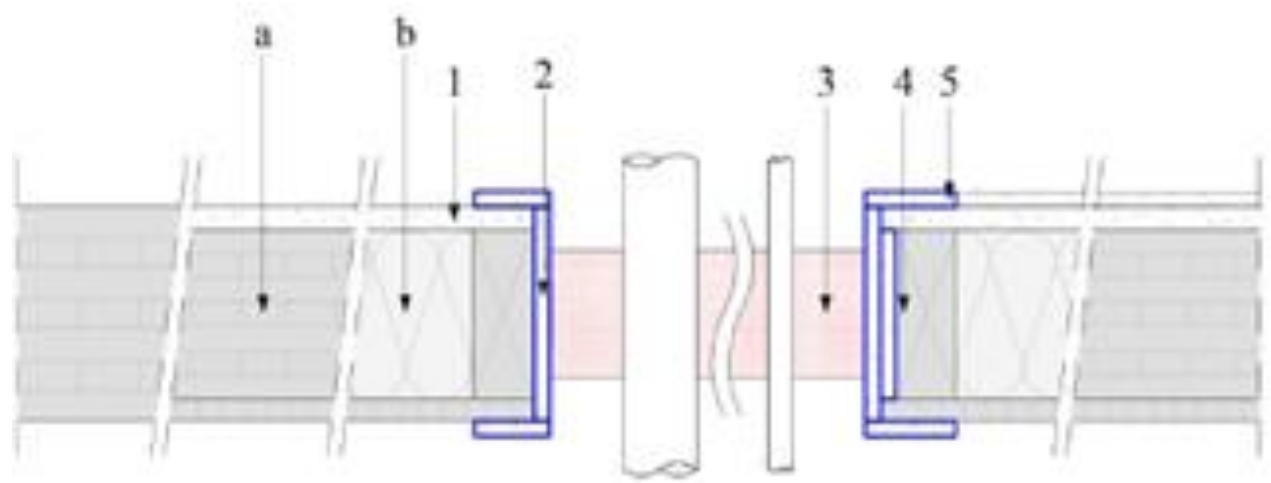

Fonte: Klippel e Just (2018)

Legenda:

1) forro;

2) revestimento não combustível na passagem das instalações;

3) perfuração da selagem;

4) componente de madeira;

5) moldura do forro mínimo $100 \mathrm{~mm}$;

a) componente de madeira estrutural (CLT);

b) isolamento 
Figura 55 - Selagem da tubulação metálica no elemento de CLT
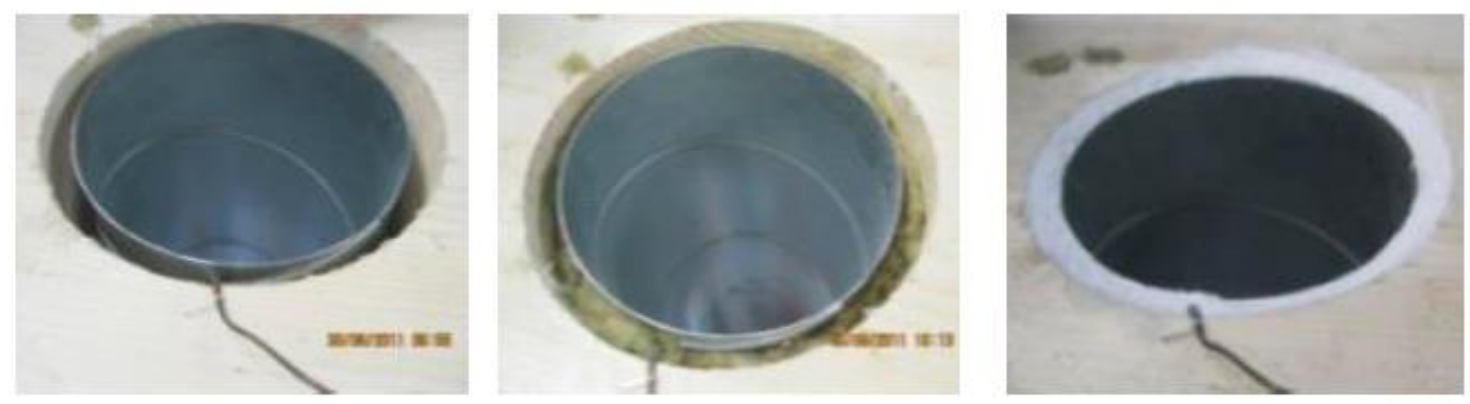

Fonte: Teibinger e Matzinger (2013)

Outra recomendação é que as instalações na laje com resistência ao fogo devem ser protegidas por um sistema ou dispositivo de contenção de fogo como, por exemplo, um amortecedor de radiação instalado no alinhamento da laje, onde as instalações penetram na laje com resistência ao fogo.

As passagens das instalações elétricas também devem ser consideradas desde o início do projeto no sistema construtivo de CLT para não diminuir o desempenho da segurança contra incêndio do sistema, pois pode ocorrer um aumento da carbonização na área das aberturas de tomadas e interruptores (Figura 56) entalhes atrás do revestimento também podem contribuir para a propagação do fogo no elemento.

Para a instalação de soquetes, interruptores e ligações correspondentes, podem ser usadas as seguintes soluções:

a) adição de uma camada protetora nos canais que reduzem a dimensão dos elementos estruturais, para a instalação dos componentes elétricos, Figura 57.

b) revestimento dos componentes elétricos instalados sob o elemento estrutural de CLT, com materiais de proteção (isolantes), Figura 58;

c) uso de soquetes com classificação de incêndio e revestidos com material resistente ao fogo;

d) passagens de cabos individuais em elementos resistentes ao fogo, onde os espaços vazios devem ser preenchidos com isolantes como por exemplo lã de rocha e calafetados com massa de gesso ou compostos intumescentes em toda espessura do elemento, Figuras 59 e 60; 
e) superdimensionamento do elemento CLT (KLIPPEL; JUST, 2018).

Figura 56 - Exemplos para as instalações elétrica embutidas no elemento de CLT
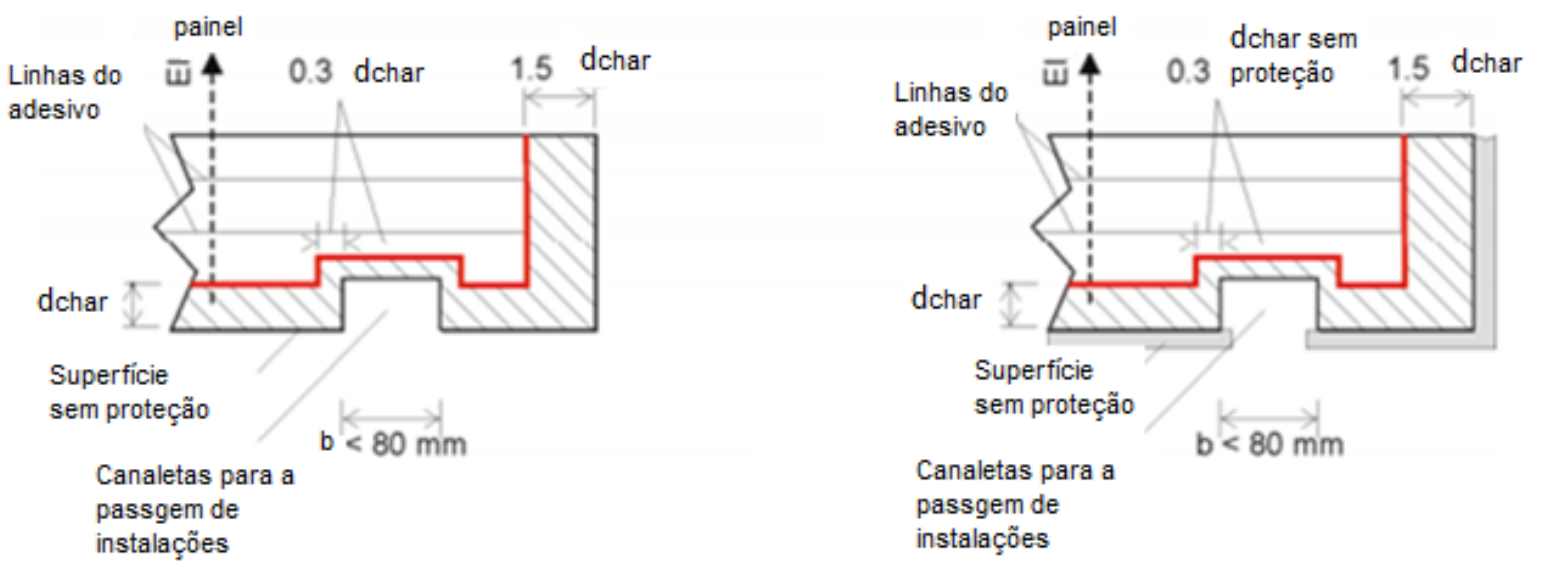

Fonte: European Technical Assessment ETA - 06/138 (2017)

Figura 57 - Aplicação de material intumescente para aumento da resistência ao fogo e carbonização do canal da passagem das instalações e da borda do painel

Vista

Corte

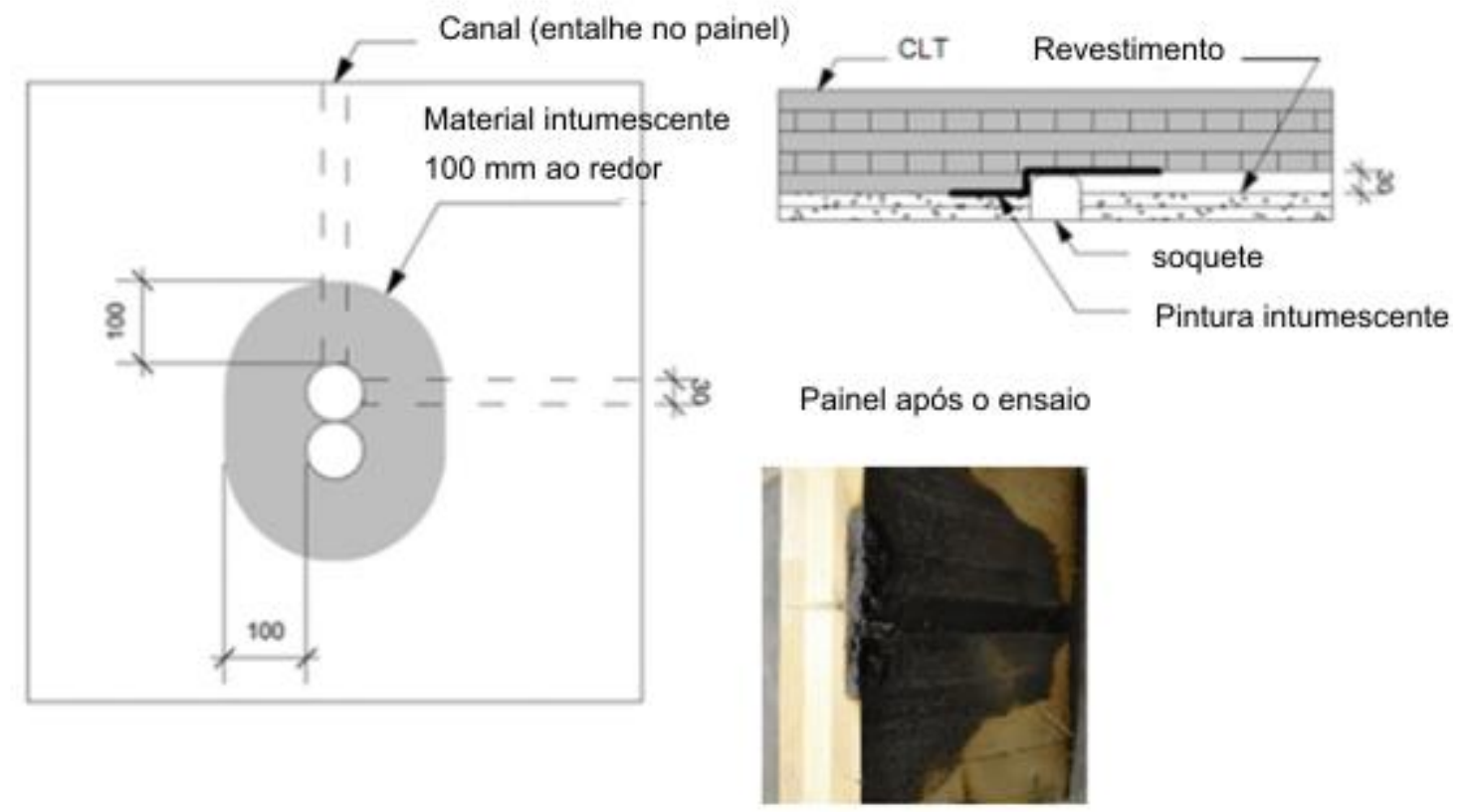

Fonte: Klippel e Just (2018) 
Figura 58 - Camada adicional para a instalação de tomadas e interruptores

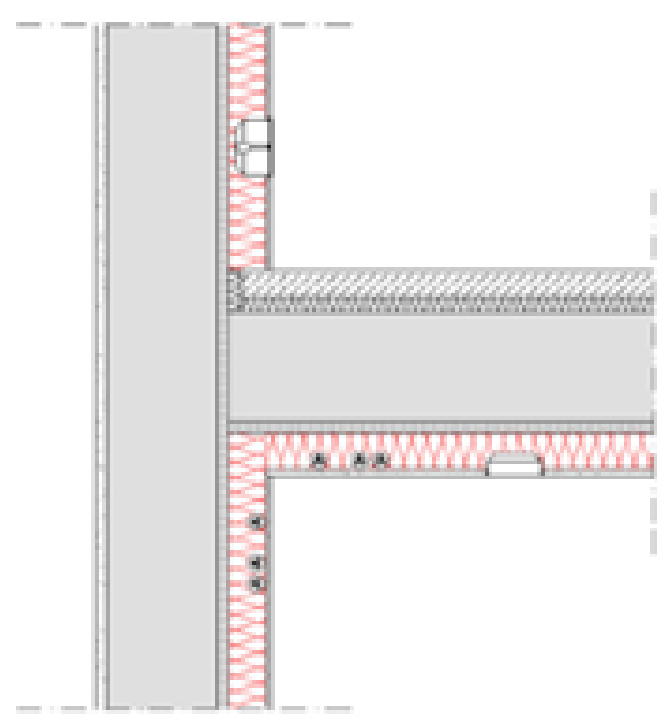

Fonte: Klippel e Just (2018)

Figura 59 - Revestimento do canal no painel para a passagem de instalações
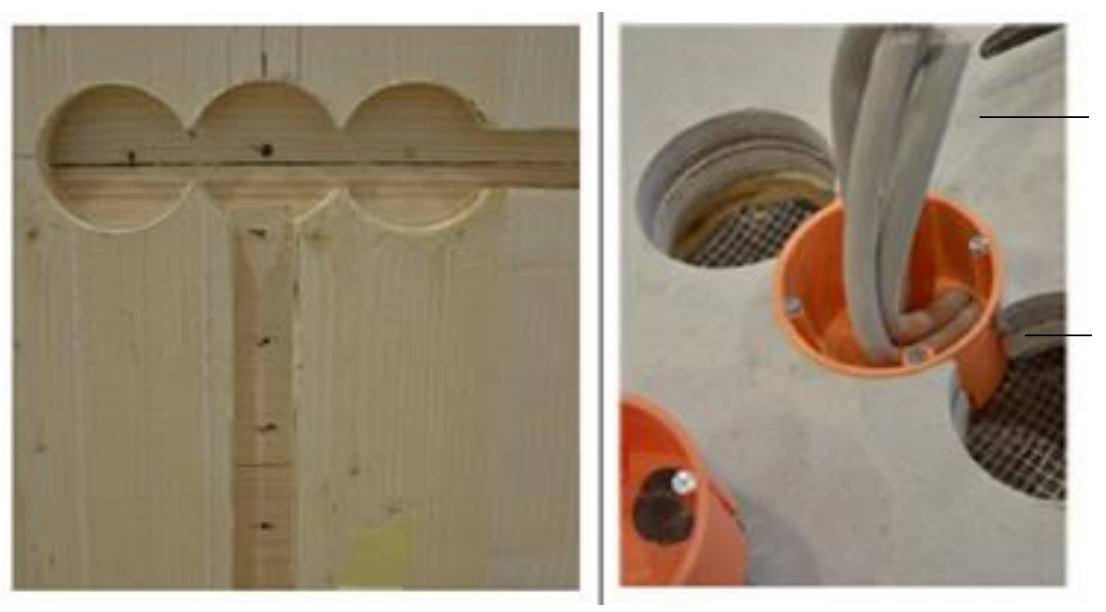

Placa cimentícia

Fonte: Klippel e Just (2018)

Figura 60 - Instalação elétrica revestida com material isolante como lã de rocha e calafetada com compostos intumescentes em toda espessura do elemento
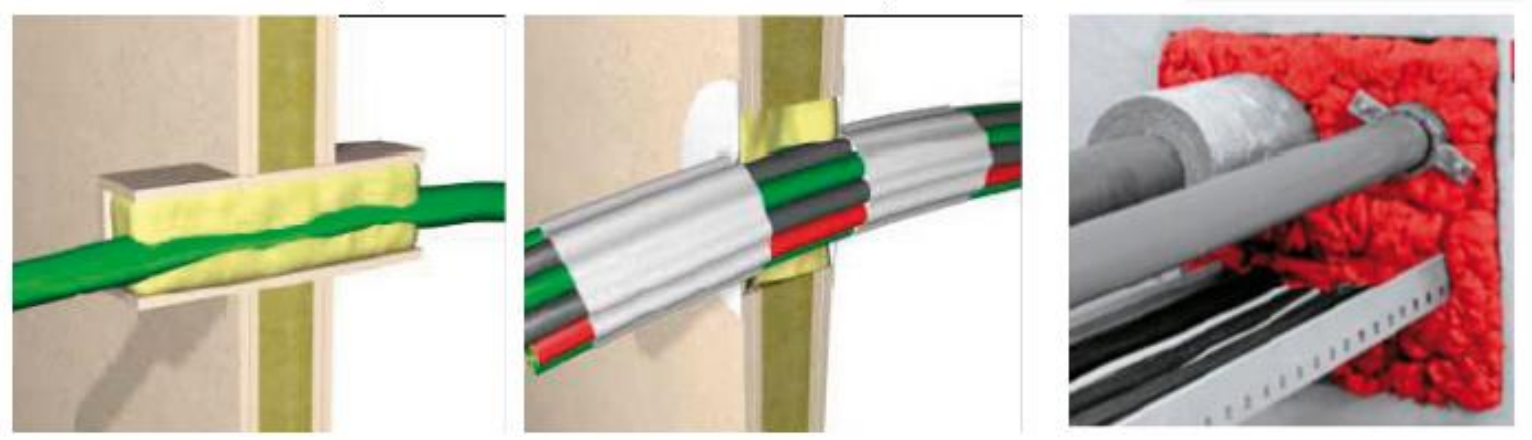

Fonte: Klippel e Just (2018) 
5.7.4.5. Prumadas verticais entre elementos de vedação horizontal (pisos).

As aberturas nos elementos de vedação horizontal para a passagem das instalações elétricas e hidráulicas (shafts) entre pisos devem ser dotadas de selagem corta-fogo, apresentando o mesmo tempo de resistência ao fogo do elemento de vedação para os edifícios habitacionais assobradados. A ABNT NBR 15575:2013 estabelece um critério mínimo de $30 \mathrm{~min}$. para os elementos de vedação do shaft e devem ser detalhadas em projeto e avaliadas por meio de ensaios de resistência ao fogo (BRASIL, 2011).

No caso de prumadas enclausuradas não é requerida a selagem das aberturas de piso, pavimento a pavimento, desde que comprovada sua resistência ao fogo por métodos de ensaios padronizados. Para dutos de lareiras, churrasqueiras e similares deve-se seguir o mesmo procedimento.

\subsubsection{Escadas, elevadores e monta-cargas}

A legislação nacional exige que para escadas usadas como saídas de emergência devem ser constituídas de material incombustível. A ABNT NBR 15575:2013 estabelece um critério mínimo de $30 \mathrm{~min}$. de resistência ao fogo das escadas para edifícios residenciais assobradados e unidades sobrepostas.

Ensaios com elementos de CLT para vedação vertical de escadas usadas como saídas de emergência se mostraram que o sistema resiste mais que 30min. e não foram observadas alterações de temperatura e fumaça no eixo de circulação da escada e poço do elevador durante esse tempo de ensaio (SU e MURADORI, 2015).

Alternativamente, os elementos de CLT de compartimentação da escada podem ser revestidos com materiais de classe I ou II A: essa medida poderia retardar a incidência do fogo e proteger os patamares e degraus e obter a mesma resistência ao fogo requerida. Estas soluções devem ser detalhadas em projeto e avaliadas por meio de ensaios padronizados de resistência ao fogo (BRASIL, 2011). 


\subsubsection{Resistência ao fogo de dispositivos de fixação e conexão}

A proteção dos dispositivos de fixação dos painéis de paredes e pisos contra a ação do fogo de acordo com a ABNT NBR 15575:2013 é determinado pela norma Eurocode 5. A proteção adotada deve garantir resistência ao fogo igual à requerida para a parede estrutural, ou seja, de 30 minutos.

O Eurocode 5 estipula regras para a conexão com vários tipos de fixadores/conexões (pregos, cavilhas, cavilhas, parafusos etc.) entre elementos e componentes, para resistências ao fogo não superiores 60 minutos. Para cada tipo de fixador, além da resistência mínima a ser adotada (ver Tabela 18), podem ser usados métodos para o cálculo da resistência das conexões desprotegidas e protegidas.

Tabela 18 - Resistência mínima dos diferentes tipos de fixadores

\begin{tabular}{c|c|c}
\hline Tipos de Fixadores & $\begin{array}{c}\text { Resistência ao fogo } \mathrm{t}_{\mathrm{d}, \mathrm{fi}} \\
\text { em min. }\end{array}$ & Dimensões \\
\hline Prego & 15 & $\mathrm{~d} \geq 2,8 \mathrm{~mm}$ \\
\hline Parafuso & 15 & $\mathrm{~d} \geq 2,8 \mathrm{~mm}$ \\
\hline Parafuso sextavado com porca & 15 & $\mathrm{t}_{1} \geq 45 \mathrm{~mm}$ \\
\hline Cavilha & 20 & $\mathrm{t}_{1} \geq 45 \mathrm{~mm}$ \\
\hline Conectores de acordo com EN 912 & 15 & $\mathrm{t}_{1} \geq 45 \mathrm{~mm}$ \\
\hline
\end{tabular}

Fonte: European Committee for Standardisation - EN 1995 1-2: Eurocode 5 (2004)

\section{Legenda:}

d - diâmetro do fixador;

$t_{1}$ - espessura do elemento.

De acordo com o EN 1995 1-2: 2004 para conexões sem proteção com cavilhas, pregos ou parafusos com cabeças não salientes, o tempo de resistência ao fogo ( $\mathrm{t}_{\mathrm{d}, \mathrm{fi}}$ ) pode ser aumentado por períodos maiores que os indicados na Tabela 18, mas não superiores a 30 minutos. Este aumento (afi) pode ser alcançado por meio das seguintes medidas:

a) aumento da espessura dos elementos; 
b) aumento da largura dos elementos;

c) aumento da distância final e da aresta aos elementos de fixação.

Onde:

$$
a_{f i}=\beta_{n} k_{f l u x}\left(t_{\text {req }}-t_{\text {di,fi }}\right) \quad \text { (Equação 9) }
$$

- ßn é a taxa de carbonização de acordo com a tabela 3.1do EN 1995 1-2: 2004;

- kflux é um coeficiente que leva em consideração o aumento do fluxo de calor através do fixador;

- treq é o período padrão exigido de resistência ao fogo;

- td,fi é o período de resistência ao fogo da conexão desprotegida da Tabela16.

Nota: O fator kflux deve ser considerado como kf1 ux 1,5 (EN 1995 1-2:2004).

Quando os fixadores são protegidos, o tempo para início de carbonização (tchar) deve ser maior ou igual o tempo de resistência exigida (treq) e ser subtraída do índice do coeficiente de proteção multiplicado pelo período de resistência ao fogo do fixador. Conforme o exemplo dado no EN 1995 1-2:2004, para placa de gesso drywall resistente ao fogo:

$$
t_{c h} \geq t_{\text {req }}-1,2 t_{d, f i}
$$

(Equação 10)

Nota: Coeficiente de proteção para a placa de gesso acartonado resistente ao fogo $K_{2}=1,2$ (EN 1995 1-2:2004).

O Eurocode 5 também dá diversas orientações quanto a espaçamento entre conectores, espaços de embutimentos e outras disposições que também podem ser consultadas diretamente na EN 1995 1-2:2004, como seguem:

a) o espaçamento máximo de pregos e parafusos em torno do perímetro deve ser de $150 \mathrm{~mm}$ e $250 \mathrm{~mm}$, respectivamente;

b) a penetração mínima (comprimento) deve ser oito vezes o diâmetro do fixador para painéis de suporte de carga e seis vezes o diâmetro do fixador para painéis sem carga;

c) para placas de gesso acartonado, o perímetro e o espaçamento interno dos parafusos não devem ser maiores que $200 \mathrm{~mm}$ e $300 \mathrm{~mm}$ respectivamente; 
d) para painéis de gesso acartonado com classificação de resistência ao fogo, o comprimento de penetração (la) dos fixadores na seção transversal residual acima da camada carbonizada não deve ser inferior a $10 \mathrm{~mm}$, ver figura 61 ;

e) as bordas do painel devem ser bem unidas com uma folga máxima de 1 $\mathrm{mm}$.

f) para painéis constituídos por várias camadas, suas juntas devem ser escalonadas em pelo menos $60 \mathrm{~mm}$;

g) para painéis revestidos por várias camadas, cada uma deve ser fixada individualmente e as juntas devem ser escalonadas pelo menos $60 \mathrm{~mm}$;

h) o espaçamento dos fixadores não deve ser superior a $200 \mathrm{~mm}$ ou 17 vezes a espessura do painel $h_{p}$, ou o que for menor;

i) a distância da borda não deve ser maior que 3 vezes a espessura do painel $h_{p}$ e não deve ser menor que 1,5 vezes ou $15 \mathrm{~mm}$ ou o que for menor.

Figura 61 - Elementos de madeira protegidos por placas de gesso acartonado - Exemplos de comprimento de penetração do fixador na madeira não carbonizada.

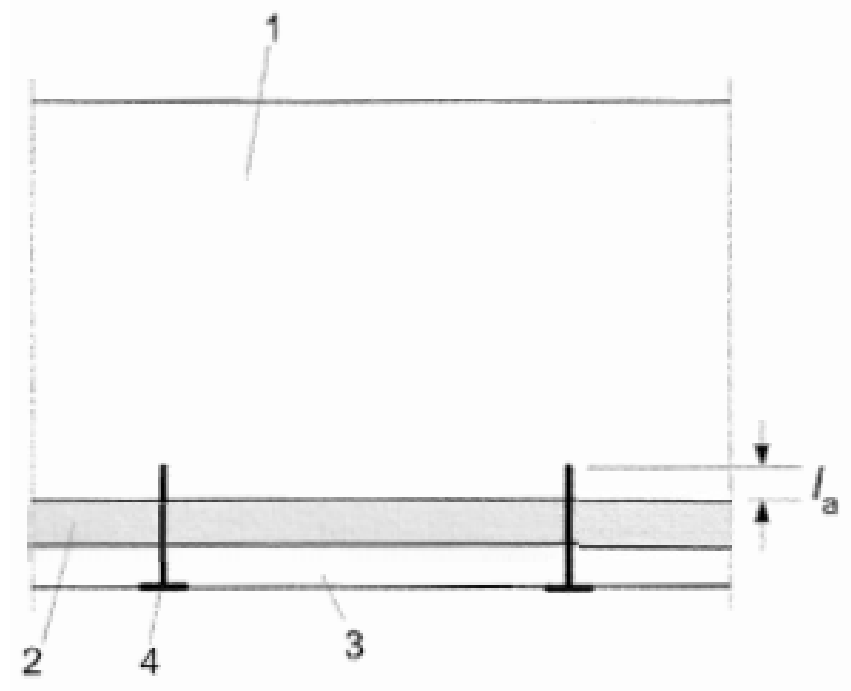

Fonte: European Committee for Standardisation - EN 1995 1-2: Eurocode 5 (2004)

Legenda:

1 - Elemento de madeira

2 - Isolante

3 - Placa de gesso acartonado

4 - Fixador

$\mathrm{l}_{\mathrm{a}}$ - Comprimento acima da camada carbonizada

$a_{\mathrm{fi}}$ - Espessura da camada protetora

$h_{p}$ - Espessura do elemento 
No Brasil não se considera a resistência ao fogo para componentes de fixação e sim para o elemento construtivo. Então, nos painéis de CLT constituídos por camadas de madeira maciça, por não serem elementos homogêneos, deve ser considerado o comprimento dos fixadores para que estes penetrem além da zona da camada carbonizada ( $d_{c h a r}$ e da camada afetada pela temperatura ( $\left.d_{0}\right)$ deve ser considerada sem resistência para que em situação de incêndio possa oferecer estabilidade entre os elementos e componentes fixados entre si. Além disso, também deve ser observado o dimensionamento em relação aos espaçamentos e distâncias da aresta do painel.

O Quadro 6 apresenta um resumo dos parâmetros para os requisitos da norma de desempenho para o sistema construtivo de CLT.

Quadro 6 - Resumo dos parâmetros de projeto para o CLT segundo os requisitos da ABNT NBR 15575:2003

\begin{tabular}{|c|c|c|}
\hline \multicolumn{3}{|c|}{ SEGURANÇA AO FOGO PARA O SISTEMA CONSTRUTIVO DE CLT } \\
\hline $\begin{array}{c}\text { REQUISITOS } \\
\text { DA NBR } \\
15575 \\
\end{array}$ & DESCRIÇÃO & PARÂMETROS PARA PROJETO \\
\hline $\begin{array}{l}\text { 1. Dificultar } \\
\text { o princípio } \\
\text { de incêndio }\end{array}$ & $\begin{array}{l}\text { Proteção contra; } \\
\text { 1.Descargas } \\
\text { atmosféricas; } \\
\text { 2.Risco de ignição } \\
\text { nas instalações } \\
\text { elétricas; } \\
\text { 3.Risco de } \\
\text { vazamento de gás. }\end{array}$ & $\begin{array}{l}\text { - O sistema de proteção contra descargas atmosféricas } \\
\text { conforme NBR 5419-4:2015, legislação vigente e } \\
\text { declaração de atendimento Resistência de contato em } \\
\text { função do material do piso } \geq 100 \\
\text { - Instalações elétricas conforme NBR } 5410 \text {. Classe CA2 } \\
\text { (edifícios habitacionais construídos com materiais } \\
\text { combustíveis) Ver itens 5.7.4.4 e 5.7.4.5 } \\
\text { Instalações de gás e sua execução conforme NBR } \\
13523 \text { e NBR 15526. .SVV TRRF } 120 \text { min e ensaio de } \\
\text { acordo com a NBR } 6479 \\
\text { Componentes e elementos montados, envolvidos ou } \\
\text { separados por materiais resistentes à temperatura } \\
\text { como materiais não combustíveis, combustíveis com } \\
\text { índice de inflamabilidade controlada, com baixa } \\
\text { condutividade térmica ou madeira tratada com } \\
\text { retardantes de chamas ou qualquer outro material que } \\
\text { resista a temperatura acima de } 1120^{\circ} \mathrm{C} \text {, conforme o } \\
\text { método de ensaio ISO 540. Exemplos de materiais } \\
\text { concreto, fibra mineral e cerâmica. Ver itens 5.7.4.4 e } \\
5.7 .4 .5\end{array}$ \\
\hline $\begin{array}{l}\text { 2. Dificultar } \\
\text { a ocorrência } \\
\text { de } \\
\text { inflamação } \\
\text { generalizada }\end{array}$ & $\begin{array}{l}\text { 1. Avaliação da } \\
\text { reação ao fogo da } \\
\text { face inferior do } \\
\text { sistema de piso } \\
\text { (laje); } \\
\text { 2. Avaliação da } \\
\text { reação ao fogo da } \\
\text { face superior do } \\
\text { sistema de piso; } \\
\text { 3. Avaliação da } \\
\text { reação ao fogo da }\end{array}$ & $\begin{array}{l}\text { - Classificação painéis de vedação D-s2, d0, classe } \\
\text { Brasil IV A } \\
\text { Classificação painéis de vedação com retardante classe } \\
\text { C (flashover após 10-100 kW) ou B (sem flashover), } \\
\text { Classe IIA e IIIA } \\
\text { - Sistema e os elementos com características de } \\
\text { propagação de chamas controladas, assim como os } \\
\text { materiais de revestimento, acabamento e isolamento } \\
\text { termo acústico empregados na face interna destes; }\end{array}$ \\
\hline
\end{tabular}




\begin{tabular}{|c|c|c|}
\hline & \begin{tabular}{|l} 
face interna do \\
sistema de \\
vedação vertical; \\
4. Reação ao fogo \\
da face interna do \\
sistema de \\
cobertura das \\
edificações; e \\
5. Reação ao fogo \\
da face externa do \\
sistema de \\
cobertura das \\
edificações.
\end{tabular} & $\begin{array}{l}\text { - Elementos de CLT para parede conforme o método de } \\
\text { ensaio EN 13823. SMOGRA } \leq 30 \mathrm{~m}^{2} \mathrm{~s}^{2} \text { e TSP } 600 \mathrm{~s} \leq 50 \\
\mathrm{~m}^{2} \text {. } \\
\text { - Elementos de piso de CLT conforme o método de ensaio } \\
\text { ABNT NBR 8660. Classificação painéis de piso Dfl } \\
\text { classe Brasil IV A. } \\
\text { - Classificação de acordo com a NBR 16626:2017. } \\
\text { - Painel com tratamento de conservantes contra ataques } \\
\text { de organismos xilófagos, ensaiado com base na norma } \\
\text { EN 15228:2009 item 4.4. } \\
\text { - Finger joints espaçamento } \leq 2 \mathrm{~mm} \text { ). A BS EN } \\
16351: 2015 \text { orienta que a avaliação do comportamento } \\
\text { ao fogo da junção das lamelas no sentido longitudinal } \\
\text { (finger joints) deve ser realizada com base na norma BS } \\
\text { EN 14081-1:2005 (última revisão BS EN 14081-1:2016+ } \\
\text { A1:2019) }\end{array}$ \\
\hline $\begin{array}{l}\text { 3. Dificultar } \\
\text { a } \\
\text { propagação } \\
\text { de incêndio }\end{array}$ & $\begin{array}{l}\text { 1. Avaliação da } \\
\text { reação ao fogo da } \\
\text { face externa das } \\
\text { paredes que } \\
\text { compõem a } \\
\text { fachada } \\
\text { 2. Resistência ao } \\
\text { fogo de elementos } \\
\text { de } \\
\text { compartimentação } \\
\text { entre pavimentos } \\
\text { e elementos } \\
\text { estruturais } \\
\text { associados }\end{array}$ & $\begin{array}{l}\text { - Juntas contínuas, e as instalações (seladas com } \\
\text { selantes, massas, colarinhos/anéis corta fogo, etc.), } \\
\text { para evitar a propagação do fogo entre as interfaces } \\
\text { dos elementos de CLT. Itens 5.6, 5.7.5.4 e 5.7.5.5 ( ver } \\
\text { detalhes Figura 46,53,57 e 60) } \\
\text { - Para o CLT se aplica o método de ensaio EN 13823, e } \\
\text { (SMOGRA } \leq 30 \mathrm{~m}^{2} \mathrm{~s}^{2} \text { e TSP600s } \leq 50 \mathrm{~m}^{2} \text { ). } \\
\text { - A avaliação de resistência ao fogo irá determinar a } \\
\text { espessura mínima de resistência ou a proteção } \\
\text { necessária do elemento de acordo com sua função e } \\
\text { para obter a distância mínima entre edifícios. } \\
\text { Para habitações unifamilares elementos de } \\
\text { compartimentação e estruturais devem atender no } \\
\text { mínimo TRRF de } 30 \text { min. } \\
\text { Proteção para os elementos da face externa das } \\
\text { paredes de fachadas ver Figura } 48\end{array}$ \\
\hline $\begin{array}{l}\text { 4. Garantir a } \\
\text { segurança } \\
\text { estrutural } \\
\text { em situação } \\
\text { de incêndio }\end{array}$ & $\begin{array}{l}\text { 1. Resistência ao } \\
\text { fogo dos } \\
\text { elementos de } \\
\text { compartimentação } \\
\text { entre pavimentos } \\
\text { e elementos } \\
\text { estruturais } \\
\text { associados } \\
\text { 2. Resistência ao } \\
\text { fogo dos } \\
\text { elementos } \\
\text { estruturais e de } \\
\text { compartimentação } \\
\text { vertical } \\
\text { 3. Resistência ao } \\
\text { fogo do sistema de } \\
\text { cobertura } \\
\text { 4. Selagem corta- } \\
\text { fogo nas } \\
\text { prumadas elétricas } \\
\text { e hidráulicas } \\
\text { 5. Prumadas } \\
\text { enclausuradas } \\
\text { (shafts) }\end{array}$ & 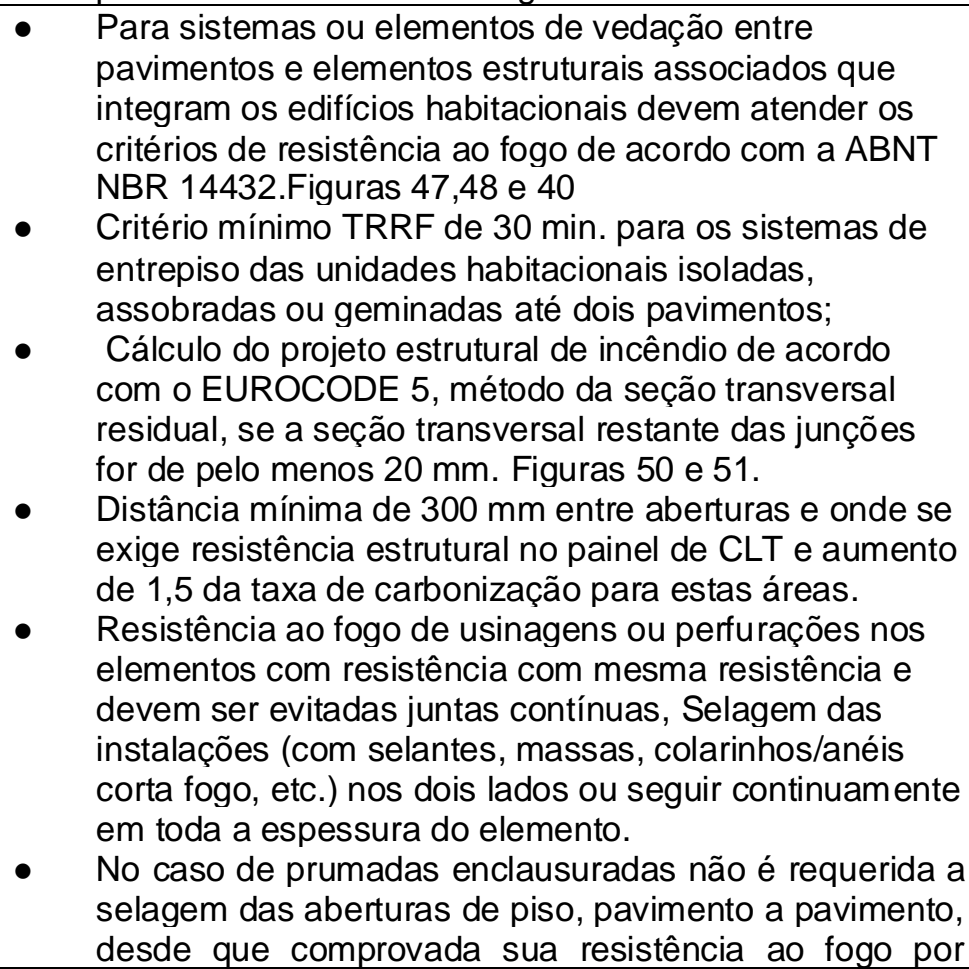 \\
\hline
\end{tabular}




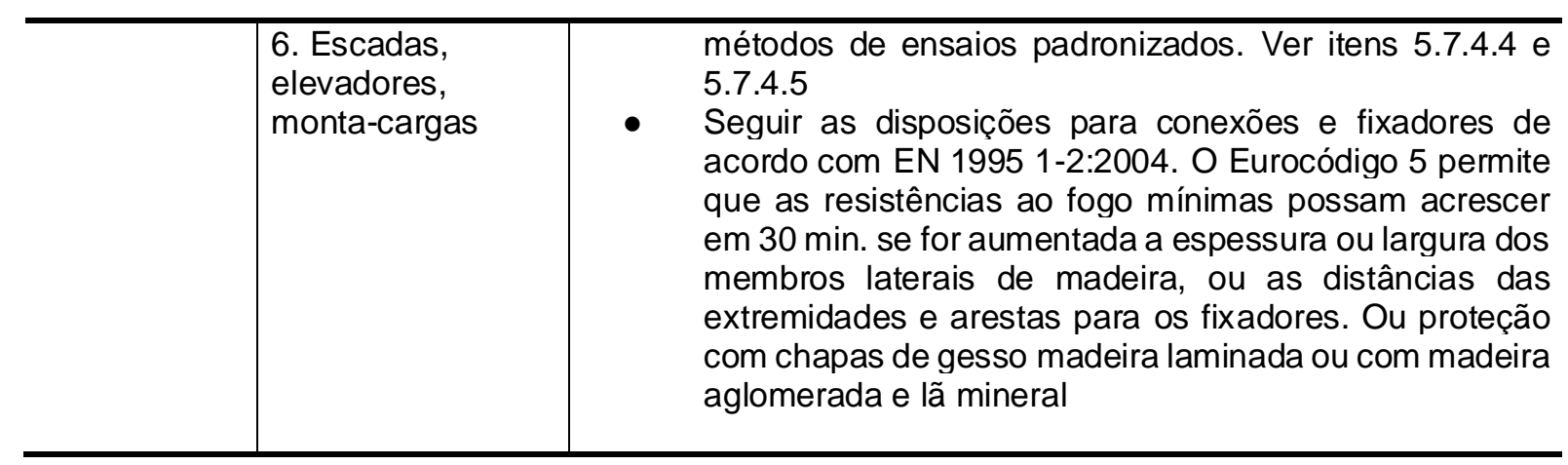

Fonte: da autora (2019)

A seguir, será apresentada a análise de um projeto executado com o sistema em CLT para observar onde haveria potenciais riscos de incêndio num edifício executado no Brasil e, assim, contribuir para a qualidade e segurança das edificações que possam ser construídas futuramente adotando-se este sistema.

\subsection{Projetos em sistema construtivo de CLT no Brasil}

De acordo com o levantamento de OLIVEIRA (2018), existem atualmente 31 edificações construídas no país com o sistema em CLT, divididos em usos comerciais, serviços e residenciais, sendo que destes mais da metade são de uso residencial unifamiliar.

O exemplo aqui analisado é de um edifício residencial unifamiliar onde foram construídos anexos com o sistema em CLT. O edifício localiza-se na cidade de Valinhos no Estado de São Paulo, e os anexos são divididos em dois blocos de área total construída de $285,00 \mathrm{~m}^{2}$, sendo um bloco de garagem $125,16 \mathrm{~m}^{2}$ e outro de um estúdio para hóspedes com 159,84 $\mathrm{m}^{2}$ de área construída (Figuras 63 a 65). Os blocos estão em um terreno onde já existia uma edificação principal construída com alvenaria convencional, como mostra a implantação na Figura 63. 
Figura 62 - Bloco do estúdio de hóspedes

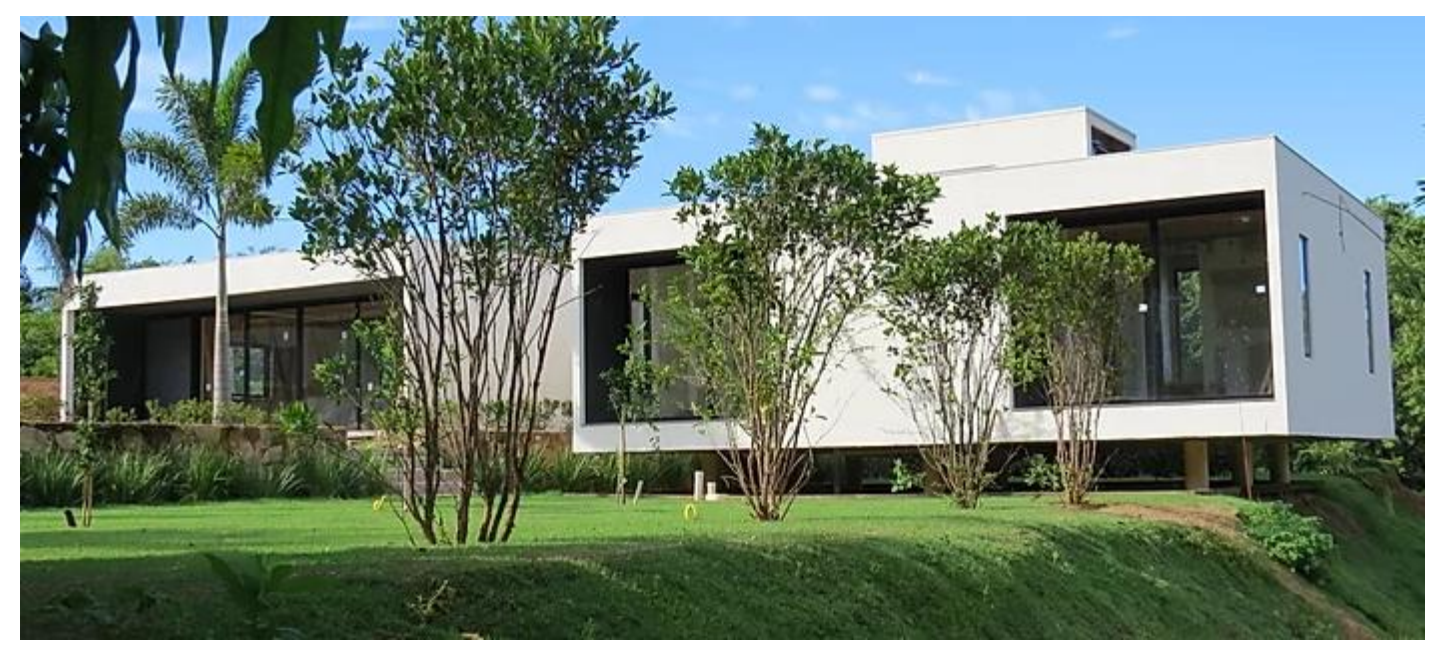

Fonte:Castilho (2019)

Figura 63 - Implantação da edificação em Valinhos, SP

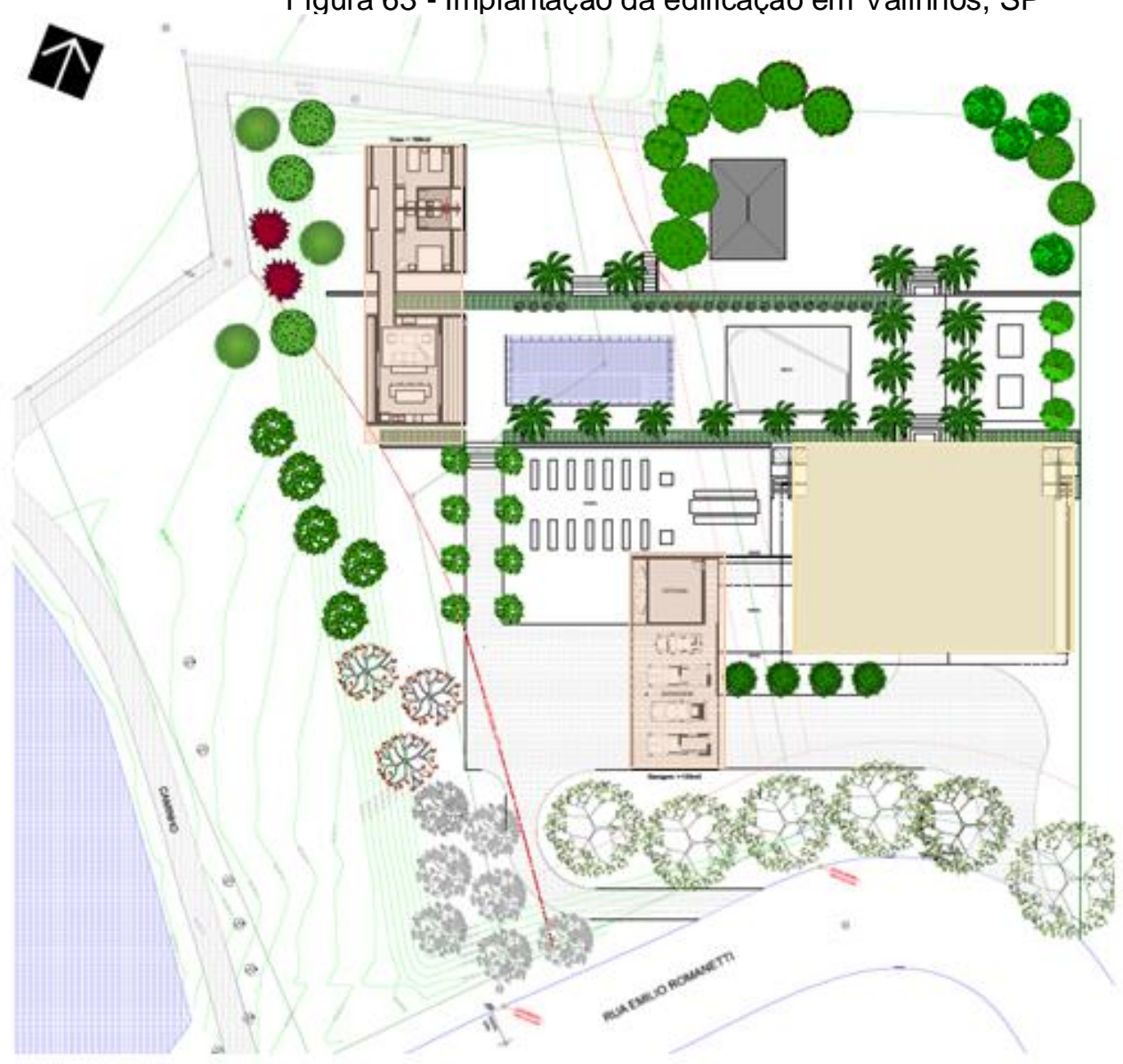

Bloco principal existente em alvenaria convencional

Blocos novos em CLT

Fonte: Castilho (2019) 
Figura 64 - Planta do estúdio de hóspedes e garagem
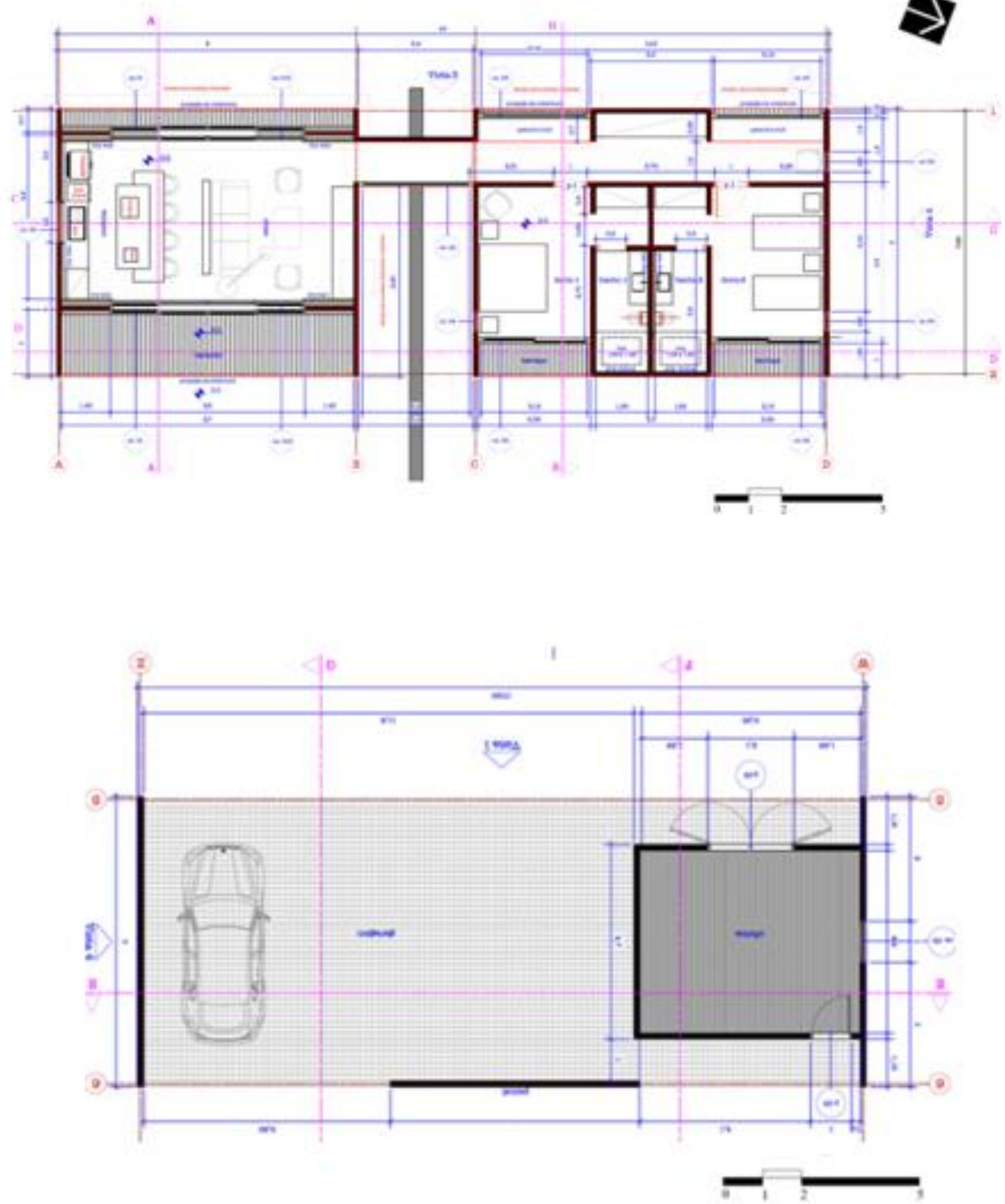

Fonte: Castilho (2019) 
Figura 65 - Cortes longitudinal e transversal do estúdio de hóspedes
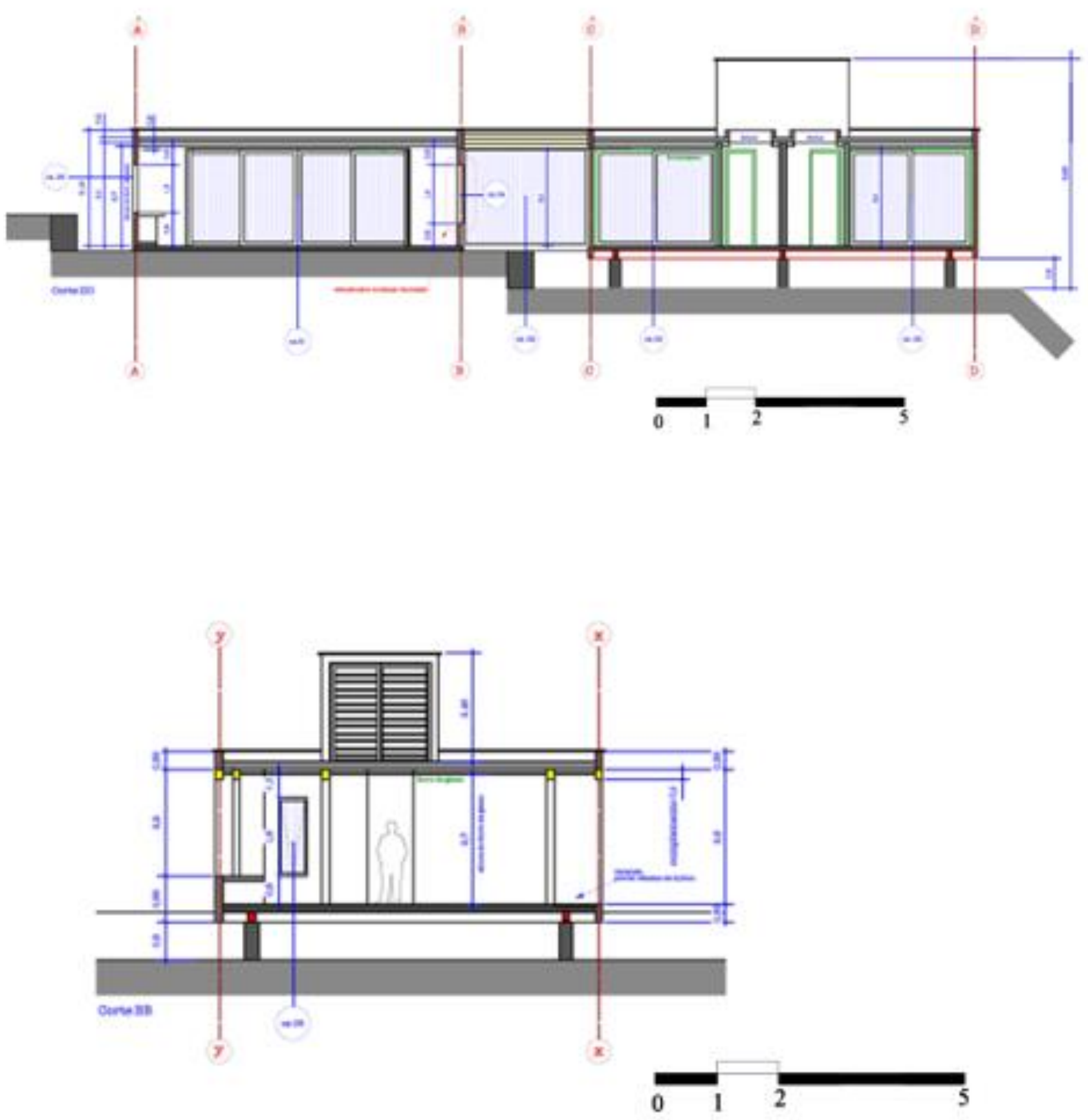

Fonte: Castilho (2019) 
Em visita à obra e ao escritório do autor do projeto foi levantada uma base documental por meio de fotos e com os arquivos de projeto para a análise.

As espessuras dos painéis utilizados para a execução dos blocos foram: paredes internas $80 \mathrm{~mm}$ (três camadas com lamelas de 20+40+20 mm), externas $100 \mathrm{~mm}$ (cinco camadas com lamelas de $20 \mathrm{~mm}$ cada) e para lajes de piso e cobertura $140 \mathrm{~mm}$ (cinco camadas com lamelas 40+20+20+20+40 mm) e $60 \mathrm{~mm}$ (três camadas com lamelas de $20 \mathrm{~mm}$ ) respectivamente.

Para o bloco da garagem foi executada fundação radier, diretamente na superfície do solo abrangendo toda a projeção do edifício e depois foi feito um nivelamento com a execução de uma fiada de canaleta cerâmica de $14 \times 19 \times 29 \mathrm{~cm}$ preenchidas com concreto. No bloco destinado para o estúdio de hóspedes foram utilizados dois tipos de fundação devido ao desnível do terreno. Na parte onde estão situadas a cozinha e a sala de estar, a fundação utilizada foi tipo radier e a outra parte onde se encontram as suítes foram executados nove pilotis de concreto armado onde se apoiam três vigas metálicas tipo "I" e depois fixados aos painéis de piso das suítes de hóspedes (Figura 66).

Figura 66 - Fundação do bloco do estúdio de hóspedes
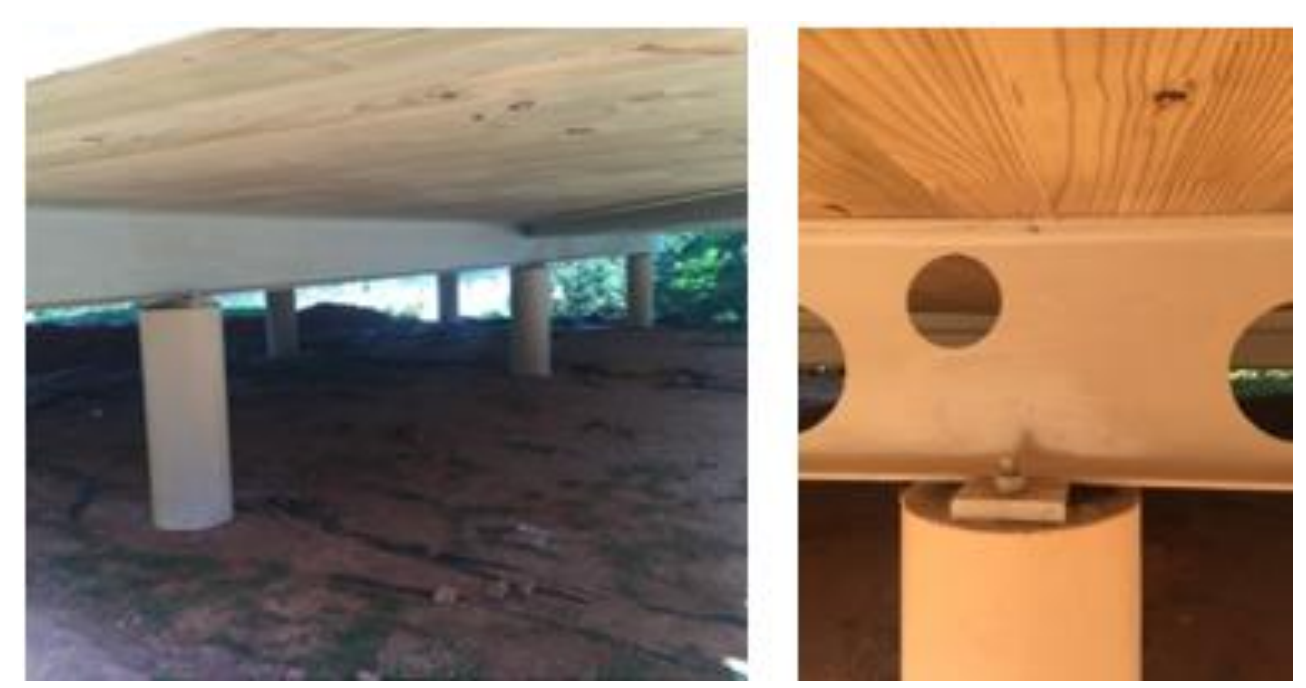

Fonte: da autora (2018) 
A montagem dos blocos foi feita in loco, ou seja, os painéis foram transportados até o terreno e os elementos de vedação foram conectados entre si conforme o projeto de planejamento do fabricante, como indicado nas Figuras 67 a 70.

Figura 67 - Esquema dos painéis de CLT do estúdio de hóspedes

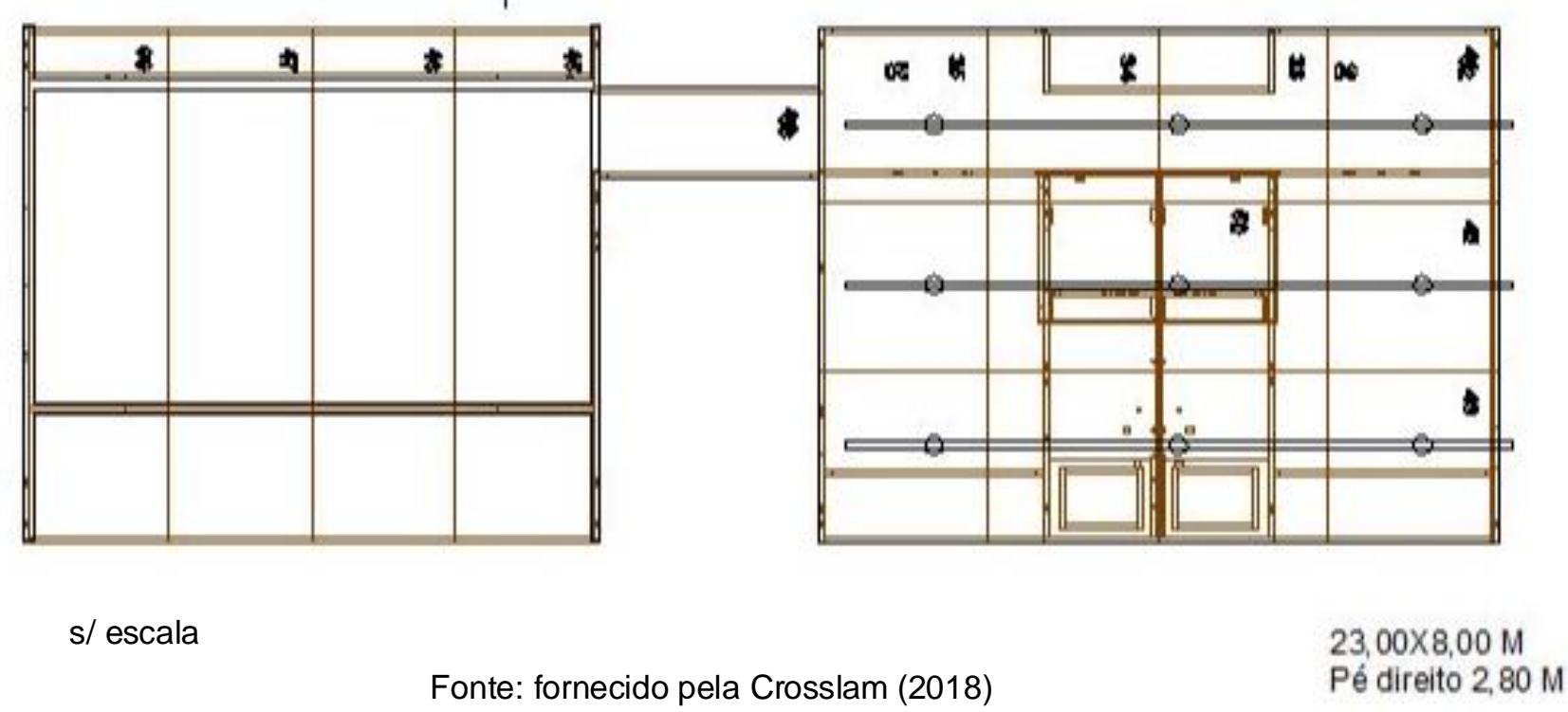

Figura 68 - Esquema dos painéis de CLT da garagem

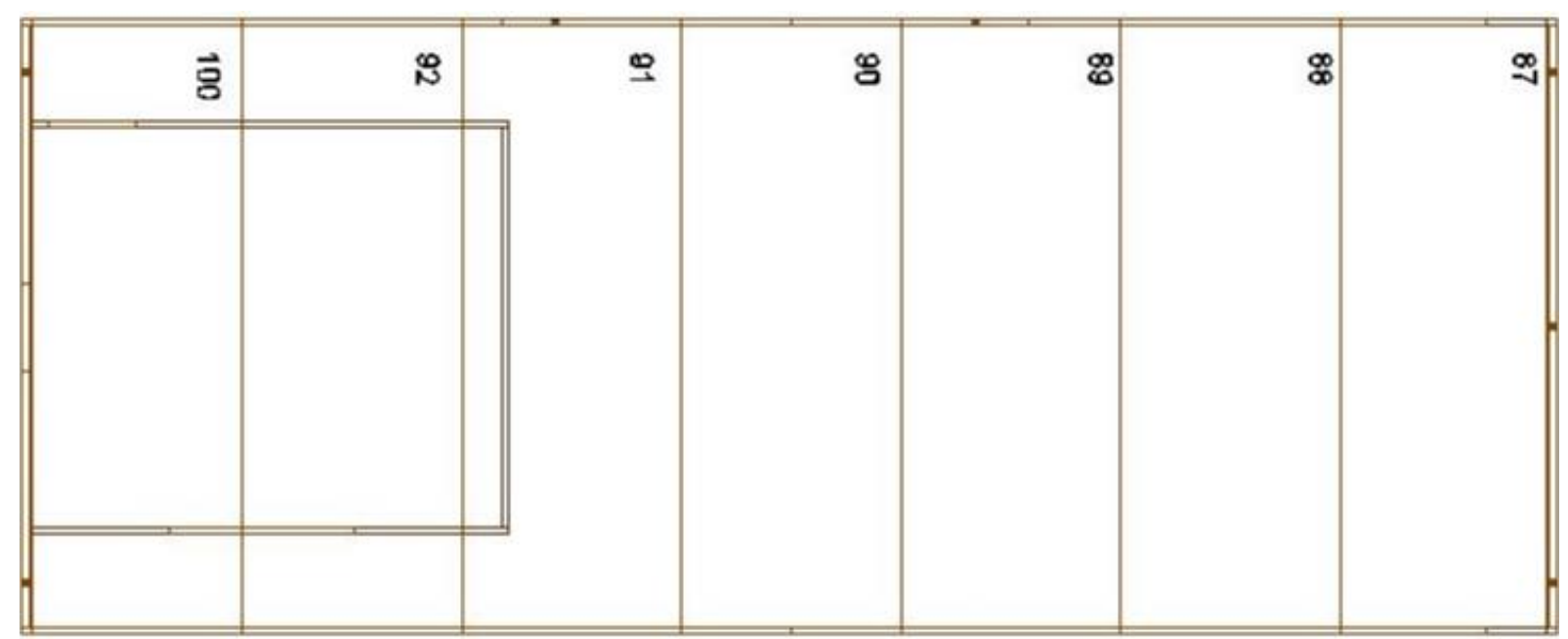

s/ escala

Fonte: fornecido pela Crosslam (2018) 
Figura 69 - Perspectiva dos painéis de CLT do estúdio de hóspedes

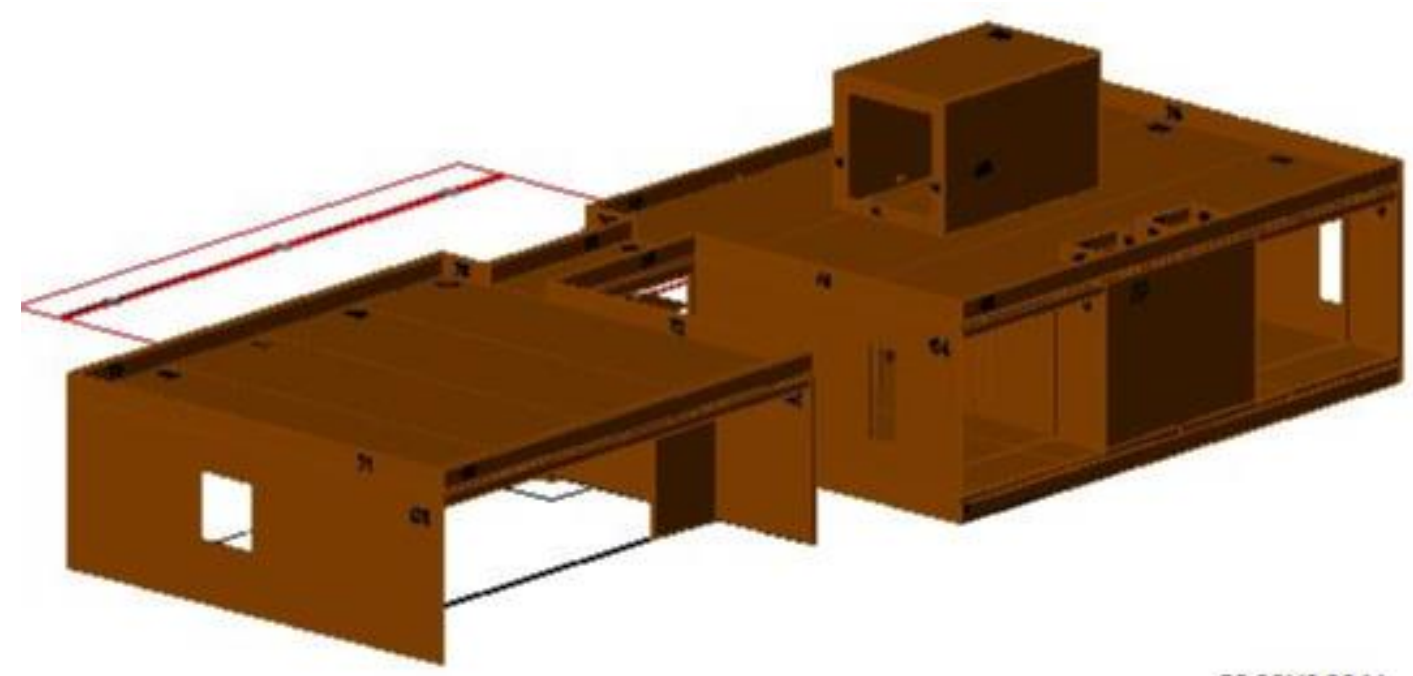

$23.00 \times 8.00 \mathrm{M}$

Pé direto $280 \mathrm{M}$

s/escala

Fonte: fornecido pela Crosslam (2018)

Figura 70 - Perspectiva dos painéis de CLT da garagem

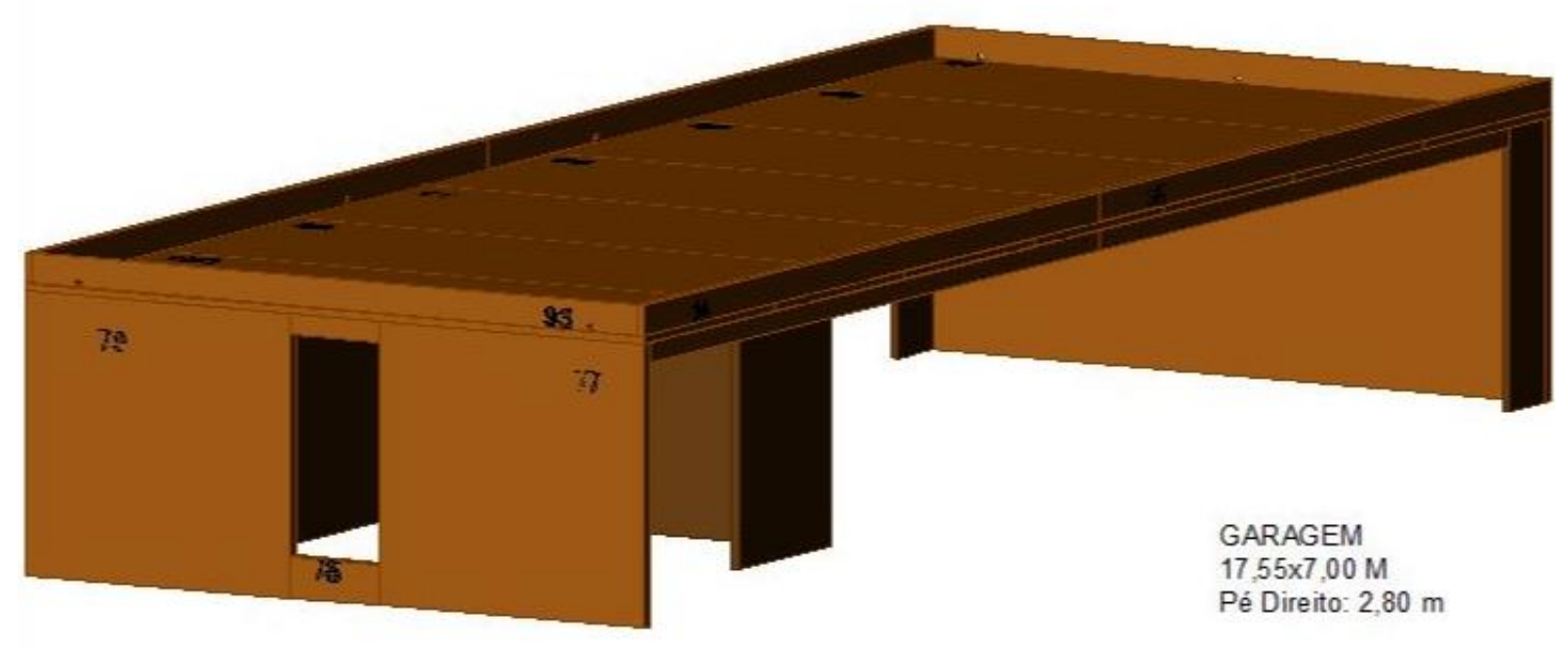

s/escala

Fonte: fornecido pela Crosslam (2018) 
Entre os painéis de paredes externas de CLT e a fiada de canaletas cerâmicas foram instaladas fitas de vedação (elastômeros) para evitar a ascensão de umidade da fundação para o elemento de madeira, no caso foi utilizado EPDM (etilenopropilenodieno-monômero). Em sequência, os painéis para vedação externa foram conectados com chapas e cantoneiras de metálicas e parafusos HBS com diâmetro de $8 \mathrm{~mm}$ e $80 \mathrm{~mm}$ de comprimento (Figura 71).

Os elementos de vedação vertical internos foram conectados com parafusos VGZ da empresa italiana Rothoblaas ${ }^{\circledR}$, com representação comercial no Brasil, na inclinação de $45^{\circ}$ (Figura 71) e revestidos com uma camada de placa de gesso acartonado tipo standard de $12 \mathrm{~mm}$. Nas áreas úmidas foi utilizada uma camada de placas de gesso acartonado tipo $\mathrm{RU}$ (resistente à umidade) de $12 \mathrm{~mm}$ e depois revestida com material cerâmico. O painel da laje de cobertura, na parte interna, também recebeu placas de gesso e posterior pintura para o acabamento.

Figura 71 - Exemplos de fixação dos painéis de CLT fotos superior direita e esquerda parafuso VGZ, fotos inferior esquerda cantoneira e da direita chapa reta

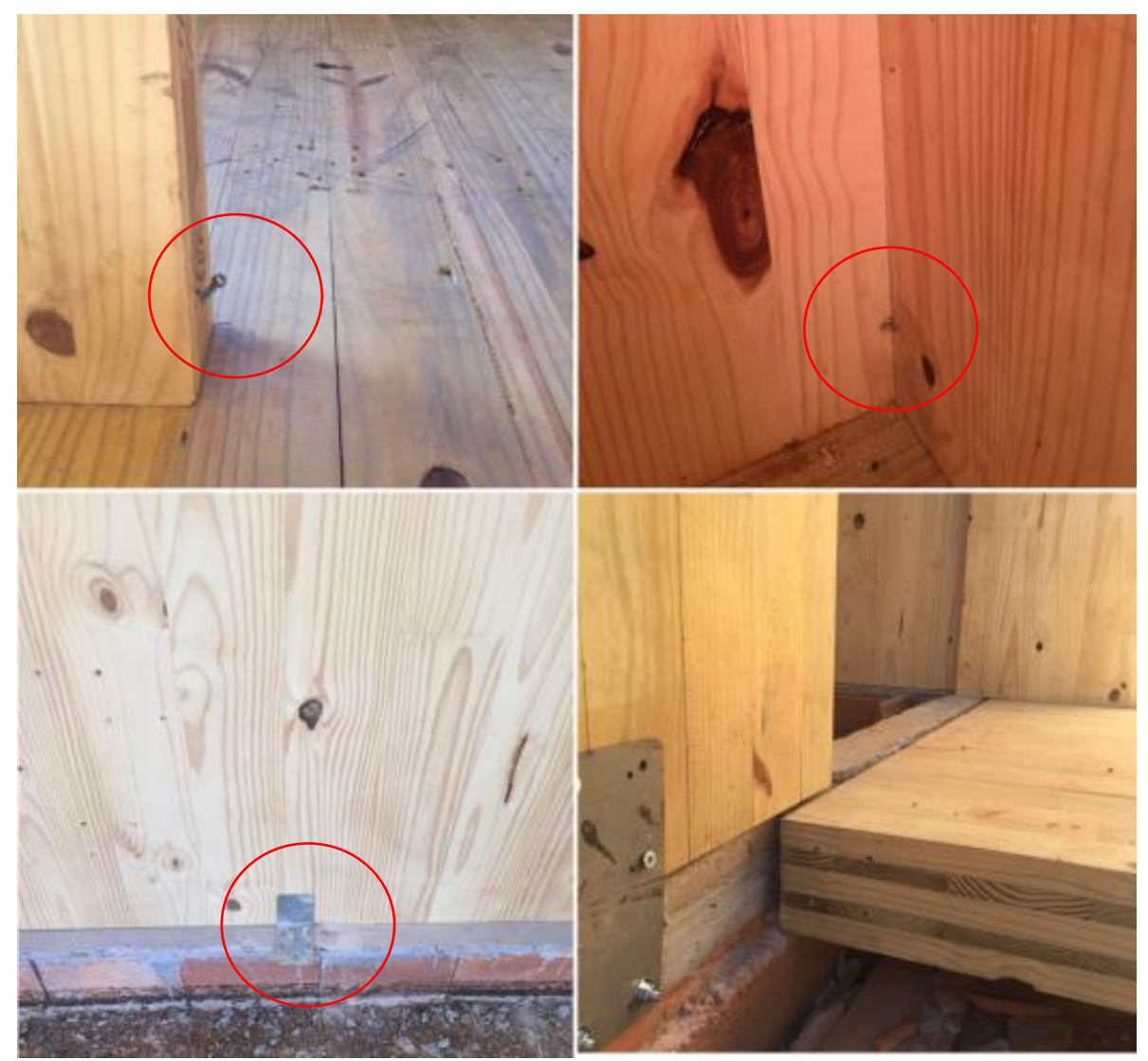

Fonte: da autora (2018) 
Os painéis externos vieram da fábrica com tratamento à base de $\mathrm{CCB}$, preservante contra ataques de organismos xilófagos. Na fachada, foi aplicado o sistema EIFS (Exterior Insulation and Finish System), sistema de seis camadas composto de placas de poliestireno expandido (EPS). A composição é feita aplicando-se diretamente sobre o painel de CLT uma membrana impermeável contra água e ar que protege as juntas entre placas de possíveis penetrações. $\mathrm{Na}$ sequência, o adesivo monocomponente de base cimentícia é aplicado, uma camada de EPS, uma camada com tela de reforço e a última camada de textura como mostra a Figura 72. Segundo o autor do projeto, para esta obra foi produzido um revestimento específico para o sistema CLT, adaptado dos sistemas de fachada utilizados para o sistema Wood framing.

Também foi especificado um segundo revestimento com ripas de madeira termotratada, isto é, madeira aquecida a uma temperatura de pelo menos $250^{\circ} \mathrm{C}$ protegido com vapor de água. Esta técnica provoca alterações físicas e químicas conferindo à madeira maior durabilidade, tonalização da cor, melhor isolamento térmico e estabilidade dimensional além de outras características. Este revestimento é aplicado por meio de barrotes de madeira e há uma membrana permeável ao vapor e impermeável à água aplicada diretamente no elemento de CLT (Figura 73).

Os painéis de laje de cobertura receberam mantas de impermeabilização sintéticas flexíveis de policloreto de vinila (P.V.C) com única camada (Figuras 73 e 74). Também foram adicionadas vigas metálicas para evitar que ocorra a flexão nestes elementos (Figuras 75 e 76). 
Figura 72 - Modelo da fachada dos blocos com o sistema EIFS
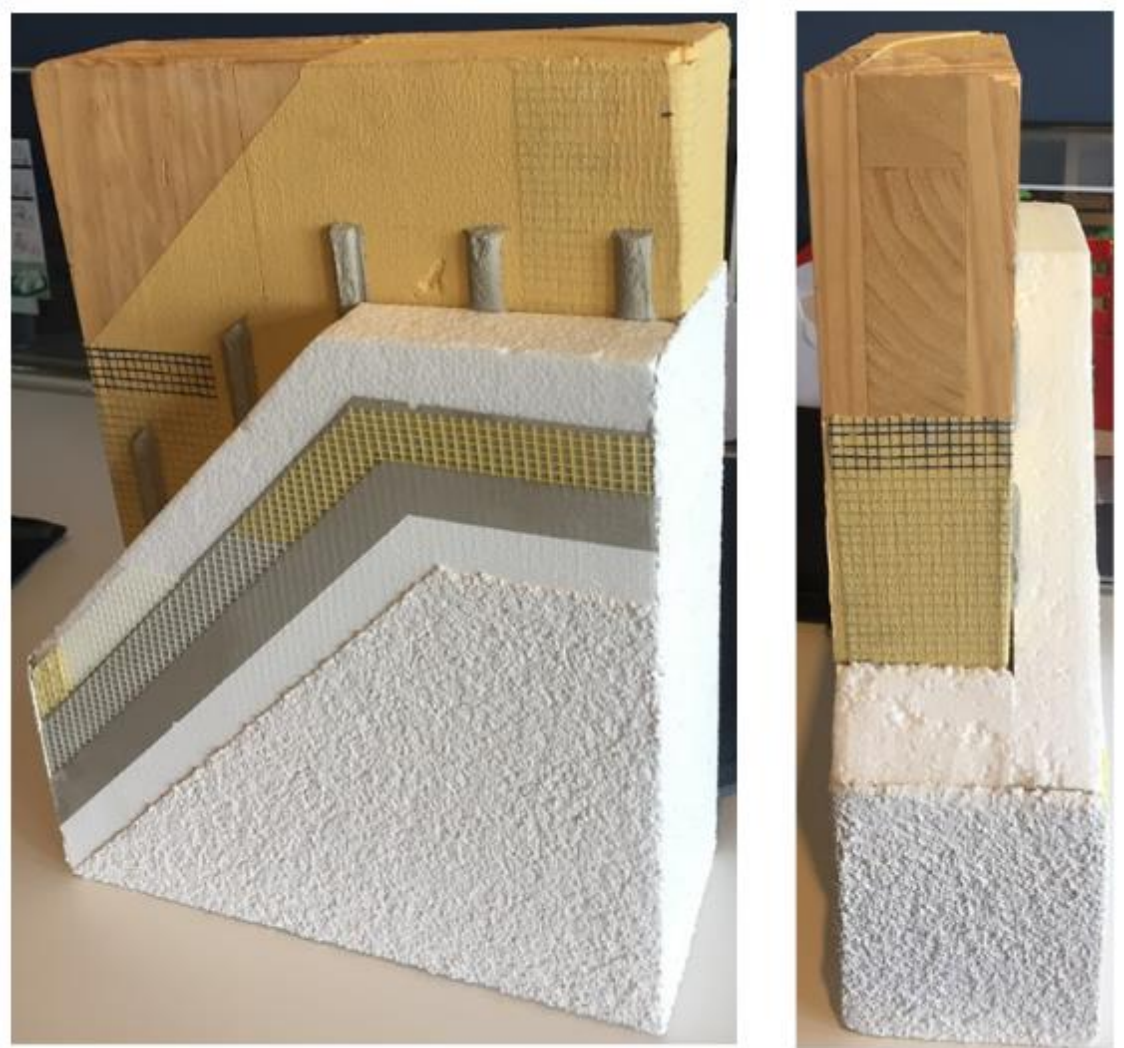

Fonte: Castilho (2019)

Figura 73 - Exemplo de fachada com madeira termotratada

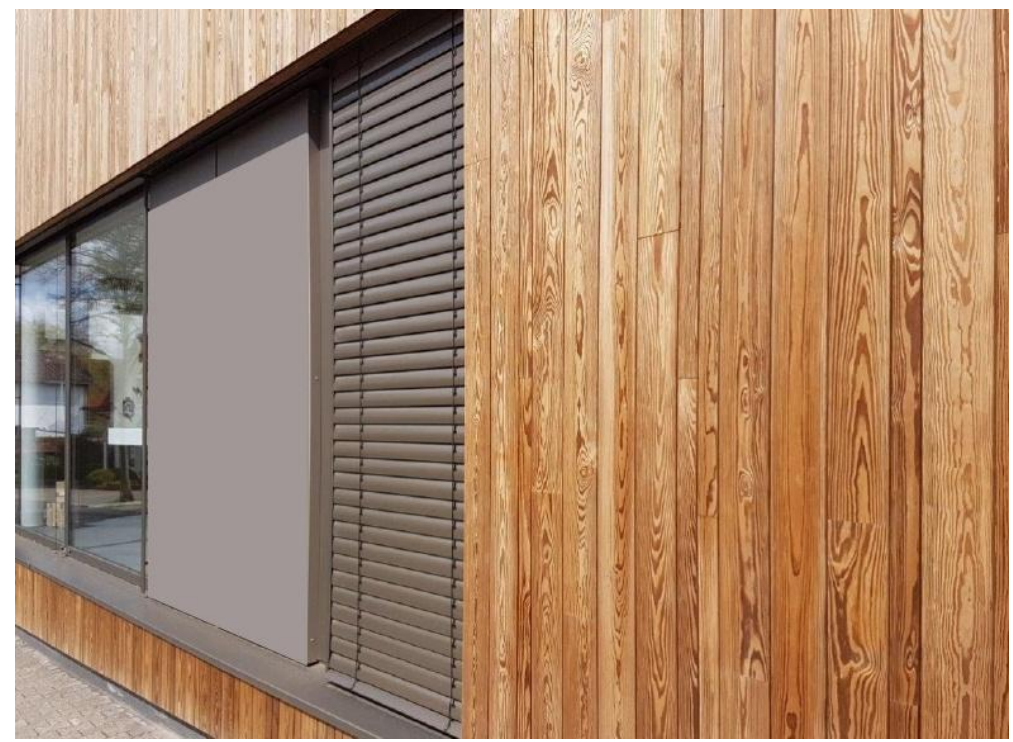

Fonte: Vale do cedro (2019) 
Figura 74 - Laje de cobertura antes da proteção com manta

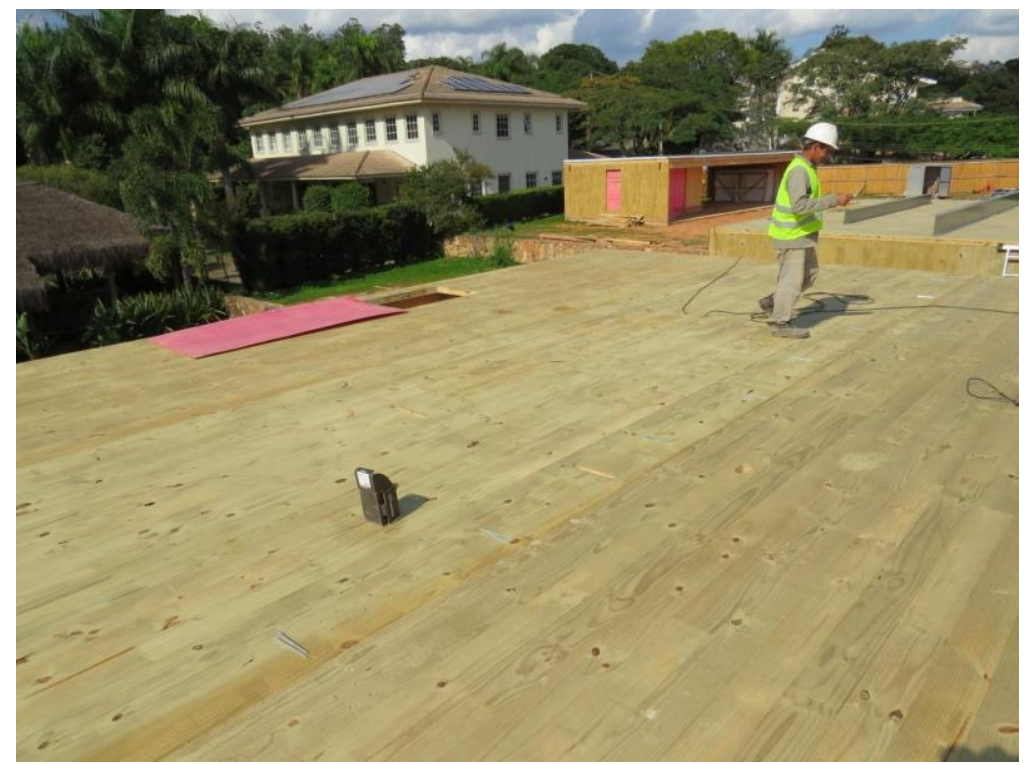

Fonte: da autora (2018)

Figura 75 - Laje de cobertura com manta impermeável

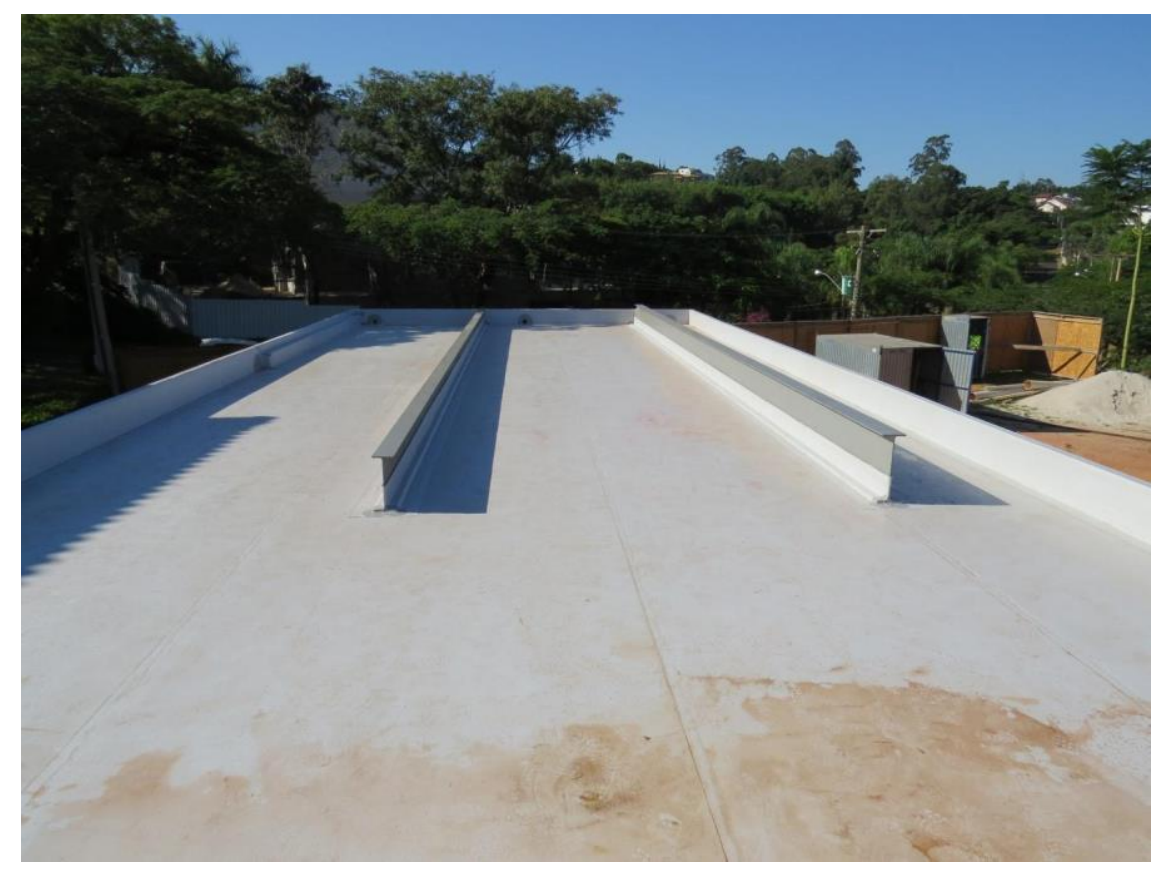

Fonte: Nathan Brito (2018) 
Figura 76- Vigas metálicas para evitar a flexão da laje de piso

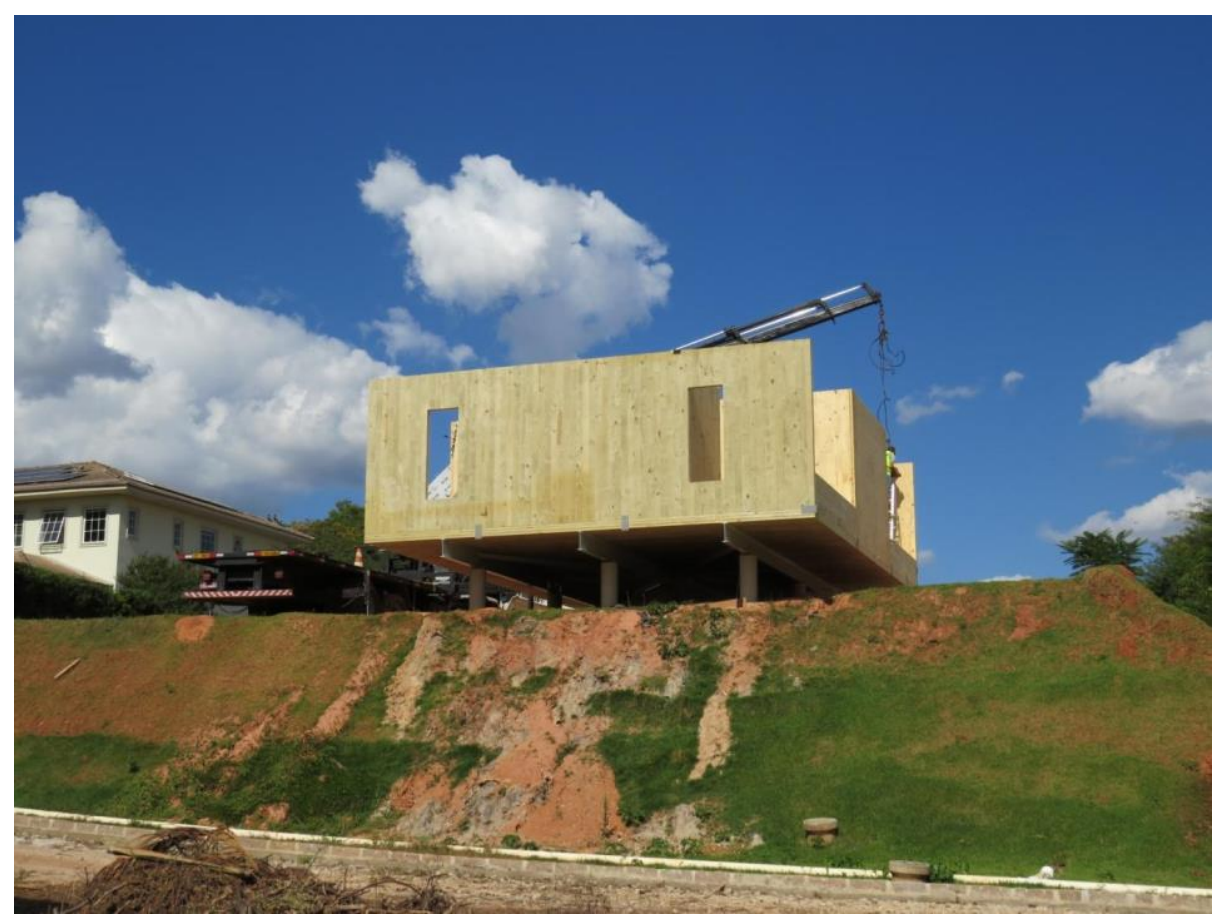

Fonte: Castilho (2019)

Para as instalações elétricas, foram feitos canais para a passagem dos conduítes no sentido longitudinal das lamelas da primeira camada (Figura 77). As instalações hidráulicas nas áreas molhadas e molháveis foram instaladas em frente ao painel e depois revestidas com uma placa de gesso tipo RU e, na sequência, foi aplicado o revestimento cerâmico.

Figura 77 - Canaletas usinadas na fábrica para a instalação de serviços

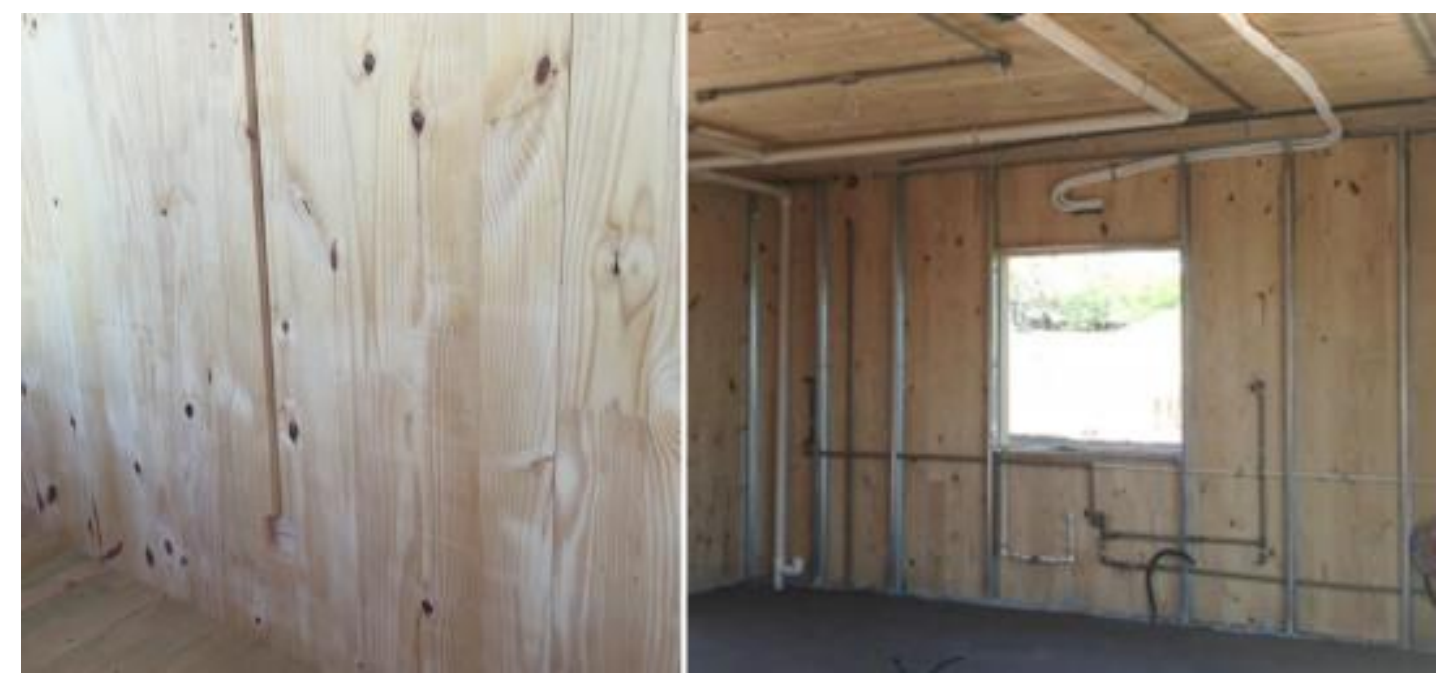

Fonte: Oliveira (2018) 
Figura 78 - Lamelas dispostas na direção da carga (contra verga)

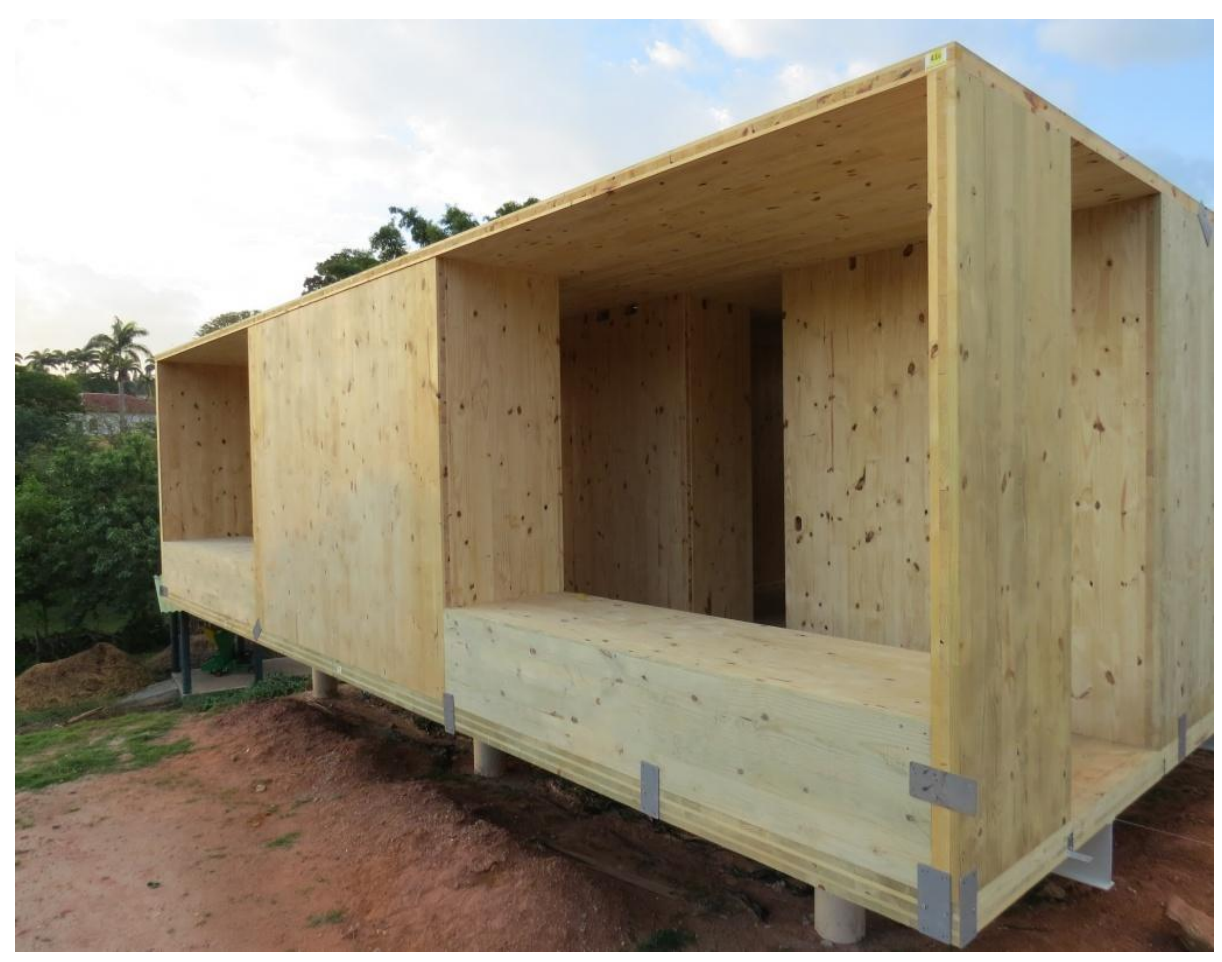

Fonte: Castilho (2019)

A norma de desempenho determina que, para dificultar o princípio de incêndio, sistemas construtivos constituídos por materiais combustíveis devem ter seus componentes e elementos montados, envolvidos ou separados por materiais resistentes à alta temperatura e não combustíveis, ou ser de madeira tratada com retardantes de chamas para evitar a ignição. Nos painéis da obra do caso em estudo a única medida preventiva tomada para este requisito foi a aplicação de uma camada de gesso acartonado em todos os ambientes internos (material resistente a temperatura e não combustível).

As instalações elétricas foram diretamente instaladas nas canaletas usinadas para este fim, sem nenhuma proteção isolante adicional. Foram utilizados somente eletrodutos flexíveis (conduítes), que para a rede de baixa tensão são fabricados para resistirem ao calor e ao fogo (em ensaios realizados em laboratórios, têm que suportar $60^{\circ} \mathrm{C}$ durante 24 horas sem apresentar qualquer deformidade) (AECWEB, 2019). 
Para dificultar a inflamação generalizada, o sistema construtivo de CLT assim como seus elementos devem apresentar características de propagação de chamas controladas, assim como os materiais de revestimento e acabamento.

O painel de CLT usado para parede neste projeto tem espessuras de $60 \mathrm{~mm}(20+20+20)$ e $80 \mathrm{~mm}(20+40+20)$, com lamelas externas de $20 \mathrm{~mm}$. Segundo o princípio da taxa de carbonização, não haverá influência da queda de camadas carbonizadas quando a camada externa tem uma profundidade mínima de $25 \mathrm{~mm}$, no entanto estes painéis com a espessura da lamela externa menor que $25 \mathrm{~mm}$ como recomendado, poderão contribuir para a inflamação generalizada caso a camada de proteção de gesso acartonado se desprenda e assim aumentando potencialmente o risco de colapso principalmente se a parede tiver função estrutural.

Outro ponto a considerar é referente à classificação de reação ao fogo do painel de CLT utilizado na cozinha, pois segundo a norma a classe mínima deve ser IIIA. Se o painel nacional for ensaiado e obtiver a mesma classificação dos painéis semelhantes fabricados no exterior (classe nacional IV), a proteção somente com uma placa de gesso acartonado não será suficiente para atender a classe mínima exigida. Uma medida preventiva adicional seria a aplicação de placa de gesso tipo $\mathrm{F}$ (resistente ao fogo) ou duas placas tipo standard de $12 \mathrm{~mm}$, principalmente na área de cocção dos alimentos.

A ABNT NBR 15575:2013 determina que para evitar a propagação do fogo entre as interfaces dos elementos de CLT, as juntas contínuas e as instalações devem ser seladas (com selantes, massas, colarinhos/anéis corta fogo etc.). As obras executadas com o sistema construtivo de CLT no país costumam receber selantes a base de silicone entre os elementos que compõem o SVV (sistema de vedação vertical) e SVH (sistema de vedação horizontal). Assim deve ser verificada a resistência ao fogo deste composto químico para garantir a selagem, evitando-se a propagação de incêndio além do ambiente de origem e garantindo a estabilidade estrutural de todo o conjunto.

Durante a visita à obra (ainda em execução), verificou-se a existência de vários pontos vulneráveis, como espaços entre as interfaces dos elementos assim 
como pelas conexões que poderiam propagar chamas (Figuras 71). $O$ uso de fitas de EPDM entre as interfaces dos SVV é uma medida que contribuiria para evitar a propagação de chamas e gases, embora o propósito da aplicação na obra fosse para conferir estanqueidade à água e ao ar.

Para evitar a propagação das chamas entre edifícios, neste estudo de caso, seria necessário analisar a proximidade entre o bloco da garagem e o edifício existente. Para um correto dimensionamento do distanciamento seguro, os elementos de CLT da garagem deveriam ser avaliados por ensaios de reação e resistência ao fogo para averiguar se a distância entre os edifícios e assim como especificar a proteção mínima necessária.

Em relação aos revestimentos aplicados do tipo não aderido, para a ventilação da fachada deve-se garantir a instalação de materiais isolantes nos espaços entre perfis metálicos ou barrotes para os elementos de CLT. No exemplo da obra em questão, o revestimento de madeira termotratada foi aplicado por meio de barrotes. Como se trata de um edifício térreo não há perigo de propagação do fogo pela fachada para outro pavimento, mas no caso de edifícios acima de um pavimento, a aplicação de isolantes entre os espaços vazios do revestimento da fachada deve ser considerada.

A fim de garantir a segurança estrutural da obra em estudo os seus elementos assim como todo conjunto deveria ter resistência ao fogo mínima de 30 min., conforme o critério estabelecido na ABNT NBR 15.775:2013 para a categoria de uso.

Sistemas de paredes ou pisos resistentes ao fogo devem manter a capacidade de resistência de todo o conjunto, considerando diferentes caminhos de transferência de calor. Isso deve ser assegurado no projeto, por exemplo, por meio de detalhes construtivos das juntas entre lamelas, paredes e lajes de piso e cobertura, assim como da fixação e proteção dos conectores para manter a estabilidade estrutural.

Como visto até aqui, estudos e ensaios internacionais mostraram que os painéis de CLT atendem ao critério mínimo de $30 \mathrm{~min}$. de resistência ao fogo sem 
proteção, entretanto para garantir a segurança estrutural além do cálculo para o projeto de incêndio baseado no método da seção residual do Eurocode 5, é necessário que o CLT fabricado no Brasil seja avaliado para verificar se as particularidades da fabricação nacional também atendem ao critério mínimo também neste caso.

Para a resistência estrutural verificou-se que, para as aberturas de portas e janelas em elementos que exigem função estrutural, a verga e contraverga foram dispostas com as lamelas externas paralelas à direção da carga, conferindo maior resistência e rigidez nestas áreas, visto que os elementos para o SVV as lamelas externas são dispostas na direção longitudinal (Figura 78).

No estudo de caso apresentado, observou-se uma maior preocupação em relação à questão da deterioração da madeira por agentes biológicos (tratamento dos elementos externos com CCB) e principalmente a deterioração causada pela a umidade (uso de barreiras impermeáveis), justificado pelo clima regional onde o projeto está inserido. A indicação de uso e a retenção mínima do preservante é dada conforme a ABNT NBR 16143:2013 - Preservação de Madeiras - Sistemas de categorias de uso.

Também se verificou que não houve uma preocupação particular quanto às medidas passivas para a segurança contra incêndio do CLT durante o projeto e nenhuma recomendação do fabricante para o sistema e a edificação em questão. A legislação em vigor não exige medidas de proteção contra incêndio para residências menores que $750 \mathrm{~m}^{2}$ e altura inferior a seis metros. Entretanto, a ABNT NBR 15575:2013 exige que, independentemente da área e altura as unidades habitacionais devem atender aos critérios mínimos de desempenho de reação ao fogo de classe III A (cozinhas), II A (espaços comuns), II B fachadas e IV A (ambientes internos) e TRRF de 30 min.( NBR 14432:2001), de acordo com os requisitos estabelecidos para assegurar a vida e evitar condições que podem contribuir para o princípio de incêndio. 
5.9 Recomendações para o projeto de segurança contra incêndio do sistema construtivo de CLT

Com base nas considerações realizadas até aqui, seguem as recomendações para o projeto de segurança contra incêndio do sistema construtivo de CLT:

- Para a resistência ao fogo o CLT deve seguir os parâmetros:

- dados geométricos (por exemplo, tamanhos de seção transversal e disposição);

- taxa de carbonização (de camadas), avaliada com base nas espécies utilizadas;

- densidade característica, expressa em classe de resistência da camada de madeira.

- Para a reação ao fogo verificar a classe de reação ao desempenho do fogo (com base em ensaios para a verificação classificação produção de fumaça e gotículas / partículas flamejantes, se houver) conforme os métodos de ensaios especificados na ABNT NBR 155775 com ou sem tratamento de preservativos contra ataque biológico.

- A reação ao desempenho do fogo do CLT do lamelas de acordo com a EN 14081-1 e as camadas de lamelas dos painéis de acordo com EN 13986.

- O CLT deve ser ensaiado e classificada de acordo com a EN 13501-1.

- Para o cálculo do tempo no projeto de incêndio devem considerar fatores como forças internas e deformações que podem ser induzidas por expansão térmica, e/ou áreas transversais que possam ser reduzidas por carbonização para garantir a resistência dos painéis de CLT;

- Para os painéis de CLT o projeto estrutural em situação de incêndio é realizado pelo método da seção transversal residual após a carbonização de acordo com EN 1995 1-2: 2004. Se o painel tiver função estrutural e:

- não houver risco de queda da camada carbonizada a seção transversal do painel de CLT deve ser considerada como uma única camada; 
- houver risco de queda da camada carbonizada devido à falha na linha de aderência, cada lamela na seção transversal do CLT deve ser considerada como uma camada.

Obs. Métodos de ensaios indicados pela BS EN 16351:2015 e NBR 7190:1997 para delaminação e cisalhamento em temperatura ambiente em relação a aderência entre lamelas podem contribuir para a avaliação do comportamento do adesivo, se comprovado sua resistência em temperatura ambiente pode indicar que não ocorrerá a delaminação porém não será garantido que em temperatura elevada terá o mesmo comportamento. $\mathrm{O}$ uso de adesivos resistentes ao fogo é recomendado.

- Considerar as mesmas propriedades de resistência e rigidez das espécies para as lamelas;

- Elementos de madeira colada, geralmente se comportam da mesma forma que a madeira maciça com o de uso adesivos estruturais, neste sentido podese adotar a mesma taxa de carbonização das espécies usadas nas lamelas;

- Verificar a direção das lamelas externas em relação à carga aplicada (paralela na direção longitudinal da fibra onde há maior resistências aos esforços), para o aumento da resistência estrutural, as lamelas intermediárias dos painéis, em posição ortogonal em relação à carga aplicada, não contribuem para a resistência estrutural.;

- Devido a redução das áreas transversais reduzidas por carbonização levando ao arredondamento dos cantos, o que resulta na exposição das duas faces. Para os elementos de CLT, considerar a taxa de carbonização nominal $\left(\beta_{n}\right)$ para o aumento da resistência entre painéis e do edifício como um todo;

- Verificar os espaçamentos de acordo com a BS EN 16351 entre lamelas (0,2 $\mathrm{mm})$, camadas de lamelas $(0,3 \mathrm{~mm})$ e dimensões dos finger joints $(45 \mathrm{~mm})$, para a resistência ao fogo, pois a ocorrência de cargas irregulares ou carbonização por meio da propagação do calor e gases entre as junções pode levar a diferentes desvios entre os elementos, resultando na falha da seção transversal residual;

- Considerar a resistência das emendas entre camadas zero conforme a BS EN 16351:2015; 
- O uso da taxa de carbonização nominal $\left(\beta_{n}\right)$ também contribui para o aumento da segurança ao fogo do painel, pois considera o espaçamento entre camadas, juntas, conexões etc. no cálculo do projeto de incêndio;

- A resistência ao fogo também pode ser conseguida aumentando-se a espessura do elemento CLT da lamela mais externa mínimo $25 \mathrm{~mm}$, o número de camadas do elemento CLT e do revestimento de proteção correspondente, pois estes métodos contribuem para o atraso da velocidade da carbonização e aumento do tempo da estabilidade da estrutura;

- Uso de adesivos estruturais certificados: adesivos sensíveis a temperaturas elevadas acima de $70^{\circ} \mathrm{C}$. Adesivos elastômeros, não são efetivos sob a ação do fogo;

- Capacidade da prensa para aderência entre as lamelas de 0,6 MPa. Adesivos poliuretanos, ou a base de uréia -formaldeído e resorcinolformaldeído, as pressões recomendadas são, no mínimo de 0,9 Mpa. Estas pressões para a colagem das lamelas podem evitar que ocorra delaminação das camadas;

- Em relação aos adesivos devem-se observar se há liberação de gases tóxicos conforme os métodos de ensaio de reação ao fogo para os painéis de acordo com a sua função de acordo com ABNT NBR 15575;

- Emendas de uma camada não pode coincidir com a das demais camadas. Isso causa perda de resistência do material e evita a propagação do calor e gases mais rápidos entre as camadas do painel;

- Para evitar a passagem de gases quentes através das junções, devem ser utilizadas fitas de vedação geralmente usadas para fins de estanqueidade ao ar, pois estas também podem para impedir a propagação de calor e gases em situação de incêndio. Recomenda-se, também, a aplicação contínua de materiais intumescentes nas juntas entre elementos em ambos os lados e revestimentos e a proteção de áreas expostas da madeira (ver detalhes Figura 46,53,57 e 60);

- Revestimentos não aderidos com espaços vazios entre os componentes de fixação como barrotes ou perfis metálicos devem receber isolamento térmico para que não haja propagação de chamas ou gases entre o revestimento e o painel de CLT (exemplo de detalhe para isolamento da fachada Figura 48); 
- Prever o embutimento dos fixadores e/ou conectores na madeira com profundidade mínima ou proteção deles com materiais incombustíveis. Seguir as disposições para conexões e fixadores de acordo com EN 19951 2: 2004 (Item 5.7.4.7, Figura 61);

- Para garantir a segurança contra incêndio entre os elementos de CLT as instalações devem ser seladas (com selantes, materiais intumescentes, massas, colarinhos/anéis corta fogo etc. ver detalhes (Figuras 53,57 e 60);

- Para tubos metálicos, é essencial o preenchimento de juntas com isolantes térmicos ou materiais intumescentes para evitar a ignição da madeira pela condução do calor através do tubo metálico (ver detalhes Figuras 54 a 60).

- Verificar se há tratamento no painel por preservativo, se esse for caso deve ser documentado para avaliação junto aos ensaios reação ao fogo a combinação do preservativo mais o adesivo, conforme estabelecido na EN 15228: 2009, 4.4.

Além das recomendações acima, há outras disposições que ficaram limitadas neste estudo, devido à necessidade de avaliação por meio de métodos analíticos e de ensaios padronizados como exemplo: o distanciamento seguro entre unidades e seu entorno, pois a partir da determinação da taxa de carbonização do elemento ou dos resultados dos ensaios da reação e resistência ao fogo é possível determinar a distância segura e/ou proteção necessária. 


\section{CONSIDERAÇÕES FINAIS}

A segurança contra incêndio deve fazer parte das decisões do projeto arquitetônico, desde o início do seu processo, pois as soluções adotadas poderão garantir, ou não, a qualidade do projeto, o atendimento aos requisitos de desempenho e de segurança. Por isso, é primordial que projetistas e arquitetos conheçam os conceitos que fundamentam a segurança contra incêndio e as leis, normas e regulamentações vigentes, não só para cumpri-las, mas para que possam contribuir para o desenvolvimento de novas soluções de projeto.

O sistema construtivo de Cross laminated timber ( $C L T)$, criado há mais de vinte anos na Europa, é um sistema constituído de madeira laminada colada com camadas dispostas ortogonalmente entre si e nos últimos anos tem sido tema de várias pesquisas para verificar seu desempenho estrutural, sísmico, acústico e ao fogo e sua durabilidade. Países como Alemanha, Áustria, Reino Unido e Estados Unidos possuem normas técnicas específicas para este sistema.

No Brasil, o CLT é um produto inovador, por definição, pois não possui normas técnicas brasileiras com parâmetros definidos para sua aplicação e, portanto, precisaria submeter-se a avaliação do SiNAT, Sistema Nacional de Avaliação Técnica de Produtos, vinculado ao Programa Brasileiro de Qualidade e Produtividade do Habitat (PBQP-H), do Ministério do Desenvolvimento Regional , para que seja reconhecido pelos órgãos técnicos. Além disso, para se obter financiamento de instituições como a Caixa Econômica Federal é necessário que o produto atenda às diretrizes do PBQP-H e esteja em conformidade com as normas técnicas, assim como a contratação de empresas com certificados de qualidade na área de atuação (BRASIL, 2008). As avaliações dos sistemas inovadores, no âmbito do SiNAT dão respaldo técnico aos gestores e projetistas, além de segurança ao setor da construção e aos usuários.

Para a avaliação técnica é necessária a elaboração de diretrizes que são alinhadas à ABNT NBR 15575:2013 - Edificações Habitacionais - Desempenho (ABNT, 2013), e que se estabeleçam requisitos (exigências qualitativas) e critérios (exigências quantitativas) a serem atendidos pelos subsistemas e o edifício como 
um todo, com base nas exigências, segurança em uso e satisfação do usuário, como também a eficiência, operação e a manutenção das edificações a fim de se obter uma vida útil de projeto (VUP) mínima exigida para o edifício e seus sistemas.

Esta pesquisa foi desenvolvida para propor parâmetros necessários para o sistema construtivo de CLT, com foco na segurança contra incêndio, de acordo com os critérios estabelecidos na ABNT NBR 15.575:2013 para unidades habitacionais isoladas, geminadas, assobradadas e unidades sobrepostas até dois pavimentos. Para tanto realizou-se a revisão bibliográfica de guias, documentos, normas e o estudo de códigos de países que tratam da problemática da segurança contra incêndio para sistemas construtivos de madeira. Além disso, uma breve análise de um estudo de caso do sistema construtivo de CLT foi realizada e demonstrou a necessidade de avaliação dos elementos e do sistema como um todo, para definir critérios específicos do produto nacional, a fim de propor medidas de proteção passiva e evitar eventuais falhas durante a fabricação dos componentes, elementos e execução dos edifícios que se utilizam desse sistema.

\subsection{Sugestões para pesquisas futuras}

Para garantir a segurança ao fogo do sistema de CLT fabricado no Brasil ainda existem muitos fatores que precisam ser estudados e pesquisados, tais como a taxa de carbonização da espécie de conífera a ser utilizada para o elemento, as características do adesivo empregado, a pressão exercida para a aderência entre as lamelas e camadas, a selagem dos elementos para a confecção dos painéis de vedação. Muitos desses fatores fazem parte das particularidades de cada fabricante e de cada país, porém devem ser avaliadas para verificar se atendem as normas técnicas, pois podem interferir diretamente na segurança ao fogo. A falha na aderência na linha de cola devido ao não atendimento mínimo da pressão exercida na prensagem das lamelas, por exemplo, pode contribuir potencialmente no colapso da estrutura.

Para se obter medidas de proteção ao fogo mais efetivas e específicas para o produto nacional, faz-se necessária à sua avaliação por métodos de ensaios padronizados estabelecidos por normas nacionais e internacionais. Com esse intuito, seguem as principais lacunas encontradas, e que podem compor pesquisas 
futuras, a fim de contribuir para melhor caracterização do sistema e a sua disseminação de forma segura:

- Taxa de carbonização para a espécie pinus taeda plantado no Brasil ou de qualquer outra espécie que seja utilizada para a fabricação dos elementos;

- Ensaios de reação ao fogo dos elementos dos painéis fabricados no país sem e com tratamento de preservativos,

- sem e com retardantes de chamas;

- dos elementos do sistema construtivos como um todo;

- dos sistemas de proteção e revestimentos mais utilizados no país;

- com as instalações de serviços e isolamentos, selos corta-fogos etc.;

- Ensaios de resistência ao fogo:

- dos elementos dos painéis fabricados no país sem e com tratamento de preservativos;

- sem e com retardantes de chamas;

- dos elementos do sistema construtivos como um todo;

- dos sistemas de proteção e revestimentos mais utilizados no país;

- com as instalações de serviços e isolamentos, selos corta-fogos etc.;

- Com estrutura acima de dois pavimentos;

- Compatibilização da proteção ao fogo quando há mais de um método construtivo empregado no projeto do edifício;

- Técnicas de reparos e substituições dos elementos quando afetados por princípio de incêndio, que não comprometeu a sua estabilidade estrutural.

\subsection{Conclusão}

Durante a pesquisa notou-se a preocupação de outros países com a questão da segurança contra incêndio, independentemente do material construtivo empregado e da tipologia das edificações. Na maioria dos países estudados, verificou-se que há requisitos a serem adotados mesmo para edifícios residenciais unifamiliares isolados, com medidas de proteção tanto passivas como ativas, como por exemplo, a provisão de mais de uma saída de escape, detectores de fumaça, 
alarmes de incêndio e chuveiros automáticos, uma realidade muito diferente do que se encontra em nosso país.

Além disso, o Brasil não tem um código nacional de segurança contra incêndio e as restrições legais são estabelecidas no âmbito estadual - o que pode implicar no aumento do risco de incêndio onde as exigências são mais brandas.

A introdução do sistema construtivo de CLT no país tem se dado principalmente através dos edifícios residenciais unifamiliares, que não é contemplada pela regulamentação de segurança contra incêndio. Por exemplo, no estado de São Paulo edificações residenciais com área inferior a $750 \mathrm{~m}^{2}$, como casas térreas ou assobradadas (isoladas e não isoladas) e condomínios horizontais (Grupo A-1) são isentas de quaisquer medidas de segurança contra incêndio, mesmo no atualizado Decreto Estadual no 63.911/2018.

A introdução de novos sistemas construtivos com materiais combustíveis como o CLT sem normas técnicas que possam dar suporte e orientação técnica aumenta o potencial risco de incêndio, principalmente para o Grupo A -1 do decreto estadual em vigor.

Mesmo em países onde o CLT foi introduzido e é amplamente utilizado, ainda estão sendo realizados extensivos estudos, pois ainda há lacunas que precisam ser preenchidas e dúvidas a serem elucidadas (delaminação do painel desprotegido, falha do revestimento de proteção, inconsistências na fabricação dos painéis, etc.) e que podem influenciar diretamente no comportamento ao fogo do sistema.

Entretanto, a elaboração de guias técnicos dos fabricantes do CLT, documentos de avaliação técnicas como ETAs e a publicação de normas técnicas tem ajudado o produto a se consagrar no mercado internacional.

No Brasil, por ser um sistema relativamente novo, com menos de dez anos de implantação, ainda há um longo caminho a percorrer para que o sistema se consolide e, principalmente, que atenda todos os requisitos de segurança necessários. 
Esforços estão sendo feitos, com a introdução e revisão de normas técnicas para adequar os produtos, a fim de que os agentes da cadeia da construção civil possam projetar, especificar e executar de forma segura e com qualidade.

A norma ABNT NBR 7190:1997 - Projeto de Estruturas de Madeira, encontrase atualmente em revisão e pretende abordar o cálculo estrutural também para o CLT, no entanto ainda não há nenhuma normativa no país que faça referência ao projeto para as estruturas de madeira considerando a segurança contra incêndio.

As pesquisas acadêmicas e científicas voltam-se à discussão da qualidade do projeto e do desempenho da habitação, premissas necessárias, neste contexto, à identificação e antecipação de problemas que podem decorrer durante o uso e também contribuir para desenvolver ou propor o aprimoramento dos produtos e sistemas construtivos inovadores, além de colaborarem para a retroalimentação do projeto (MENDES, 2018).

Esta pesquisa procurou estudar como é tratada a questão do comportamento ao fogo do CLT em outros países para propor parâmetros que possam contribuir para o projeto e para a avaliação do sistema de CLT nacional como um todo.

O CLT cada vez mais ganha relevância no cenário internacional, e no Brasil pode se tornar um sistema viável no futuro, para todas as tipologias de edificações e até para estruturas mais altas, como se tem visto em outros países. A avaliação técnica e a comprovação do desempenho são imprescindíveis para o CLT ganhar credibilidade e ser amplamente aceito no mercado nacional.

Mas é muito importante alinhar, juntamente com a homologação do CLT ou de qualquer outro produto inovador, propostas de políticas públicas que envolvam todos os grupos de uso e ocupação, para a segurança contra incêndio evoluir no país, a fim de garantir a qualidade, segurança do patrimônio, do seu entorno e principalmente a vida usuário. 


\section{REFERÊNCIAS BIBLIOGRÁFICAS}

ABCB. National Code Construction (NCC). Disponível em: $<$ https://ncc.abcb.gov.au/>. Acesso em: 27 set. 2018.

ABU, A.K; BUCHANAN, A. H. Structural design for fire safety .Second edition. Chichester, West Sussex, United Kingdom: John Wiley \& Sons Inc., 2017.

AECWEB. Eletrodutos rígidos, corrugados e flexíveis planos: saiba como especificar. Disponível em: <https://www.aecweb.com.br/cont/m/rev/eletrodutosrigidos-flexiveis-corrugados-e-flexiveis-planos-saiba-especificar $\begin{array}{lllll}7274 & 10 & 0\end{array}>$. Revista digital. Material e soluções. Acesso em: out. 2019.

AGÊNCIA BRASILEIRA DE DESENVOLVIMENTO INDUSTRIAL. ABDI. Manual da construção industrializada. Brasília, DF, 2015. Disponível em: < https://www.abdi.com.br/>. Acesso em: jul. 2018.

AGUILAR, D.F. Combustibilidade e tratamento ignífugo da madeira. Dissertação (Mestrado) - Escola de Engenharia de São Carlos. Universidade de São Paulo. São Carlos, 1986.

AMERICAN SOCIETY FOR TEST AND MATERIALS. ASTM E119-08a, Standard test Methods for fire tests of building construction and materials. West Conshohocken, PA, 2008.

AMERICAN SOCIETY FOR TEST AND MATERIALS. ASTM E662: Standard test method for specific optical Density of smoke generated by solid materials. [S.I] West Conshohocken, PA, 2018.

ANSI/APA - The Engineered Wood Association. Standard for Performance-Rated Cross-Laminated PRG 320:2018. ANSI/ APA. Tacoma, WA, 2012.

APPROVED DOCUMENT B. Fire safety. Ministry of Housing, Communities \& Local Government. United Kingdom. Acesso em: 09 outubro 2018.

ASSOCIAÇÃO BRASILEIRA DE NORMAS TÉCNICAS (ABNT). NBR 9442: Materiais de construção - Determinação do índice de propagação superficial de chama pelo método do painel radiante. Rio de Janeiro: ABNT, 1986.

NBR 10636: Paredes divisórias sem função estrutural - Determinação de resistência ao fogo - Método de ensaio. Rio de Janeiro: ABNT, 1989.

NBR 6479: Portas e vedadores - Determinação da resistência ao fogo. Rio de Janeiro: ABNT, 1992.

. NBR 7190: Projeto de estruturas de madeira. Rio de Janeiro: ABNT, 1997.

$2001 a$. NBR 9077: Saídas de emergência em edifícios. Rio de Janeiro: ABNT, 
NBR 14432: Exigências de resistência ao fogo de elementos construtivos de edificações - Procedimento. Rio de Janeiro: ABNT, 2001b.

. NBR 5628: Componentes construtivos estruturais - Determinação de resistência ao fogo. Rio de Janeiro: ABNT, 2001c.

. NBR 5628: Componentes construtivos estruturais - Determinação da resistência ao fogo. Rio de Janeiro: ABNT, 2001d.

NBR 5410: instalações elétricas de baixa tensão. Rio de Janeiro: ABNT, 2004.

NBR 17240: Sistemas de detecção e alarme de incêndio - Projeto e instalação, comissionamento e manutenção de sistemas de detecção e alarme de incêndio - Requisitos. Rio de Janeiro: ABNT, 2010.

NBR 15523: Inspeção de rede de distribuição interna a para gases combustíveis em instalações residenciais e instalação de aparelhos de gás para uso residencial - Procedimento. Rio de Janeiro: ABNT, 2011.

NBR15526: Redes de distribuição interna a para gases combustíveis em instalações residenciais - Projeto e execução. Rio de Janeiro: ABNT, 2012.

. NBR 8660: Ensaio de reação ao fogo em pisos - Determinação do comportamento com relação à queima utilizando uma fonte radiante de calor. Rio de Janeiro: ABNT, 2013 a.

. NBR 15575: Edificações habitacionais - Desempenho 6 partes. Rio de Janeiro: ABNT, 2013 b.

NBR 5419: Proteção contra descargas atmosféricas - Parte 1: Princípios gerais. Rio de Janeiro: ABNT, 2015.

. NBR 16626: Classificação da reação ao fogo de produtos de construção. Rio de Janeiro: ABNT, 2017. ABNT, 2019.

NBR 13523: Central de gás liquefeito de petróleo - GLP. Rio de Janeiro:

BERTO, A. F. Medidas de Proteção Contra Incêndio: aspectos fundamentais a serem considerados no projeto dos edifícios. Dissertação (Mestrado) - Faculdade de Arquitetura e Urbanismo- Universidade de São Paulo. São Paulo: [s.n.], 1991.

BRANCO, J. M.; LOURENÇO, P. B. Dos abrigos da pré-história aos edifícios de madeira do século XXI. RepositóriUM - Universidade do Minho, Guimarães. Lisboa, 2012. Disponível em: < https://repositorium.sdum.uminho.pt/bitstream/1822/26503/1/Lourenco Branco.pdf > Acesso julho 2018.

BRANDON, D.; ÖSTMAN, B. Fire Safety Challenges of Tall Wood Buildings. Phase 2: Task 1 - Literature Review. SP Technical Institute of Sweden. Borås set, 2016. 
BRASIL. Ministério das cidades. Diretriz SiNAT no.5 - Sistemas construtivos estruturados em peças de madeira maciça serradas com fechamentos em chapas delgadas (sistema leve tipo "Light Wood Framing"). Brasília, D.F, set. 2011.

BRASIL. Ministério do meio ambiente. Empregos no setor florestal. Serviço florestal brasileiro. Brasília, DF. Disponível em: $<$ http://www.florestal.gov.br/component/k2/item/317-julho-programa-1-empregosno-setor-florestal >. Acesso em: jun. 2017 a.

BRASIL. Ministério das cidades. Programa Brasileiro da Qualidade e Produtividade do Habitat (PBQP-H) - Sistema Nacional de Avaliação Técnica (SiNAT). Brasília, DF. Disponível em: <http://pbqp-h.cidades.gov.br/projetos sinat.php >. Acesso em: abr. 2017b.

BRITISH STANDARD INSTITUTION. BS 476-6: Fire Tests on Buildings materials and structures. London: UK, 1989.

.BS 476-7: Fire Tests on Buildings materials and structures - Method of to determine the classification of the surface spread of flame of products. London: UK, 1997.

.BS EN ISO 11925-2: Reaction to fire test. Ignitability of products subjected to direct impingement of flame. Single-flame source test. London: UK, 2010.

.BS EN 13823:2010+A1:2014: Reaction to fire tests for building products. Building products excluding floorings exposed to the thermal attack by a single burning item. London: UK, 2014.

.BS EN 16351: Timber structures. Cross laminated timber. Requirements. London: UK, 2015 a.

.BS EN 13986:2004+A1:2015: Wood-based panels for use in construction. Characteristics, evaluation of conformity and marking. London: UK, $2015 \mathrm{~b}$.

.BS EN 301: Adhesives, phenolic and aminoplastic, for load-bearing timber structures. Classification and performance requirements. London: UK, 2017.

.BS EN 15425: Adhesives. One component polyurethane (PUR) for loadbearing timber structures. Classification and performance requirement. London: UK, 2017.

BS EN 13501-1: Fire classification of construction products and building elements Classification using data from reaction to fire tests. London: UK, 2018.

BS EN 14081-1:2016+A1:2019: Timber structures. Strength graded structural timber with rectangular cross section General requirements. London: UK, 2019 b.

BUCHANAN, A.H. Burning issues in timber engineering. In: Pacific Timber. Conference; Rotorua, New Zealand; mar. 1999. 
BUCHANAN, A. H. et al. Fire Safety of CLT Buildings in New Zealand and Australia. Wood and Fiber Science, 2018. Wood and Fiber Science, 50(Special Issue), 2018, pp. 96-101 by the Society of Wood Science and Technology

BUCHANAN, A. H. Structural Design Fire Safety. Second edition. Chichester, West Sussex, United Kingdom: John Wiley \& Sons Inc., 2017.

CANADIAN WOOD COUNCIL. CWC. Fire Safety in Buildings. ccw.ca, 1996. Disponível em: <http://cwc.ca/wp-content/uploads/publications-FireSafetyDesigns.pdf $>$. Acesso em 10 de jun. de 2018.

CASTILHO, A. A. H. Escritório de arquitetura. Valinhos, SP, dez., 2019. il. color.

CORPO DE BOMBEIROS DA POLÍCIA MILITAR DO ESTADO DE SÃO PAULO. Instrução Técnica Nº8 - Segurança estrutural contra incêndio. São Paulo. 2018.

CORPO DE BOMBEIROS DA POLÍCIA MILITAR DO ESTADO DE SÃO PAULO. Instrução Técnica $\mathbf{N}^{\circ} 02$ - Conceitos básicos de segurança contra incêndio. São Paulo. 2019.

CORPO DE BOMBEIROS DA POLÍCIA MILITAR DO ESTADO DE SÃO PAULO. Instrução Técnica $\mathbf{N}^{\circ} 14$ - Carga de incêndio nas edificações e áreas de risco. São Paulo. 2018.

CBI - MINISTRY OF FOREGIN AFFAIRS. Exporting cross laminated timber (CLT) to Western Europe. Disponível em: < https://www.cbi.eu/marketinformation/timber-products/cross-laminated-timber/europe/ >. Acesso em 20 ago. 2018. il.color.

COMPANHIA ESTADUAL DE TECNOLOGIA DE SANEAMENTO BÁSICO E CONTROLE DE POLUIÇÃO DAS ÁGUAS. CETESB. Disponível em: < https://sistemasinter.cetesb.sp.gov.br/produtos/ficha completa1.asp?consulta=DII SOCIANATO\%20DE\%20DIFENILMETANO> Acesso em out. de 2019.

COSTA, A. A. P. Construção de edifícios com Cross laminated timber (CLT). Dissertação (Mestrado). Faculdade de Engenharia. Universidade do Porto. Porto, 2013.

CROSSLAM. Sobre o CLT, 2016. Disponível em: < http://crosslam.com.br/ >. Acesso em abr. 2018.

DAGENAIS, C. FPInnovantions. CHAPTER 8 - Fire performance of crosslaminated timber assemblies. Revised version. Ontario, jul. 2014.

EMBERLEY, R. L. Fundamentals for the Fire Design of Cross Laminated Timber Buildings. The University of Queensland. Australia, 2017.

EUROPEAN ASSESSMENT DOCUMENTS - EAD 130005-00-0304 Solid Wood Slab Element to be Used as a Structural Element in Buildings.mar.2015. 
EUROPEAN TECHNICAL APPROVAL. ETA - 06/138 - Solid wood slab element to be used as structural elements in buildings Edition march 2015. With validity from 10.09.2012 to 09.09.2017. Viena, 2017 Disponível em: <http://www.klhuk.com/media/9379/klh eta certificate en.pdf>. Acesso: out.2019.

EUROPEAN COMMITTEE FOR STANDARDISATION. EN 1995-1-1: Eurocode 5: Design of timber structures - Part 1-1: General - Common rules and rules for buildings. CEN. 2004.

FIGUEROA, M. J. M.; MOARES, P. D. D. Comportamento da madeira a temperaturas elevadas. Ambiente construído, Florianópolis, nov. 2009.

FIRE Safety in Buildings. ccw.ca, 1996. Disponível em: <http://cwc.ca/wpcontent/uploads/publications-FireSafetyDesign-s.pdf>. Acesso em: 10 jun. 2018.

FONTANA, M.; FAVRE, J.P.; FETZ, C. A survey of 40,000 building fires in Switzerland. Fire Safety Journal, 32. mar. 1999.137-158.

FORTE. Disponível em:< https://www.victoriaharbour.com.au/live-here/ >. Acesso em: maio 2018. il.color.

FRANGI, A. et al. Experimental analysis of cross-laminated timber panels in fire. Fire Safety Journal. 44. 1078-1087. 10.1016/j.firesaf.2009.07.007. Acesso em: maio de 2019

INTERNATIONAL BULDING CODE - IBC 2015.Disponivel em: < https://codes.iccsafe.org/content/IBC2015/chapter-7-fire-and-smoke-protectionfeatures >. Acesso em: 18 out. 2018.

INTERNATIONAL STANDARDIZATION ORGANIZATION. ISO/TR 3814: Tests to measuring reaction to fire of buildings materials - Their development and application Geneva, 1989.

.ISO 834: Fire-resistance tests - Elements of building construction - Part 1: General requirements, Geneva, 1999.

. ISO 13823: Reaction to fire test for building products. Building products excluding floorings exposed to the thermal attack by a single burning item. Geneva, 2002. 2008 a.

ISO 540: Hard coal and coke - Determination of ash fusibility. Geneva,

ISO 6944-1: Fire containment - Elements of building construction - Part 1: Ventilation ducts. Geneva, 2008 b. Geneva, 2010.

ISO 1182: Reaction to fire tests for products - Non-combustibility test

ISO 11925-2: Reaction to fire tests - Ignitability of products subjected to direct impingement of flame - Part 2: Single-flame source test. Geneva, 2010. 
.ISO 5660.1: Reaction-to-fire tests - Heat release, smoke production and mass loss rate - Part 1: Heat release rate (cone calorimeter method) and smoke production rate (dynamic measurement). Geneva, 2015.

. ISO 9705: Reaction to fire tests - Room corner test for wall and ceiling lining products - Part 1: Test method for a small room configuration. Geneva, 2016.

KLIPPEL, M; JUST, A. Guidance on Fire design of CLT including best practice. COST Action FP1404, Zürich, Switzerland, 2001

LEGISLATION GOVERNMENT THE UNITED KINGDOM. The Built Regulatio,2010. (Lei Complementar $N^{\circ}$ 1.257, 06 de janeiro de 2015, regulamentado pelo Decreto № 63.911 de 10 de dez. 2018).

LEERS WEINZAPFEL ASSOCIATES. University of Arkansas Adohi Hall (Residential, Living Learning). Disponível em: <https://www.lwa-architects.com/project/university-arkansasstadium-drive-residence-halls/ $>$ FAYETTEVILLE, AR. fall. 2019. Acesso em nov.2019.

MARTINI, S. Disponível em: <https://www.montana.com.br/noticias/Maisnoticias/Madeira-engenheirada >. Acesso jul. 2018.

MENDES, M. C. M. A percepção dos moradores sobre o uso dos sistemas construtivos inovadores em habitações: uma contribuição da avaliação pósocupação. Tese (Doutorado) - Instituto de Arquitetura e Urbanismo, Universidade de São Paulo. São Carlos, 2018.

MG-ARCHITETURE. Australias largest commercial timber building in Sydney. mg-architecture.ca. Disponível em: <https://inhabitat.com/australias-largestcommercial-timber-building-rises-in-sydney/> Acesso em: junho 2018.

MITIDIERI, M. L. Verificação do comportamento frente ao fogo de materiais. NUTAU Tecnologia e desenvolvimento. São Paulo: [s.n.]. 2000.

MITIDIERI, M. L. A segurança contra incêndio no Brasil Cap.V - O comportamento dos materiais e componentes construtivos diante do fogo reação ao fogo. São Paulo: Projeto, 2008. 68 p.

MUNIS, R. A. et al. Avaliação da Resistência à Compressão Paralela as Fibras de Painéis de CLT (Cross Laminated Timber) de Pinus elliottii. XXVIII Congresso de Iniciação Científica Campus Experimental de Itapeva, Engenharia Industrial Madeireira, UNESP, 2016.

NATIONAL FIRE PROTECTION ASSOCIATION NFPA 13R: Standard For the installation of sprinkler systems in low-rise residential occupancies. Quincy, MA, 2016 Edition. 
NATIONAL FIRE PROTECTION ASSOCIATION - NFPA 5000: Building Construction and safety code. Quincy, MA. Disponível em: <https://catalog.nfpa.org/ >. Acesso em: 15 out. 2018.

NATIONAL FIRE PROTECTION ASSOCIATION. NFPA.org. Quincy, MA, 2018. Disponível em: <https://nfpa.org/ >. Acesso em: 18 out. 2018.

NIELSEN, P. C.; OLESEN, F. B. Tensile Strength of Finger Joints at Elevated Temperatures. Report, No. 8205. Institute of Building Technology Structural Engineering, Aalborg University Center, 1982.

OLIVEIRA, G. L. Cross Laminated (CLT) no Brasil: processo construtivo e desempenho. Recomendações para 0 processo do projeto arquitetônico. Dissertação (Mestrado) - Faculdade de Arquitetura e Urbanismo, Universidade de são Paulo. São Paulo, 2018.

ONO, R.; VALENTIN, M. V.; VENEZIA, A. P. P. G. A segurança contra incêndio no Brasil - Cap. IX Arquitetura e urbanismo. São Paulo: Projeto, 2008.

PAGE, T. S. A. D. The durability of manufactured structural buildings materials, 47th IRG. Annual Meeting. Lisboa: [s.n].2016.

PAGNOCENCELLI, L. et al. Acoustic performance of cross-laminated timber system $(C L T)$ : in situ. Measurements of airborne and impact sound insulation for different configurations. 40th IAHS World Congress on Housing: Sustainable Housing Funchal:[s.n].2014.

PASSARELLI, R. N. Cross laminated timber: diretrizes para projeto de painel maciço em madeira no Estado de São Paulo. Dissertação (Mestrado). Instituto de Arquitetura e Urbanismo - Universidade de São Paulo. São Carlos, p. 174. 2013.

PEREIRA, Marcos Cesar de Moraes. Metodologia para estudo da caracterização estrutural de painéis de madeira laminada colada cruzada. 2014. Dissertação (Mestrado em Desenvolvimento, Caracterização e Aplicação de Materiais) - Escola de Engenharia de São Carlos, Universidade de São Paulo, São Carlos, 2015. doi:10.11606/D.18.2015.tde-07052015-084252. Acesso dez. 2019.

PINTO, E. M. Proteção contra incêndio para habitações em madeira. Dissertação (Mestrado). Escola de engenharia de São Carlos - Universidade de São Paulo. São Carlos, p. 143. 2001.

PINTO, E. M.; JUNIOR, C. C. Comportamento da madeira exposta ao fogo. Remad, São Paulo, n.128, ago. 2011.

PINTO, Edna Moura. Determinação de um modelo para a taxa de carbonização transversal a grã para a madeira de E. citriodora e E. grandis. 2005. Tese (Doutorado em Ciência e Engenharia de Materiais) - Ciência e Engenharia de Materiais, Universidade de São Paulo, São Carlos, 2005.

POPOVSKY, M. et al. Determination of seismic performance factor for CLT shear wall systems. World Conference on Timber Engineering. Viena: [s.n], 2016. 
REMADE. Madeira: Painéis - Características e Aplicações. Disponível em $<$ http://www.remade.com.br/madeiras/19/paineis/caracteristicas-e-aplicacoes $>$.

Acesso abr. 2019.

RETHINK WOOD. Disponível

em:<https://www.awc.org/pdf/education/des/ReThinkMag-DES610A-

Mass TimberinNorthAmerica-161031.pdf >Acesso ago. 2019. il.color.

SEITO, A. I. et al. A Segurança Contra Incêndio no Brasil. São Paulo: Projeto Editora, 2008.

SHEPPARD ROBSON. Open Academy, Norwich A CLT shaped to focus on its community. Disponível

em: $<$ https://www.sheppardrobson.com/architecture/view/the-open-academy > Acesso em: jun. 2018. il.color.

SILVA,C.A; CHIRINÉIA, M. L. B.; BARROS, MÁRCIA M.S. Cross Laminated Timber (CLT): Uma tecnologia viável no Brasil. ENTAC XVI - Encontro Nacional de Tecnologia. São Paulo: [s.n.].2016.

SONIA. Understanding House Framing. Disponível em: < https://extremehowto.com/understanding-house-framing/?page=all>.Acesso em: jun. 2018.

STANDARD AUSTRALIAN. AS 1530.4: Methods for Fire Tests on Building Materials, Components and Structures - Fire-resistance test of elements of construction, 2014

STANDARD AUSTRALIAN. AS 5637.1: Determination of fire hazard properties, Part 1: Wall and ceiling linings; Status: Current; Publish Date: 2015.

SU, J. e MURADORI, S. Fire Demonstration: Cross-Laminated Timber Stair/Elevator Shaft. Technical Report. 10.4224/21277597 jan.2015

TEIBINGER, M; MATZINGER, I. Construction with Cross- Laminated Timber in multi-storey buildings. Focus on building physics. Guidelines. Viena, fev. 2013.

TOMASI, R; SMITH, I. Experimental Characterization of Monotonic and Cyclic Loading Responses of CLT Panel-To-Foudantion Angle Bracket Connections. Journal of Materials in Civil Engineering. Vol. 27. issue 6. Reston, VA, jun. 2015.

VALLE, A. et al. Estruturas de madeiras. Apostila versão 2. Universidade Federal de Santa Catarina Centro Tecnológico - Departamento de Engenharia Civil. Florianópolis, 2015.

VARGAS, M. R.; ONO, R.; SILVA, V. E. P. Prevenção contra Incêndio no Projeto de Arquitetura (Construção com Aço). Rio de Janeiro: IABr/CBCA, 2010.

UNDERWRITERS LABORATORIES OF CANADA. ULS 101: Standard Methods of Fire Endurance Testes of Buildings and Material. CAN/ULC. Toronto, 2104. 
XLAM. Plant and Food Research. xlam.co.nz. Disponível em: < https://www.xlam.co.nz/case-studies/plant-and-food-research.html >. Acesso em: maio 2018. il. color.

WAUGH THISTLETON ARCHITECTS. Murray Grove. The original timber tower. $<$ http://waughthistleton.com/murray-grove/ >. Acesso em: jun. 2018. il. color.

ZENID, G. J. Madeiras para móveis e construção civil. São Paulo: IPT/SCTDE, 2002. CD-ROM (IPT. Publicação, 2779).

Referências digitais:

https://www.binderholz.com/

https://www.ckc.com.br/

https://www.henkel.com.br/

https://www.klh.at/

http://www.klhuk.com/

https://www.rothoblaas.pt/

https://www.storaenso.com/ 